\title{
The Politics of Austerity and Social Citizenship Rights: A Case Study of the Impact of the 2008 Financial Crisis on the Welfare State in Portugal
}

\author{
by
}

\section{Filipe Duarte}

\begin{abstract}
A thesis submitted to the Faculty of Graduate and
Postdoctoral Affairs in partial fulfilment of the requirements for the degree of
\end{abstract}

Doctor of Philosophy

In

Social Work

Carleton University

Ottawa, Ontario

Canada

(C) 2018

Filipe Duarte 


\section{Abstract}

This dissertation focuses on the process and degree of welfare retrenchment under the paradigm of austerity following the 2008 financial crisis. It provides a detailed account of the austerity measures on cash benefits of social citizenship rights - minimum income, unemployment insurance and old-age pensions - adopted in Portugal between 2010 and 2014. This dissertation also offers a comprehensive framework for defining the rights of social citizenship in $21^{\text {st }}$ century capitalist market economies derived from two theoretical approaches: Marshall's social citizenship framework and Esping-Andersen's approach on welfare provision and redistribution. The author puts forward the thesis that the austerity measures adopted in Portugal between 2010 and 2014 have considerably eroded the degree of decommodification of the public welfare provision of cash benefits which are part of social citizenship rights in Portugal. It is argued that the reduction in public spending and the cumulative effect of multiple policy changes in exchange for a $€ 78$ billion financial bailout were very damaging to the entitlements of social protection. Furthermore, the dissertation also confirms that EU policies of balanced budgets that constitutionalize lower public deficits undermine the constitutional principles of social citizenship fulfillment between the state and its citizens. The austerity measures, either proposed or fully adopted by the Portuguese authorities between 2010 and 2014, were based on certain ideological assumptions and economic beliefs that do not serve the interests of the most vulnerable and working-class people. The recommendations explore both directions for policy, as well as for future research. A more egalitarian redistribution of cash benefits for citizens from European member states within the Eurozone, like Portugal, is being proposed because questions of public debt, sustainability of public expenditure, inflation, budgetary consolidation and unemployment, will continue to arise within the European Union. 


\section{Acknowledgements}

There are so many people without whom completing this thesis would have been impossible. I am eternally grateful to them all.

In 2012 I moved to Canada from Portugal to pursue a PhD in Social Work at Carleton University because I was interested in the structural and radical social work milieu, pioneered at Carleton's School of Social Work in the 1970s by Maurice Moreau, Allan Moscovitch, Helen Levine, Roland Lecomte, Peter Findlay, Peter Leonard, and continued by Colleen Lundy, Rashmi Luther and Steven Hick, among others.

I would like to thank Colleen Lundy for giving me opportunity to undertake and complete my doctoral studies at Carleton's School of Social Work. I owe it all to you. Many thanks! I will carry on the School's legacy.

I am also grateful to my doctoral co-supervisors Allan Moscovitch and Hugh Shewell, who allowed me to take on this project. Throughout the long process of framing, researching, writing, and rewriting, they have offered invaluable support and careful criticism to craft this research. I am deeply grateful to them for such encouragement, assistance and excellent example throughout my $\mathrm{PhD}$ journey. It has been an honor to be their $\mathrm{PhD}$ student.

I also offer my deep gratitude to my other committee member, Achim Hurrelmann, who has provided me insightful ideas and contributions. Achim was always a careful listener and a wise advisor to help me better grasp my ideas which made my dissertation immeasurably better. I feel very fortunate to have him on my $\mathrm{PhD}$ committee. 
My recognition and gratitude also goes to Carleton's School of Social Work staff, in particularly to the graduate administrators Stephanie Mulville and Sue Brady. Stephanie and Sue provided me immensurable support throughout these last six years. From the beginning, they contributed immensely to my personal and academic success. I am deeply thankful for their support.

I would like to make a special mention of Ginette Thomas and Prince Owusu, both, two special friends and fellow PhD students. Ginette, you have been on this journey with me since the beginning in 2012. There are no words to express my gratitude to you - for everything. I extend my joy and gratitude to all of the Thomas family. My friend Prince, I very much appreciate your friendship and support. Thank you.

I also would like to particular thank my Ottawa friends Agathe Rhéaume, Rashmi Luther, John Macdonald, Maria Fátima de Sousa, Victor da Rosa, Gustavo Frederico and Joana Pimentel for their friendship and support countless of times. Thank you.

And finally, I want to thank all my family for all their love and encouragement. Patricia and Diogo, I love you both, and appreciate your support more than ever. I dedicate this project to you for encouraging me and helping me to keep going when it felt too hard, thank you. There will never be enough words to express my thanks and my love for you. I feel so privileged and grateful for the relationship we have. 
"To be radical is to grasp the root of the matter."

Karl Marx, Critique of Hegel's Philosophy of Right (1843) 


\section{Table of contents}

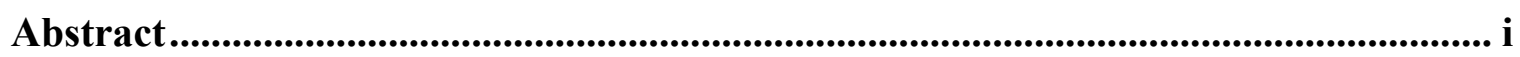

Acknowledgements...................................................................................................................... ii

Table of Contents ...........................................................................................................................

List of Acronyms and Abbreviations................................................................................. viii

List of Tables .................................................................................................................................... xi

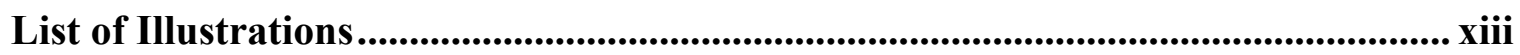

Introduction ..........................................................................................................................................1

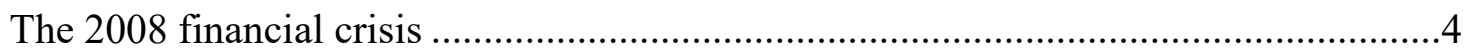

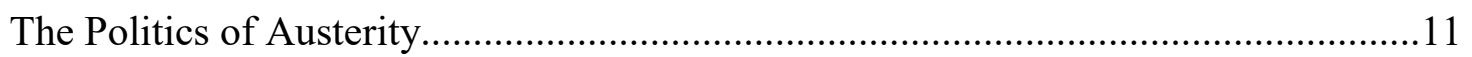

Austerity in Portugal (2010-2014) ………………............................................13

Social Work Responds to the Financial Crisis ............................................................15

How to Understand What Happened ......................................................................17

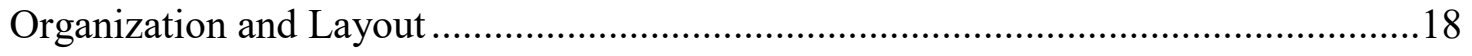

Chapter I: Theoretical Framework ...........................................................................................20

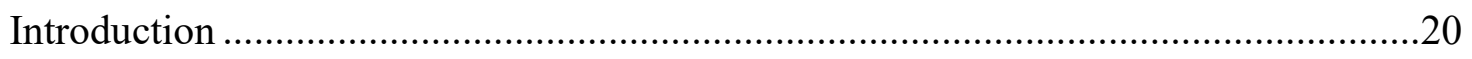

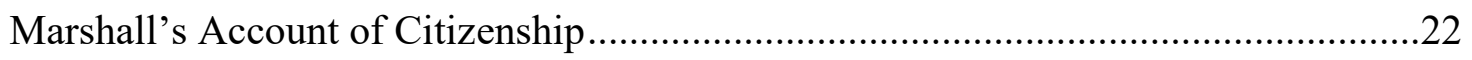

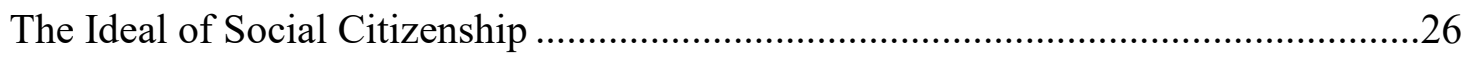

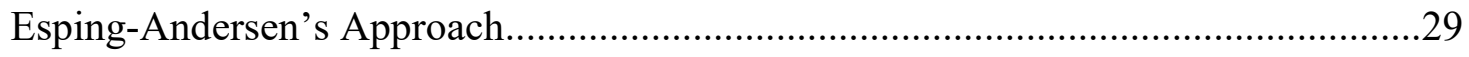

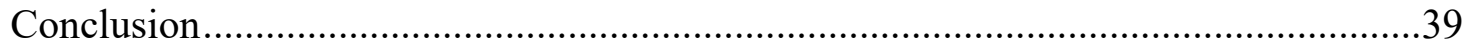

Chapter II: The Nature of Social Citizenship Rights: Definition and Reconfiguration

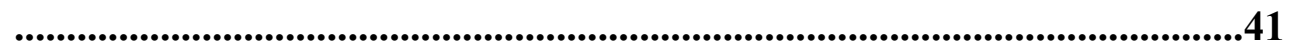

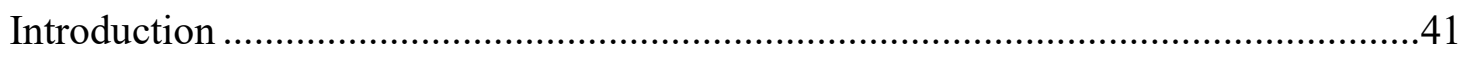

The Emergence of Social Citizenship Rights ............................................................42 
The Nature of Social Citizenship Rights ............................................................43

The Public Provision of Social Citizenship Rights ................................................49

The Reconfiguration of Social Citizenship Rights .............................................54

Measuring the Retrenchment of Social Citizenship Rights.....................................57

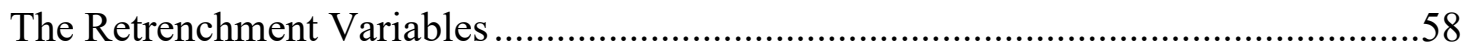

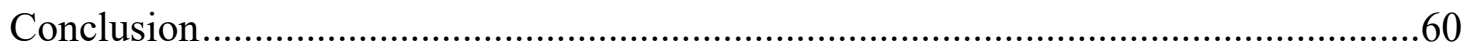

Chapter III: The Rise of the Portuguese Welfare State ..........................................62

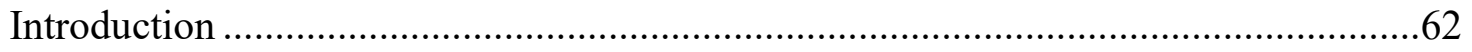

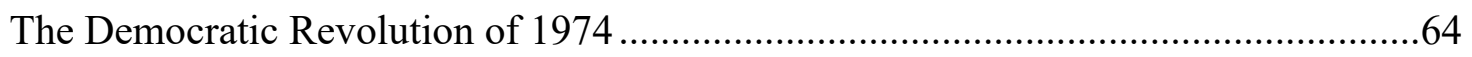

The Design of the Portuguese Welfare State.......................................................67

The 1980s: The Neo-liberalization of the Portuguese Welfare State..........................74

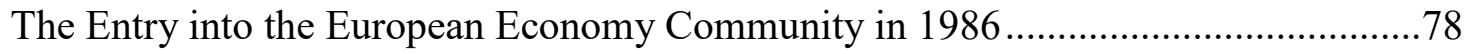

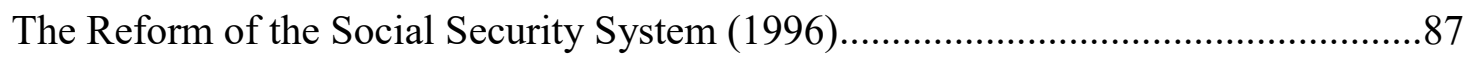

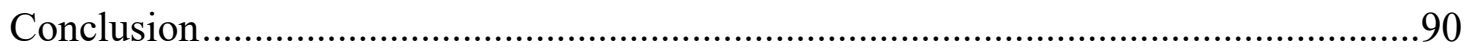

Chapter IV: Europe's Budgetary Rules ............................................................................92

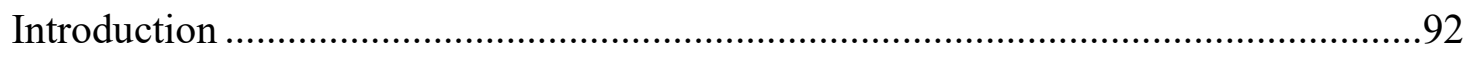

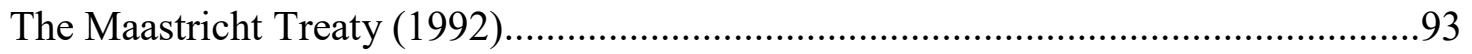

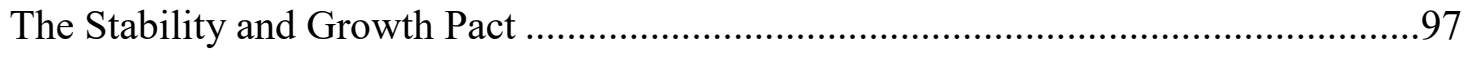

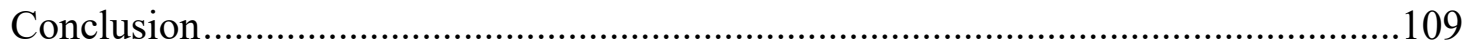

Chapter V: The Retrenchment of Social Citizenship Rights in Portugal under the Paradigm of Austerity (2008-2014) ..................................................111

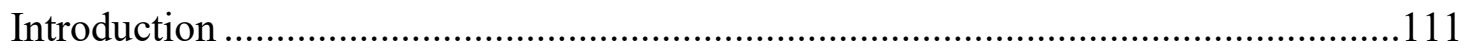

The Prelude of Portugal's Financial Crisis (2008-2009).......................................111

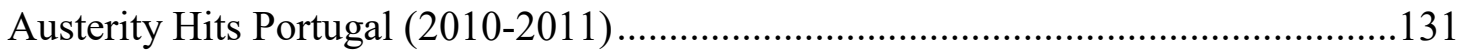

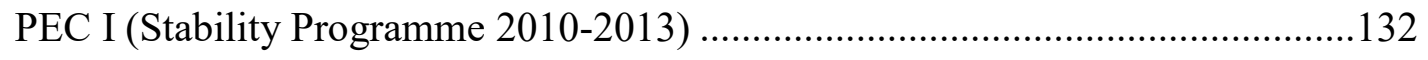




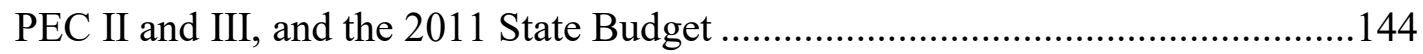

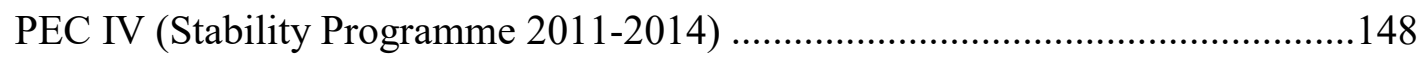

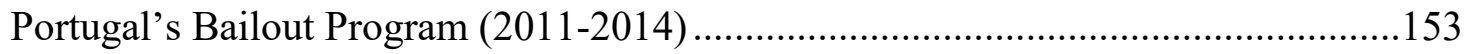

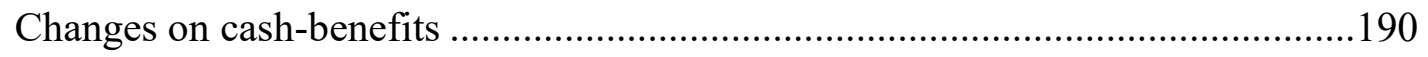

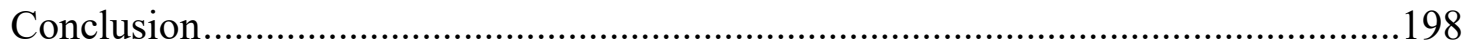

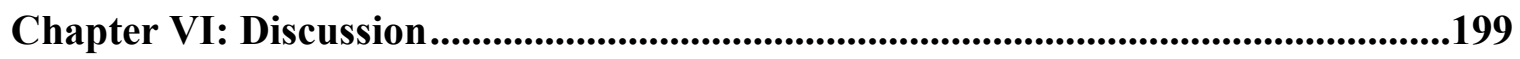

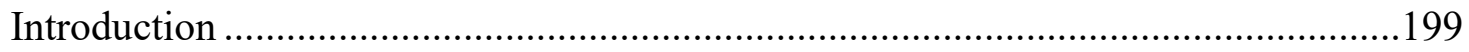

Interpretation of Findings: Revisiting Research Questions.................................200

Examining Key Findings with Reference to the Literature....................................213

The 2008 Financial Crisis in Context ...............................................................213

The Political Economy of Austerity in Portugal ...............................................2. 215

The Retrenchment of Social Citizenship Rights Under Austerity.......................217

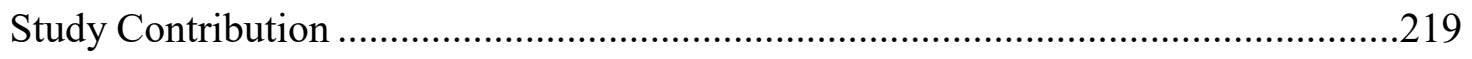

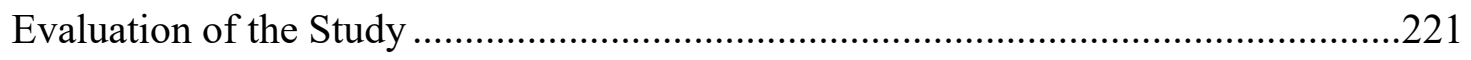

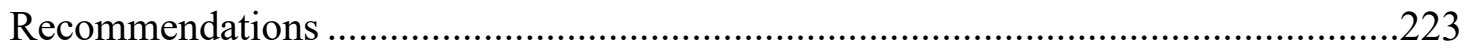

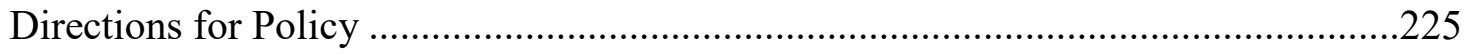

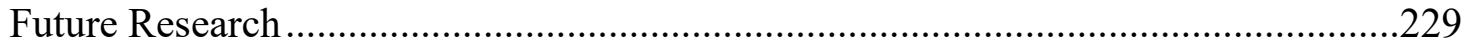

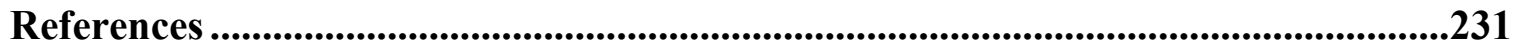




\title{
List of acronyms and abbreviations
}

\author{
ADSE Public Health Insurance System for Civil Servants \\ AR Assembleia da República (Portuguese Parliament) \\ BPN Portuguese Business Bank (Banco Português de Negócios) \\ CGA Public Special Pension Scheme for Civil Servantes (Caixa Geral de \\ Aposentações) \\ CoE Council of Europe \\ CSI Guaranteed Income Supplement (Complemento Solidário para \\ Idosos) \\ DRE Electronic Edition of Portugal's Official Journal (Diário da \\ República Eletrónico) \\ ECB European Central Bank \\ ECOFIN The Economic and Financial Affairs Council \\ EEC European Economic Community \\ EESC European Economic and Social Committee \\ EFSF European Financial Stability Facility \\ EFSM European Financial Stabilisation Mechanism \\ EFTA European Free Trade Association \\ ELA European Labour Authority \\ EMU Economic and Monetary Union \\ ESF European Social Fund \\ ESM European Stability Mechanism \\ ESPN European Social Policy Network \\ EU European Union \\ GDP Gross Domestic Product \\ GMI Guaranteed Minimum Income (Rendimento Social de Inserção) \\ GovPT Government of Portugal \\ ICESCR International Covenant of Economic, Social and Cultural Rights \\ ILO International Labour Organization
}


IMF International Monetary Fund

ISS Instituto de Segurança Social (Social Security Institute)

MFA Armed Forces Movement (Movimento das Forças Armadas)

MEFP Memorandum of Economic and Financial Policies

MoU Memorandum of Understanding

MTOs Medium-Term Budgetary Objectives

NGOs Non-Governmental Organizations

NRP National Reform Program

OECD Organisation for Economic Co-operation and Development

PAYGO Pay-As-You-Go System

PEC Programa de Estabilidade e Crescimento (Stability Programme)

PIDE Political Police (until 1974)

PREC Processo Revolucionário em Curso (Ongoing Revolutionary Process)

PS Partido Socialista (Socialist Party)

PSD Partido Social Democrata (Social-Democratic Party)

RMG Rendimento Mínimo Garantido (Guaranteed Minimum Income)

RSI Rendimento Social de Inserção (Guaranteed Minimum Income)

SDR Special Drawing Rights (IMF Currency)

SEA Single European Act

SGP Stability and Growth Pact

SNS Sistema Nacional de Saúde (National Health Care System)

SP Stability Programme

TC Tribunal Constitutional (Constitutional Court)

TEU Treaty on the European Union

TFEU Treaty on the Functioning of the European Union

TSCG Treaty on Stability, Coordination and Governance in the Economic and Monetary Union

UDHR Universal Declaration of Human Rights

UK United Kingdom

UN United Nations 
US United States (of America)

VAT Value Added Tax (IVA in Portuguese)

WWII World War II 


\section{List of tables}

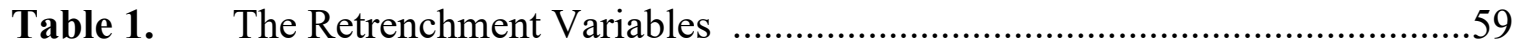

Table 2. Portugal's Public Social Spending (1973-1979)........................................74

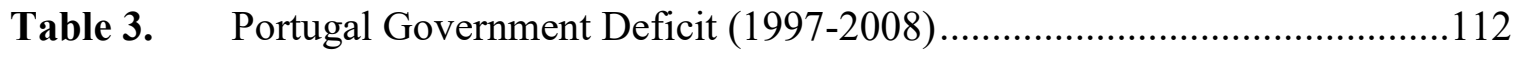

Table 4. Portugal General Government Debt (1997-2008) ....................................113

Table 5. Portugal Unemployment Rate (1998-2008) ...........................................114

Table 6. Portugal Public Social Spending (1997-2008).........................................115

Table 7. Portugal's General Government Spending (1997-2008) ...........................121

Table 8. Portugal's Household Disposable Income - Net, \% of Annual growth rate (2007-2015)

Table 9. Portugal's Real GDP Forecast - Total, \% of Annual growth rate (20072015)

Table 10. Portugal's Short-Term Interest Rates (1997-2008) 125

Table 11. Portugal's Long-Term Interest Rates (1997-2008). 126

Table 12. Portugal's Government Deficit (2009-2015)..... 132

Table 13. Portugal's General Government Debt (2009-2015).

Table 14. Portugal Unemployment Rate (2009-2015).

Table 15. Portugal's Tax Revenue (2007-2015) .134

Table 16. Portugal Public Social Spending (2009-2015). .135

Table 17. Portugal's Public Pension Spending (2007-2013) ..................................136

Table 18. Portugal's Public Unemployment Spending (2007-2013).........................136

Table 19. Portugal's Public Spending on Family Benefits (2007-2013) ...................137

Table 20. Portugal's Public Spending on Incapacity (2007-2013) ...........................137

Table 21. Portugal's Public Spending on Labour Markets (2007-2015)..... 138 
Table 22. Portugal's General Government Spending (2009-2015)

Table 23. Stability Programme 2010-2013 (PEC I): Main Retrenchment Measures on Social Expenditure

Table 24. Portugal's Short-Term Interest Rates (2009-2015)

Table 25. Portugal's Long-Term Interest Rates (2009-2015)

Table 26. Main Austerity Measures on Public Expenditure with Social Citizenship Rights (MoU - May 2011).

Table 27. Main Austerity Measures for 2012 on Public Expenditure with Social Citizenship Rights (First Update - September 2011)

Table 28. Main Austerity Measures for 2012 on Public Expenditure with Social Citizenship Rights (Second Update - December 2011) ....

Table 29. Main Austerity Measures for 2012 on Public Expenditure with Social Citizenship Rights (Third Update - March 2012)

Table 30. Main Austerity Measures for 2013 on Public Expenditure with Social Citizenship Rights (Sixth Update - December 2012).

Table 31. Main Austerity Measures for 2013 on Public Expenditure with Social Citizenship Rights (Seventh Update - May 2013) .181

Table 32. Legislative Measures on Cash Benefits of Social Citizenship Rights (April 2011 - May 2014)

Table 33. Portugal's Income Inequality - Gini coefficient (2007-2015) .194

Table 34. Portugal's Poverty Rate - Total, Ratio (2007-2015) .195 


\section{List of illustrations}

Illustration 1. Portugal's Budgetary Consolidation Programming in \% of GDP (2006-2011)

Illustration 2. The Rise of Portugal's Short-Term Interest Rates in 2010 143

Illustration 3. The Rise of Portugal's Long-Term Interest Rates in 2010 ..............146

Illustration 4. MoU's Fiscal Adjustment Measures for 2011-2013 ........................156

Illustration 5. MoU's Fiscal Adjustment Measures per areas for 2012-2013 ..........166

Illustration 6. Austerity Measures per Area in the 2013 State Budget ...................176

Illustration 7. Budgetary Outturn on Cash Benefits of Social Security (JanuaryAugust 2013) 


\section{Introduction}

Since 2008, ordinary people in Europe have experienced the impact of austerity measures with severe consequences at both the economic and social levels. Following the 2008 financial crisis, the cumulative effect of multiple policy changes was devastating for the most vulnerable and very damaging to the entitlements to social protection across Western societies (International Federation of Social Workers [IFSW], 2016; O'Hara, 2013; United Nations [UN], 2009).

On May 4, 2011, ordinary Portuguese citizens woke up to an economic and social turmoil. The price to be paid for a $€ 78$ billion debt bailout from the European Union (EU) and the International Monetary Fund (IMF), signed the night before, was tremendous. Portugal's public deficit of $-11.17 \%$ of Gross Domestic Product (GDP), at the end of 2010, forced the acting government to slash public spending drastically in return for financial help. Under the terms of the deal, several structural reforms and deep fiscal measures (commonly known as austerity measures) on the welfare state were to be adopted. These announcements were shocking for the most vulnerable and for the working-class population. But why did the austerity plan include the welfare state? Was the public welfare state responsible for such $11.17 \%$ deficit of GDP at the end of 2010 ? The answers are complex.

The causes for the rise of the Portuguese debt began long before 2011. Its combination with the European sovereign debt crisis ended up creating a snowball effect of European regulations and austerity measures adopted to ease the financial crisis within the single-currency Eurozone area.

The rules in the EU, particularly within the Eurozone area (countries that share the Euro as a common currency), have forced Greece, Ireland, Portugal, Spain, and Cyprus to capitulate to EU 
and markets demands with the adoption of harsh austerity cuts through a combination of spending cuts and tax hikes. As a result, these countries have decreased public spending for social protection which in turn contributed to the significant erosion of their welfare systems (Blyth, 2013; Lapavitsas et al., 2012; Schafer \& Streeck, 2013)

In 2010, while a social worker in Portugal, I started to witness the beginning of the austerity debate, both at political and societal levels. Narratives such as "the poor and the middle class are being made to pay for this crisis" and "they are spending our money to give to the banks" were common. The pressure from the EU and the financial markets initiated a political battle - citizens versus markets. The political agenda in Portugal became tied to the demands of the EU headquarters and the international financial system (markets). Some relevant questions can be asked. Was the banking system responsible for the 2008 financial crisis and consequently the 2010 European debt crisis? How did the EU membership and single-currency contribute to this crisis? Was the public-spending on social welfare a "time bomb"? How did unemployment and family benefits, old-age pensions, social assistance (minimum income benefits), public health care services and education become the target of a financial and ideological battle within a globalized economy? What does or did public debt, interest rates, credit rating agencies and the rules of the Stability and Growth Pact (SGP) have to do with the austerity measures adopted or imposed on Portugal? The austerity saga in Portugal started in March 2010 with the discussion and approval of the Stability Programme (SP) (2010-2013), known in Portugal as "PEC I" (Programa de Estabilidade e Crescimento 2010-2013), which introduced the first package of austerity measures.

In May 2010, two months after the approval of PEC I (SP I) 2010-2013 approved in March 2010, the Portuguese government announced a new group of measures that revised and updated the initial PEC I. This revised version came to be known as PEC II (SP II 2010-2013). In September 
2010, one month before the submission and approval of the State Budget for 2011, the Portuguese government announced additional austerity measures to calm down the financial markets. This new package was known as PEC III (SP III 2010-2013). However, the austerity saga continued with the 2011 budget's approval at the end of November 2010. It again introduced harsh austerity measures. After the budget's approval, José Socrates, the Portuguese prime minister said "This budget contains difficult and demanding measures for all Portuguese, but there are no alternatives to get Portugal out of the centre of a large financial crisis" (Govan, 2010, para. 9). By the end of 2010, the costs of borrowing money from the markets reached unprecedented levels. In the 2011, interest rates continued to soar drastically, and, again, the financial problems worsened. In order to avoid a bailout, the government proposed, one more time, new austerity measures to be included in the new SP 2011-2013 (know as PEC IV). The lack of political consensus left the government isolated, and the new austerity plan was defeated in the parliament which led to the resignation of the government. The political turmoil and the speculation of the international markets pushed Portugal to the EU-IMF bailout, signed on the 3rd of May. Therefore, the social and economic impact of austerity measures in Portugal, between March 2010 and May 2011, was enormous. The unemployment rate rose quickly to 10 per cent. The poverty rate and income inequality also increased as a result of the cuts and taxes adopted. A further analysis of Portugal's austerity measures will be provided later in this Introduction.

This dissertation in social work adopts a structural analysis. It focuses on the financial, economic and social crisis that dramatically affected the very core of the welfare state in Portugal, following the 2008 financial crisis. It examines the austerity measures adopted between March 2010 and May 2014 under the SP (2010-2011) and the Memorandum of Understanding (MoU) (2011-2014) with the Troika (composed of the European Commission, the European Central Bank, 
and the International Monetary Fund) that have directly affected the allocation of funding towards the welfare state, and the restriction of access to social citizenship rights.

Thus, I argue that the analysis of the retrenchment of the welfare state under the paradigm of austerity is of significant importance. The impact of the austerity measures adopted in Portugal between 2010 and 2014 profoundly affected the rights of social citizenship and the well-being of citizens. Two questions are at the heart of this dissertation. First, How and to what extent did the 2008 financial crisis and the politics of austerity that followed (2010-2014) change the nature of the welfare state in Portugal? Second, Since the 2008 financial crisis, what was the impact of austerity on social citizenship rights caused by the measures adopted under the Stability Programmes (between 2010 and 2011) and the Memorandum of Understanding (between May 2011 and May 2014)? I will attempt to answer these questions through a case study on the impact of austerity measures on the rights of social citizenship in Portugal during the period from 2010 to 2014.

\section{The 2008 financial crisis}

The 2008 financial crisis started in the United States (US) as a result of the crash of its financial system. In mid 2007 a housing bubble in the US market called subprime mortgage crisis affected almost 6 million people. The foreclosures on housing hit white middle-class areas and African-American families in Florida, California, Arizona, Nevada and Ohio. Housing values

dropped substantially all across the country. What happened that caused the crisis? The answer lies in the deregulation of the US banking system that began with the deregulation of financial 
markets initiated in the 1980s and who later exacerbated under the presidencies of Bill Clinton and George W. Bush (Blyth, 2013; Harvey, 2010a; Piketty, 2014).

The financial deregulation that led to the transformation of the banking system has been characterized by disintermediation, securitization and by the rise of "repo markets" (Blyth, 2013, p. 49). Large corporations started lending money to one another without an adequate supervision from the authorities, what became to be known as "shadow banking" - a system that provides financial services to regulated banks and to the economy (Blyth, 2013; Harvey, 2010a). Blyth (2013) explains that under that new model of banking system, while traditional banks lost market share, they obtained cheaper money to lend from private investors (financial markets). Thus, the "repo market" can be defined as the system that invests assets and money on behalf of investors. Under this new system, banks started buying cheaper money which in turn facilitated cheaper lending and an expansion of the mortgage credit to high-risk borrowers (Blyth, 2013, p. 23). But how did banks start lending money to "high-risk" families? Basically, they began to do this through new financial products and instruments that masked the risk of funding high-risk mortgages. It was the invention of a new unregulated financial instrument called "derivatives" that amplified the crisis. According to Blyth (2013, p. 25), derivatives are contracts that represent assets, either a property, a claim on property or income. These contracts are a bet that pays out based on how a particular asset performs over a particular time period. Thus, the derivatives combine a package of high-risk mortgages that are sold in the bond market. Their value can go up or down based on a correlation of factors, such as market confidence and the value and performance of the assets (Blyth, 2013; Duca, 2013; Harvey, 2010a).

This sheds light on how high-risk mortgages were funded by repackaging them into packages that were sold to investors. The prices of the houses and the high risk of those mortgages 
contributed decisively to the spiral of events. From the point of view of the mortgagees, their mortgages were mostly fraudulent, improperly written, often with conditions that the mortgagees did not understand. When those high-risk families were unable to afford to pay their mortgages as a result of the rise of interest rates, the housing bubble burst. Therefore, the lack of an adequate regulatory agency was at the centre of the problem (Blyth, 2013; Harvey, 2010a; Piketty, 2014; Stiglitz, 2010).

Mortgages were worth more than the value of the houses, which led to a spiral of foreclosures in the housing market. By the fall of 2008, the housing bubble hit Wall Street and forced the crash of the entire financial system in what came to be known as the "subprime mortgage crisis" (Blyth, 2013; Harvey, 2010a; Piketty, 2014). On September 15 2008, the investment bank Lehman Brothers collapsed. Its bankruptcy froze the entire global financial system and created a crisis of confidence and liquidity among national banks and international and private investors such as pension funds, European banks and governments (Blyth, 2013; Piketty, 2014). The amount of "toxic" mortgage debt held by these institutions and investors pushed stock markets into panic. The crisis rapidly spread out through the EU affecting the economies of the United Kingdom (UK), Ireland, Spain, Portugal, Greece and even Iceland which was not an EU member-state (Blyth, 2013; Clarke \& Newman, 2012; Harvey, 2010a; Lapavitsas et al., 2012; Schafer \& Streeck, 2013; Streeck, 2014).

What initially started as a liquidity crisis following the 2008 financial crisis generated a recession in many European countries, with implications not only for the banking system, but also for the economy and the public finances of several of EU member states. By 2010, a sovereign debt crisis unfolded in Europe which was threefold: a bank crisis, a crisis of public finances and a crisis of the real economy (Blyth, 2013; Streeck, 2014). So, what did the European sovereign debt 
crisis look like? Blyth (2013) explains that, with the exception of Greece, the sovereign debt crisis was not generated by excessive government spending, but by bailing out and recapitalizing the European banks. Thus, the European debt crisis was a consequence of the rupture of national banking systems across several European countries (Blyth, 2013). For example, in November 2008, Portugal had to nationalize the BPN bank (Banco Português de Negócios), which, at the time, had $€ 700$ million in accumulated losses most of it prior to the 2008 financial crisis. The government nationalized the BPN to protect depositors and strength the capital ratios of the bank. As a result of BPN's nationalization, the government created a grant program with $€ 4$ billion Euros to recapitalize Portuguese banks, if necessary.

As Lane (2012) explains, the boom in the financial markets and credit growth occurred between 2003-2007, as a result of stable, low interest rates over this period that led to a spike in investment in public and private debt. Then, the increase in both public and private debt fueled the accumulation of bank debt across Europe (Blyth, 2013; Schafer \& Streeck, 2013; Streeck, 2014). But how did the private debt of European financial institutions become public debt? To maintain financial and economic stability, the European governments decided to bail out and recapitalize their banks, turning private debt into public debt. As Blyth (2013) explains, the European banks generated the sovereign debt crisis. It was a crisis of the markets that became a state responsibility. For that reason, the pressure on European banks increased as a result of the 2008 financial crisis which in turn forced the European Central Bank (ECB) to announce a two-year €200bn euros stimulus package to help the European economy and its bank sector. Initially, only Greece faced problems with government public spending. As a result, the deficit of $12.5 \%$ of GDP announced in October 2009 by the new Greek government pushed the European financial system into a deeper crisis. Some of the reasons for it were the expansionary public policies undertaken by several 
Greek governments between the 1980s and 1990s, the increase in income and public consumption, and the lower productivity growth and tax revenues that led to higher public deficits over several years. In order to adopt the Euro as a common currency, Greece has hidden its debt, reaching $165 \%$ of GDP in 2011 (Blyth, 2013). Under the rules of the Stability and Growth Pact (SGP) governments are committed to a deficit of no more than $3 \%$ of GDP and to a public debt level of no more than $60 \%$ of GDP. By May 2010, Greece signed a three-year financial rescue package of $€ 110 \mathrm{bn}$ euros with the IMF and the EU to reduce the public deficit from -13.5\% to -3\% of GDP by 2014 .

In September 2010, the Irish government announced the bailing-out of the Anglo-Irish Bank with $€ 32$ bn euros pushing the public deficit to 32\% of GDP. As a result, in November 2010 the Irish government requested $€ 85 \mathrm{bn}$ euros in financial assistance from the IMF and the EU. In May 2011, Portugal also requested financial assistance from the EU and the IMF in the total amount of $€ 78 \mathrm{bn}$ euros over a three-year period. Then, in July of that same year the Troika composed of the European Commission, the ECB and the IMF approved a second bailout package to Greece in the total amount of $€ 109$ bn euros (Amini, 2015; Blyth, 2013; European Commission, 2017a; Schafer \& Streeck, 2013).

These actions show the extensive support needed to deal with the damage caused by the 2008 crisis in financial markets. In fact, the European debt crisis was a symptom and cause of a heavy dependence of the economy and the public finances from the speculation of the financial markets (Blyth, 2013; Harvey, 2010a; Piketty, 2014; Streeck, 2014). The problem also lay in the fiscal and monetary risks brought on by the EMU and its common currency Euro (see Chapter IV), which amplified the fiscal impact of the 2008 financial crisis. According to $\operatorname{Scharpf}(2013$, p. 114), the EMU cannot be considered an "optimal currency area" since the economies of the different EU member states are not homogeneous on inflation rates, wages, price stability, etc. At the same 
time, the restrictions imposed on the monetary union by the EU and by its ECB shaped the type of country responses and recovery to the crisis (Blyth, 2013; Lane, 2012; Piketty, 2014). What initially started as a crisis of the financial system and its banking sector became a crisis of public finances and public debt (Blyth, 2013).

Financial crises are common throughout the history of capitalism. From war, oil or property and urban development, there have been several financial crises around the world. Since the Second World War, the biggest global crisis of capitalism occurred in 1973 with the international oil crisis that led to the crash of stock markets and to the increase of land prices (Harvey, 2010a). The crisis in the 1970 s was a turning point which marked the end of the period of postwar reconstruction dominated by a fifty-year period of "Keynesianism", an economic theory and policy approach that argues for a key role for the state in regulating the economy to generate full employment and economic growth (Piketty, 2014; Streeck, 2013, 2014; Wolff \& Resnick, 2012). As Blyth (2013, p. 39) also explains, Keynesianism "argues that consumption drives investment, not saving." It was during that period that Keynesianism was replaced by a new global socioeconomic order which has since come to be known as neoliberalism. According to Harvey (2005, p. 64), in theory, "the neoliberal state should favour strong individual private property rights, the rule of law, and the institutions of freely functioning markets and free trade." The dominant theme of neoliberalism has been free markets in which individuals maximize their material interests (Crouch, 2011; Harvey, 2005, 2010a, 2014). According to the tenets of neoliberalism, the supply and demand for goods and services will adjust to each other through the pricing mechanism without state interference. No regulation of markets is necessary, no cash assistance to increase demand, no supply management, no intervention to protect employment or the price of labour (Crouch, 2011; Harvey, 2005, 2010a, 2014). Thus, the neoliberal counter-revolution of the 1970s 
was nothing less than an attempt to impose on the rest of the world an Anglo-American vision of free market forces (Blyth, 2013). In fact, the politics of monetary stabilization undertaken in the early 1980s by the Reagan administration in the US and by the Thatcher government in the UK represented the beginning of the era of austerity which culminated in the assumption that public debt must be solved by deep spending cuts to the social safety net (Blyth, 2013; Streeck, 2013, 2014). However, it was precisely this form of capitalism characterized by lowered levels of market regulation and increased levels of financialization through private debt that fueled the 2008 financial crisis and the 2010 European sovereign debt crisis that followed (Blyth, 2013).

To more fully understand the transformation that led to the 2008 financial crisis I sought guidance from Streeck's (2014) interpretation of the way Western capitalist economies adopt monetarist policies and increase their public debt. According to Streeck (2014, p. 63), "the crisis of public finances is the contemporary form of a functional problem of the modern state." In Streeck's interpretation there has been a transformation of the tax state into a debt state. But what does that mean? Since the advent of neoliberalism in the 1970s, Western governments started borrowing money in the market to cover the gap between public expenditure and public revenue leading to a substantial increase of public debt as a result of citizens' pressure on political parties and governments (Streeck, 2014). The liberalization of the markets and the development of the debt state through the 1980s and 1990s has increased the dependence of the state on financial markets which forced governments to serve the interests of their creditors (Piketty, 2014; Schafer \& Streeck, 2013; Streeck, 2014).

As a result, the doors were open for the second "Great Transformation" - the 2008 financial crisis and the politics of austerity - that initiated a controversial confrontation between citizens, state and markets. As Harvey (2005, p. 70) explains, "in the event of a conflict, the typical 
neoliberal state will tend to side with a good business climate as opposed to either the collective rights (and quality of life) of labour or the capacity of the environment to regenerate itself." Neoliberal states typically favour the integrity of the financial system and the solvency of financial institutions over the well-being of the citizens (Harvey, 2005, 2010a, 2014).

Thus, following the 2008 financial crisis and the 2010 European debt crisis, the EU and its Eurozone members decided to shore up the banks and the credit system with taxpayers' money. Meanwhile citizens' social protection and security were abandoned and replaced by severe austerity measures (Blyth, 2013; Clarke \& Newman, 2012; Gray \& Webb, 2013; Lapavitsas et al., 2012; Piketty, 2014; Schafer \& Streeck, 2013; Streeck, 2014).

\section{The politics of austerity}

The most recent wave of European austerity began in 2010, as a consequence of the 2008 financial crisis and the 2010 European debt crisis, after the G20 began to focus on austerity policies during the "2010 Toronto Summit" (Group of Twenty [G20], 2010). In the EU, particularly in the Economic and Monetary Union (EMU), commonly known as the "Eurozone" or "Euro area", the emergency responses to the 2008 global financial crisis and the 2010 European debt crisis included bailouts, the de facto nationalization of banks and financial institutions as well as Keynesian stimulus spending to sustain consumption and stabilize the Eurozone banking system (Blyth, 2013; McBride, 2014; O’Brien \& Zhang, 2014; Schafer \& Streeck, 2013; Streeck, 2014).

According to Blyth (2013, p. 2), austerity can be defined as "the policy to cut state's budgets to promote growth." It has been the preferred policy in all OECD (Organization for Economic Co-operation and Development) countries since the 2008 financial crisis. Austerity has 
also been used as "a form of voluntary deflation in which the economy adjusts through the reduction of wages, prices and public spending to restore competitiveness, which is (supposedly) best achieved by cutting the state's budget, debts and deficits" (p. 2). Austerity was formally introduced by the European Commission and the ECB through the SP, which was enacted in 2007 to enforce fiscal responsibility and an annual budget deficit no greater than $-3 \%$ of GDP, and a national debt that is lower than $60 \%$ of GDP, to all EU member-states within Eurozone. Austerity was further strengthened by the "Six-Pack" (2011), the "European Stability Mechanism" (2012), the "Two-Pack" (2013), and the "Treaty on Stability, Coordination and Governance" (2013). In some EU member-states like Portugal, Ireland, Greece and Cyprus, austerity was also imposed by the IMF, as a condition for financial assistance to avert default and national insolvency. This occurred in Portugal between 2011 and 2014. Among the austerity measures adopted were cutting of wages in the public sector, the reduction of public spending and the raising of taxes. Other structural reforms adopted through the crisis included labour market flexibility, the introduction of pension conditions, the privatization of public services and state-owned companies and so on (Ferguson, Ioakimidis, \& Lavalette, 2018; Gilbert, 2013; Harris, 2014; Lapavitsas et al., 2012). These measures changed the relationship between the economy and the state, capitalism and democracy.

Schafer and Streeck (2013) explain that, "austerity results when the ability to generate revenues is limited while at the same time spending needs to increase" (p. 2). This decline of state capacity was due to the gap between public revenues (taxes) and public expenditure that "forced governments to set aside a growing share of their budgets to pay interest(s) to their creditors (Streeck \& Mertens, 2013). This represented a second wave of capital market liberalization, and the consequent increase of private debt. Crouch (2011) calls this new phase of capital development, 
“privatized Keynesianism" as a way to replace government debt with private debt (Piketty, 2014; Streeck, 2014).

\section{Austerity in Portugal (2010-2014)}

I have mentioned above that the contemporary wave of austerity in Portugal started in 2010 with the approval of the SP 2010-2013, known in Portugal as PEC I. Between March 2010 and May 2011, the Portuguese government adopted several austerity measures to meet the deficitreduction targets imposed by the EU regulations and by the financial markets. While the main goal was seeking the reduction of the public deficit, the government was also trying to avoid the need for an emergency bailout from the EU and the IMF. In March 2010, the Portuguese government outlined its first package of austerity measures that included tax hikes and pay cuts in order to reduce its 2009 budget deficit of $-9.8 \%$ of GDP (Organisation for Economic Co-operation and Development [OECD], 2018a). The fact that the Eurozone debt crisis exacerbated over the summer of 2010 created even more problems for Portugal's financial system. The cost of borrowing money on financial markets increased prohibitively due to the high interest rates that Portugal had to pay to investors (Blyth, 2013; Lapavitsas et al., 2012). By the end of 2009, the government debt was 96.2\% of GDP (OECD, 2018b). The austerity measures announced in March (PEC I), May (PEC II) and September (PEC III) of 2010 had a severe cumulative impact and effect on the lives of the most vulnerable and working-class citizens. Among those measures were: cuts to public pensions; a $25 \%$ cut on cash welfare benefits, including unemployment insurance; cuts between $3.5 \%$ and $10 \%$ on the salaries of public employees earning more than $€ 1,500$ a month; an increase in the value added-tax to $23 \%$, etc. Clearly, these measures deepened even further the recession of the 
economy throughout the year and lead to an unemployment rate of $10.77 \%$ in 2010 (OECD, 2018c).

In the beginning of 2011, the borrowing costs for Portugal became unsustainable. The interest rates on 10-year bonds rose to $7.1 \%$ (in January 2011) which forced the Portuguese socialist government to propose another package of austerity measures - the revision and update of the SP (known in Portugal as PEC IV) in March 2011. Basically, the investors were "demanding" more measures in order to buy Portuguese public bonds at lower interest rates (OECD, 2018d). Those measures were also a response to the rating agencies that were responsible for assessing and rating the quality and credibility of Portugal's public debt and its banking system. Thus, the austerity measures proposed in the PEC IV (SP IV) included further tax hikes, cuts to social spending (social assistance, unemployment insurance, pensions, family benefits, public health care services, etc.) and further cuts in the salaries of public servants by $5 \%$ on average, etc. However, the Portuguese lawmakers rejected such an austerity package, and the government resigned.

In May 2011, Portugal reached a deal for a three-year bailout program with the so-called Troika, composed of the European Commission, the ECB and IMF. Under the MoU with the Troika, in order to receive the $€ 78$ billion loan, the Portuguese government agreed to implement several "reforms" (known as austerity measures) to promote fiscal consolidation, stability in the financial market and boost the growth of the economy (Bruneau, Jalali, \& Colino, 2015; European Commission, 2011a; Government of Portugal [GovPT], 2011a; International Monetary Fund [IMF], 2011a, 2011b). Among the austerity measures proposed by the European Commission, the ECB and IMF or voluntarily proposed and adopted by the Portuguese government were the cuts to wages in the public sector, a further reduction of public spending and the raising of taxes. Other 
structural reforms adopted through the crisis included greater labour market flexibility, the introduction of changes to pension conditions, and the privatization of public enterprises and services (Blyth, 2013; Lapavitsas et al., 2012).

All the austerity measures proposed and adopted in Portugal under the SP and the MoU signed with the Troika, between 2010 and 2014, will be carefully explored in Chapters V and VI.

\section{Social work responds to the financial crisis}

This dissertation is intended to make a contribution to social work and political economy. The structural approach in social work provides an insightful frame to analyze the process of retrenchment of the welfare state in Portugal under the paradigm of austerity. The significance and implications of this dissertation lie in its potential to contribute to the body of research on political economy, and on public welfare state provision and redistribution as part of the rights of citizenship proposed by T.H. Marshall (1950) and Esping-Andersen (1990). In addition, this research will add an important contribution to structural and radical social work in scholarly literature, as it offers a detailed account of the process and degree of welfare retrenchment under the paradigm of austerity following the 2008 financial crisis. Structural and radical social work approaches place an emphasis on historical, economic, social, political and legislative contexts that influence social and material conditions, the formulation of laws, the allocation of funding towards the welfare state, and the restriction of access to social citizenships rights (Duarte, 2017). Since the 2008 financial crisis, I argue that ordinary citizens in modern capitalist economies have been living in a highly unequal world, meaning that there are many more people finding themselves in lower income brackets or living in far poorer conditions as a result of the politics of austerity that unfolded since 
the 2008 financial crisis. Therefore, structural social work offers the lens and tools to examine closely the inequalities and the retrenchment of the welfare state that emerged under the paradigm of austerity (Duarte, 2017).

In 2014, the International Labour Organization (ILO) published the World Social Protection Report 2014-15: Building Economic Recovery, Inclusive Development and Social Justice with recommendations to realize social protection coverage and benefits (International Labour Organization [ILO], 2014). In 2016, the IFSW endorsed the policy position paper The Role of Social Work in Social Protection Systems: The Universal Right to Social Protection which "addresses the need for all people to have access to competent social protection systems" (IFSW, 2016, para. 2). Its recommendations provide a useful blueprint for a call for the promotion of social justice and for the effective exercise of civil, political and social rights by those who are disadvantaged in terms of power and resources. Social workers internationally agree that, by adopting austerity measures, the EU and its member states have violated its fundamental obligations of maximizing the principles of social equality, fairness and social justice of those who need and seek support from welfare state programs and services.

Ferguson (2009) asked, "Where's the beef?" He suggested that, to assume a political stance, social workers' commitments need content, i.e., theory and research production. Yet, the understanding and analysis of the process of retrenchment of the welfare state under the paradigm of austerity remains relatively unexplored by mainstream social work scholars and practitioners who have generally overlooked the political economy of the welfare state. Thus, this dissertation analyzes the impacts of the politics of austerity adopted on cash benefits of social citizenship rights in Portugal since the 2008 financial crisis. 


\section{How to understand what happened}

This dissertation advances the thesis that the austerity measures adopted in Portugal between 2010 and 2014 under the SP (between 2010 and 2011) and the MoU (between 2011 and 2014) have considerably eroded public welfare provision in Portugal by decreasing the degree of decommodification of social citizenship rights and thereby increasing the conditionality of public welfare programs and services. A rosy account of the mainstream narrative of social citizenship rights under the new "mantra" of austerity - the so-called "market justice" - argues that social citizenship rights are tied to the objective facts of the market economy and to the hegemonic ideologies of the capitalist class; that is, to pursue and protect the current neoliberal economic order (Blyth, 2013; Schafer \& Streeck, 2013; Streeck, 2014). Therefore, the need for austerity was used as a "common sense" justification to deplete even more the public welfare state (Blyth, 2013; Piketty, 2014; Streeck, 2014).

This dissertation begins with an affirmation that commonly held rights represent the essence of citizenship. It claims that social citizenship rights are key to the redistribution of resources for meeting economic and material needs. It uses the Marshallian framework of social citizenship rights to define and discuss the public welfare provision under the paradigm of austerity following the 2008 financial crisis.

Beyond proposing a framework that informs and guides the definition and protection of rights and entitlements of social citizenship in the 21 st century, this dissertation provides a blueprint and analysis of the impacts and outcomes of austerity measures in the Portuguese welfare state between 2010 and 2014. Through legislation, policy documents and secondary data from OECD, this dissertation provides a consistent and detailed account of the austerity measures 
adopted in Portugal between 2010 and 2014 to the cash benefits of social citizenship rights minimum income (social assistance), unemployment insurance and old-age pensions. But why analyze only the austerity cuts and changes to cash benefits of social citizenship rights? Because cash benefits enact two of the most distinctive forms of equality, that is, the economic and social type (see Chapter II) (Cohen, 1997, 2011; Marshall, 1950, 1981; Miller, 1995; Moscovitch, 1981).

\section{Organization and layout}

Chapter I explores the theoretical framework of this research through two interconnected complementary theoretical approaches: 1) the conceptual framework of citizenship in the work of T.H. Marshall (1950); and 2) Esping-Andersen's (1990) approach to welfare provision and redistribution. These theoretical approaches provide the lens and tools that employ a set of perspective attributes that speak to the thesis of this dissertation - the impact of austerity on public welfare provision and redistribution as part of citizenship rights proposed by T.H. Marshall (1950).

Chapter II offers an explanation about the nature of social citizenship, its essential qualities and its characteristics. It discusses the central organizing principles of a public welfare state and its role in welfare provision and redistribution as part of those citizenship rights proposed by T.H. Marshall. It determines the components and dimensions of the process of retrenchment of the welfare state and proposes variables to analyze the different types and degrees of retrenchment that occurred under the paradigm of austerity.

Chapter III explores the key and most significant events in Portugal from the creation of the universal and democratic public welfare state in 1976 to the reform of the Social Security System in 1996 that created the Guaranteed Minimum Income (Rendimento Mínimo Garantido). 
It contextualizes and details the 1974 Carnation Revolution and analyzes the economic and political factors prior to and after Portugal joining the EU (former EEC) in 1986.

Chapter IV introduces the European budgetary rules enacted by the Treaty of Maastricht and by the Stability and Growth Pact (SGP) in order to understand the process of budgetary consolidation initiated by Portugal in 2005-2007 that culminated in the imposition of deep austerity measures in Portugal between 2010-2014.

Chapter $V$ details the different types of austerity measures on cash benefits of social citizenship rights adopted by the Portuguese government or imposed by the Troika under the Stability Programmes (2010-2011) and the Memorandum of Understanding (2011-2014) signed with the Troika.

Chapter VI summarizes and discusses the austerity measures adopted on cash benefits of social citizenship rights - minimum income (social assistance), unemployment insurance and oldage pensions, adopted in Portugal between 2010 and 2014. It further interprets the findings by revisiting the research questions, examines the key findings with reference to the literature, and offers contributions to the current knowledge base. It concludes by evaluating the study and offering recommendations for policy directions and future research. 


\section{Chapter I: Theoretical framework}

\section{Introduction}

The social and political theories underlying the research presented in this dissertation are Marshall's framework on citizenship rights and Esping-Andersen's theory and methodology for defining and comparing welfare provision. The first theory, Marshall's (1950) framework on citizenship rights, is an approach that models the definition of the welfare state as part of the gradual development of citizenship rights. The second theoretical framework, put forward by Esping-Andersen, shows how contemporary welfare states can be organized. Esping-Andersen's (1990) approach and methodology contribute to the definition and classification of the different welfare systems and their most significant characteristics.

The intersection of these theories and approaches allows for the establishment of a framework to analyze the public provision and redistribution of resources to meet economic and material needs through the agency of the state. This is done to critique the dynamics and to bring to light the contradictions that underpin what I call a new phase in the retrenchment of welfare capitalism in modern market societies, as a result of the new paradigm of austerity following the 2008 financial crisis.

But how do these three theories fit together? Are they complementary? To what extent do they contribute to understanding the retrenchment of the welfare state under the impact of the politics of austerity? Marshall's (1950) framework of social citizenship establishes the central organizing principles in the development of the welfare state. It offers key questions about the role of the state in welfare provision and redistribution as part of citizenship rights. Esping-Andersen's 
$(1990,1999)$ theory and methodology offer important dimensions to classify, measure and compare the nature of public welfare provision and redistribution in the different welfare systems.

A myriad of questions guide and explain the importance of proposing a link between these two approaches. Thus, what does Marshall's social citizenship mean? What entitlements does social citizenship imply? Can Marshall's definition of social citizenship be reinterpreted? Is Marshall's framework of social citizenship intemporal? Can it be applied to different societies and types of welfare states? Are citizenship rights in the Marshallian tradition embedded in the notion of liberal democracy? Is Marshall's social citizenship built on Fabian socialist ideals? Are social citizenship rights conditional to membership, status, duties, obligations and moral or ideological values? Are class, gender, and legal status taken into account in Marshall's social citizenship ideas? How and to what extent do social citizenship rights mitigate and decommodify wage labour and the risks of the market? Do social citizenship rights differ in each welfare regime? How do countries either adhere to the market or diverge from it regarding social citizenship rights? Why is it important to have an adequate understanding of state functions and their relation with the process of capitalist accumulation and crisis? How does the analysis of state activities explain the interests of the ruling class? How do the different ideological perspectives view social citizenship rights and the welfare state? Why have social citizenship rights and the welfare state been at the centre of a political discussion and social conflict? To what extent does Marshall's citizenship framework speak to the analysis of the retrenchment of the welfare state under the paradigm of austerity? How do market-oriented approaches affect social citizenship rights? What are the contemporary dynamics behind the structural foundations of social and economic inequalities? These are the questions that inform the framework that guides this study. 
These two approaches provide analytical, normative and methodological insights, embedded in Fabian socialist and structural social work perspectives, to provide an adequate understanding of the 2008 financial crisis and its relation to the processes, impacts and outcomes of the politics of austerity carried out in the Portuguese welfare state.

\section{Marshall's account of citizenship}

The Marshallian framework of citizenship rights is the foundation for defining and discussing the nature of public welfare provision of welfare capitalism in the 21 st century. It offers a part of the framework that speaks to the thesis of this dissertation and to the epistemological perspective at hand - the public provision of material basic needs, programs and services to enable everyone to be a citizen and fully participate in society.

Lister writes that citizenship thought dominates, both historically and today, the terrain of Western political thought (Lister, 2003). The understanding of citizenship can be appreciated through the practical and policy implications of its rights, discourse and performance. The notion of citizenship provides an organizing feature that reconciles collective rights and ideals with individual rights and responsibilities (Lister, 2003; Turner, 2001).

Marshall's (1950) citizenship framework incorporates Fabian socialist notions of equality, freedom and fellowship in what became the principal paradigm of the post-Second World War period (George \& Wilding, 1985; Lister, 2003, 2010; Williams, 1989). Marshall's ideas were presented in 1949 during a series of lectures at Cambridge University and then published in 1950 as an extended essay called Citizenship and Social Class (Marshall, 1950). The context of his work is the post-Second World War period and, in particular, the period of the creation of the British 
welfare state. Thus, the citizenship framework employed in this study represents a modern account of citizenship rights offered by T. H. Marshall (1950). The definition of citizenship takes into account the kind of ideal society and political system that establishes the practice of state intervention to deal with social problems (George \& Wilding, 1985; Lister, 2003). The Fabian socialist tradition, which flourished from the early 1900s was central to building the modern welfare state after 1945 (George \& Wilding, 1985; Williams, 1989).

Marshall defines citizenship as "a status bestowed on those who are full members of a community. All who possess the status are equal with respect to the rights and duties with which the status is endowed. There is no universal principle that determines what those rights and duties shall be, but societies in which citizenship is a developing institution create an image of an ideal citizenship against which achievement can be measured and towards which aspiration can be directed" (Marshall, 1950, p. 28-29). Marshall's arguments derive from a perspective in which citizenship is seen as a set of processes involving the gradual development of citizenship rights, the public provision of welfare resources and an exclusionary process of building identities on the basis of a common or imagined solidarity within society (Turner, 1990, 2001). Marshall's interpretation of membership in a community refers to the national community, created and defined by a nation state. Nowadays, globalization and international political and legal entities, such as the EU, have redefined the borders and identities of the nation states. Being a member of a nation state also means being a member of an international organization that may define and redefine the rights and duties in a given nation state. Nonetheless, Lister (2010) states that membership in a community means, on the one hand, a universal status, a respectable economic independence and a constructive social participation and, on the other hand, a set of social and political relations, practices and identities that can be viewed as a sense of belonging. The problem 
with membership is in the struggle between the equality of citizenship and the inequalities of social class. Marshall's argument is that the rights of citizenship legitimate the inequality of social class. This relates to Marshall's concerns with the equality of status that provides the basis for social solidarity within the state and the broad civil society. A strong citizenship status depends on the existence of democratic governments that guarantee and promote citizenship rights to all members, regardless of their origin, ethnicity, gender, faith, education, income, or class. Marshall emphasized that the status of citizenship is essential to enhance equality, inclusion, and a degree of security and protection for all.

For Marshall, citizenship expands and enriches the dimensions of equality by extending its scope to the rights of citizenship. However, as Turner (1990) reports, the development of individual freedoms and political equality conflicts with the persistence of extensive social and economic inequalities. So, how did or does Marshall's citizenship framework become the means for mitigating those inequalities? He accomplished it through the extension of the duties and commitments of the state towards its citizens with an extensive set of publicly funded social programs and services. Turner (2001) argues that Marshall's citizenship framework is essentially a theory of entitlements where the state protects the people from the social contingencies caused by market forces with universal social citizenship rights. In this sense, Turner (2001) writes that Marshall's contribution aims to modify the negative impact of capitalist market forces through the enactment and redistribution of a set of rights and resources to all citizens, regardless of their economic and social class. Turner also observes that in Marshall's account "citizenship is a status position that mitigates the negative effects of economic class within capitalist society" (2001, p. 190). Therefore, this sheds light on how Marshall believed the status of the citizen could be reconciled with the inequalities created by capitalism. 
Marshall's (1950) citizenship framework employed in this study is tied to the development of modern democracy and capitalism. Thus, citizenship rights define the necessary elements and conditions for the full and democratic participation of people in society. The result is the framework proposed by Marshall where he identified the three types of elements or sets of rights of citizenship in a democracy: civil, political and social. Civil rights he writes, were developed in the 18th century, political rights in the 19th century while social rights were coming to the 20th century. In Marshall's view, civil citizenship rights represent the rights to individual freedom liberty and equality of the person, freedom of speech, thought and religion, the right to own property and the right to justice. Political citizenship rights include the right to vote and the right to participate in the exercise of political power (Marshall, 1950). For Marshall, the first two sets or elements (civic and political) were largely realized in the post-Second World War period, but the social element was not. For him, the social element of citizenship marks the final stage of development and the ultimate ideal of citizenship for the full participation of the individual in society (Marshall, 1950).

The growth of citizenship coincides with the rise of capitalism in the 18th and 19th centuries. The gradual development of citizenship rights was a stepping stone for the development of the modern welfare state in the twentieth century. Consequently, Lister points out, these sets of rights are "encapsulated in the increasingly influential notion of the 'indivisibility' of civil, political and social rights" (2003, p. 17). It is important to understand that, the extension and protection of civil, political and social citizenship rights to the most vulnerable and the working classes lies at the core of modern democracy (Giddens, 1996).

Despite the fact that Marshall's theory of citizenship was focussed on Britain, I believe that it can be applied to different Western societies in terms of its nature and philosophical ideals. In 
this regard, Turner (1990, p. 196) states that "Britain provides the principal example of a liberal strategy." It was a liberal state that incorporated the working-class through the welfare state without affecting the rights of the ruling classes (Mann, 1987). Therefore, Marshall's framework represents the application and operationalization of Fabian values and ideals (George \& Wilding, 1985; Williams, 1989). Fabianism believes in state intervention to correct, supplement and supplant the market system and the inequalities of class caused by capitalism through a gradual evolution. The role of the government is then essential to ensure that values of equality, freedom, fellowship, democracy and welfare are accomplished (George \& Wilding, 1985). It can be said that such values and ideals are the basis for a vision of society built on mitigating the class conflict caused by capitalism. Marshall's concern with the inequalities of capitalism led him to propose a mechanism of welfare provision to mitigate and stabilize the class struggle in the democratic capitalist society (George \& Wilding, 1985).

In this sense, the conceptual framework of citizenship in the work of T. H. Marshall (1950) can be defined as a rights-based approach that informs and guides the definition and protection of rights and entitlements to which citizens as right-holders are entitled to. A citizenship rights-based approach aims to assess the ability and commitment of states to fulfill their obligations towards citizens.

\section{The ideal of social citizenship}

In Marshall's account, the advent of social citizenship is concomitant with the rise of the modern welfare state. Marshall (1950, p. 11) defines social citizenship as "the whole range from the right to a modicum of economic welfare and security, to the right to share to the full in the 
social heritage and to live the life of a civilized being, according to the standards prevailing in the society." In other words, Marshall (1950) talks about welfare in its broadest sense as the right to health, education, economic and social welfare. Therefore, Marshall was proposing that full social citizenship would require the extension of welfare provision through the agency of the state.

In this regard, George and Wilding (1985, p. 78) observe that, in Marshall's view, the ideal of social citizenship through its programs and services "expresses the philosophy of the welfare state.” For Marshall, social citizenship rights aim to minimize the inequalities caused by capitalism and to stabilize the democratic capitalist society. Therefore, the establishment of Marshall's social citizenship is centred on the fulfillment of a set of state-guaranteed social and economic provisions as Briggs (1961) proposes, through the enrichment of the status of citizenship (Evers \& Guillemard, 2013; George \& Wilding, 1985; Kivisto \& Faist, 2007; Lister, 2003; Williams, 1989).

For example, Brodie (2008) points out that social citizenship rights reinforce the legitimacy and stability of liberal democracies as they represent a certain manifestation of social governance. Lister (2003, p. 17) makes a similar point when arguing that social rights are a legitimate expression of citizenship as "they help to promote the effective exercise of civil and political rights by groups who are disadvantaged in terms of power and resources." This analysis is made from the perspective that without social citizenship rights, gross inequalities may undermine civil and political rights, both of which are inherent in the ideal of social citizenship rights. In Marshall's account, the enrichment of the universal status of citizenship made through income distribution provided by welfare programs and the public provision of welfare services contributes to stabilize the status differences and to overturn or minimize economic and social inequalities (Marshall, 1950). 
Although Marshall's vision of social citizenship is universal and unconditional in the fields of public health and education services, other social citizenship rights such as programs of minimum income (social assistance) and public insurance (pensions, unemployment and sickness) may be provided or extended conditionally based on entitlement criteria such as prior contributions, age, or means-testing (Evers \& Guillemard, 2013). In this regard, Marshall proposes three criteria to assess the "degree of equalization" achieved through the rights of social citizenship: (1) whether the benefit is offered to all or to a limited class; (2) whether it takes the form of money payment or service rendered; (3) whether the minimum is high or low (Marshall, 1950, p. 54). His argument is that the state should provide a guaranteed minimum of certain essential goods and services, either universal or conditional on status and eligibility criteria. However, Esping-Andersen is critical of this view by arguing that the universal right to entitlements in cash or in kind (as services) is fulfilled only once access to these entitlements is linked with no or only minimal conditions (Esping-Andersen, 1990). Therefore, for Marshall, the strengthening of social citizenship does not simply consist in unconditional rights to make all members of society equal or to bring about a strong degree of decommodification, by offering a continuum from pure-market logic to publicly funded welfare programs and services. In turn, the achievement of social citizenship in Marshall's ideal requires establishing and strengthening citizenship status through social rights to protect citizens from the inequalities of social class caused by capitalism.

It is also important to understand that the notion of social citizenship understood here is also embedded in the second generation of human rights, recognized as "economic, social and cultural rights" and outlined in the United Nations (UN) Universal Declaration of Human Rights (UDHR) and in the UN International Covenant of Economic, Social and Cultural Rights 
(ICESCR). Thus, social rights are the rights of individuals or groups to receive different forms of social protection in order to realize their full potential as human beings. Articles 22, 23, 24, 25 and 26 of the UDHR affirm the right to employment, an adequate wage, housing, adequate food and clothing, education, adequate health care, social security and the right to be treated with dignity in old age (UN, 1948; UN Office of the High Commissioner for Human Rights [OHCHR], 1966). These rights are referred to as positive rights. They are only guaranteed by legal and constitutional mechanisms to meet "legal state obligations" in order to promote and preserve the wellbeing of the citizens. These rights only exist to the extent that they are protected, guaranteed and realized as a result of state action (Androff, 2016; Ife, 2012). This is why the rights of social citizenship proposed by Marshall (1950) and later extended and operationalized by Briggs (1961) become more significant.

While the nature and retrenchment of social citizenship rights can be found in the following chapter, it is important to consider at this point how the ideal and imagination of social citizenship rights are defined by T. H. Marshall as a paradigm shift to rethink and define social citizenship rights as a responsibility of the state and to ensure basic needs to all citizens, according to the standards prevailing in each society. The ideal of social citizenship marks the final stage of development and the ultimate ideal of citizenship for the full participation of the individual in society (Marshall, 1950).

\section{Esping-Andersen's approach}

Gøsta Esping-Andersen is the thinker who has most influenced the categorization and comparison of welfare states. His theory and methodology contribute to the definition and the 
comparison of the different forms of welfare provision. He follows a broader view of the theories of the welfare state, shaped by the political economy approach identified as the "Keynesian Welfare State" or "Welfare Capitalism" (Esping-Andersen, 1990, 1999). The broader view is related to the state's role of managing and organizing the economy and wellbeing while the narrower perspective deals with the amelioration of social risks through income transfers and social services. In The Three Worlds of Welfare Capitalism, Esping-Andersen (1990) identifies the three regime types of welfare states and their most significant characteristics.

Esping-Andersen (1990) proposes the categorization of three different types of welfare states - Liberal, Corporatist and Social Democratic. To situate his framework and methodology for defining and categorizing a welfare state, I consider it important to point out several questions Esping-Andersen raised: How do we know when a welfare state responds functionally to the needs of industrialism or to capital reproduction and legitimacy?; How do we identify a welfare state that corresponds to the demands that a mobilized working class might have?; If welfare states differ, how do they differ?; When is a state a welfare state? What is the welfare state? (EspingAndersen, 1990, p. 18). I have already explained, in part, the rationale for these questions with the discussion of the Marshallian framework on the ideal of social citizenship. For example, they have also been addressed by Arts and Gelissen (2010). For them, "welfare states come in different shapes and sizes and vary substantially in their political orientations and distributional outcomes" (Arts \& Gelissen, 2010, p. 569). Thus, despite some variances, similar patterns and features on the nature of welfare provision and redistribution can be identified across different welfare states.

Esping-Andersen perceived this and offered a framework and methodology to identify and compare the general principles of organizing welfare states across Western industrialized societies (Arts \& Gelissen, 2010; Schroder, 2013). Esping-Andersen (1990) argues that a welfare state 
cannot be understood "just in terms of rights it grants", but should also be understood and taking into account "how state activities are interlocked with the markets and the family's role in social provision" (p. 21). For him, welfare spending, redistribution, and taxation are not enough to define and compare welfare systems. Esping-Andersen considers it even more important to understand and examine what they do and how they do it (Arts \& Gelissen, 2010).

Therefore, Esping-Andersen $(1990,1999)$ establishes three important dimensions to define the nature of welfare provision and its forms of redistribution: (1) the degree of decommodification; (2) the production of welfare; and (3) the kind of social stratification and solidarity that are implied by welfare programs and services. For Esping-Andersen, these dimensions are key to define the nature and degree of public welfare provision and also to classify and compare the different welfare systems. They are consistent with the three criteria to assess the "degree of equalisation" proposed by Marshall's social citizenship framework (Arts \& Gelissen, 2010; Castels, 2010; Marshall, 1950). Moreover, these three dimensions are also an expression of the different forms of welfare provision rooted in different ideological perspectives and theoretical approaches (George \& Wilding, 1985; Williams, 1989, 2016).

The first dimension is the degree of decommodification, the degree to which public welfare provision, either a service or a benefit, is rendered as a matter of right enabling a person to maintain a livelihood without reliance on the market (Esping-Andersen, 1990). In other words, EspingAndersen points to the degree to which an individual can rely on the protection of the welfare state independently of labour market participation. This measures the extent to which a welfare state provides social protection and an acceptable standard of living to its citizens despite the potential loss of job, income, or need for general welfare due to lack of food and shelter, or because of sickness, maternity or paternity leave, disability, etc. It also contributes to assessing the eligibility 
criteria and the proof of means for access to those social citizenship benefits and services (Evers \& Guillemard, 2013; Stephens, 2010). Initially, Esping-Andersen (1990, p. 21) argued that social rights would entail "a decommodification of the status of individuals vis-à-vis the market" (Arts \& Gelissen, 2010; Stephens, 2010). For Evers and Guillemard (2013, p. 6), this interpretation entails a universal right to entitlements in cash or in kind (as services) with no or only minimal conditions. However, as Stephens (2010, p. 513) observes, Esping-Andersen has later clarified that decommodification may not be seen as absolute but it may occur as a variable degree "in which individuals, or families, can upload a socially acceptable standard of living independent of market participation" (Esping-Andersen, 1990, p. 37). Nevertheless, Stephens (2010, p. 513) explains that while not contradictory, there are two different interpretations of the degree of decommodification proposed by Esping-Andersen (1990). The first interpretation assumes that someone has a job and can exit the labour market without income loss. The operationalization and measurement of this interpretation is made through the high-income replacement rates in transfer programs, as the reference criterion for decommodification. The second interpretation does not imply labour market participation as a condition. Stephens (2010, p. 514) observes that this second interpretation is "measured by the benefits provided on the basis of citizenship rather than employment or past insurance contributions." The main criterion is that, "transfers or services would have to be provided equally to each citizen or family on the basis of need" (Stephens, 2010, p. 514).

An important criticism of Esping-Andersen's concept of decommodification is the neglect of the gender dimension (Arts \& Gelissen, 2010; Lister, 2003; Williams, 1989, 2016). According to Stephens (2010, p. 514) among others, the first interpretation made by Esping-Andersen which “assumes the person has a job, is gender biased." Lister (2003) also argues that Esping-Andersen neglects the gender dimension in his analysis. This argument is made from the perspective that the 
right to be commodified is an important goal for women's citizenship rights (Arts \& Gelissen, 2010; Lister, 2003; Stephens, 2010). Moreover, the gender division of paid and unpaid work, in particular care and domestic labour, was not initially acknowledged by Esping-Andersen (Lister, 2003). In this regard, Stephens (2010, p. 514) argues that "the treatment of unpaid work, women's capacity to maintain autonomous households, and the extent to which citizenship (and not employment) is the basis for welfare state claims." This is connected with Williams' (1989) concern with the marginalization of gender. She points out that historically and today welfare policies neglect or marginalize the role of women. Thus, to analyze and categorize a welfare state through the concept and degree of decommodification the gendering of social citizenship rights must be taken in consideration by examining the extent to which a welfare state takes over the issues of gender and some of the caring functions of the family, what Esping-Andersen (1999) calls "defamiliarization" (Stephens, 2010; Williams, 1989).

The second dimension proposed by Esping-Andersen to classify a welfare state is the production of welfare. It consists of the major institutions that provide and guarantee social protection in each welfare state - the state, the market and the family; and how they interact in the production of social welfare (Esping-Andersen, 1990, 1999). Following some criticisms about the neglect of the gender dimension in the Three Worlds of Welfare Capitalism, Esping-Andersen (1999) identified family as the third institution responsible for the production of welfare. He proposed the concept of "defamiliarization" to identify those active welfare policies "committed to lessening the caring burdens of the family" (Esping-Andersen, 1999, p. 45). Williams (2016) explains that through the analytical concept of "defamiliarization", Esping-Andersen (1999) proposed a strategy for moving domestic care work from the household to the state or market in order to "enable women to enter paid employment (to become commodified)" (p. 633). 
Nonetheless, the portrait of this interaction between the state, the market and the family defines the main providers of social protection and influences the degree of decommodification discussed above. However, this production results from different political traditions, and different attitudes to the welfare state (Williams, 1989). Thus, as George and Wilding (1985, p. 1) argue, in order to understand the nature and production of welfare, the social, economic and political system in which welfare operates must be taken into account. Another feature of this dimension is the social welfare provided by civil society and charitable organizations, normally linked with the church or local communities (Arts \& Gelissen, 2010). The interaction between these institutions may result in a public-private mix production of social welfare.

Finally, the third dimension proposed by Esping-Andersen (1990, p. 23) contributes to classify and compare a welfare system through the kind of social stratification and solidarity implied by welfare programs and services. Following Marshall's framework on social citizenship, Esping-Andersen considers that welfare states, through either their programs or services, create and impose an economic and social stratification between the poorest recipients and those that can buy their way out of the system. Thus, this third dimension helps to identify and classify welfare systems based on the degree of class cooperation and redistribution of benefits provided, either by the state, or by corporatist networks involving employers and labour unions, charities and the market. The stratification and degree of solidarity among classes can be identified and measured based on the rights and privileges provided through income distribution, insurance and taxation. These benefits can be either universal, based on social insurance or offered through means-testing (Esping-Andersen, 1990; Evers \& Guillemard, 2013; Iverson, 2010, Marshall, 1950). In fact, these forms of welfare provision represent different ideological perspectives and theoretical approaches that define the relationship between society and the type of welfare benefits provided (George \& 
Wilding, 1985; Williams, 1989, 2016). This third dimension highlighted by Esping-Andersen is also related to the three criteria proposed by Marshall (1950). It aims to assess the "degree of equalization" achieved through the rights of social citizenship: (1) whether the benefit is offered to all or to a limited class; (2) whether it takes the form of money payment or service rendered; (3) whether the minimum is high or low (Marshall, 1950, p. 54). Nonetheless, Esping-Andersen's approach is similar to George and Wilding $(1985)$, and Williams $(1989,2016)$ in that they also look into these different welfare perspectives and classifications. In this regard, Williams (1989; 2016) states that these perspectives have been central to welfare development and thinking. Those conventional classifications comprise the patterns of welfare provision, the existence and understanding of social problems and how to address them.

Hence, those social citizenship programs and services rooted in universalistic and egalitarian principles, and offered without restrictions, are aimed to promote an equality of status without distinction of class. Their redistribution is made through progressive taxation coupled with flat rate benefits. The programs and services provided through social insurance promote and reinforce the protection of wage earners and particular groups of social classes. Its benefits are tied to income and occupation, while means-tested social assistance programs are targeted to the poor based on an individualistic and punitive perspective of social welfare. They offer minimal social protection, mostly to those who cannot meet their basic needs through the market (EspingAndersen, 1990; George \& Wilding, 1985; Iverson, 2010; Williams, 1989).

As I mentioned before, these three dimensions contribute to understanding and determining the nature of welfare provision and its different forms of redistribution in a particular welfare regime. The Three Worlds framework captures how countries can either use the market or diverge from it. Esping-Andersen (1990) identifies the three types of welfare states, according to the three 
criteria mentioned above. The three typologies that result are the Liberal welfare states, the Corporatist welfare states, and the Social Democratic welfare states. These typologies identify a group of welfare states that share similar features persisting over time. It is also important to mention that the categorization of these welfare regime types takes into account both income maintenance and service delivery (Esping-Andersen, 1999, p. 87).

The first welfare state type is the Liberal welfare state, also known as the Liberal AngloSaxon nations' regime. This welfare state regime type is firmly embedded in a belief in individualism and self-reliance. It is also characterized by means-tested social assistance, modest universal transfers and social insurance plans. Benefits are mainly targeted to low-income families and the poorest. The Liberal regime type provides very limited social citizenship rights, creates stratification between those who depend or rely on welfare state benefits and those who can buy their way out, and minimizes decommodification from the markets. In the Liberal regimes, markets remain the central means of allocation, i.e., in countries such as the United Kingdom, the United States, Canada and Australia (Arts \& Gelissen, 2006, 2010; Castles, 2010; EspingAndersen, 1990, 1999; Hay \& Wincott, 2012; Schroder, 2013).

The second welfare state type is the Corporatist welfare state also known as the Conservative Central Europe regime type. This type is characterized by conservative values and the predominance of status differences. Rights are attached to class and status resulting from a degree of class cooperation in the sense of a corporatist network involving both employers and labour unions, although mediated by the State. Thus, benefits are based on the concept of insurance, which offers a negligible equal redistribution among classes and a modest degree of decommodification, meaning that welfare benefits are to some extent tied to the labour-market. Corporatist regimes are also typically shaped by the church and committed to traditional family 
values based on a conservative ideological orientation. For Esping-Andersen, the state only intervenes in this type of regime when the family capacity is "exhausted." It is found in countries such as Austria, Germany, France and Italy (Arts \& Gelissen, 2006, 2010; Esping-Andersen, 1990, 1999; Hay \& Wincott, 2012; Palier, 2006, 2010, 2013; Schroder, 2013).

The third welfare regime type is the Social Democratic welfare state. This regime type is embedded in egalitarian values and marked by a high degree of decommodification and a strong sense of solidarity among classes. It promotes high standards of equality and universalistic programs in an attempt to avoid a dualism between state and market. For Esping-Andersen, this regime type combines welfare and work through a commitment to promote and guarantee fullemployment in order to ensure a right to income to all and also as a way to finance the costs of a universalistic distribution. This regime type is seen in the Scandinavian countries such as Sweden, Norway and Denmark (Arts \& Gelissen, 2006, 2010; Esping-Andersen, 1990, 1999; Hay \& Wincott, 2012; Schroder, 2013, Wood, 2001).

From the foregoing discussion it can be seen now, the Three Worlds framework captures the different varieties of welfare capitalism and how they coordinate and influence the welfare regime types advanced by Esping-Andersen (1990, 1999). Furthermore, as Iverson (2010) explains, each of Esping-Andersen's Three Worlds of welfare capitalism "are associated with a distinct tax-benefit structure. In the most redistributive (Social Democratic) type, progressive taxation is coupled with flat rate benefits; in the Liberal type, means-tested benefits are targeted to the poor; while in the Conservative type benefits are tied to income and occupation" (Iverson, 2010, p. 187).

However, it is important to point out that one of most important criticisms of EspingAndersen's Three Worlds of welfare capitalism is the non-recognition of the Mediterranean 
welfare states (Arts \& Gelissen, 2006, 2010; Ferrera, 1996; Schroder, 2013). According to Ferrera (1996), Italy, Spain, Portugal, and Greece may constitute a separate cluster in the welfare state regime types due to several commonalities. Other scholars go even further by including Cyprus and Ireland in this fourth model (Minas, Jacobson, Antoniou, \& McMullan, 2014).

Ferrera $(1996,2010,2013)$ argues that, the Southern European countries constitute a fourth category - the Mediterranean model. In Ferrera's (1996) account, the welfare states of Italy, Portugal, Spain and Greece can be characterized by four elements: “(1) peculiar 'excesses' in income maintenance: peaks of generosity accompanied by vast gaps of protection; (2) the departure from institutional corporatism in the field of health care and the (partial) establishment of national health services, based on universalistic principles; (3) a low degree of state penetration into the welfare sphere, in a broad sense, and the peculiar mix between public and non-public actors and institutions; and (4) the persistence of clienteles and the formation - in some cases - of fairly elaborate 'patronage systems' for the selective distribution of cash subsidies" (p. 29-30). Within this framework it can be argued that the scope of the social protection system in Southern European countries is not universal, but categorical and work focused. The benefits are calculated on the basis of salary and insurance contributions (Katrougalos \& Lazaridis, 2003). However, Ferrera (1996) emphasizes that this fourth model includes a universal health care system as a basic right of citizenship in force through the Italian, Spanish, Greek and Portuguese constitutions. In response to his critics, Esping-Andersen argued that the Mediterranean welfare regime type is strongly influenced by the issue of familialism. For him, families are "the relevant locus of social aid" (1999, p. 90). Moreover, Esping-Andersen considers that Ferrera's (1996) points are mainly related to the distributive practices rather than with the production of welfare. My aim here is not to argue whether there are three or four welfare regimes but to use Esping-Andersen's $(1990,1999)$ 
framework and methodology to determine and analyze the public provision and redistribution of social citizenship rights. Therefore, this dissertation will not explore the claims in favour or against Portugal surrounding the different welfare typologies proposed by Esping-Andersen (1990) and Ferrera $(1996,2010,2013)$ because such dimensions of analysis do not serve the aims of the research undertaken.

Overall, whether there are three or four regime types, all welfare states have been facing the same dilemmas of retrenchment and transformation, a combination of deindustrialization, the rise of the service sector, and fiscal constraints. I will introduce and discuss the transformation and retrenchment of the welfare state in Chapters V and VI where I will be analyzing the retrenchment of the Portugal welfare state.

In sum, Esping-Andersen's approach speaks to the thesis of this dissertation by defining the criteria that translate the key characteristics to define, analyze and compare the nature and degree of public welfare provision for meeting economic and material needs of different welfare regimes. It also informs the definition of the nature of social citizenship rights addressed in Chapter II and the analysis of the impact of austerity on public welfare provision in Portugal between 2010 and 2014 (Chapter V and VI).

\section{Conclusion}

Since 2008, the politics of austerity have come to dominate the debates surrounding public welfare provision and redistribution in the 21 st century. This new paradigm of austerity has "frozen" the ongoing process of retrenchment of the welfare state that was being carried by national sovereign authorities across Europe and initiated a new phase of cumulative policy 
changes imposed by supra national institutions such as the EU and the IMF or by the so-called financial markets. In Portugal, as I have discussed previously (see Introduction), the austerity measures adopted between 2010 and 2014 were very damaging to the entitlements to social protection (see Chapter V and VI).

In explaining these conceptual frameworks, I sought to provide a thesis and method of analysis that combines and interconnects two theoretical approaches: Marshall's citizenship framework and Esping-Andersen's approach to welfare provision and redistribution. These theoretical approaches are important as they provide the lens and tools that employ a set of perspective attributes that speak to the thesis of this dissertation - the impact of austerity on public welfare provision and redistribution as part of citizenship rights first proposed by T.H. Marshall (1950). As a result, these two theoretical approaches are said to explain the foundations by which to understand the state's fundamental obligations in the maximisation of the principles of social equality, fairness and social justice for all through the rights of social citizenship. They also shed significant light on understanding the process of retrenchment of the welfare state that occurred at the expense of the politics of austerity adopted in Portugal following the 2008 financial crisis.

In the next chapter, I address the emergence of the modern welfare state, and explore its central organising principles by defining and discussing its essential qualities and characteristics as well as the nature of social citizenship rights. At the same time, I explore the different forms of public welfare provision that aim to mitigate or even eliminate the different forms of social and economic inequalities. Finally, I detail and analyze the process of retrenchment of the welfare state under the paradigm of austerity since the 2008 financial crisis. 


\section{Chapter II: The nature of social citizenship rights: definition and reconfiguration}

\section{Introduction}

During the last decades, the study of the welfare state and the analysis of social citizenship rights have evolved into an ideological discourse of welfare retrenchment. To understand and assess the process of retrenchment under the impact of austerity on social citizenship rights in Portugal it is critical to grasp the basic and inherent features of the welfare state. In order to frame the central organizing principles of welfare provision and redistribution, this chapter brings together the theoretical and methodological arguments to inform the definition and analysis of the nature of social citizenship rights, under welfare capitalism in the 21 st century.

Beyond arguing the nature of social citizenship rights, this chapter provides the background about the emergence of the modern welfare state, as well as guidance about the different forms of public welfare provision and redistribution. It also unpacks and explores the components and dimensions of the process of retrenchment of the welfare state and proposes a list of variables to determine the type and degree of retrenchment as a result of the politics of austerity.

Looking through the lens of T.H. Marshall (1950) and Asa Briggs (1961), I adopt a framework that expresses the philosophy of the welfare state centred on the fulfilment of a set of state-guaranteed social and economic provisions. This framework represents the application and operationalization of Fabian values and ideals aimed to modify the negative impact of capitalist market forces on social citizenship rights (George \& Wilding, 1985; Marshall, 1950; Williams, 1989). 


\section{The emergence of social citizenship rights}

The emergence of the modern universal welfare state dates back to at least 1945. It was central in building modern industrial democracies and helping to develop certain ethical, social liberal ideals, like the ideal of social citizenship rights developed a few years later by T. H. Marshall (1950).

The end of World War II (WWII) opened a Pandora's box for a range of new public social programs and services that rapidly became the norm across developed, industrial countries. Previously, social programs and services were provided, but mostly through charities or commercial organizations. The poor were stigmatized as service recipients and not respected as citizens. At some points and in some places, receiving assistance meant giving up many legal rights (Revi, 2014).

William Beveridge is widely considered the founding father of the modern welfare state. William Beveridge's Social Insurance and Allied Services report, published during WWII in November 1942, inspired the British Labour Party to build a comprehensive welfare state program after its election in 1945. In his report, Beveridge proposed a comprehensive reform and extension of welfare provision to defeat what he called the "five giant evils" of industrial capitalism - Want, Disease, Ignorance, Squalor and Idleness (Beveridge, 1942).

WWII led to an increased role for government in the economy. State intervention during the war period and its extension into peacetime sought to promote an effective social and economic recovery (Macintyre, 1999; Revi, 2014). In that sense, the ideal of social citizenship rights clearly underpinned Beveridge's Report. Beveridge's understanding of the operation of markets was also informed by the economics of John Maynard Keynes. Keynes' major work, The General Theory 
of Employment, Interest and Money, was published in 1936, a few years before the war (Keynes, 1936).

The period of economic and social development during and after the Second World War expanded the ideal of social citizenship as a further response by liberal democracies to the extension of individual and political rights in the previous 200 years (Marshall, 1950). Thus, for all these reasons, the thirty-year period between 1945 and the mid-1970s is often characterized as the "Golden Age" of the welfare state, arguably one of modern history's greatest reformist achievements (Esping-Andersen, 1990, 1999; Pierson, 2007).

\section{The nature of social citizenship rights}

The conception of social citizenship rights can be said to originate with T. H. Marshall (1950). He was significant in developing an ideal of social citizenship and reflecting on its nature. The primary aim here is to think about the nature of social citizenship, its essential qualities and characteristics. Such reflection raises significant challenges about which perspectives are or should be incorporated, either ideological or philosophical. The result I aim to explore here represents the tradition of Fabian socialism, which I have already introduced in the previous chapter, as well as the egalitarian ideals of the welfare state.

The modern discourse about the nature and characteristics of social citizenship rights is often influenced by neoliberal and conservative perspectives, embedded in market-oriented approaches. It should be noted however that, here, I am adopting the ideas and language of Fabian socialism to define the nature of social citizenship rights and propose a consistent set of egalitarian programs and services that aim to demonstrate what constitutes the state's fundamental obligations 
in the maximization of social equality, fairness and social justice for all citizens in modern capitalist market societies.

The appeal of Marshall's (1950) ideal of social citizenship, and later corroborated by several contemporary scholars within the same tradition, has been revitalized since the 2008 financial crisis. Social citizenship rights are viewed as a degree of class cooperation and redistribution of benefits provided by the state either through programs or services.

Therefore, the "social" element of citizenship is more than just a category. It represents a direction towards a relationship between the responsibility of the state and the collective needs of the citizens. It is not so much about the "rights", but about the responses to social contingencies translated into public "programs" and "services" to address citizen needs and the inequalities of class caused by capitalism.

Debates about the relation between the state and the collective needs of citizens lie at the heart of the principles of egalitarianism and collectivism. These principles are key to understand the nature of a social citizenship rights framework. In Marshall's account, the ideal of social citizenship represents the egalitarian and collectivist principles of modern citizenship. The extension of civil, political and social rights aimed to move the achievement of social equality forward. Why? Because the modern notion of citizenship proposed by T. H. Marshall brought the enactment of a progressive enrichment of people's equality and social justice.

The idea of egalitarianism is thus central to formulating an understanding of the nature of social citizenship. Egalitarianism is concerned with economic security and redistribution. It aims to remove or reduce class distinctions, and pursue the equality of status, as Marshall proposed. Egalitarian rights are to be viewed as unconditional (Diamond \& Giddens, 2005, p. 106). 
The principles of equality, fairness and social justice are key to egalitarianism and collectivism and translate into a certain vision of society. They work as guiding principles to promote human rights, the rights of citizenship, the meeting of basic needs, social justice and freedom and opportunities for all (Frank, 1997; Spicker. 2006). The principle of equality has been defined in both material and social terms (Cohen, 1997, 2011) and aims to promote an equal share of resources and equal opportunities for all (Frank, 1997; Miller, 1995). This represents what several scholars have defined as equality of opportunity and equality of outcome (Crosland, 1961; Cohen, 1997, 2011; Miller, 1995; Rawls, 1975/2005; White, 1997, 2007; Walzer, 1983). But in a capitalist society that creates and promotes disadvantage and inequalities among classes, egalitarianism and the principle of equality need to be understood and promoted in different ways.

For White (2007, p. 80), the principle of equality aims to prevent and reduce inequalities that are normally attributable to: (1) "brute luck" which is a disadvantage beyond individual control; (2) the "unfair exchange" that results from the potential exploitative effects of the markets, and (3) the "economic free-riding" which may result from the lack of solidarity among classes. This explains exactly the primary importance of the ideal of social citizenship rights proposed by Marshall (1950).

The arguments for equality of opportunity and equality of outcome arise from a society organized and divided by economic and social classes. The ways of pursuing and achieving equality through these two approaches depend upon the interpretations and values of the liberal and socialist traditions (Frank, 1997). Liberalism and, by extension, social liberalism tend to promote equality of opportunity, while socialism aims to address the structural conditions to achieve substantial equality, that is the equality of outcomes (Frank, 1997; Phillips, 1997). However, several other authors consider a third alternative which has been defined as social 
equality or equality of status (Crosland, 1961; Drover \& Moscovitch, 1981; Marshall, 1950; Miller, 1995; Moscovitch, 1981; Spicker. 2006, 2007; Walzer, 1983; White, 2007).

One of the most distinctive forms of equality is its economic dimension. Economic equality is related to the access to and the distribution of material resources of income and wealth in various forms. Moscovitch (1981, p. 58) argues that economic equality "includes four general approaches: equality of opportunity, of outcome, of wealth and equality at work." Moreover, the author explains that equality of opportunity is the predominant ideological conception of economic inequality. Why? Moscovitch (1981) claims that, in the market capitalist society, "equality of opportunity constitutes the negation of equality of outcome, work and wealth" (p. 58). He explains that, "equality of opportunity is the means by which, in capitalist societies, economic inequality is justified" (p. 60). Supporters of equality of opportunity believe that everyone has an equal chance to thrive in society through the material allocation of income and resources (Cohen, 1997, 2011). Its tenets claim that life is a fair competition where everyone starts at the same place (Moscovitch, 1981). This assumption has been pushing people towards high levels of unequal social outcomes on income, employment, health, education, and gender. Equality of outcome, as mentioned above, is what Spicker (2006) defines as the most extreme (or radical) approach to achieve equality. The focus of this approach is in "the end-state - the situation where people finish" (Spicker, 2006, p. 107). For example, it allows for the identification, analysis and comparison of the effectiveness of social policies and resources allocated to substantially reduce or eliminate inequalities. Thus, in order to pursue or achieve an equality of outcome, there needs to be the allocation of rights of citizenship and the provision of resources. To some extent, it favours a great reallocation of resources in order to reduce disadvantage. Equality of outcome also allows for the comparison of people's rights, either individually or by group or class. However, the inequalities and 
contradictions associated with capitalism tend to generate class conflict and social stratification as a result of the relationships with the system of production and system of power (Spicker, 2006).

It is this reasoning that made Miller (1995), among others, argue for an alternative to equality of opportunity and equality of outcome. Miller was concerned with the class divisions in society where social stratification and income inequality were the barriers to achieve the equality of opportunity and outcome. While Cohen $(1997,2011)$ defines equality in material terms, Miller (1995) argues for social equality (or equality of status). This perspective significantly challenged the idea to provide the background conditions for equal access to the market. To ensure that everyone meets their most basic needs as a right of citizenship, equality became linked with the status of citizenship and people's everyday social relationships (Miller, 1995; White, 2007). Social inequality was also labelled by Anthony Crosland in The Future of Socialism in the 1950s (Crosland, 1961). Therefore, social equality refers to an "equality of status" and to the elimination of social disadvantage within society. For all these reasons, Marshall (1950, p. 56) considered that "equality of status is more important than equality of income." For him, the aim is a society where class differences are diminished by social equality and social justice. In Citizenship and Social Class, Marshall's (1950) attempts to explain the opposing principles and contradictions between the development and extension of citizenship and the inequalities of social class. This is why Marshall wondered (1950, p. 9), if "basic equality, when enriched in substance and embodied in the formal rights of citizenship, is consistent with the inequalities of social class?" Then, in Marshall's words, obviously not. This is why understanding the nature of social citizenship becomes even more significant, because it explains not only how Marshall's framework informs this dissertation, but if also explains how the principles of social equality, fairness and social justice establish a commitment to more extensive egalitarian social citizenship programs and services. 
The principles of fairness and social justice also give strength and substance to the nature of social citizenship. John Rawls (1975/2005) in A Theory of Justice has provided an insightful interpretation for assigning the rights and duties of citizenship to the different institutions of society and a way for defining and binding the nature of social citizenship rights to the different forms of public welfare provision and redistribution. Rawls $(1975 / 2005, \mathrm{p}$. 11) affirmed that fairness is the most subjective form of the principles of justice. For him, the "original position" of equality is a hypothetical situation in which people are placed behind a "veil of ignorance" to ensure that no one is advantaged or disadvantaged (Rawls, 1975/2005, p. 11-12), while the conception of social justice is defined as a standard "whereby the distributive aspects of the basic structure of society are to be assessed" (Rawls, 1975/2005, p. 9). Social justice is, therefore, a social ideal that defines and informs a conception of society, a vision of the way in which the aims and purposes of social cooperation are to be understood. Thus, social justice seeks equality and fairness among groups, which represents the ideals of collectivism claimed by the Fabian socialist tradition (George \& Wilding, 1985).

It is these principles to social equality, fairness and social justice - that are the fundamental qualities of social citizenship rights. They pervade Briggs' (1961) ideas about welfare provision through the agency of the state and encompass the ideas and values of Fabian socialism - equality, freedom and fellowship (George \& Wilding, 1985). Finally, it is these principles that lead to the various types of redistribution. They ground and express a clear philosophy of the welfare state directed by an egalitarian and collectivist pursuit of solidarity, fairness and social responsibility in an effort to enact the rights of social citizenship and reduce or even eliminate the various types of class inequality. 
For these reasons, it is important to point out how Asa Briggs (1961) sheds light about the provision of social citizenship through the agency of the state. Briggs (1961) not only establishes the core characteristics of the nature of social citizenship rights, but also extends and operationalizes its programs and services. Therefore, as I have argued above, social equality, fairness and social justice constitute unique components that translate the nature of social citizenship rights into its public provision.

\section{The public provision of social citizenship rights}

Having laid the groundwork about the nature of social citizenship rights, the different forms of public welfare provision will now be explained. This pertains to the redistribution of resources for meeting economic and material needs through the agency of the state. It allows for the definition of an understanding of the state's fundamental obligations in the maximization of the principles of social equality, fairness and social justice for all.

This is why Marshall's social citizenship framework becomes even more significant, because it not only defines the ideals and characteristics of the welfare state, but it also translates the rights of citizenship into a set of programs and services that aim to mitigate or even eliminate the different social and economic inequalities. It also establishes the central organizing principles to measure the public welfare provision and redistribution as part of social citizenship rights.

Therefore, social citizenship rights are translated and operationalized through different programs and services, such as: 1 - Programs to achieve a minimum income (social assistance); 2 - Programs of social insurance, i.e., unemployment, disability and pensions; and 3 - Programs to finance public social services such as housing, education, health care, and personal social services 
(Briggs, 1961). These benefits can be either universal, based on public social insurance or offered through means-tested or fiscal measures (Esping-Andersen, 1990; Evers \& Guillemard, 2013; Iverson, 2010; Marshall, 1950, 1970).

Briggs (1961) described the programs to achieve a minimum income, also known as social assistance, as a minimum threshold income irrespective of the market forces, work or prosperity. This new conception of social protection transformed the prewar system of means-tested relief payments into a universal conception of social protection that came to be the key constituent of the welfare state. These programs of minimum income translated the needs that result from material and social inequalities into rights, and loosened the tie between benefits and contributions (Briggs, 1961; Dean, 2012, 2013; Fraser, 1989; Marshall, 1970; Soper, 1993; Spicker, 1993). Essentially, minimum income benefits are aimed at meeting the most basic human needs - the material living conditions - and maintain and promote the principles of social equality, fairness and social justice, essentially for the individual wellbeing of citizens, according to the minimum standards of living in each capitalist society, as Marshall suggested.

The programs of compulsory public social insurance are one of the main instruments of social policy (Marshall, 1970). They are intended to meet what Briggs calls "social contingencies" and consequently prevent individual and family crises. Those "social contingencies" may include unemployment, a workplace accident, maternity or paternity, an illness, a disability condition, old age as well as the care of children or family members. Thus, programs such as unemployment benefits, disability allowances, maternity or paternity leave and pensions, etc., are public benefits that represent a social security provision based on insurance that enables citizens to withdraw from the market when they face certain needs (Dean, 2012). These programs represent the relevance of the compulsory public insurance principles. The risk of those "social contingencies" mentioned 
above is shared by everyone who works and contributes to the public fund. Those contributions are proportional and based on the income of every citizen. However, as Marshall (1970, p. 49) emphasizes "the nature and basis of rights acquired by the citizen differ according the purpose of the insurance and the kind of risk it is designated to cover." Briggs (1961) emphasized that insurance principles contributed to removing the stigma of pauperism from receiving a social service and facilitated "public approval" for state expenditure. For example, in 1889, Bismarck's Germany became the first to legislate a compulsory insurance scheme. By 1911, Britain had developed centralized old age pensions and compulsory insurance against sickness, unemployment and disability (Revi, 2014). These two blueprints for public social insurance found comprehensive expression in William Beveridge's Social Insurance and Allied Services report published in 1942 during WWII (Beveridge, 1942).

Finally, the programs of public social services - health care, education and housing - are aimed at ensuring that all citizens without distinction of status or class are offered the best standards available in relation to a certain agreed range of social services (Briggs, 1961). This third component of the welfare state brought the ideal of optimum or universalism to all citizens, regardless of their class and income. The provision of public universal health care, primary and secondary education, and social housing aimed to provide an equalizing function among classes, or what Marshall (1950) defined as the equality of status and opportunity. Dean (2012, p. 43) emphasized that health care, education and housing were crucial to tackle three of the five giants outlined by William Beveridge (1942) - disease, ignorance and squalor. The demands brought by the industrialization and by the development of the capitalist economy in the early twentieth century contributed to making considerable progress in the reduction of illness, the treatment of diseases and an increase in life expectancy (Baggott, 2016; World Health Organization [WHO], 
2013). There was also substantial progress in increasing the levels of literacy skills of workers, necessary for thriving in the new capitalist economy (West, 2016). Thus, health care, education and housing are three important conditions of individual wellbeing, necessary to meet the most basic human needs and achieve and maintain a reasonable quality of life. For example, in 1948, following the recommendations of the Beveridge report, the UK launched the National Health Service (NHS) which introduced universal health care services for all citizens. In the aftermath of the Second World War, it is clear that health care, education and social housing were seen as public social services, funded by general taxation and other public mechanisms (Beveridge, 1942; Dean, 2012; Marshall, 1950).

Although Marshall's vision of social citizenship is universal and unconditional in the fields of public health and education services, other social citizenship rights such as programs of minimum income (social assistance) and public insurance (pensions, unemployment and sickness) may be provided or extended conditionally based on entitlement criteria such as prior contributions, age, or means-testing (Evers \& Guillemard, 2013). Marshall's argument is that the state should provide a guaranteed minimum of certain essential goods and services, either universal or conditional to status and eligibility criteria such as age, status, means, past contributions, etc. (Marshall, 1950, 1970).

The principles of distribution - universality or selectivity - constitute an important debate within the enactment of social citizenship rights. Therefore, how does the recognition of rights to social citizenship occur? How are the resources allocated to meet citizen needs? Are these resources to be distributed on the basis of rights to social citizenship? Dean (2012, p. 65) explains "if benefits and services are available on the same basis to everyone, this ensures that everybody is guaranteed the necessary minimum level of help to secure their wellbeing." This represents the 
principle of universality and equality of opportunity on the basis of rights of social citizenship and eliminates the stigma of class inequality attached in meeting those needs. The principle of selectivity has been widely used among the majority of capitalist market societies and it is often the preferred approach since the beginning of the retrenchment of the welfare state. The elective distribution of benefits occurs when the benefits and services of social citizenship rights are only available to those most in need. In other words, the state ensures only minimum levels of social protection.

Social citizenship rights can be also defined on the basis of entitlements to meet certain individual or family needs. In this case, Dean (2012, p. 66) explains that public resources "are allocated in accordance with a system of rules or a legal framework on the one hand, or at the discretion of expert administrators and professionals on the other." Moreover, Dean emphasizes that, when the access to public resources is governed on the basis of entitlements, the allocation of rights of social citizenship is predictable, accurate and effective. Thus, as I discussed above, this ensures that needs and inequalities are interpreted and translated into clear rights and not merely interpreted or satisfied on the basis of professional or bureaucratic discretion (Fraser, 1989; Lister, 2010).

Undoubtedly, these programs and services of public welfare provision and redistribution are aimed to promote the principles of equality, fairness and social justice as rights of citizenship, either through the material allocation of income and resources in various forms or through the delivery of welfare programs and services (Frank, 1997; Miller, 1995; Spicker. 2006; White, 2007). 


\section{The reconfiguration of social citizenship rights}

Debates about the retrenchment of the welfare state are embedded in a complex web of ideological, economic and fiscal events and ideas that resulted from the triumph of neoliberalism and its market-oriented rationale in the late 1980s. The fall of the Berlin Wall, the collapse of Communism and the growth of the "Tiger" economies in Southeast Asia initiated a new era of capitalist expansion (Ferguson, Lavalette, \& Mooney, 2002). This contributed on the one hand, to an increase in the accumulation and concentration of wealth and, consequently, the rise of inequality between the rich and the poor. On the other hand, it also led to the beginning of the reconfiguration of the welfare state across Western industrialized economies (Evers \& Guillemard, 2013; Ferguson et al., 2002; Ferguson et al., 2018; Gilbert, 2013; Harris, 2014; Pierson, 2001).

Several scholars have hypothesized about the pressures towards the retrenchment of the welfare state. Structural factors such as globalization, deindustrialization, the maturation of the welfare state, the rise of unemployment, demographic shifts, family instability, changes in gender roles in labour markets and households, and the introduction of new technologies in the labour market, have led to severe constraints on the rights of social citizenship (Esping-Andersen, 1999; Evers \& Guillemard, 2013; Ferguson et al., 2002; Gilbert, 2013; Lister, 2003: Pierson, 2001; Taylor-Gooby, 2004). For example, the demographic shift like the aging of the population, are one of the most dramatic structural changes that have been causing pressure for more demands on social spending (Gilbert, 2013). Mishra (1993) and Leonard (1997) have also identified these factors. They argued that full employment, universality and increasing equality can no longer be sustainable in Western societies. They claimed that those key features of the welfare state were no longer appropriate in a global capitalist economy. Mishra (1999) also argued that globalization curtailed the policy autonomy of nation states by forcing significant changes in labour market, 
taxation, social spending and public social protection system. By the 1990s, global capitalism pushed for an increasing role of the market economies, imposed cuts to social wages, demanded flexibility in the labour market and lower taxes, introduced competitiveness, and influenced privatization and consumption (Ferguson et al., 2002; Palier, 2006; Pierson, 2007). Thus, the retrenchment of the welfare state is a direct consequence of the conditions created by neoliberalism - capitalist free market economy, globalization and privatization of public services (Harvey, 2005, 2010a, 2010b). Harris (2014, p. 8) has argued that "neoliberalism's priority is the creation of conditions attractive to capitalist profitability in the global market."

According to Ferguson, Ioakimidis, and Lavalette (2018, p. 24), all the changes mentioned above since the 1980 s represent the "retreat of the state." The terms "retreat", "retrenchment" and "reconfiguration" are used to describe and explain the same process to withdraw from public welfare provision. Here, the term "retrenchment" is being used to define the process of reconfiguration (transformation) of social citizenship rights. Therefore, following Ferguson's et al. (2018, p. 24-25) ideas, retrenchment represents the process by which the state is "contracting out welfare services to private providers, non-governmental organisations (NGOs), or simply withdrawing from areas of provision." Similarly, Pierson (2001) defined the retrenchment in the welfare state or re-commodification of needs. Pierson argued that OECD countries have been promoting a recommodification of needs which constitutes the effort to reverse the process of decommodification proposed by Esping-Andersen (1990, 1999). Pierson's (2001) discussion is about restrictions on participation in the labour market, changes in the eligibility to access different social welfare benefits, cuts in social programs and the dismantling of aspects of the welfare state (p. 422). 
Therefore, the role of the state towards social welfare has shifted from that of providing benefits that compensate for individual needs to ones that enable citizens to actively exercise responsibility in coping with those social risks and inequalities (Pierson, 2001; Taylor-Gooby, 2004). Consequently, the erosion of entitlements of social citizenship in place since the 1990s and the evolution of the welfare state towards the "enabling state" have depleted the nature and scope of social citizenship rights in all Western OECD countries (Evers \& Guillemard, 2013; Gilbert, 2013).

The term "enabling state" illustrates the process of retreat, retrenchment and reconfiguration that has been mentioned above. Thus, "enabling state" represents "the tenet of public support for private responsibility, where 'private' responsibility includes individuals, the market and voluntary and charity organizations" (Gilbert, 2013, p. 85). This has been the current paradigm that led to the gradual reconfiguration of the rights of social citizenship. For Gilbert (2013), the retrenchment (transformation) of the welfare state can be grouped into four critical dimensions - privatization, promoting work (known as workfarism), selective targeting and social obligations of citizenship. Streeck also explains that "these reforms represented an almost universal restructuring of national welfare states in the direction of investment rather than consumption, re-commodification instead of de-commodification, strengthening 'employability' instead of raising workers' reservation wage, activation for the market instead of protection from it" (as cited in Gilbert, 2013, p. 86).

With this foregoing discussion in mind, the analytical and theoretical perspectives developed in this Chapter and in Chapter I are now applied to create a detailed analysis of the process of retrenchment of the welfare state in Portugal under the paradigm of austerity since the 2008 financial crisis. Thus, the 2008 financial crisis produced a social crisis caused by the adoption 
of bold austerity measures which represented a paradigm shift for welfare capitalism. This shift has resulted in a severe curtailment of the rights of social citizenship, so the process of retrenchment deepens.

It is this reasoning that explains the need for analyzing the "new" paradigm of austerity in the process of retrenchment of the welfare state. In order to investigate this "new' paradigm, it is important to determine the components and dimensions of retrenchments proposed by Ferguson et al. (2018), Pierson (2001), and Gilbert (2013). The combination of these retrenchment components and dimensions will contribute to assessing the nature of welfare provision and its forms of redistribution (both programs and services) discussed in the previous chapter: (1) the degree of decommodification; (2) the production of welfare; and (3) the kind of social stratification and solidarity that are implied by welfare programs and services (Briggs, 1961; Esping-Andersen, 1990; Marshall, 1950).

\section{Measuring the retrenchment of social citizenship rights}

In Chapter I, I introduced Marshall's (1950) conceptualization of social citizenship to define the central organizing principles in the development of the welfare states and the role of the state in welfare provision and redistribution as part of citizenship rights (Briggs, 1961; EspingAndersen, 1990; Marshall, 1950). In that chapter, I also discussed the fulfillment of a set of stateguaranteed social and economic provisions (Briggs, 1961; Esping-Andersen, 1990; Marshall, 1950). In order to analyze the retrenchment of the welfare state under the paradigm of austerity, I also explored the ongoing process of retrenchment of the welfare state in Western capitalist market economies (Ferguson et al., 2018; Gilbert, 2013; Pierson, 2001). 
I consider that, by combining the retrenchment components proposed by Ferguson et al. (2018), Pierson (2001) and Gilbert (2013), the necessary variables are established to identify and analyze the retrenchment of Portugal's welfare state under the impact of that country's austerity measures adopted between 2010 and 2014. These retrenchment variables contribute also to the determination of the "degree of equalization" defined by Marshall (1950) and the type and degree of welfare provision and its forms of redistribution proposed by Esping-Andersen (1990).

The development of such variables contribute to assess the impact of the key elements of retrenchment on both social citizenship programs and services. These variables are intended to determine the influence of the impact of austerity measures on the process of retrenchment of the welfare state in Portugal. These variables are also aimed to assess only the decommodified provision of social citizenship rights - the welfare provisions offered by the state (EspingAndersen, 1990; Ferguson et al., 2002). I am particularly interested in variables that translate the retrenchment imposed on the access to the distribution of material resources of income (cash benefits). As discussed earlier in this chapter, focusing the analysis of retrenchment under the paradigm of austerity on cash benefits allows us to determine how the state promotes two of the

most distinctive forms of equality, the economic and the social type (Cohen, 1997, 2011; Marshall, 1950, 1981; Miller, 1995; Moscovitch, 1981).

\section{The retrenchment variables}

The variables being proposed in Table 1 are fully conceptualized with a basis in theory and research, as mentioned before in this chapter (Esping-Andersen, 1990; Ferguson et al., 2018; 
Gilbert, 2013; Marshall, 1950; Pierson, 2001). They are almost all observable through policy analysis; the variable on Portugal's social spending draws from OECD secondary.

Table 1 outlines four variables that draw on the retrenchment construct components proposed by Ferguson et al., (2018), Gilbert (2013) and Pierson (2001). They are aimed to reflect the demands imposed by financial markets, following the 2008 financial crisis, and which have brought new challenges to welfare states in Europe - the so-called "market justice."

\section{Table 1 - The Retrenchment Variables}

\begin{tabular}{ll}
\hline Variables & Retrenchment Components \\
\hline $\begin{array}{l}\text { Social Spending } \\
\text { (Total and Per Program) }\end{array}$ & Cuts in social programs and services \\
\hline Eligibility Criteria & Changes in the eligibility to access programs and services \\
\hline Withdraw & $\begin{array}{l}\text { Dismantling aspects of the programs or contracting out services to private } \\
\text { providers and NGO's }\end{array}$ \\
\hline Restrictions & $\begin{array}{l}\text { Conditions introduced on the coverage, duration and generosity of programs and } \\
\text { services, i.e. selective targeting, social obligations, promotion of work, etc. }\end{array}$ \\
\hline
\end{tabular}

Sources: Esping-Andersen, 1990; Ferguson, Ioakimidis \& Lavalette, 2018; Gilbert, 2013; Marshall, 1950; Pierson, 2001.

Thus, the variables proposed are in line with my aims to reflect the financial crisis, the role of the markets and the dynamics of austerity that introduced a new stage in the neoliberal process of retrenchment (recommodification) of social citizenship rights. They translate the key retrenchment components aiming to determine the influence of the politics of austerity in the process of retrenchment of the welfare state in Portugal, between 2010 and 2014. They test and operationalize the retrenchment hypothesis defined by Ferguson et al. (2018), Gilbert (2013) and Pierson (2001) to assess the "degree of equalization" proposed by Marshall (1950) and the degree of decommodification of public welfare provision, as defined by Esping-Andersen (1990). 


\section{Conclusion}

A framework to understand the nature of social citizenship rights has now been proposed and discussed. As explained earlier in this chapter, the adopted conception draws on the principles of equality, fairness and social justice as fundamental qualities of the nature of social citizenship rights. These principles it has been argued inform and define the nature of social citizenship, as defined by Marshall (1950). The rights to social citizenship were developed and conceptually based on principles that represent the application and operationalization of Fabian values and ideals, essential to ensure that the principles of equality, fairness and social justice are established and met (George \& Wilding, 1985).

As explanation has also been offered why social and economic equality represent Marshall's (1950) egalitarian principles of modern citizenship. Despite the critiques about the Marshallian framework, it is argued that, in the 21 st century, the social citizenship framework is more inclusive and it defines the rights to the meeting of needs of all citizens, despite their culture, faith, race, gender, education level, social class, income, ideology, and so on.

This chapter has also explored the principles of distribution of social citizenship rights. It has looked at the ways in which the recognition of rights to social citizenship occurs, how the resources are allocated to meet citizen inequalities and needs, and how these resources are or can be distributed on the basis of rights to social citizenship.

Finally, to reflect the reconfiguration of the welfare state as the current paradigm for social protection, this chapter has also discussed the process of retrenchment of social citizenship rights. In contrast to the egalitarian ideal of social citizenship, it has illustrated the key dimensions and 
variables to evaluate the retrenchment of the welfare state under the impact of the austerity measures that have been adopted in the majority of OECD countries. 


\section{Chapter III: The rise the Portuguese welfare state (1974-1996)}

\section{Introduction}

Social citizenship rights in Portugal have undergone significant changes since they were established after the 1974 democratic Carnation Revolution. The late development of the Portuguese welfare state pushed the country into its own era of welfare expansion when compared to the Golden Era of the post World War II welfare state developed by other western democracies.

The establishment of the modern and democratic welfare state in Portugal in 1976, and consequently, the gradual development and consolidation of social citizenship rights since then, has been characterized and influenced by several stages and factors (Ferreira, 2005). The early analyses of the welfare state in Southern-European countries like Portugal were initially characterized by identifying and comparing their rudimentary characteristics of social protection systems with other developed European economies like the UK, France, Germany and Sweden among others (Ferrera, 1996).

The 1974 Carnation Revolution was the beginning of a process that led Portugal to join the former European Economic Community (the current European Union) in 1986. From absence and ineffectiveness of social citizenship rights, Portugal made progress to develop a comprehensive set of social citizenship rights that culminated with the introduction of a minimum income program (called RMG) in 1996. During its first twenty years, the Portuguese welfare state offered a mix of social protection, universal social citizenship rights that included public health care and education; and income maintenance of cash benefits - old-age pensions and unemployment insurance. Material needs for the most vulnerable were mainly provided by non-public charitable organizations with ties to the Catholic church which, in part, was creating significant gaps in the 
rights of social protection, already discussed in the previous chapter (Briggs, 1961, Ferreira, 2005; Ferrera, 1996).

Such characteristics of class-cooperation where cash benefits were, in the early years, tied to income and occupation placed Portugal closer to the Bismarckian tradition of type-benefits (Esping-Andersen, 1990, 1999; Ferrera, 1996; Schroder, 2013). With a modest degree of decommodification, social citizenship rights were mostly attached to status (Esping-Andersen, 1990, 1999; Marshall, 1950). The impossibility of a fully developed welfare state, in such a short period of time, created a dichotomy with the beginning of the new wave of welfare retrenchment initiated in the 1980s, in most of the advanced capitalist economies. The beginning of welfare retrenchment in many of the western democracies during the 1980 s created a rift between them and Portugal - one group of countries cutting back on social spending while Portugal was still seeking to consolidate its social protection system under democracy. This is especially important in light of the characteristics of the "debt states" highlighted by Streeck (2014). While Portugal embraced the new wave of capital liberalization, the weakness of the Portuguese economy and the rise of public debt due to the gap between tax revenues and public expenditure, created the perfect conditions to accelerate the process of European integration. This process to some extent, contributed decisively to the development and stabilization of the Portuguese welfare state after joining the European Economic Community (Ferreira, 2005; Ferrera, 1996; Guillén, Álvarez \& Adão e Silva, 2003). Unlike most welfare states, the Portuguese welfare state began the process of welfare retrenchment with the introduction of activation policies (strengthening "employability" and social obligations of citizenship) in 1996 with regards to social assistance (minimum income) and several other reforms in its social security system (Arcanjo, 2011; Batista \& Cabrita, 2009; Branco, 2001; Ferreira, 2005; Guillén et al., 2003). 
This chapter explores the key and most significant events in Portugal from the creation of its universal and democratic public welfare state in 1976 to the reform of the Social Security System in 1996 that introduced the Guaranteed Minimum Income (Rendimento Mínimo Garantido). It begins by contextualizing and detailing the 1974 Carnation Revolution in order to explain the historical, economic and cultural background behind the creation and extension of social citizenship rights in Portugal. The chapter then analyzes the economic and political factors prior to and after Portugal joining the EU (the former EEC) in 1986 that facilitated both development and retrenchment of the welfare state. It concludes by exploring the political and European factors that led to the adoption of a new framework for social protection in Portugal, resulting in the introduction of a Guaranteed Minimum Income (GMI) (Rendimento Mínimo Garantido) program in 1996.

\section{The democratic revolution of 1974}

On April 25, 1974, a military coup conducted by the Armed Forces Movement (MFA), a military left-wing movement within the Portuguese Armed Forces, ended forty-eight years of dictatorship. According to Guillén, Álvarez, and Adão e Silva (2003, p. 255), "the abrupt end of the Estado Novo with the Carnation Revolution of 1974 represented a radical path shifting in all fields of Portuguese society." On that day democracy began, millions of people walked into the streets of Lisbon without military permission. The occupation of the streets marked the beginning of a revolutionary process (PREC) that lasted 19 months (Bastien, 1993; Birmingham, 2003; Santos, 1984, Varela, 2011; Varela \& Guedes, 2011). 
The Revolution led to a process of social and economic reforms - widespread nationalizations, agricultural reforms, increasing of wages, reforms of old-age pensions and unemployment insurance, creation of public free health care and education services, and programs of social housing (Cardoso, Santos, Baptista \& Clemente, 2012; Guillén et al., 2003; Varela, 2011, 2015).

The post-Carnation revolution period was characterized by radical social protests that included strikes, rallies and housing or workplace occupations. These social conflicts occurred between May 1974 and November 1975, a period known as PREC (Processo Revolucionário em Curso). Varela (2015) explains that PREC had episodes of social conflict and protest involving about 3 million people out of a population at the time of 9 million. During that period, Portugal had six governments composed of communists, social democrats and liberals, and three attempted coups (Birmingham, 2003; Santos, 1984; Varela, 2011, 2015).

The first provisional government was established on May 16, 1974, a popular coalition composed of communists, socialists and social democrats. Despite the variety of new democratic political forces composing the first democratic government, the streets were flooded by workingclass people demanding an increase in wages. The workers' movements were demanding minimum wages between 4000 and 6000 escudos, but the government only approved 3300 escudos (Cabral \& Soromenho-Marques, 2014; Varela, 2011, 2015).

The months that followed the revolution until the end of 1975 were characterized by radical ideas and demands. Minimum wages increased from 3300 Escudos in April 1974 to 4000 in April 1975. Other measures were adopted by the interim government, such as the regulation of food prices, as well as intervention in more than 300 factories in order to secure the jobs and to ensure continuing production. The transitional government also increased all wages, passed a bill that 
introduced a thirteenth and fourteenth monthly salary (a bonus of two more per year) and introduced, by law, the concept of a collective work agreement to all workers (Ferreira, 2005).

The Carnation Revolution also introduced and extended new social citizenship rights maternity, child, sickness and disability benefits. It allowed for the introduction of a public unemployment insurance program and public pensions for which all workers would be eligible (Cabral \& Soromenho-Marques, 2014; Cardoso et al., 2012; Guillén et al., 2003). A universal health care service and a social housing program were both created during this same period. Regulation of housing rents and of essential food items was also established (Varela, 2011, 2015; Varela \& Guedes, 2011). Another example is the educational system; before 1974, education was only available to the elites. According to Varela and Guedes (2011, p. 76) in 1975, 26 per cent of the population was illiterate and 85 per cent of the children between 6 and 10 years old were only able to complete primary education. The revolution and people's demands changed everything in the education system. The new regime introduced a new curriculum, improvements in working conditions for teachers and other staff members, they created a school transportation network, and built new schools, cafeterias and residences. School bursaries were also created and distribution of milk in the schools was also implemented (Cabral \& Soromenho-Marques, 2014; Varela. 2015; Varela \& Guedes, 2011).

The revolution brought the opportunity for members of Portuguese society to participate at all levels of public decision-making. Decisions were proposed and discussed in worker assemblies. During the transition period, the right of public assembly, to strike, to constitute political parties and labour unions and even to occupy factories, all were publicly accepted, despite the lack of legal changes (Varela, 2011, 2015; Varela \& Guedes, 2011). 
Arguably, the democratic revolution opened the doors to the development and extension of citizenship rights. Following the revolution, the demands of the working classes were visible through the increasing number of strikes in the industrial and service sectors. According to Varela and Guedes (2011, p. 76), in the first five weeks following the revolution, 97 strikes took place and 15 were attempted. These strikes were decided on and approved by democratic workers' assemblies in each office and factory. The workers' demanded the introduction of additional 13th and 14th monthly pay cheques (a bonus of two more per year), higher minimum wages, employees with stock ownership and employee-owned companies (Bastien, 1993; Varela, 2015). Varela and Guedes (2011, p. 76) explain that the demands made by workers were deeply shaped by universal and progressive ideals of equality for all.

In sum, the Carnation Revolution represented an unprecedented moment of worker's control and disruption. According to Varela (2015, p. 155), four main reasons explain the rupture of the regime: the military defeat of the regime's regular army; the international economic crisis of capitalism that began in 1973; the role of the worker's movement; and the absence of democratic labour unions. Consequently, the Revolution led to the enactment of comprehensive social citizenship rights from universal public health and social security systems, to affordable housing and free public education, which confirms Briggs (1961) and Marshall's (1950) definition about what constitute the public provision of social citizenship programs and services.

\section{The design of the Portuguese welfare state}

The Portuguese welfare state came into reality in 1976 with the approval of the new democratic Constitution on April 2 (Ferreira, 2005, Ferrera, 1996; Rodrigues \& Silva, 2016; 
Tribunal Constitucional [TC], 1976). The revolution of 1974 aimed to introduce a comprehensive and universal welfare state rooted in communist and socialist ideals. As it has been shown previously, Portugal was late in developing democratic citizenship rights. The three types of elements or sets of rights of citizenship in western industrialized democracies, civil, political and social rights, did not occur there in an historical progression as identified by Marshall (1950). Rather, civil, political and social rights were acquired through an indivisible bundle of publicly accepted democratic citizenship rights, following the 1974 revolution. As Ferrera (1996, p. 23) emphasized, "Portugal formally jumped from occupation to universal coverage in 1976." Thus, Portugal's example confirms Marshall's (1950) thesis - the enactment, extension and protection of the rights of citizenship (civil, political and social) to the working classes are at the core of social democracies.

Ferreira (2005) explained that the development of the Portuguese welfare state in the postrevolutionary period deeply influenced future developments and citizen demands since then. The highly volatile, democratic political regime with several new political forces on the one hand and the radical demands of the working-class people on the other led to a conflict between two different and opposing visions of society - a social democratic, western European political project and a socialist project. As a result, the visions being proposed for the welfare state were between a Bismarckian corporatist model and a more universalistic model inspired by Fabian socialist ideals (Briggs, 1961; Ferreira, 2005; Ferrera, 1996; Marshall, 1950; Varela, 2016).

In that sense, the democratic Constitution of 1976 aimed to create the necessary conditions to stabilize the class conflicts and the political instability which occurred over the PREC period (1974-76). For example, the introduction of the 1976 Constitution confirmed the fact that the revolution restored the fundamental rights and freedoms of the Portuguese people. Further, it 
aimed to defend Portugal's sovereignty and to guarantee the fundamental rights of its citizens, to establish the basic principles of democracy, to ensure the democratic rule of law and to create conditions for a socialist society (Rodrigues \& Silva, 2016; TC, 1976). Article 1 (Portuguese Republic) defined Portugal as a sovereign republic that aimed to promote "class abatement", which for Marshall (1950) meant, "diminish class differences", while article 2 (Democratic state and transition to socialism) identified Portugal as a democratic state that respects and guarantees fundamental citizenship rights and aims to create conditions for a transition to socialism that ensures the democratic exercise of power by the working classes (TC, 1976).

Varela and Pereira (2015, p. 22) argue that citizenship rights and the establishment of a universal welfare state occurred through a revolutionary process and not by evolution from a corporatist, charitable and dictatorial state to a democratic state. Thus, the 1976 Constitution is commonly viewed as a social pact that defined and bounded the role of the state, its responsibilities and commitments towards democracy and citizens, the relation with society and between the different class interests (Branco, 2003; Ferreira, 2005; Rodrigues \& Silva, 2016; Varela, 2016; Varela \& Pereira, 2015). Thus, civil, political and social citizenship rights were enacted through this Constitution (TC, 1976).

According to Varela (2016, p. 278), the Constitution aimed to establish permanently the foundational basis of the welfare state through the transfer of income from capital to labour and through the creation of public and universal social citizenship rights - education, healthcare, public social insurance protection through pensions and unemployment insurance, and social housing (Briggs, 1961; Marshall, 1950; Rodrigues \& Silva, 2016; TC, 1976; Varela \& Pereira, 2015). For example, Article 51 stated that all citizens have the right to work and Articles 52,53 and 54 enacted several labour rights and the state's responsibility to protect workers from exploitation and 
discrimination. Articles 63, 64 and 65 introduced public and universal social citizenship rights for all citizens - social protection (Article 63), health care (Article 64) and social and affordable housing (Article 65). In addition, Articles 68, 69, 70, 71 and 72 enacted the rights to and services for maternity, children and youth, people with disabilities and older adults. Articles 73, 74 and 76 introduced the right to free and universal public education (Briggs, 1961; Ferreira, Carolo, Pereira, \& Silva, 2016; Marshall, 1950; TC, 1976).

However, some social citizenship rights were immediately introduced or extended after the 1974 revolution. Branco (2003, p. 158) observes that the universal old-age pension was immediately introduced on May 1974 through the Decree-Law n. 217/74, of May 27 (entered into force in July 1974). This type of old-age pension (pensão social) was a non-contributory social pension for citizens who had never paid insurance premiums (Cardoso et al., 2012). It was granted based on citizenship status. Despite the small percentage of the population being covered by this non-contributory old-age pension, Branco (2003, p. 158) argues that it was the first major social citizenship right being granted after the 1974 revolution. In 1977, the coverage and eligibility of this non-contributory old-age pension (pensão social) was extended to people with disabilities who were 14 years of age or older and to disabled older adults in residential care homes (Cardoso et al., 2012). In 1979, the non-contributory old-age pension became part of the minimum schemes of the new Social Security System (Sistema de Segurança Social) (Branco, 2003; Cardoso et al, 2012).

The National Health Care System (Sistema Nacional de Saúde, also known as SNS) was also "officially" introduced in 1974, assuming the transference of the "Medical Social Services" that existed before the 1974 revolution (Mozzicafreddo, 1991). The National Health Care System was later enacted as a universal and free citizenship right by the 1976 Constitution (TC, 1976). For example, according to Mozzicafreddo (1991, p. 66), in 1970 only 56 per cent of the population 
was covered by health care services, while in 1976 the coverage reached 100 per cent of the population.

However, Ferrera (1996, p. 23) explains that after the revolution Portugal maintained the pre-existing compulsory insurance schemes. The National Health Care System remained a dual structure. On the one hand, public servants maintained privileged access to and levels of health care services, tax credits and deductions due to their special public insurance schemes, while on the other hand, the most vulnerable citizens - older adults, people with disabilities, children, immigrants who returned from the former colonies and the unemployed and poor people had only the newly created National Health Care System. The introduction of public universal health care services was a significant departure from the corporatist model of Salazar's regime (Branco, 2003; Ferreira, 2005; Ferrera, 1996; Varela, 2016; Varela \& Pereira, 2015). Education and housing were also enacted as social citizenship rights after the 1974 revolution, even before the approval of the 1976 Constitution. The public education system became free and provided universal access from primary school to university while social housing became a citizenship right (Varela, 2016). Nevertheless, it is important to understand between the rights of social citizenship enacted by the 1976 Constitution, the traditions and ideals behind them, and what they mean for the development of the Portuguese welfare state. According to Ferreira et al. (2016), a close analysis of the Constitution of 1976 shows that, despite the enactment of an extensive bundle of social citizenship rights for all citizens, it is clear that, the creation of the Health Care System (SNS) and the investment in the public Education System were following a socialist or social-democratic tradition - both universal, free and unconditional (Briggs, 1961; Ferreira et al., 2016; Marshall, 1950; TC, 1976). 
Regarding the social security system and the rights to social protection, Ferreira et al. (2016, p. 74) argue that, Article 63, n. 4 (TC, 1976) emphasizes eligibility based on earnings from employment which points to a more corporatist and conservative state, i.e. unemployment insurance. Therefore, Ferreira et al. (2016, p. 74) claim the Social Security System enacted by the 1976 Constitution was rooted in the Bismarckian model, which provided social protection only for those who paid premiums. Thus, the 1976 Constitution did not grant unconditional social citizenship rights to social assistance. As a result, Ferreira et al. (2016, p. 74) believe the 1976 Constitution rejects the universality of social citizenship rights and diminishes the responsibility of the state to guarantee social protection for all citizens. In addition, the authors refer to two other important reasons that justify such claims. One is the fiscal redistribution of taxes and credits, which according to the Constitution of 1976, aimed to equally distribute the wealth and surplus among classes and those most in need (Article 106, n. 1). Another example is the importance given by the new Constitution to charitable organizations (Article 63, n. 3) with ties to the Catholic Church, and influenced by conservative Democratic-Christian values (TC, 1976). These two examples highlighted by Ferreira et al. (2016) point to a mix of social protection, non-contributory, universal public health care and education on the one hand and, on the other hand, insurance-based welfare benefits and services. Social citizenship rights were, to some extent, tied to income and occupation. The explicit reference to charitable organizations in the Constitution of 1976 demonstrates that significant gaps of social protection had to be filled by charitable organizations and other organizations in civil society (Ferreira et al., 2016).

Ferrera (1996) defined the Portuguese welfare state as a departure from corporatist principles in the field of health care, as a result of the universalistic principles of the National Health Care System. Moreover, Ferrera (1996) also emphasized Portugal's welfare mix between 
public social services and non-public charitable organizations, which confirms Ferreira's et al. (2016) claims. According to Esping-Andersen, in "Conservative" or Bismarckian welfare state models, benefits are tied to income and occupation. There is a degree of class cooperation involving both employers and labour unions. Corporatist regimes are typically shaped by the church, based on a conservative and Democratic-Christian orientation to the family (EspingAndersen, 1990, 1999; Ferrera, 1996; Hay \& Wincott, 2012; Iverson, 2010; Palier, 2006, 2010a, 2010b, 2013; Katrougalos \& Lazaridis, 2003; Rhodes, 1996; Schroder, 2013).

As a result of the dichotomies in the 1976 Constitution, the Decree-Law n. 513-L/79 of December 27, 1979, introduced a minimum income protection scheme which included different programs such as unemployment benefits, old-age security pensions, guaranteed income pension supplement, child benefits, mothers allowances and disability benefits intended to provide social assistance and income support for citizens in need (Branco, 2003; Ferreira, 2005; Varela, 2016; Varela \& Pereira, 2015). The new bill aimed to extend universality and the degree of decommodification of social citizenship rights to all citizens.

Internationally, the 1970s marked the end of postwar reconstruction and the breakdown of the international monetary system leading to the fall of the political and Keynesian post-war socioeconomic order (Streeck, 2013, 2014). The late move towards democracy left the Portuguese welfare state in limbo and in a counter cycle with the major western industrialized economies who faced massive inflation, a rise of unemployment, and a phenomenon called "stagflation" (Blyth, 2013).

In Portugal, the Carnation Revolution of 1974 and the demands for democracy led to economic and social development and to the extension of civil, political and social citizenship rights, which increased significantly Portugal's social expenditures (Table 2), from 2\% of GDP in 
1974 to $3.6 \%$ in 1975 and $2.8 \%$ in 1976 (as a percentage of GDP). Consequently, social expenditure on education, public health care and social security increased significantly to $5.5 \%$ of GDP in 1977, 6.7\% of GDP in 1978 and $7.3 \%$ of GDP in 1979.

Table 2 - Portugal's Public Social Spending as a \% of GDP (1973-1979) ${ }^{1}$

\begin{tabular}{ccccccc}
\hline 1973 & 1974 & 1975 & 1976 & 1977 & 1978 & 1979 \\
\hline 2 & 2 & 3.6 & 2.8 & 5.5 & 6.7 & 7.3 \\
\hline
\end{tabular}

Source: PORDATA, 2018, retrieved from www.pordata.pt

However, three years after the democratic revolution of 1974, inflation and economic and fiscal constraints forced Portugal to request its first bailout loan to IMF (1977-1978). Portugal received financial assistance from the IMF, in the total amount of US\$158 million dollars (at current exchange rates) (IMF, 2017).

\section{The 1980s: The neo-liberalization of the Portuguese welfare state}

Aiming for European integration pushed Portugal into a new phase of economic and political reform. The 1980s marked the beginning of austerity policies and structural reforms in order to meet the adhesion criteria required for membership in the European Community, which were discussed between Portugal and the Commission of the European Communities between 1977 and 1979 (European Communities Commission, 1978a, 1978b, 1979; Eur-Lex, 1978, 1979; Guillén et al., 2003).

\footnotetext{
${ }^{1}$ Table 2 only includes Portugal's public expenditure on Education, Health Care and Social Security (1973-1979).
} 
The extension of social citizenship rights that occurred in 1979 through the creation of a universal minimum income scheme did not last long. In 1980, the Decree-Law n. 160/80 of May 28 , suspended the universal minimum income scheme and replaced it with a more restricted noncontributory scheme within the Social Security System (Monteiro, 1998). According to Monteiro (1998, p. 268), those changes represented the reversal of the Keynesian-oriented and universal social citizenship rights program adopted in 1979 and a return to the Bismarckian tradition typebenefits adopted in 1974, which privileges participation in the labour market. The new social assistance scheme introduced a more restricted means-testing program, with several eligibility conditions for those not covered under the insurance programs (Monteiro, 1998). Thus, the early 1980s represented the design and consolidation of the Portugal welfare state as one within the "corporatist welfare state" tradition with a high degree of class cooperation, a modest degree of decommodification, as social citizenship rights were again attached to status. The introduction of means-testing brought the scheme more into line with the Anglo-American model. It forced the most vulnerable to rely on family compassion and charity (Esping-Andersen, 1990, 1999; Ferrera, 1996; Monteiro, 1998; Schroder, 2013).

Thus, the 1980s initiated the legitimization of the neoliberal discourse in Portugal and marked a turning point in the consolidation of its welfare state. Not surprisingly, the retrenchment started even before its own "maturation." The Portuguese government, composed of a coalition of centre-right and right-wing parties, used the international welfare state crisis as an excuse to impose the retrenchment of universal social citizenship rights adopted since the 1976 Constitution, i.e., the revocation of the universal minimum scheme enacted by the Decree-Law n. 160/80 of May 28; and attempt to do away with the National Health Care System (SNS) in 1982, which was thwarted by the TC for violating the 1976 Constitution (Ferreira, 2005, p. 334). 
In 1982, the Constitution of 1976 was amended for the first time (TC, 1982). According to Rodrigues and Silva (2016), the main objectives were to demilitarize the Constitution and to reinforce its democratic principles. The ideological references to socialism in Article 2 were replaced by a broader, non-ideological reference to the fulfillment of economic, social and cultural rights (TC, 1982). Articles 63 and 64 that define and protect the rights to social protection and health care were also slightly amended to incorporate the role and contribution of civil society, as well as the decentralization of services (TC, 1982). According to Ferreira (2005), this Constitutional revision initiated the erosion of the universal social citizenship rights introduced earlier and paved the way for the approval of the new Social Security Act in 1984.

Despite its late transition towards democracy, Portugal was soon engulfed by the international wave of capital liberalization of the early 1980s that backed "privatized Keynesianism" and promoted the increase of private debt (Ferreira, 2005; Streeck, 2014). In September 1983, Portugal made a second request for financial assistance to the IMF as a result of a high deficit, a deep economic recession, high interest rates and trade imbalances. The financial assistance was for a total of 445 million SRD (Special Drawing Rights - an IMF currency code) at current exchange rates (about $€ 555$ million or US\$793 million) (IMF, 2017). The weakness of the Portuguese economy and the rise of public debt due to the gap between public revenues (taxes) and public expenditure opened the doors to unbridled, more laissez-faire capitalism and to a market-oriented approach towards economy and public budgets (Crouch, 2011; Ferreira, 2005; Streeck, 2014).

These elements represent common patterns and challenges to western industrialized economies. In the 1980s, southern European countries like Portugal faced a contradictory 
relationship between market capitalism and democracy that pushed them to developmental challenges of both an external and internal nature (Ferreira, 2005; Ferrera, 1996).

In 1984, a coalition government composed of socialists (PS) and social-democrats (PSD) approved the new Social Security Act (Law 28/84 of August 14). The main objectives of the new social security system were to protect workers and their families from social contingencies, i.e., unemployment, retirement, sickness, disability and death. It also provided other compensations, such as family allowances and social assistance (Diário da República Eletrónico [DRE], 1984; Instituto de Segurança Social [ISS], 2015). According to Ferreira (2005), this new Social Security Act adopted a residual role for social assistance by introducing new eligibility criteria and the conditionality of social protection based on means-testing of benefits (Monteiro, 1998). It was a return to the Bismarckian model of social protection where social citizenship rights were tied to the labour market and insurance premiums (Branco, 2003; Ferreira, 2005; Varela. 2016; Varela \& Pereira, 2015). According to Guillén et al. (2003, p. 231), Portugal's social protection system "showed most of the characteristics of an underdeveloped Bismarckian welfare state, segmented by occupational categories and suffering from broad gaps in the protection net." Therefore, the process of European integration had a substantial impact on the rights of social citizenship. The endeavour to consolidate democracy and join the European Economic Community (EEC) led to a redesign of the Portuguese Welfare State in the context of economic and financial constraint (Guillén et al., 2003). 


\section{The entry into the European Economic Community (EEC) in 1986}

The process of European integration represented the driving force for the development and transformations which have occurred in the Portuguese welfare state over the last few decades. It represented an opportunity for political stability and higher economic and financial capacity which directly influenced the increase in social spending (Branco, 2017; Guillén et al., 2003).

On January 1, 1986, Portugal joined the European Economic Community (EEC), now the EU, after withdrawing itself from the European Free Trade Association (EFTA), of which it was a founding member in 1960. A decade after Portugal's triple transition to democracy, economic development and a modern public welfare state, the entry into the EEC represented a relief and a step forward to a market-based economy (Branco, 2017; Monteiro, Tavares, Galtzer, \& Cardoso, 2003; Royo, 2004). Monteiro, Tavares, Galtzer, and Cardoso (2003, p. 3) argue that "the accession to the European Union [European Economic Community at the time] clarified Portugal's commitment to a market- based regime in the wake of the political and economic upheaval of the mid-1970s that involved high inflation and persistent fiscal imbalances." Certainly, from a marketoriented perspective, the process of European economic and monetary integration became even more important for Portugal.

Royo and Manuel (2003) also explained that Portugal has benefitted extensively from the European Social Fund (ESF) before and after joining the EEC (now EU). Such "structural funds" were used to improve bridges, roads and capital stocks which gave the opportunity to substantially reduce the inflation and interest rates that were experienced in the early 1980s and led to the IMF intervention (Royo \& Manuel, 2003). 
It is important to point out that the process of European integration for Portugal started in the 1960s with Salazar's Portuguese authoritarian regime, but those negotiations were blocked because of the lack of democracy (Magone, 2004). However, after the end of the revolutionary process (PREC) on the 25th of November 1975, the relations with the European Community were re-established and the negotiation process was reinitiated in the autumn of 1978 (Magone, 2004). According to Cabral and Soromenho-Marques (2014, p. 1), "Portugal formally applied to join the EU [European Economic Community, currently European Union] on March 28, 1977. It signed the pre-adhesion treaty on December 3, 1980." European integration was viewed as a way to consolidate democracy, as well as political, economic and social stability in Portugal (Royo, 2004). Between 1978 and 1985, Portugal undertook reforms at the institutional, social and cultural levels (Royo, 2004). At the same time, as Magone (2004) explains, Portugal faced political and economic instability, which postponed the final stages of negotiations to enter the EEC. Thus, the entry into the EEC aimed to consolidate the democratic process and promote European integration (Royo, 2004).

According to Baer and Leite (2003, p. 740), "at the beginning of 1986, when Portugal joined the European Union [EEC at the time], its GDP per capita was about $53 \%$ of the EU average; by 2002 it was about 75\% of the EU average." Between 1986 and 1990 the average GDP growth rate increased sharply to $5.4 \%$ when compared with the $0.9 \%$ average increase between 1981 and 1985 (Baer \& Leite, 2003, p. 740). Arguably, the EEC membership brought financial support and direct foreign investment that led to employment and economic growth. Better economic conditions, employment growth and infrastructure development contributed strongly to building support for European integration. Royo explains that support for European membership grew after 1980 (increasing from $24.4 \%$ in 1980 to over $90 \%$ in the 1990s) (Royo, 2004, p. 104). 
However, European integration also brought a forcible economic adjustment, the loss of sovereignty over economic and fiscal policies and a certain degree of cultural homogenization (Royo \& Manuel, 2003). As Royo and Manuel (2003, p. 4) explain, Portugal adopted several changes to adjust its legislation at the industrial, agricultural, economic and financial levels in order to align with the rules of the EEC. Such changes were adopted progressively through different stages and included, for example, changes in taxes, the introduction of a value added tax (VAT) and the removal of technical barriers to trade. Arguably, since Portugal joined the EEC, it not only accelerated its economic development and trade, but also embarked on fiscal and economic policies towards the EMU (the launch of the single currency project), which were a priority in the group of early euro adopters (Cabral \& Soromenho-Marques, 2014).

In terms of Portugal's welfare state and social expenditure, European integration contributed decisively to the consolidation of the modern and universal welfare state implemented after the 1974 revolution. According to Royo and Manuel (2003, p. 16), social expenditures increased substantially with Europe's support. New social policies and infrastructures were built and consolidated with European funds. Without such funding, Portugal could not have been able to consolidate and expand its welfare state in time for the newly created Washington Consensus which set a new role for the welfare state. At the time, and despite the late development of its modern welfare state, Portugal was facing almost the same challenges as other European industrialized societies - the aging of the population, a demographic backlash, changing family structure, and the transformation of the labour processes (Monteiro et al., 2003).

Portugal's labour market and social protection system follows a very specific welfare tradition, with peculiar characteristics. In the 1980s, Portugal's social protection was heavily dependent on funding from the public tax system (Guillén et al., 2003). However, at the 
international level, the approach towards the welfare state in the 1980s in Western industrialized economies was already being influenced by neoliberal ideas that influenced the so-called Washington Consensus - a standardized policy prescription for economic development (Blyth, 2013; Williamson, 2004).

The Washington Consensus needs to be understood and contextualized within the crisis of the welfare state that began in Western capitalist countries in the late 1970s (Gough, 1979; Navarro, 1982). This crisis marked the fall of the political and socio-economic order of the postwar called "Keynesianism" (Streeck, 2014). The rise of neoliberalism brought on the deregulation and liberalization of capital markets that led to globalization and a shift in fiscal and economic policies. It also initiated the transformation of the role of state towards support for a more open-market economy, globalization, and macroeconomic discipline, moving away from a "tax-state" to a “debt-state" (Blyth, 2013; Schafer \& Streeck, 2013; Streeck, 2014). Thus, liberalization and globalization were at the forefront among the standard policy priorities of the Washington Consensus (Blyth, 2013).

According to Williamson (2008, p. 14), "the term Washington Consensus was coined in 1989" by himself to define a set of policy prescriptions for Latin America that aligned with Reagan's and Thatcher's ideas of monetarism, supply-side economics, and minimal government (Williamson, 2008). The author's initial meaning was "a list of policies that Washington was seeking to impose on the world" (Williamson, 2004, p. 1). Such prescriptions and reforms comprised ten main measures: (1) Fiscal discipline; (2) Re-ordering of public expenditure; (3) Tax reform; (4) Liberalization of interest rates; (5) Competitive exchange rates; (6) Trade liberalization; (7) Liberalization of inward foreign investment; (8) Privatization; (9) Deregulation; and (10) Property rights (Williamson, 2008). The focus of this new economic and fiscal approach 
was on stability and growth. It shaped the new policy prescriptions of international financial institutions, like the World Bank and the IMF, and the views of the major industrialized economies of OECD countries, such as the US and the UK. However, as Williamson (2004, p. 2) acknowledges, such international financial institutions have been called agents of neoliberalism by their critics, since they attempted to impose the precepts of this revival of $19^{\text {th }}$ century liberalism through the shrinking the role of the state at economic and social levels.

However, we need to look at how the Washington Consensus connects to the European project and the EMU. The new world order put forward in the early 1980s by Reagan in the US and Thatcher in the UK led to the ideas and reforms proposed by the Washington Consensus, which were aligned with the project of the EEC towards the EMU (Crouch, 2011). It was in this international financial and economic reformist context that, in 1986, Portugal initiated its debut within the EEC. Despite the international backlash against a universal welfare state, Portugal's European integration brought stability and a new set of policies and funding to fight poverty and social exclusion. Undoubtedly, the first years within the EEC (EU), contributed decisively to the consolidation of social citizenship rights introduced previously.

By the late 1980s, Portugal's welfare state was characterized by a "corporatist" income maintenance system where the schemes and degree of social protection differed for public servants, private employees and the self-employed (Ferreira, 2005). Occupational status was a key factor in determining the type and degree of income maintenance (Ferrera, 1996). According to Ferrera (1996, p. 19), Portugal was characterized by "the lowest degree of fragmentation" among the Mediterranean countries - Spain (who entered in the EEC in 1986), Greece and Italy; while the national health care system, embodied in the Portuguese Constitution as a citizenship right, was almost universal (Ferrera, 1996). Cash benefits like old-age pensions and unemployment 
insurance rose significantly in terms of their benefits while the universal National Health Care System (SNS) remained as it was before 1986. The mandatory education system also increased from six to nine years in this period (Barreto, 1995; Ferrera, 1996) Such characteristics and gaps in social protection became more visible after European integration. (Ferreira, 2005; Ferrera, 1996). Why? Because such differences and gaps in Portugal's social protection system started being compared in the late 1980s with the so-called European social model, which exposed and pushed Portugal to introduce changes and reforms in the early 1990s. Furthermore, the international structural crisis of the welfare state and the process towards European economic and monetary integration, introduced and strengthened by the Treaty of Maastricht, have validated the retrenchment and reconfiguration of the welfare state (Ferrera, 1996). Such reformist tendencies initiated in the 1980s at the international level represented the "maturation" of the welfare state and the beginning of demographic changes in most OECD countries (Schafer \& Streeck, 2013). The decline of state capacity was due to the gap between public revenues (taxes) and public expenditure that "forced governments to set aside a growing share of their budgets to pay interest(s) to their creditors" (Streeck \& Mertens, 2013). As I mentioned in previous chapters, this represented a second wave of capital market liberalization (Crouch, 2011; Streeck, 2014).

One can say that the Single European Act (SEA), signed on the 28th of February 1986 represented the beginning of the process towards market liberalization within the EEC (EU) (EurLex, 2010a). The SEA enacted neoliberal ideas, reinforced the role of free markets and paved the way to new European institutions like the European Commission, the European Central Bank (ECB), among others (Eur-Lex, 2010a; Ferrera, 2013; Whyman, Mullen, \& Baimbridge, 2012a, 2012b). According to Whyman, Mullen, and Baimbridge (2012b, p. 64), the SEA was the outcome and operationalization of the "European Commission White Paper, entitled 'Completing the 
Internal Market', which contained a detailed programme and a timetable for the creation of a single European market by 1992.”

The SEA introduced substantial changes to the Treaty of Rome, signed on the 25th of March 1957, which came into force on January 1, 1958 (Eur-Lex, 2010a; European Parliament, 2018a). The Act marked a turning point towards integration by creating the conditions to establish a common single market. It extended the Union's power on monetary and social policy, economic and social cohesion, research and technological development, environment, and cooperation on foreign policy (Eur-Lex, 2010a; European Parliament, 2018a). The Act created the European Council to represent and bring together the heads of state or government of each European member state in order to define the political directions and priorities of the Union (Eur-Lex, 2010a; Whyman et al., 2012b).

Therefore, the SEA marked the turning point of the European project towards neoliberalism, a decisive contribution for completing the creation of the European Single Market (Whyman et al., 2012b). The approval and ratification of the SEA by all European member states determined the voluntary surrender to the Single Market (SM) project, with consequences for the control of macroeconomic policies (Schafer \& Streeck, 2013; Streeck, 2014; Whyman et al., 2012b).

This move had been idealized and proposed by Jacques Delors, a social-democratic French federalist appointed president of the European Commission (EC) in 1985 (Whyman et al., 2012b). Jacques Delors pushed the EEC from a market-building to a state-building dimension, as Whyman et al. put it (2012b, p. 64). What resulted was the creation of a common European social space through the harmonization of several standards and procedures at fiscal, economic and social 
levels. This illustrates the neoliberal turn and the push for an institutionalized form of unregulated financial and economic practices (Schafer \& Streeck, 2013; Streeck, 2014; Whyman et al., 2012b).

Although economic and financial liberalization were important and represented significant steps achieved by the SEA, another important transformation took place - the introduction of a European social dimension within the Union (Eur-Lex, 2010a, 2011a; Whyman et al., 2012b). The adoption of a European framework for social policy took place on December 9, 1989 with the enactment of the 1989 Social Charter, called the "Community Charter of the Fundamental Social Rights of Workers." The 1989 Social Charter defined the main principles on which European labour law is based (Eur-Lex, 2011a; Eurofound, 2011). It included fifty measures promoting "living and working conditions, health and safety at work, social protection, education and training" (L'Association Européenne pour la défense des Droits de l'Homme [AEDH], 2009, p. 1). Twenty of those measures had binding effect, in order to meet the Maastricht criteria imposed to enter into the EMU (AEDH, 2009, 2017; Eur-Lex, 2010; Eurofound, 2011). Clearly, the 1989 Social Charter assumed a key role within the process of economic liberalization introduced by the SEA. It aimed to stabilize the impact of the SM project and to contribute to the reduction of regional asymmetries within the Union. For Threlfall (2007), pushing social policies to the international level allowed for a strengthening of the globalization strategies directed to the EMU (Yeates as cited in Threlfall, 2007, p. 272). Therefore, the 1989 Social Charter defined the fundamental social rights of workers within the EEC/EU by transferring such decision-making to the international level (Threlfall, 2007).

This new method of coordination has been defined as the European Social Model (ESM). According to Jepsen and Serrano Pascual (2005, p, 232), the ESM can be defined as a "political project" that aims to promote economic growth and social cohesion. As mentioned before, Jacques 
Delors introduced the idea of the ESM in the mid-1980s. He proposed a plan where economic growth was tied with social cohesion (Jepsen \& Serrano Pascual, 2005). For Whyman et al. (2012a, p. 4), the ESM can be defined as a "multi-faceted approach encompassing elements of economic, social and labour market policy."

This created a mutual surveillance process between member states and the European institutions (Threlfall, 2007). By having a common European social dimension, the Union introduced a new model of production and social protection based on ideas of "flexisecurity", activation and coordination, defined and regulated by international institutions (Jepsen \& Serrano Pascual, 2005).

These new competencies on European decision-making enacted by the SEA directly influenced Portugal's integration and immersion within the ESM. The new method of coordination brought a new paradigm for Portugal's economic and social policies and directly influenced the widespread privatization of state-owned enterprises to reduce fiscal deficits and the supposed inefficiency of public administration (Braga de Macedo, 2003).

The years 1989-1992 marked a transition period towards the EMU with strong implications for economic restructuring and financial discipline that were aiming both for a financial and economic readjustment, both expenditure and revenue, to reduce deficits, increase competition, and boost free trade and capital mobility (Braga de Macedo, 2003). Such convergence plans and reforms aimed to push Portugal towards the so-called European average. 


\section{The reform of the social security system (1996)}

In 1995, Portugal turned towards the Left after 10 years of a social-democratic (PSD) rightwing government. On October 1, 1995, the Socialist Party (PS) won the legislative elections pushing the country into significant changes with regards to social protection since Portugal had joined the EU in 1986. Guillén el al. (2003, p. 259) note that the new Socialist government introduced a new framework for social protection, combining social protection against classic social risks (pensions and unemployment insurance) with new "activation" policies and measures that have redesigned the comprehensive social protection system. During the campaign the Socialist Party proposed the introduction of a Minimum Income scheme following the 1992 European Commission's recommendations (Branco. 2001; Branco, 2017; European Social Policy Network [ESPN], 2016; Eur-Lex, 1992; Ferreira, 2005). Therefore, following the trend of activation policies in the EU, Portugal initiated the introduction of a comprehensive package of reforms in its social protection system (Ferreira, 2005) in 1996. Those reforms included a wide range of measures in all components of its social protection system (Guillén et al., 2003). After coming into power, the socialist government also appointed, in 1996, the "White Book Commission of Social Security", a commission of experts to study the reform of the social security system, in particular the pension system (Arcanjo, 2011; Ferreira, 2005).

The major trending concerns with regards to social citizenship rights in 1996 among the 15 EU member states were about old age, health care, unemployment and family social policies (Arcanjo, 2011). However, the common criteria introduced by the Treaty of Maastricht in 1992 precipitated a profound transformation towards a new approach to social policies - the so-called activation policies. Thus, the 1992 European Commission's recommendations on GMI schemes directly influenced the convergence of social protection systems across EU by urging the adoption 
of non-contribution-based schemes providing a universal, non-insurance based scheme of income maintenance (European Economic and Social Committee [EESC], 2015; European Social Policy Network [ESPN], 2016).

In Chapter II, it was mentioned that Briggs (1961) defined the programs of minimum income as one of the core social citizenship rights. He explained that minimum income programs (GMI), also known as social assistance, provide a minimum threshold income irrespective of the market forces, work or prosperity. GMI programs are aimed at meeting the cost of the most basic human needs - the material living conditions - according to the minimum standards of living in each capitalist society, as Marshall suggested (Marshall, 1950, 1970).

The GMI programs were first recommended in Europe by the European Economic and Social Committee (EESC) in 1989 (EESC, 2015; ESPN, 2016). The EESC recommended in 1989 the introduction "of a minimum social income, both to act as a safety net for the poor and to boost their reintegration into society" (ESPN, 2016). In 1992, the recommendations made by the European Commission warned about the needs of the most vulnerable by encouraging the need for solidarity with the least privileged (Eur-Lex, 1992). Such recommendations recognized that everyone has the right to live with sufficient resources in order to sustain and respect the principles of human dignity (Eur-Lex, 1992). Changes in the economy, state/market relationships, and in the EU project created the opportunity to address social protection at the EU level. Thus, the introduction of a minimum safety-net across the EU was made through GMI programs. In the early 1990s, the majority of the EU member states had already adopted minimum income schemes. The only member states without a minimum safety net in the early 1990s were Greece, Portugal, Italy and Spain (EESC, 2015). 
The GMI program (known in Portugal as the Rendimento Mínimo Garantido or simply RMG) was the most comprehensive measure introduced by the new Socialist government in 1996. The Law n. 19-A/96 of June 29 established the RMG (GMI) (DRE, 1996). The RMG aimed to meet the material needs and generate "social activation" on several other dimensions - education, health care, labour market (employment and vocational training), social housing and access to social services (Branco, 2001). It not only provided an income support, but it also included a contracted intervention plan between the people and the different stakeholders (public, private and NGOs) covering different areas of intervention, according the needs of those getting income support (Batista \& Cabrita, 2009; Branco, 2001). The RMG was fully implemented in 1997 following the good results achieved by the 1996 RMG pilot-project. The regulatory Law n. 196/97 of July 31 defined the definitions, formulas, the conditions of eligibility to apply and benefit from the program, the procedures to be adopted in the "insertion program" and the articulation and participation of the different stakeholders (public, private and NGOs) (Branco, 2001; DRE, 1997).

According to Batista and Cabrita (2009, p. 5), the RMG principles were aiming to promote the rights of citizenship, as defined by T.H. Marshall (1950) - the right to a minimum income, the right to work, the right to education and the right to fully participate in society. The RMG aimed to tackle class inequalities and mitigate poverty by ensuring that all citizens were able to meet their material needs (Batista \& Cabrita, 2009; Branco, 2001; Briggs, 1961; Marshall, 1950).

Despite the shrinking of public welfare spending initiated in the early 1990s with the Treaty of Maastricht, the new GMI policy program introduced by Portugal (the RMG) sought to overcome the gap in social protection by increasing substantially the welfare state transfer effort from 9.3 percent in 1990 to closer to the average of the Beveridge group composed of Germany and Italy 
in the same period (Arcanjo, 2011). Arcanjo (2011, p. 147) characterized Portugal as a special case in the 1990s since the country registered the highest ratio of welfare state transfer effort.

As Branco (2001) describes, the introduction of the RMG in 1996 constituted the second biggest cornerstone since the implementation of social citizenship rights in Portugal by redesigning and revamping the foundation of welfare provision and, to some extent, reasserting the original aims of the protection system envisaged in the Constitution of 1976 (TC, 1976).

Despite the EU trend for constraints on public spending in the mid-1990s, the Socialist-led government also adopted measures to increase family allowances and old-age pensions by extending eligibility, providing new benefits and by increasing the rates for those receiving pensions at the lower end of the scale. (Ferreira, 2005). However, curbing public expenditure was also a key concern (Arcanjo, 2011). Before releasing its final report, the "White Book Commission" proposed several preliminary recommendations regarding the implications of lower old-age pensions, the age of retirement, and pension rates among others (Arcanjo, 2011; Guillén et al., 2003).

\section{Conclusion}

As welfare states have changed in all OECD countries since the 1980s, Portugal has faced several challenges and pressures from the very beginning of the creation of its democratic public welfare state in 1976 to 1996 when it finally introduced a minimum income cash benefit program.

This chapter sought to explore the historical development of social citizenship rights in Portugal while discussing the economic, political and social factors that contextualized and characterized the dynamics that have either influenced or limited the development and maturation 
of the Portuguese welfare state since the 1974 Carnation revolution to the period after joining the EEC in 1986.

This chapter also demonstrated how Portugal benefited from the European integration both with respect to its economy and the welfare state. It worked as a carrot and stick approach since it not only accelerated Portugal's economic development but it enmeshed the country in the EMU's fiscal and economic policies, policies which are explored in the following chapter. Arguably, the process of European integration considerably influenced the development and consolidation of the Portuguese welfare state between 1976 and the early 1990s. However, as this chapter showed, once in the EEC/EU, Portugal embarked on a profound process of transformation of its welfare state towards a new approach to social policies - the so-called activation policies (Ferreira, 2005).

Thus, the next chapter introduces the European budgetary rules that were introduced since the Treaty of Maastricht in 1992. Such fiscal rules constitutionalized sound fiscal policies and budgetary discipline to all EU member states, like Portugal, who joined the EMU to share Euro as a single currency. 


\section{Chapter IV: Europe's budgetary rules}

\section{Introduction}

In Portugal, certain events which have occurred over the last decades - in particular, joining the EU and the adoption of its single currency, the Euro - have drastically influenced the relationship between citizens and the state. Since the signature of the Treaty of Maastricht in 1992, Portugal has encountered several constraints that have directly influenced social expenditure and the way social protection is provided. Public expenditure has become tied to the objective facts of the market economy and the budgetary discipline imposed by the EU to all member states who adopted the Euro as a common currency. Such tighter fiscal rules may be especially problematic for countries like Portugal with specific political, economic, social and cultural differences, as well as smaller, less strong economies in comparison to other EU members like France and Germany.

The establishment of the European single market and the adoption of non-Keynesian economic policies represented the beginning of a "new" policy paradigm within the EU that drew on Friedman's monetarist theories (Blyth, 2013; Friedman, 1962; Palier, 2013; Piketty, 2014). Palier (2013, p. 39) explains that, such "monetarist, neoclassical supply-side policies were intended to promote business competitiveness and they were characterized by wage moderation, budgetary rigor and by general deregulation and flexibility."

For such reasons, this chapter puts particular emphasis on an analysis of the Treaty of Maastricht and on the rules introduced by the Stability and Growth Pact (SGP). This analysis will assist in a better understanding of the process of welfare retrenchment in Portugal following the 2008 financial crisis and the austerity policies that ensued. 


\section{The Maastricht treaty (1992)}

In the early 1990s, the EU initiated a new stage of economic, fiscal, political and social development. The signing of the Maastricht Treaty on February 28, 1992, officially known as the Treaty on European Union (TEU), came into force on November 1, 1993, after being ratified by all the twelve EU member states. It made real the intent to constitutionalize the victory of neoliberalism through a set of binding expansionary and budgetary policies to promote economic growth and fiscal discipline, while shrinking public social spending (Eur-Lex, 1992a, 1992b; European Parliament, 2018b; Evans, 2014; Laursen, 2012; McBride, 2014; Palier, 2013). The Treaty signalled the end of the European Economic Community (EEC) and the arrival of the European Union (EU) (Eur-Lex, 1992a, 1992b).

The Maastricht Treaty (or TEU) laid the foundations of the EU by creating or consolidating a set of European institutions - the European Parliament, the Council, the Commission, the Court of Justice, the Court of Auditors and the ECB (Eur-Lex, 1992a, 1992b; European Parliament, 2018b; Laursen, 2012). It also provided the road map to create a common currency by establishing the EMU through three stages (Baerg \& Hallerberg, 2016). The first stage liberalized the free movement of capital and people by establishing a common market without internal borders. The second stage (in 1994) introduced several monetary rules, commonly referred to as "Maastricht criteria" or "convergence criteria" to be adopted by EU member states for transitioning and adopting the Euro as a single currency. The third and final stage (1999) introduced the singlecurrency Euro (Baerg \& Hallerberg, 2016; Eur-Lex, 1992a, 1992b). The four "convergence criteria" (initially in Article 109 of the Treaty of Maastricht, which later became Article 121 of the TEU, version of 2002) were preconditions to be met to join the Euro - control over inflation; amount of public debt and public deficit; convergence interest rates; and exchange rate stability 
(Blyth, 2013; Eur-Lex, 1992a, 1992b; European Parliament, 2018b; Laursen, 2012). One of the most important criteria that forced member states to commit to budgetary discipline was adhering to the maximum of $-3 \%$ of public deficit as a percentage of GDP and a maximum of $60 \%$ of public debt (as percentage of GDP) (Blyth, 2013; Eur-Lex, 1992a, 1992b; Hemerijck, 2002; Laursen, 2012). For Scharpf (2013, p. 108), the EMU "has removed crucial instruments of macro-economic management from the control of democratically accountable governments." The Maastricht Treaty also led to the creation of the notion of European citizenship and strengthened the cooperation between member states on mobility, foreign and security policy (Eur-Lex, 1992a, 1992b).

Although the Maastricht Treaty stressed budgetary discipline, it also directly influenced the European convergence of employment and social policies (Hemerijck, 2002; Palier, 2013). The objectives of the protocol on social policy (article 1) were the promotion of employment, improvement of living and working conditions, adequate social protection, social dialogue, the development of human capital, and the fight against social exclusion (Eur-Lex, 1992b; Hemerijck, 2002). Hemerijck (2002, p. 19) explains that "the principal site for welfare reform remains the nation-state, but the center of decision-making was substantially affected by the EMU as a result of "supranational regulation and policy initiatives." Thus, the EU represents a system of multilevel governance. The Treaty of Maastricht introduced a system of economic and fiscal governance that coordinates and links national and international levels. According to Sapir (2006, p. 382), "in the microeconomic sphere, labour market regulation is decided at national level, whereas the EU level deals with product and capital market regulation. In the macroeconomic sphere, the member states are responsible for fiscal policy, but monetary policy is managed by the ECB for countries belonging to the euro area [initiated in 1999]." Thus, Sapir's description shows that economic policy is the motto of EU. The EMU was the culmination of a policy framework initiated in the 
1980s centered on economy stability and public debt reduction. Thus, the EMU played a critical role by shifting the focus from labour market exit to employment maximization. As a result of these changes between the 1990s and the 2000s, the EU member states shifted their priorities to active labour market policies (Hemerijck, 2011).

The influence of the Treaty of Maastricht on the welfare state reforms initiated in the 1990s by the EU member states played a key role in the evolutionary process of welfare retrenchment. Burkitt and Baimbridge (1994, p. 101) argued that "the Maastricht Treaty threatens the welfare state further by requiring the attainment of fiscal convergence as a precondition for economic monetary union (EMU)." Therefore, in the 1990s, EU member states initiated a new phase of welfare retrenchment in Europe by cutting welfare benefits to meet the Maastricht convergence criteria (Burkitt \& Baimbridge, 1994). This marked a new trend on the attack on public welfare provision, the price to be paid for developing a common market and adopting a single-currency.

Curiously, this European shift on the expenditure of public welfare provision occurred when Portugal was still consolidating its public social protection system. In the early 1990s, Portugal raised old-age pensions and other cash benefits like unemployment insurance. It also extended the mandatory school system, from six to nine years (Barreto, 1995). Although eligibility was universal, rates of cash benefits were not robust enough to get by. The late development of Portugal's welfare state explains why, in the early 1990s, the degree of social protection in Portugal was still very fragmented with different schemes for public, private and self-employed workers. This is one of the characteristics of social protection in southern European countries like Portugal: cash benefits are based on occupational status (Ferrera, 1996). Such duality in income maintenance benefits explains one of the two hypotheses highlighted by Navarro, Schmitt and Astudillo (2004) about the impact of globalization of economic activities on the ability to maintain public welfare 
states. They argue that the first hypothesis ("politics still matter") points to the influence of political forces in sustaining the level of public welfare expenditure, which to some extent contradicts the idea that globalization and the politics of consolidation introduced by the Treaty of Maastricht had an immediate effect on the retrenchment of the welfare state (Burkitt \& Baimbridge, 1994; Navarro, Schmitt \& Astudillo, 2004). Certainly, the late development of Portugal's welfare state justifies the need to consolidate and expand the public provision of social citizenship programs and services. The other hypothesis highlighted by Navarro, Schmitt and Astudillo (2004) is the "convergence" hypothesis which defends a reduced level of public welfare expenditure. The Treaty of Maastricht controlled the "convergence" and retrenchment of public welfare states by imposing a regime of fiscal austerity (Eur-Lex, 1992a, 1992b; Navarro, Schmitt, \& Astudillo, 2004). The fiscal consolidation has been explained by Streeck (2014).

The politics of the "consolidation state" began in the 1980s as a result of the transformation of the so-called "tax state" into the "debt state" (Streeck, 2014). One of the main characteristics of the "debt state" is fiscal consolidation as a result of covering public expenditure through borrowing from financial markets (Streeck, 2014). According to Streeck (2014, p. 97), the "consolidation state" can be defined "as an international regime operating at multiple levels of government." This defines and characterizes the EU. Streeck (2014) explains that, "the EU thus became a machine for liberalization of European capitalism, enabling (and sometimes compelling) governments to impose any manner of pro-market reforms against the resistance of the citizens." The Treaty of Maastricht institutionalized the liberalization of European capitalism by introducing new regulations, institutions and instruments with the purpose of consolidating the public finances of EU member states. Such regulations and instruments would later neutralize domestic politics in favour of international agreements and regulatory regimes (Palier, 2013; Streeck, 2014). Thus, the 
EU member states signed a Treaty which then tied their fiscal and economic policy into the EU as an international dimension, which then subjected the member states to the regulations of the EU rather than to their own national states. The member states emasculated themselves through the Treaty (Streeck, 2014).

\section{The stability and growth pact}

The signing of the Treaty of Maastricht in 1992 established the EMU and defined several monetary rules, known as the as "Maastricht criteria" (or "convergence criteria") to be adopted by EU member states for transitioning and adopting the Euro as a single currency (Blyth, 2013; EurLex, 1992a, 1992b; European Parliament, 2018b). As I mentioned before, the Treaty defined four "convergence criteria" to be met - control over inflation; levels of public debt and public deficit; convergence interest rates; and exchange rate stability (Blyth, 2013; Eur-Lex, 1992a, 1992b; European Parliament, 2018b).

The Treaty of Maastricht was amended by the Treaty of Amsterdam, which was signed on October 2, 1997 and entered into force on May 1, 1999 (European Parliament, 2018b; Eur-Lex, 1997a). According to Vanhoonacker (2012, p. 135), the Treaty of Amsterdam was more "than merely an extension of Maastricht as the deliberations took place against a changed background." Several explanations can be given about why this new Treaty was introduced. Bringing Europe closer to its citizens, preparing the groundwork for future expansion of the EU, improving the effectiveness of foreign policy making and security policy, and strengthening fundamental citizen rights, employment and social policies. For the purpose of this study, however, the most important aims and developments were the resolutions adopted during the preparatory proceedings to the 
Treaty of Amsterdam at the meeting of the European Council in Amsterdam in June 16-17, 1997, aiming to promote and reinforce the financial stability initially introduced by the Treaty of Maastricht (European Parliament, 2018b; Eur-Lex, 1997a, 1997b; Vanhoonacker, 2012).

Therefore, the preparatory proceedings to the Treaty of Amsterdam set the political basis for the SGP. The SGP, was born in June 17, 1997, with the approval of a resolution at the European Council meeting in Amsterdam (Eur-Lex, 1997b). This European Council resolution detailed the commitments of the EU member states to the EMU (Eur-Lex, 1997b). The implementation of the SGP reinforced the criteria introduced by the Treaty of Maastricht by constitutionalizing the commitment to sound fiscal policies and budgetary discipline (Eur-Lex, 1997b). The SGP represents the consolidation of the second stage of the EMU and a step forward towards the introduction of a single currency in 1999; this represented the third and final stage of the EMU (Eur-Lex, 1992a, 1992b).

The SGP was formally adopted in July 7, 1997 by Council Regulations No. 1466/97 (known as the preventive arm of the Stability and Growth Pact) and No. 1467/97 (known as the corrective arm of the Stability and Growth Pact) (Eur-Lex, 1997c, 1997d). These regulations have set out the SGP framework for effective multilateral surveillance and have defined the penalties for the "excessive deficit procedure." As described in Article 1 of Council Regulation No. 1466/97, "[t]his Regulation sets out the rules covering the content, the submission, the examination and the monitoring of stability programmes and convergence programmes as part of multilateral surveillance by the Council so as to prevent, at an early stage, the occurrence of excessive general government deficits and to promote the surveillance and coordination of economic policies" (EurLex, 1997c, p. 2-3). Further, Article 3, No. 1 mentions that "[e]ach participating Member State shall submit to the Council and Commission information necessary for the purpose of multilateral 
surveillance at regular intervals under Article 103 of the Treaty in the form of a stability programme, which provides an essential basis for price stability and for strong sustainable growth conducive to employment creation" (Eur-Lex, 1997c, p. 3). Article 3, No. 2 of Council Regulation No. 1466/97 also details the information that should be included in the SP to be submitted annually to the European Council after 1999. The annual Stability Programme must include for example "a description of budgetary and other economic policy measures being taken and/or proposed to achieve the objectives of the programme, and, in the case of the main budgetary measures, an assessment of their quantitative effects on the budget" (Eur-Lex, 1997c). Therefore, the preventive arm of the SGP (Council Regulation No. 1466/97), which entered into force in 1998, requires the definition of "Medium-Term Budgetary Objectives" (MTOs) which are defined in structural terms and updated every 3 years or more frequently, if a member state is facing significant structural reforms (Eur-Lex, 1997c).

Council Regulation No. 1467/97 (known as the corrective arm of the Stability and Growth Pact) defined the procedures and conditions to be applied under the "excessive deficit procedure." Article 1, No. 1 explains that "the objective of the excessive deficit procedure is to deter excessive government deficits and, if they occur, to further prompt their correction, where compliance with the budgetary discipline is examined on the basis of the government deficit and government debt criteria" (Eur-Lex, 1997d). Special attention should be drawn to the sanctions under Section 4 Articles 11 to 16, where punitive measures to member states are described. The corrective arm of the SGP entered into force in 1999 (Eur-Lex, 1997d).

As Scharpf (2013) explains, the SGP was designed to control public deficits, to increase the integration of capital and to achieve the convergence of prices, wages and business cycles. In the EU's view, the SGP was intended to address the economic and fiscal problems of creating an 
“optimum currency area." As member states are not homogeneous, neither wage nor price flexibility could easily be pursued by all member states in the Eurozone area. Thus, price stability and national public deficits were the main concern of the EU (Blyth, 2013; Scharpf, 2013). However, the SGP represented and continues to represent a serious threat to public spending on social citizenship rights. Such monetary policy promotes primarily budgetary discipline and has contributed decisively to the introduction of another layer of welfare retrenchment within EU. The Treaty of Maastricht has imposed permanent limits on public national deficits and indebtedness along with sanctioning procedures. EU member states, in particular those who joined the EMU, are obligated to comply with this monetary and fiscal framework. Thus, as I mentioned earlier in the Introduction of this dissertation, the SGP stipulates the deficit and debt ceilings of 3\% of GDP and $60 \%$ of GDP respectively (Eur-Lex, 1997b, 1997c, 1997d). It becomes clear that national needs and interests will be superseded by a set of economic and fiscal international rationalities and practices to be adopted under the policies and objectives of the EMU. The SGP aimed to coerce member states to low inflation, balanced budgets, stable exchange rates regardless of the impact on employment, minimize income redistribution and decommodification (conditionality) of social citizenship rights or even having the effect of rendering the ideology of a political party meaningless unless it can conform to the SGP. As Blyth (2013) argues, the SGP represents particular ideas of capitalism - the German ordoliberal tradition and the Anglo-American model. Furthermore, Blyth explains that the ordoliberal principles were incorporated into the EU project and its institutions - European Commission and ECB - and applied to the Maastricht convergence criteria of the EMU and the SGP. If rules are violated, the prescribed penalty is or will be austerity in addition to sanctions for those member states who violate the rules. Thus, the same economic and fiscal paradigm is replicated among all EU member states with the expectation that the results 
will be the same. However, at the time the SGP was introduced member states like Portugal, Spain and Greece were not at the same stage of economic development and growth as the other longerterm members like Germany, France and the UK.

The monetary stabilization of the world-economy that began in the early 1980 s under the Reagan and Thatcher governments led to the beginning of the public-debt era in the late 1980s (Merkel, 2014; Streeck, 2014). In order to maintain and stabilize democracy, political power and people's demands for more social protection, governments turned to debt as a way to finance their public spending, or what Crouch (2011) defined as "Privatized Keynesianism" (Streeck, 2014). Thus, the rise of public debt, the liberalization of the economy and the deregulation of the banking system in OECD countries, particularly in Europe, were consequences of globalization and of the politics of the "consolidation state" (Streeck, 2014). Therefore, the SGP represents the application of monetary policy to operationalize the existence of the EMU and to constitutionalize and strengthen the liberalization of European market capitalism (Blyth, 2013; Crouch, 2011; Streeck, 2014). This initial version of the SGP, known as the preventive and corrective arm of the SGP, marked the beginning to constitutionalize debt ceilings by all EMU member states.

In 2005, the SGP (composed by the Council Regulations No. 1466/97 and No. 1467/97) was amended by Council Regulations No. 1055/2005 and No. 1056/2005 of June 27, 2005 in order to better differentiate and accommodate the national circumstances of each member state within the EMU (EU Council, 2005; Eur-Lex, 2005a, 2005b). The Economic and Financial Affairs Council (ECOFIN) prepared a report to the EU Council where it presented proposals for strengthening and clarifying the SGP in its original version in order to improve the coordination and monitoring of economic and fiscal policies in five main areas: (1) economic rationale of the budgetary rules; (2) ownership of national policy making; (3) timing and effectiveness of 
budgetary consolidation; (4) implementation of Council recommendations; and (5) monitoring of debt and sustainability (EU Council, 2005, p. 4). Thus, the recommendations made to the EU Council aimed to improve the EU governance and its fiscal framework, strengthen the preventive arm and improve the implementation of the deficit procedure (EU Council, 2005). For example, in its conclusions, the ECOFIN report recommended that, the SP MTOs should also take into consideration the differences of each member state in terms of their economic diversity, policy priorities and stage of development (EU Council, 2005; Eur-Lex, 2005a). The report was adopted by the EU Council through the Council Regulation No. 1055/2005 on the strengthening of the surveillance of budgetary positions and the surveillance and coordination of economic policies (Eur-Lex, 2005). The other original SGP regulation being amended was the Council Regulation No. 1467/97 on speeding up and clarifying the implementation of the excessive deficit procedure (Eur-Lex, 1997d). The Council Regulation No. 1056/2005 aimed to simplify and clarify the application of the excessive deficit procedure by revising its wording, the criteria to be used for exceptions, the reference values for short and long terms, the guidelines for budgetary assessments and extension of the window period between the reporting and the sanctions (Eur-Lex, 1997d). Therefore, these amendments clarified the implementation and procedures to make the SGP more effective while taking into account the national circumstances of the different member states.

The Treaty of Lisbon signed on December 13, 2007 (came into force on 1 December, 2009) introduced several amendments to the Treaty of Maastricht (1993) and the Treaty of Rome (1958) (Eur-Lex, 2008a). These amendments, in particular those made to the Treaty of Maastricht by the Treaty on the Functioning of the European Union (TFEU) established the legal basis of the SGP under Articles 121 and 126 and by Protocol No. 12 of the Treaty (Eur-Lex, 2008b, 2008c, 2008d). The Treaty of Lisbon also introduced important measures to protect and ensure the realization of 
citizenship rights, in particular social citizenship rights through the Charter of Fundamental Rights of the EU initially proclaimed on December 7, 2000 and later amended in its wording in 2012 (Eur-Lex, 2012a). I will return to this Charter while analyzing and discussing the impact of austerity measures adopted in Portugal between 2011 and 2014 as a result of the SP and MoU.

In terms of economic and monetary policy, as I mentioned above, the TFEU has defined under Articles 121 and 126 (formerly Articles 99 and 104 of the TEC), the legal basis of the SGP on multilateral surveillance and excessive deficit procedure (Eur-Lex, 2008b, 2008c). The TFEU has also forced the compliance of member states with the EU neoliberal monetary project in Article 120 which states that "Member States shall conduct their economic policies with a view to contributing to the achievement of the objectives of the Union, as defined in Article 3 of the Treaty on European Union, and in the context of the broad guidelines referred to in Article 121(2). The Member States and the Union shall act in accordance with the principle of an open market economy with free competition, favouring an efficient allocation of resources, and in compliance with the principles set out in Article 119." (Eur-Lex, 2008a). When observing the principles set out by Article 119 - stable prices, sound public finances and monetary conditions and a sustainable balance of payments, it can be said that the EMU project has been erected based upon neoliberal ideas to enforce and constitutionalize the agency of capital in the EU project (Sandbeck \& Schneider, 2014). Thus, Articles 119 and 120 bind EU member states into the theories of monetarism by Milton Friedman (1962) and the resulting neoliberal austerity politics and policies that arise from adopting those theories (Blyth, 2013; Sandbeck \& Schneider, 2014). Later, I will explore and discuss, in more depth, how the drive towards the EMU and the SGP rules relate to Friedman's Monetarism (Blyth, 2013; Friedman,1962). 
Protocol 12, annexed to the Treaty, provides further details about the excessive deficit procedures referred to in Article 126 No. 2 of the TFEU. Article 1 of Protocol 12 defines the reference values: a maximum annual budget deficit of 3\% of GDP; and a maximum national debt of $60 \%$ of GDP (Eur-Lex, 2008d). Thomas Piketty (2014, p. 565) argues that "the precise economic logic behind these choices has never been completely explained." Further, he considers that such budgetary constraints are historically unprecedented (Piketty, 2014, p. 566).

In 2011, a new set of rules for economic and fiscal surveillance, known as the "Six-Pack", amended the SGP. The "Six-Pack" came into force on December 13, 2011 after being approved by 27 member states. The "Six-Pack" is composed of five regulations and one directive that aimed to reinforce the preventive and corrective arm of the SGP (Euro-Lex, 2011b, 2011c, 2011d, 2011e, 2011f, 2011g). It represented a comprehensive enhancement of fiscal and macroeconomic surveillance aiming to reinforce economic and fiscal stability within the EU. This amendment took place following the 2008 financial crisis and the 2010 EU sovereign debt crisis to ensure fiscal discipline and economic stability within the EU. The "Six-Pack represents the legal basis of a wider reform of policy coordination introduced in 2010 called "European Semester" (Eur-Lex, 2010c). The "Six-Pack" was therefore an early response to the financial and economic crisis for preventing and solving the fiscal and macroeconomic imbalances. It introduced new procedures to correct excessive deficits. For example, the new "macroeconomic imbalances procedure" defined expenditure benchmarks under the preventive arm of the SGP and enforced financial sanctions for Eurozone member states who violate their obligations under the excessive deficit procedure, among others (European Commission, 2011b). According to a European Commission press release, by the end of 2011, 23 out of 27 EU member states were under the excessive deficit procedure mechanism, meaning that their budget deficit was higher than $3 \%$ of GDP and their 
public debt was above $60 \%$ of GDP (European Commission, 2011b). Thus, the "Six-Pack" introduced new procedures to correct the excessive deficit of eurozone member states such as the new "macroeconomic imbalances procedure", which defined expenditure benchmarks under the preventive arm of the SGP, to enforce financial sanctions for Eurozone member states who violate their obligations under the excessive deficit procedure, among others (European Commission, 2011b).

In 2013, two major enhancements on budgetary policy and economic governance were added. On January 1, 2013, the new intergovernmental Treaty on Stability, Coordination and Governance in the Economic and Monetary Union (TSCG) entered into force after being ratified by twelve Eurozone member states. The TSCG was signed on March 2, 2012 by 25 member states with the exception of the UK and the Czech Republic (European Commission, 2012a, 2012b). The main provision of the Treaty is the "Fiscal Compact" (Part III, Articles 3 to 8), an agreement to strengthen the preventive arm of the SGP, by requiring the implementation of balanced budget rules in the national law of EU member states. Thus, along with the imposition of mandatory budget rules, the "Fiscal Compact" also introduced other measures - strengthening of the excessive deficit procedure, a benchmark for government debt reduction and the need for public debt issuance plans (European Commission, 2012a, 2012b).

Other important reforms on budgetary surveillance and economic governance entered into force in 2013. The "Two-Pack" reform consists of two regulations proposed by the European Commission to strengthen even further the SGP and the surveillance mechanisms in the Eurozone (Eur-Lex, 2013a, 2013b; European Commission, 2013). In November 2011, because of the shortcomings of previous legislation for the SGP the European Commission was forced to propose this reform package as a result of the impact of the 2010 sovereign debt crisis. According to the 
European Commission press release MEMO/13/457, the "Two-Pack" brought more of a shared responsibility and coordination along with risk sharing within the Eurozone (European Commission, 2013). The "Two-Pack" integrated some of the elements of the "Fiscal Compact" Treaty into EU law. Thus, the "Two-Pack" comprises Regulations No. 472/2013 and No. 473/2013 with new rules to the corrective arm and the excessive deficit procedure of the SGP aiming to further enhance economic integration and convergence within the Eurozone. This new framework focused on coordination and closer monitoring when compared with the changes introduced by the "Six-Pack". Thus, the "Two-Pack" regulations introduced a common budgetary timeline and common budgetary rules for member states within the Eurozone. For example, the forthcoming budgetary cycle introduced by the "Two-Pack" is: (1) by April 30, Eurozone member states must publish their medium-term fiscal plans (Stability Programmes), together with their policy priorities for growth and employment for the forthcoming 12 months (National Reform Programmes); (2) by October 15, Eurozone member states must publish their draft budgets for the following year; and (3) by December 31, Eurozone member states must adopt their budgets for the following year (European Commission, 2013). The "Two-Pack" gave more power to the European Commission by taking into account member states' opinion in each draft budget by November 30 of every year. It also gave the power to request a revised plan if the draft budget does not meet the SGP requirements (Eur-Lex, 2013a, 2013b; European Commission, 2013).

The monitoring and assessment of the member states draft budgetary plans by the European Council and the European Commission show that the EU's ordoliberal fiscal surveillance has succeeded, despite the outcomes of the 2008 financial crisis and the 2010 EU sovereign debt crisis. The numerous policy changes during the crisis and the adoption of new regulations and procedures aimed at reinforcing the fiscal surveillance and budgetary decisions clearly laid down the 
strengthening of surveillance mechanisms and the vulnerability to protect from the budgetary targets (the so-called austerity measures), the public spending on the welfare state.

In 2014, the "Six-Pack" and the "Two-Pack" were assessed by the European Commission to strengthen the effectiveness and applicability of the SGP (Eur-Lex, 2014). Although the "SixPack" has enhanced the rules and instruments for fiscal and economic surveillance of both SGP preventive and corrective arms, and was further improved by the budgetary coordination brought by the "Two-Pack" regulations, the European Commission has considered the need to evaluate the "Six-Pack" and "Two-Pack" regulations. On November 28, the European Commission adopted the communication "COM/2014/0905 final" in which it presented a condensed review of the "SixPack" and the "Two-Pack" regulations (Eur-Lex, 2014). The European Commission's communication questioned the effectiveness of the "Six-Pack" and the "Two-Pack" regulations introduced in 2011 and 2013 respectively. The aim of this communication was to assess the effectiveness and performance of both regulations on fiscal surveillance, on the macroeconomic imbalance procedure, on their contribution to achieve financial stability and on the revised economic governance coordination system. The European Commission proposed to the EU Council and the EU Parliament possible areas for improvement, particularly on the preventive and corrective arms of the SGP 2011 reforms and on the application of the macroeconomic imbalances' procedure per member state between 2012-2014 (Eur-Lex, 2014).

Finally, in 2015, the SGP had its last amendment that stands in force to the present day the flexibility of the SGP rules (Eur-Lex, 2015). The European Commission released the communication "COM (2015) 12 final" on January 13, 2015 in which it provided recommendations for structural reforms and investment under the previous "Six-Pack" and "TwoPack rules. It also analyzed how flexibility could be used under the existing SGP rules (Eur-Lex, 
2015). According to the European Commission's communication "the flexibility varies depending on whether a Member State is in the preventive or the corrective arm of the Pact" (Eur-Lex, 2015, p. 4). Arguably, these new guidelines offer new interpretations and more flexibility under the SGP rules. This position marked a stage and a policy approach in the aftermath of the 2010-2014 European debt crisis period, particularly in Southern European countries like Portugal and Greece. The impact and applicability of these SGP flexibility guidelines will not be taken into consideration since the period of analysis is the 2008-2014 period from the beginning of the 2008 financial crisis until the end of 2014, the period shortly after Portugal concluded its bailout program with the Troika on June 2014.

Given this context, the analysis of the SGP that has been provided has shown how the mechanisms of macro-economic and fiscal surveillance were developed and implemented since the Treaty of Maastricht came into force in 1993 (Eur-Lex, 1992a, 1992b; Sandbeck \& Schneider, 2014). The guidelines set under the Treaty and the arguments for the expansion of fiscal and monetary policies, under the justification for reaching and participating in the EMU with its common currency are closely associated with the neoliberal and ordoliberal principles of currency stability and budgetary discipline (Blyth, 2013; Sandbeck \& Schneider, 2014). For example, McBride (2016, p. 6) argues that, the SGP rules were designed to protect specific neoliberal policies that aimed to constitutionalize balanced budget rules. This "new" policy paradigm, in fact, draws from an old paradigm - Friedman's politics of monetarism (Blyth, 2013; Friedman, 1962; Piketty, 2014). This set of ideas put money front and center instead of citizens and reinforced ordoliberal austerity approaches by prioritizing markets over state policies. Thus, the SGP and its "Six-Pack", Fiscal Compact and "Two-Pack" rules uphold the monetarist paradigm to reinforce the EMU integration through its fiscal surveillance and consolidation framework (Baerg \& 
Hallerberg, 2016; Blyth, 2013; De La Porte \& Heins, 2015; McBride, 2016; Sandbeck \& Schneider, 2014). Moreover, the combination of the Treaty of Maastricht, the TFEU, the SGP rules and the TSCG ruled out currency devaluation and the use of budget deficits by national governments. Therefore, the SGP clearly embodies a high level of policy enforcement to achieve permanent fiscal consolidation within the EMU. It paved the way for the politics of austerity that were adopted (Baerg \& Hallerberg, 2016; Blyth, 2013; De La Porte \& Heins, 2015; McBride, 2016; Sandbeck \& Schneider, 2014; Scharpf, 2013). As I have shown, since the SGP was adopted, rules and procedures have gradually become tighter. The aim and commitment to strengthen and improve the EMU led to the adoption of several surveillance and corrective mechanisms that pressured national welfare states by reducing public expenditure on social citizenship rights, imposing labour market deregulation and influencing welfare state reforms.

How did the EMU and the SGP rules affect the welfare state in Portugal? In the Introduction of this dissertation I mentioned that I considered the analysis of welfare retrenchment through the paradigm of austerity of significant importance. As mentioned, the second research question that guides this dissertation relates to the impact of austerity measures on social citizenship rights caused by those measures adopted under the SP programs in Portugal between 2010 and 2011 and the MoU under the bailout program signed with the Troika between May 2011 and June 2014.

\section{Conclusion}

The 1990s marked an important stage in the development of the EMU within the EU. The Treaty of Maastricht was the cornerstone and a step forward to advance the European economy 
(Bieling, 2006). The new model of political and economic governance that began with the Treaty of Maastricht, later reinforced by the approval of the SGP in 1997, forced EU countries to comply with budgetary consolidation within the EMU (Palier, 2013; Peters, 2011). Moreover, the deregulation of the economy and of the financial system, and a new supra-national level of governance created the ideal conditions to limit the scope of government actions on the welfare state (Bieling, 2006; Peters, 2011). As Palier (2013) explained, “[i]n this new economic policy model, social protection expenditure and the state no longer had the same functions. Social protection schemes have had to be adapted to supply-side economic policies rather than demandside ones." Thus, this chapter has sought to discuss the key EU regulations that initiated the process of retrenchment of the welfare state in EU, which began prior to the 2008 financial crisis.

The next chapter focuses on Portugal as a case study. It analyzes the retrenchment of the welfare state under the paradigm of austerity through a detailed analysis of the impact of austerity measures on cash benefits of social citizenship rights between 2008 and 2014 . 


\section{Chapter V: The retrenchment of social citizenship rights in Portugal under the paradigm of austerity (2008-2014)}

\section{Introduction}

The 2008 financial crisis marked a new stage in the process of retrenchment of the welfare state of modern capitalist economies. While the European-wide austerity wave began in 2010, Portugal soon faced the effects of such a new type of financial crisis, a threefold one: a bank crisis, a crisis of public finances and a crisis of the real economy (Blyth, 2013; Streeck, 2014). Undoubtedly, this new paradigm shift offered the trigger to analyze the influence and impact of the politics of austerity in the process of retrenchment of the welfare state (Ferguson et al., 2018; Gilbert, 2013; Palier, 2013; Pierson, 2001).

This chapter details the different types of austerity measures adopted by the Portuguese government or imposed by the Troika under the SGP rules and the MoU with the Troika since the 2008 financial crisis until the end of the bailout program in 2014. Specifically, it examines the austerity measures according to the four retrenchment variables proposed in Chapter II (Table 1). It analyzes not only which austerity measures were adopted, but also "by whom" and "when" they were imposed or adopted.

\section{The prelude of Portugal's financial crisis (2008-2009)}

The 2008 financial crisis and a combination of several other factors related to the functioning of the EMU and its single currency have directly influenced the beginning of the rise of the Portuguese debt that began in 2010. While social citizenship rights have not been subject to 
the paradox of thrift in 2008-2009, the public deficit and debt have directly influenced the allocation of funding towards the welfare state, and the consequent restriction in access to social citizenship rights in Portugal. The paradox of thrift (or paradox of saving) was an argument made by John Maynard Keynes to explain the belief that economic growth is determined by the rate of saving or capital accumulation (Keynes, 1936). Thus, I consider the analysis of the retrenchment of the welfare state in Portugal under the paradigm of austerity of significant importance. Why is this so? It is important because the politics of austerity represented a combined effect of reducing public expenditure on cash benefits of social citizenship, but also of changing the degree of decommodification (conditionality) of such benefits - eligibility, coverage of the risks, duration and generosity (see Table 1). People who are dependent on the cash benefits of social citizenship - social assistance, unemployment insurance and old-age pensions, have decreased their degree of decommodification as a result of the cuts and changes imposed on the rights and entitlements of social citizenship. Public health care services and education also became a target to reduce the expenditures of public welfare (Evers \& Guillemard, 2013; Ferguson et al., 2002; Ferguson et al., 2018; Gilbert, 2013; Harris, 2014; Pierson, 2001).

Table 3 - Portugal's Government Deficit as a \% of GDP (1997-2008)

\begin{tabular}{llllllllllll}
\hline 1997 & 1998 & 1999 & 2000 & 2001 & 2002 & 2003 & 2004 & 2005 & 2006 & 2007 & 2008 \\
\hline-3.70 & -4.39 & -3.03 & -3.21 & -4.79 & -3.34 & -4.42 & -6.19 & -6.19 & -4.33 & -3.01 & -3.77 \\
\hline
\end{tabular}

Source: OECD, 2018, General government deficit (indicator). doi: 10.1787/77079edb-en (Accessed on March 27, 2018)

In 2007, prior to the 2008 financial crisis, Portugal had a public deficit of $-3.01 \%$ of GDP and a public debt of 78.1\% of GDP (OECD, 2018a, 2018b). Tables 3 and 4 show the evolution of 
Portugal's public deficit and public debt as a percentage of GDP since the period prior to when the SGP entered into force, which has occurred in 1998 (the preventive arm of the SGP) and 1999 (the corrective arm of the SGP) (Eur-Lex, 1997c, 1997d).

Table 4 - Portugal's General Government Debt as a \% of GDP (1997-2008)

\begin{tabular}{llllllllllll}
\hline 1997 & 1998 & $\mathbf{1 9 9 9}$ & $\mathbf{2 0 0 0}$ & $\mathbf{2 0 0 1}$ & $\mathbf{2 0 0 2}$ & $\mathbf{2 0 0 3}$ & $\mathbf{2 0 0 4}$ & $\mathbf{2 0 0 5}$ & $\mathbf{2 0 0 6}$ & $\mathbf{2 0 0 7}$ & $\mathbf{2 0 0 8}$ \\
\hline 66.6 & 65.3 & 62.5 & 62.0 & 63.5 & 66.8 & 70.6 & 76.7 & 80.0 & 79.4 & 78.1 & 82.8 \\
\hline
\end{tabular}

Source: OECD, 2018, General government debt (indicator). doi:10.1787/a0528cc2-en (Accessed on March 27, 2018)

As already explored, the politics of the "consolidation state" highlighted by Streeck (2014) began as a result of the transformation of the so-called "tax-state" into the "debt-state". Since the mid-1980s, OECD industrialized economies started to finance their public expenditure by borrowing from financial markets. Although Portugal benefited from European funding prior to and after joining the EU in 1986, the structural gaps in the Portuguese economy and society, as a result of its late democratic and capitalist development forced the country to pursue the same EU market-oriented capitalist rules and procedures adopted by stronger EU economies, i.e. Germany and France.

The preventive arm of the SGP, under its Article 3, No. 1 (Council Regulation No. 1466/97) requires that member states must submit their stability and convergence programs annually with a clear and consistent description of their budgetary and economic policy measures to achieve the aims of budgetary consolidation and sustainable growth. This is done through the definition of MTOs (Medium-Term Budgetary Objectives) (Eur-Lex, 1997c, 2005a). 
In order to analyze the process of welfare retrenchment in Portugal under the paradigm of austerity between 2008 and 2014 and how social citizenship rights coped with the budgetary discipline (known as austerity measures) imposed by the SGP rules and the MoU from the Troika, I will begin by detailing the budgetary and economic policy measures proposed by the Portuguese government in its annual Stability Programme (known in Portugal as Programa de Estabilidade e Crescimento), submitted to the European Commission under the MTOs criteria defined by the Council Regulations No. 1466/97 and No. 1467/97 later amended by the Council Regulation No. 1055/2005 and No. 1056/2005 (Eur-Lex, 1997c, 1997d, 2005a, 2005b).

The Stability Programme (SP) submitted by the Portuguese government for the period 2007-2011 provides an important account of the Portuguese economy, its budgetary commitments and welfare state reforms adopted or proposed prior to and after the 2008 financial crisis, particularly the 2010 European debt crisis that has hit the Portuguese financial sector and its public debt hard (European Commission, 2007).

Table 5 - Portugal's Unemployment Rate as a \% of Labour Force (1998-2008)

\begin{tabular}{llllllllllll}
\hline 1997 & 1998 & 1999 & 2000 & 2001 & $\mathbf{2 0 0 2}$ & $\mathbf{2 0 0 3}$ & $\mathbf{2 0 0 4}$ & $\mathbf{2 0 0 5}$ & $\mathbf{2 0 0 6}$ & $\mathbf{2 0 0 7}$ & $\mathbf{2 0 0 8}$ \\
\hline--- & 5.07 & 4.52 & 4.03 & 4.01 & 4.99 & 6.26 & 6.62 & 7.58 & 7.65 & 7.96 & 7.55 \\
\hline
\end{tabular}

Source: OECD, 2018, Unemployment rate (indicator). doi: 10.1787/997c8750-en (Accessed on March 27, 2018)

The slowdown of the economy also influenced the rise of unemployment. In 2007, prior to the crisis, Portugal had an unemployment rate of 7.96\% of its labour force (Table 5) (OECD, 2018c). Although the rate of unemployment increased, the rise of unemployment, the public social 
spending in 2007 dropped to $21.77 \%$ of GDP when compared with the two previous years (Table 6) (OECD, 2018d).

The updated version of the Stability Programme 2007-2011 approved by the Portuguese parliament on December 2007 outlines Portugal's obligations under the SGP rules (Eur-Lex, 1997c, 1997d, 2005a, 2005b; European Commission, 2007). This annual program takes into account the budgetary consolidation undertaken since 2005, the year when the Socialist Party (PS) headed by José Sócrates won a parliamentary majority government (121 of 230 seats). This program, prepared by the Portuguese government and submitted to the European Commission, provides evidence about the structural measures proposed and those adopted to reduce public expenditure, particularly on social transfers towards the welfare state. The program assumes clearly that its end goal is the consolidation of the reduction of public deficit and debt initiated in 2005 to be achieved through the reform of the social security and public health systems.

Table 6 - Portugal's Public Social Spending as a \% of GDP (1997-2008)

\begin{tabular}{llllllllllll}
\hline 1997 & 1998 & 1999 & $\mathbf{2 0 0 0}$ & $\mathbf{2 0 0 1}$ & $\mathbf{2 0 0 2}$ & $\mathbf{2 0 0 3}$ & $\mathbf{2 0 0 4}$ & $\mathbf{2 0 0 5}$ & $\mathbf{2 0 0 6}$ & $\mathbf{2 0 0 7}$ & $\mathbf{2 0 0 8}$ \\
\hline 16.44 & 16.83 & 17.24 & 18.51 & 19.00 & 20.52 & 21.36 & 21.69 & 22.33 & 22.06 & 21.77 & 22.22 \\
\hline
\end{tabular}

Source: OECD, 2018, Portugal's social spending (indicator). doi: 10.1787/7497563b-en (Accessed on March 27, 2018)

The program defined a forecast public debt for 2007 of $64.4 \%$ of GDP with the aim of achieving 56.7\% of GDP in 2011 (European Commission, 2007, p. iii). Table 4 shows that by the end of 2007, Portugal's official public debt was in fact $78.1 \%$ of GDP. Structural factors like the aging of the population were described to justify the structural reforms carried out in order to achieve the so-called "sustainability" of the welfare state. In its executive summary, the Stability 
Programme 2007-2011 (European Commission, 2007, p. iv) states that "the importance attributed by the Portuguese Government to the budgetary consolidation process has created the conditions for Portuguese citizens to better understand the importance of the quality of public finances." It is affirmed that budgetary consolidation creates awareness for sound public finances among citizens.

The program analyzes five main pillars - economic outlook, general government balance and debt, sensitivity analysis and comparison with December 2006, sustainability of public finances, and quality of public finances. The pillar "Economic Outlook" describes the economic environment of the first half of 2007 as one marked by sound growth of most of the economy. However, the second half of 2007 was affected by the US subprime mortgage crisis. For this reason, the predictions made for 2008 and 2009 became elusive. The estimated macroeconomic indicators outlined in the report for 2007 and 2008 on the unemployment rate were $7.8 \%$ (2007) and $7.6 \%$ (2008). The forecast for the following years were even more ambitious $-7.2 \%$ (2009), 6.9\% (2010) and 6.6\% (2011) (European Commission, 2007, p. 4).

The Stability Programme 2007-2011 also mentioned that 2007 marked the entry into force of the reforms adopted in the general stream of the social security scheme along with their adaption to the special public scheme of the civil servants. Such changes aimed to improve the sustainability of the public pension system, particularly with its aging population. The macroeconomic measures undertaken were also aimed at strengthening the sustainability of the SNS (National Health Care System).

The second pillar analyzed by the Stability Programme (2007-2011) was the "General Government Balance and Debt." This pillar provides evidence about the budgetary goals undertaken since 2005. It is affirmed that the objectives of budgetary consolidation planned and undertaken since 2005 have been achieved - reduction of the public deficit to 3\% of GDP between 
2005-2007. This shows that prior to the 2008 financial crisis, Portugal's public deficit was in line with the SGP rules to achieve a public deficit of 3\% of GDP (Eur-Lex, 1992a, 1992b, 1997c, 1997d, 2005a, 2005b). However, the forecast outlined for 2008, 2009 and 2010 failed as a result of the crisis. The predictions of economic growth for the 2008-2011 period were expected to lead to a decline of the public debt to GDP ratio to $64.4 \%$ in 2007 and to $56.7 \%$ in 2011 . In fact, as Table 4 shows, the official public debt to GDP ratio was $78.1 \%$ (European Commission, 2007).

As for social citizenship rights, the program outlines the reforms made to the social security and public health systems. In early 2007, a social security framework (Law 4/2007 of January 16) came into force (DRE, 2007a). These reforms reduced the transitory period to the new pension calculation formula (called sustainability factor), introduced additional penalizations for early retirement and a new pension update rule. The new framework (Law No. 4/2007 of January 16) also included the intention to create (in 2008) a voluntary public capitalization scheme (Article 82) in order to boost the pension income and reduce the impact of the sustainability factor (European Commission, 2007). Another reform undertaken in 2007 was the changes adopted to the social security scheme for public servants (called Caixa Geral de Aposentações). This pension scheme for public servants merged with the general social security scheme, entering into force in 2008 (Law No. 56/2007 of August 31) (DRE, 2007b). Some of the measures introduced to the new social security sub-system for civil servants were: refusal of new memberships to the former scheme for civil servants; the definition of convergence mechanisms; a new pension calculation formula for civil servants registered into the pool up to August 31, 1993; the introduction of the sustainability factor on new pension retirements (pension value is indexed to the average of life expectancy - 65 years in 2008); annual updates for old-age and disability pensions based on the reference of the consumer price index of the previous year; an additional penalty for early 
retirement (reduction of $0.5 \%$ for each month taken); and an award bonus for extending working life (DRE, 2007b). Although the public pension system underwent through extensive policy reforms, such measures would only produce effect on the long-term pension expenditure (2040 onwards).

Similarly, the Stability Programme (2007-2011) addresses the sustainability of the National Health Care System, known as SNS (European Commission, 2007, p. 25). The main reform outlined was the transformation of public hospitals into corporate public enterprises. In 2007, ten new hospitals moved into that corporate management system. In the program, it is reported that moving public hospitals into corporate public enterprises will promote efficiency and quality of the healthcare provided. While the financial performance described indicates savings on the cost structure, the cost of goods sold and the cost of suppliers, the external services and the new hirings were considered positive results for service users - reduction of both surgery waiting lists and times (European Commission, 2007, p. 27). The direct impact on the SNS co-payments paid by service users on primary and emergency care is not specified. According to the data provided, the SNS had a surplus of approximately $€ 104$ million in 2006 (European Commission, 2007, p. 26).

The 2007 government budgetary performance and the budget implementation for 2008 were also addressed by the Stability Programme (2007-2011). When the updated version of the program was prepared and approved by Parliament, the forecast of public deficit for 2007 was $3 \%$ as a percentage of GDP (see also Table 3), while the prediction for 2008 was $-2.4 \%$ of GDP. The reference values for the following years were even more ambitious: a public deficit of $-1.5 \%$ of GDP in 2009 and $-0.4 \%$ of GDP in 2010 (European Commission, 2007, p. 29). 
The impact of the social transfers (as a \% of GDP) in the 2007 public budget were $18.6 \%$ in $2006,19.0 \%$ in 2007 (forecast) and $19.1 \%$ for 2008 (forecast). I have already provided, in Table 6 , the official OECD data on Portugal's public social spending as a \% of GDP. Table 6 shows that the official public social spending was considerably higher in 2007 and 2008. While the program has provided a forecast for 2007 and 2008, it acknowledges that the rise of social transfers results from the increase in pension expenditure and on the development of social transfers in kind (as services) between 2006 and 2008 (European Commission, 2007, p. 30).

The MTOs (Medium Term Objectives), required under the preventive arm of the SGP (Article 3, No. 1 of the Council Regulation No. 1466/97) were also being addressed. They consisted of a clear and consistent description of the budgetary and economic policy measures to achieve the preventive aims of budgetary consolidation and sustainable growth (Eur-Lex, 1997c, 2005a). As I mentioned earlier, the preventive arm of the SGP (Council Regulation No. 1466/97) requires the definition of MTOs, defined in structural terms and updated every 3 years or more frequently, if a member state is facing significant structural reforms (Eur-Lex, 1997c). The projections for MTOs made in 2005 defined an objective for the structural public deficit of $-0.5 \%$ of GDP to be achieved by 2010. The projections made at the end of 2007 by the Stability Programme (2007-2011) were indicating compliance with the objectives made in 2005. The projections made, if achieved, were representing an impact of $4.7 \%$ in the reduction of the structural public deficit. In addition, the projections also made for public debt were also in line with the SGP debt ceilings of a maximum of $60 \%$ public debt (a forecast of $59.8 \%$ of GDP for 2010 and 56.7\% of GDP in 2011) (Eur-Lex, 1997b, 1997c, 2005a). Such consolidation, as described in the Stability Programme (2007-2011) was not achieved through substantial cuts to social transfers (social citizenship rights) since the structural reforms conducted on the public 
pension system would produce long-term effects on public expenditure, as stated by the program (European Commission, 2007, p. 32).

Therefore, the pillar "Sustainability of Public Finances" outlines and discusses the main reforms on the social security system described earlier, particularly public pensions expenditure. According to the program, those reforms have been recommended by the "Working Group on Ageing Populations and Sustainability (AWG) that assists the Economic Policy Committee (EPC) of the European Union's Economic and Financial Affairs Council (ECOFIN)" (European Commission, 2007, p. 43).

Following the mandatory annual update of Portugal's medium-term fiscal programme, called the Stability Programme, the European Commission and the ECOFIN Council are required to provide an opinion and assessment on the budgetary strategy and policies, under the preventive and corrective arms of the SGP (Eur-Lex, 1997c, 1997d, 2005a, 2005b). Thus, after Portugal submitted its annual Stability Programme 2007-2011 on December 14, 2007, the European Commission provided a brief recommendation to the ECOFIN Council on Portugal's budgetary strategy and policies for 2007-2011 (European Commission, 2008a). The European Commission's opinion was made available on March 4, 2008. The European Commission's letter to the ECOFIN Council recognizes the fiscal consolidation achieved by Portugal and the proposed MTOs. The structural reforms and other temporary measures adopted or proposed by Portugal aiming to curb the public deficit and public debt were slightly achieved or have set the country into long-term corrective measures. Although Portugal proposed a macroeconomic scenario in the update of the Stability Programme (2007-2011), the European Commission raised concerns about the assumptions projected for GDP growth (European Commission, 2008a). The European Commission considered that some additional efforts were needed in order to reduce the risks of 
the public finance. For example, for the European Commission, the reforms of the public pension system may reduce the budgetary impact of aging in the long-term, but further progress with fiscal consolidation in needed immediately (European Commission, 2008a).

When analyzing the European Commission's technical assessment of Portugal's Stability Programme for 2007-2011, it is shown that Portugal's public finances are vulnerable and have been exposed to the wider reality of economy's competitiveness and fiscal imbalances (European Commission, 2008b). Since the introduction of the single currency Euro in 2001, Portugal encountered several fiscal and economic challenges that have directly affected its public finances. Its public expenditure declined considerably. According to the European Commission's technical assessment from February 27, 2008 (European Commission, 2008b), the Council (ECOFIN) placed Portugal under the "excessive deficit procedure" in September 2005, as per the SGP rules - Council Regulation No. 1467/97 (also known as the corrective arm of the SGP) later updated by the Council Regulation No. 1056/2005 (Eur-Lex, 1997d, 2005b). Under the SGP rules for the “excessive deficit procedure", Portugal was requested to reduce its public deficit by 2008 (see Table 3) (European Commission, 2008b).

Table 7 - Portugal's General Government Spending as a \% of GDP (1997-2008)

\begin{tabular}{llllllllllll}
\hline 1997 & 1998 & 1999 & 2000 & 2001 & $\mathbf{2 0 0 2}$ & $\mathbf{2 0 0 3}$ & $\mathbf{2 0 0 4}$ & $\mathbf{2 0 0 5}$ & $\mathbf{2 0 0 6}$ & $\mathbf{2 0 0 7}$ & $\mathbf{2 0 0 8}$ \\
\hline 42.45 & 42.70 & 42.55 & 42.64 & 44.11 & 43.42 & 45.32 & 46.06 & 46.68 & 45.24 & 44.49 & 45.34 \\
\hline
\end{tabular}

Source: OECD, 2018, General government spending (indicator). doi: 10.1787/a31cbf4d-en (Accessed on March 27, 2018)

Thus, the general government budgetary expenditure declined in 2006 (45.24\% of GDP) and in 2007 (44.49\% of GDP) when compared with 2005 (see Table 7) (European Commission, 
2008b; OECD, 2018e). The social expenditure has increased steadily between 2005 and 2007 (see Table 6) (OECD, 2018d). In terms of the long-term debt projections and the sustainability of public finances, the European Commission's technical assessment have made projections about Portugal's government social spending on key social citizenship rights based on the age-related spending (European Commission, 2008b).

According to the European Commission's technical assessment (European Commission, 2008b), the evolution of government social spending on public pensions, public healthcare and long-term care for the elderly will increase between 2004 and 2050 while the expenditure for public education and unemployment benefits will decrease. From this later group, the expenditure on public pensions is projected to be above the EU average (European Commission, 2008b, p. 46). Therefore, the European Commission's technical assessment concludes that, "the stability programme is consistent with a correction of the excessive deficit no later than 2008" (European Commission, 2008b, p. 6). For the European Commission, the lower projected economic growth made in late 2007 leaves Portugal at medium risk in terms of its public expenditure vis-à-vis public deficit and debt in early 2008.

On March 4, 2008, the ECOFIN Council issued its opinion on Portugal's Stability Programme 2007-2011 (Eur-Lex, 2008e; European Commission, 2007). The Council considered that Portugal has defined its MTOs and measures based on a macroeconomic scenario that takes into account certain assumptions on GDP growth. Thus, according to the ECOFIN Council, the projected budgetary consolidation can be less effective. However, the Council also states that the Stability Programme 2007-2011 is consistent with the European Commission's orientations and with the reforms being conducted (Eur-Lex, 2008e). Therefore, the Council has recommended that Portugal make additional efforts on fiscal consolidation by maintaining its expenditure moderation 
to reduce its public deficit and debt in order to end its deficit procedure (Eur-Lex, 2008e). This shows Portugal's path and effort to reduce its public deficit and debt before the 2008 financial crisis hit the EU banking system.

The next update on the Stability Programme for 2008-2011 was made in January 2009 and included new measures that have been proposed or introduced under the European Economic Recovery Plan, a European Commission's response to the 2008 financial crisis that was adopted by the European Commission in December 2008 (Eur-Lex, 2008f; European Commission. 2009a).

The last quarter of 2008 affected Portugal's economic and fiscal stability in an unprecedented way. The crisis marked the beginning of a snowball effect for Portugal regarding its financial stability and economic activity in general. In the Introduction of this dissertation, I have questioned if and how the banking system was responsible for the 2008 financial crisis that led to the 2010 European debt crisis? Blyth (2012) explained that, when the US investment bank Lehman Brothers collapsed on September 15, 2008, the entire global financial system immersed into a crisis of confidence and liquidity among national banks and international and private investors such as pension funds, European banks and governments. Such "toxic" mortgage debt debilitated even more the accumulated losses of the Portuguese bank BPN, losses that occurred mostly prior to the 2008 global financial crisis. Thus, in November 2008, Portugal nationalized the BPN bank to protect depositors and strengthen the capital ratios of the bank (Blyth, 2013). For that reason, the crisis affected and influenced the 2009 state budget directly and consequently the update of the Stability Programme for 2008-2011, that was made in January 2009 after reflecting the required amendments made to the 2009 public budget. Thus, the Stability Programme for 20082011 represented a shift after two years of budgetary consolidation and key structural reforms initiated in 2005 (European Commission, 2009a). The update to the Stability Programme for 2008- 
2011 defines the new focus of Portugal's economic policy - strengthen financial stability and a budgetary effort to support investment, employment, and vulnerable people (European Commission, 2009a).

Table 8 - Portugal's Household Disposable Income - Net, \% of Annual growth rate (2007-2015)

\begin{tabular}{lllllllll}
\hline $\mathbf{2 0 0 7}$ & $\mathbf{2 0 0 8}$ & $\mathbf{2 0 0 9}$ & $\mathbf{2 0 1 0}$ & $\mathbf{2 0 1 1}$ & $\mathbf{2 0 1 2}$ & $\mathbf{2 0 1 3}$ & $\mathbf{2 0 1 4}$ & $\mathbf{2 0 1 5}$ \\
\hline 1.22 & 1.09 & 1.74 & 0.71 & -5.57 & -4.80 & -0.71 & -1.24 & 1.67 \\
\hline
\end{tabular}

Source: OECD, 2018, Portugal's household disposable income. doi: 10.1787/dd50eddd-en (Accessed on June 5, 2018)

The beginning of the crisis in 2008 immediately affected Portugal's household disposable income (net \% annual real growth) when compared to the previous year, which can be analyzed through the "OECD household disposal income indicator" on Table 8 (OECD, 2018f). The GDP growth forecasts made in the previous Stability Programme 2007-2011 have become infeasible (European Commission, 2007).

\begin{tabular}{cccccccccc}
\multicolumn{1}{c}{ Table 9 } & - Portugal's Real GDP Forecast & - Total, \% of Annual growth rate (2007-2015) \\
\hline $\mathbf{2 0 0 7}$ & $\mathbf{2 0 0 8}$ & $\mathbf{2 0 0 9}$ & $\mathbf{2 0 1 0}$ & $\mathbf{2 0 1 1}$ & $\mathbf{2 0 1 2}$ & $\mathbf{2 0 1 3}$ & $\mathbf{2 0 1 4}$ & $\mathbf{2 0 1 5}$ \\
\hline 2.5 & 0.2 & -3.0 & 1.9 & -1.8 & -4.0 & -1.1 & 0.9 & 1.8 \\
\hline
\end{tabular}

Source: OECD, 2018, Real GDP forecast (indicator). doi: 10.1787/1f84150b-en (Accessed on June 5, 2018)

The OECD "Real GDP forecast indicator" (Table 9) shows that Portugal's GDP fell abruptly in 2008 to $0.2 \%$ when compared with the $2.5 \%$ verified in 2007 (OECD, 2008g). A 
combination of several factors explains the decline of both, real gross GDP and consequently of the household disposable income.

An important component of the so-called "Debt State", the current paradigm of marketoriented capitalist economies as Streeck (2014) explained, is the borrowing of money from financial markets to finance government public expenditures. The first requirement to achieve this task is the cost of borrowing money expressed through both short- (government bonds normally maturing in three months) and long-term (government bonds maturing in ten years) interest rates. Portugal's both short- and long-term interest rates rose sharply between 2005 and 2008, particularly in 2008 as a result of the financial crisis (see Tables 10 and 11) (OECD, 2018h, 2018i).

Therefore, the rise of interest rates for a country like Portugal can directly undermine the balance of public accounts and the performance of the economy, for example, through inflation, unemployment, taxation, labour performance, private consumption, the rise of inequality and poverty, and disinvestment and austerity measures on welfare programs and services, among others (Blyth, 2013; Lapavitsas et al., 2012; Schafer \& Streeck, 2013; Streeck, 2014).

Table 10 - Portugal's Short-Term Interest Rates - \% per annum (1997-2008)

\begin{tabular}{llllllllllll}
\hline 1997 & $\mathbf{1 9 9 8}$ & $\mathbf{1 9 9 9}$ & $\mathbf{2 0 0 0}$ & $\mathbf{2 0 0 1}$ & $\mathbf{2 0 0 2}$ & $\mathbf{2 0 0 3}$ & $\mathbf{2 0 0 4}$ & $\mathbf{2 0 0 5}$ & $\mathbf{2 0 0 6}$ & $\mathbf{2 0 0 7}$ & $\mathbf{2 0 0 8}$ \\
\hline 5.74 & 4.31 & 2.96 & 4.39 & 4.26 & 3.32 & 2.33 & 2.11 & 2.18 & 3.08 & 4.28 & 4.63 \\
\hline
\end{tabular}

Source: OECD, 2018, Portugal's short-term interest rates (indicator). doi: 10.1787/2cc37d77-en (Accessed on June 5, 2018)

So, how has public debt and interest rates affected Portugal in the beginning of the 2008 financial crisis? What measures were proposed and adopted by the Portuguese government? The analysis of the Stability Programme 2008-2011 offers a sneak peek account of the initial impact 
of the crisis and shows if and how the key structural reforms initiated in 2005 were conditioned (European Commission, 2009a). Despite the pressure of the 2008 financial crisis, and the new efforts to strengthen financial stability, the structural reforms in the social security and public health care systems initiated before the crisis to achieve a medium/long-term budgetary consolidation have continued. In October 2008, a new cycle of the National Reforms Plan for 2008-2010 was approved (European Commission, 2009a).

\begin{tabular}{llllllllllllll}
\hline \multicolumn{10}{c}{ Table } & 11 & - Portugal's Long-Term Interest Rates $-\%$ per annum (1997-2008) \\
\hline $\mathbf{1 9 9 7}$ & $\mathbf{1 9 9 8}$ & $\mathbf{1 9 9 9}$ & $\mathbf{2 0 0 0}$ & $\mathbf{2 0 0 1}$ & $\mathbf{2 0 0 2}$ & $\mathbf{2 0 0 3}$ & $\mathbf{2 0 0 4}$ & $\mathbf{2 0 0 5}$ & $\mathbf{2 0 0 6}$ & $\mathbf{2 0 0 7}$ & $\mathbf{2 0 0 8}$ \\
\hline 6.36 & 4.88 & 4.78 & 5.59 & 5.16 & 5.01 & 4.18 & 4.14 & 3.44 & 3.91 & 4.42 & 4.52 \\
\hline
\end{tabular}

Source: OECD, 2018, Portugal's long-term interest rates (indicator). doi: 10.1787/662d712c-en (Accessed on June 5, 2018)

Through the adoption of a new approach to address the early effects of the 2008 financial crisis, Portugal carried out a budgetary stimulus to boost its debilitated economy. In addition to the sustainability of the social security and public health systems initiated in 2005, the Portuguese government proposed and adopted in 2008 a set of new measures to support families, to boost the economy and to combat the early effects of the crisis (European Commission, 2009a). For example, the government's response to fighting poverty entailed changes in the eligibility criteria of the so-called "Complemento Solidário para Idosos" (CSI). The CSI is a "Guaranteed Income Supplement" for seniors with a lower income. Other measures adopted were to reinforce the disability benefits for recipients with substantial mental or physical impairment and the employment incentives and benefits for people on social assistance (Rendimento Social de Inserção, or simply RSI). The government also introduced additional measures for families and 
children such as raising family allowances, creating school transportation and a special bus pass for students between 4 and 18 years of age (European Commission, 2009a). Although a widerange of measures was implemented, the direct budgetary impact of such measures adopted to mitigate the beginning of the financial crisis was of $0.07 \%$ of GDP on anti-poverty measures and of $0.12 \%$ of GDP on measures to protect families and children (European Commission, 2009a, p. 24). In terms of investment and employment, the Portuguese government also established a scale of structural anti-cyclical measures aiming to attenuate the effects on the crisis on investment and employment. On January 19, 2009, a draft bill was discussed and approved by Parliament to establish the "Investment and Employment Initiative" (IEI) Program 2009 (Iniciativa para o Investimento e Emprego 2009). The IEI contained five structural measures with several projects and actions such as the ones for "protecting employment and strengthening social protection" with an expected budgetary impact of $0.18 \%$ of GDP for 2009 (European Commission, 2009a, p. 25). Those measures included rebates of $3 \%$ on employment insurance premiums for employers (micro and small businesses) who retained their employees with more than 45 years of age. According to the Stability Programme (2008-2011), the projection for this measure was that it would support 513,000 thousand workers with an average value of $€ 331$ Euros per job position (European Commission, 2009a, p. 30). In addition, a six-month temporary measure for 2009 was also introduced to support businesses and workers who were laid off through the "QualificationEmployment measure” (Medida Qualificação-Emprego). This measure aimed to support 450 businesses and around 2,000 workers (European Commission, 2009a). Support for youth through 12,000 field placements was also offered in order to create conditions for them to gain access to the job market, particularly those with higher education. In addition, $€ 2,000$ Euros were offered to each employer for recruiting those youths. A two-year exemption from contributions to 
employment insurance premiums for employers who filled job positions with no end was also offered (European Commission, 2009a). These temporary measures only came into force in 2009. Similarly, measures to support the long-term unemployment of adults over 55 years of age were also created. Social assistance was also extended, through an eligibility for a 6 months benefit extension (in $60 \%$ of the reference value) for those beneficiaries who exceeded their unemployment insurance benefits (European Commission, 2009a).

Because this dissertation is focused on the process of retrenchment of the welfare state under the paradigm of austerity, the analysis of the government budget offers an important method of going beyond the evidence to assess the key constructs of budgetary consolidation, particularly the process of welfare retrenchment under the SGP and MoU. Therefore, the Stability Programme 2008-2011 explores the budgetary implementation carried out in 2008 and the State budget for 2009 (European Commission, 2009a). In July 2008, Portugal successfully managed to achieve the closure of the excessive deficit procedure placed on it in 2005 under the Treaty of Maastricht and the SGP rules (Eur-Lex, 1992a, 1997c, 1997d, 2005b). Following such rules, the Portuguese government managed to meet the deficit ceiling of -3\% to GDP by 2008 as shown in Table 3 (3.01\% in 2007) (Eur-Lex, 1992a, 1992b, 1997c, 1997d, 2005a, 2005b). Overall, the total public expenditure increased from 2007 to 2008 (see Table 7). Furthermore, given the measures described above, public social expenditure also increased from 2007 to 2008 (see Table 6). Despite the budgetary consolidation achieved between 2005 and 2008, the beginning of the 2008 financial crisis changed the MTOs proposed in the previous Stability Programme (2007-2011) (European Commission, 2007). The 2008-2011 update of the Stability Programme proposed a new orientation and approach for Portugal's MTOs. As the Portuguese government was no longer committed to 
achieve the financial stability under the MTOs, it became possible to concentrate on investment and social protection (European Commission, 2007).

Thus, as Illustration 1 shows, Portugal's MTOs forecast for 2009 set an inversion of the ongoing budgetary consolidation process. The 2008 financial crisis forced the Portuguese government to move into an opposite direction to minimize the early effects of the crisis, following the European Economic Recovery Plan adopted by the European Commission (Eur-Lex, 2008f). Therefore, the scenario in the report annexed to the State budget for 2009 about the projections of the social security reforms initiated in 2007 suggests that, despite the projections that were made based on certain underlying scenarios with a higher real GDP growth rate, the financial sustainability of Portugal's social security system had been strengthened (European Commission, 2009, p. 47).

\section{Illustration 1 - Portugal's Budgetary Consolidation Programming in \% of GDP (2006-2011)}

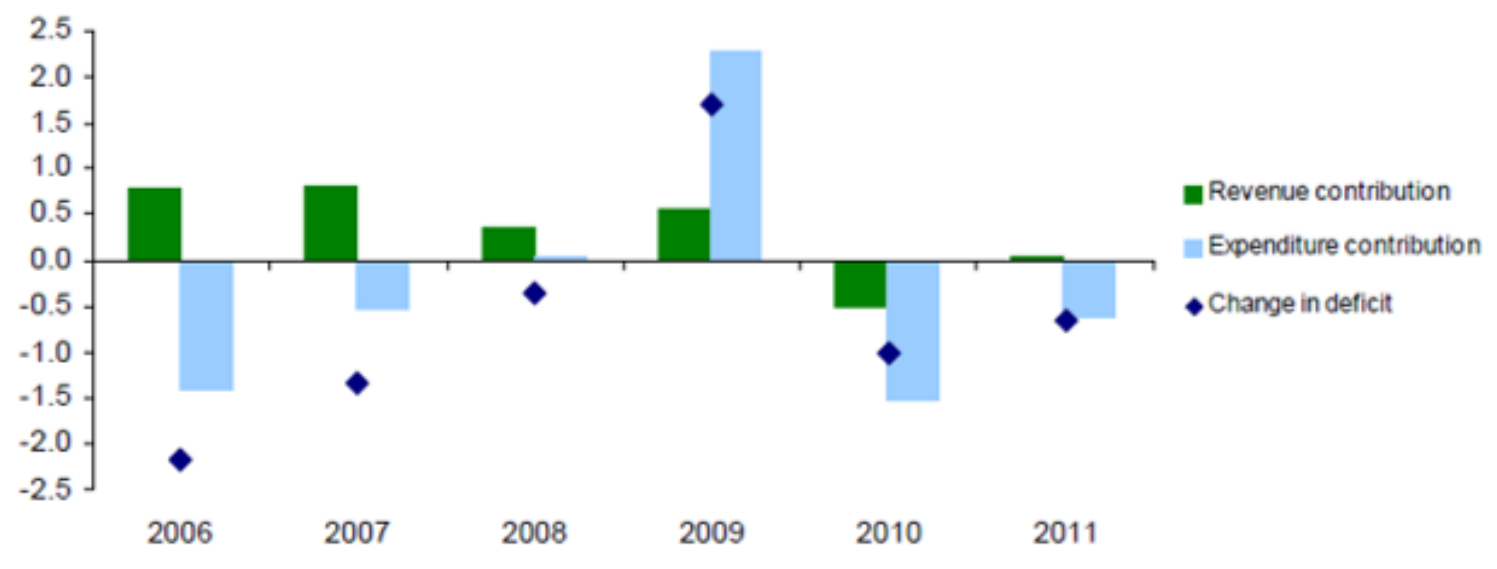


On February 25, 2009, the European Commission requested a Council's opinion by offering a brief recommendation on the update of the Stability Programme 2008-2011 (European Commission, 2009b). According to the recommendation, Portugal's GDP stagnated in 2008 as a result of the 2008 financial crisis and the stagflation of the economy in the EU. In addition, Portugal's external imbalances widened, leading to the growth of indebtedness and the consequent rise in interest payments in the financial markets (European Commission, 2009b). In spite of that, the European Commission's recommendation acknowledged that "the [2008-2011] programme aims at a significant temporary fiscal impulse in 2009 in line with the EERP [European Economic Recovery Plan], which represents an adequate response to the economic downturn." (European Commission, 2009a, 2009b). The European Economic Recovery Plan was a coordinated fiscal stimulus and financing investment plan adopted by the European Commission to respond to the 2008 financial crisis (Eur-Lex, 2008f). On March 11, 2009, the European Commission released its technical assessment on the budgetary strategy presented by Portugal's Stability Programme 20082011 as well as Portugal's macro-economic performance (European Commission, 2009c). In terms of Portugal's macroeconomic developments and scenario in 2008 and 2009, the European Commission has foreseen different projections somehow less optimistic than those made by the Portuguese authorities in the Program. However, the new budgetary strategy for 2008 is characterized by a significant fiscal expansion and consequently a rise of public deficit (European Commission, 2009a, 2009c). Some of the risks for the proposed budgetary target have been highlighted by the European Commission - weaker economic growth, fiscal outturns and uncertainty of the impact of corrective effort (European Commission, 2009c, p. 12). The uncertainty of the effectiveness of the fiscal stimulus and investment planned may generate further constraints and indebtedness. In terms of social transfers, the technical assessment highlights the 
fact that the reforms undertaken on pensions, particularly the early retirement and the voluntary contribution to private funds rely on individuals' decisions, somehow being "beyond government control" (European Commission, 2009c, p. 12). In addition, it has been argued that, "[o]ther social transfers could also be put under increasing pressure by growing levels of unemployment and poverty" (European Commission, 2009c, p. 12).

On March 10, 2009, the ECOFIN Council issued its assessment of the Stability Programme 2008-2011 (Eur-Lex, 2009; European Commission, 2009a). The Council recognized that the fiscal stimulus proposed by Portugal in the Stability Programme 2008-2011 for 2009 follows the recommendations defined by the EERP [European Economic Recovery Plan] in December 2008 and represents an adequate response to the early effects of the 2008 financial crisis and its consequent economic downturn (Eur-Lex, 2008e; European Commission, 2009a). The Council also mentioned that while adopting a fiscal stimulus for 2009, Portugal should avoid any further deterioration of public finances during 2009 in order to continue the budgetary consolidation in 2010 (Eur-Lex, 2009).

Thus, it is shown that the early responses to the 2008 financial crisis proposed by the European Commission through the EERP led to the deterioration of Portugal's public finances in 2009. The budgetary stimulus adopted by Portugal in 2009 under the European Commission's recommendations threw away the consolidation efforts made between 2005-2008.

\section{Austerity hits Portugal (2010-2011)}

The politics of austerity in Portugal began earnest in 2010. Following the years of budgetary consolidation which were the result of the excessive deficit procedure established in 
2005 under the Treaty of Maastricht and the SGP rules, the 2008 financial crisis and the consequent snowball effect of the European debt crisis pushed Portugal into the austerity saga (Eur-Lex, 1992a, 1997d, 2005b). By 2010, the pressure from the financial markets and the EU forced Portugal to adopt austerity measures as a response to the European demands.

\section{PEC I (Stability Programme 2010-2013)}

In March 2010, the Portuguese Socialist government approved the Stability Programme for 2010-2013 known in Portugal as PEC I (European Commission, 2010a). This new update marked a turning point in Portugal's political-austerity debate and, consequently, in its economy and society. In 2009, the Portuguese economy was severely hit by the effects of the financial crisis at the international level. Its annual growth rate decreased consistently in the first three quarters of 2009. As shown in Table 9, in 2009, the annual growth rate decreased to $-3.0 \%$ when compared with the $0.2 \%$ registered in 2008 (OECD, 2018g). The public deficit also fell from $-3.77 \%$ of GDP in 2009 (Table 3) to $-9.81 \%$ of GDP in 2009 (Table 12) and the public debt was aggravated from 82.8\% of GDP in 2009 to $96.1 \%$ of GDP in 2010 (Table 13) (OECD, 2018j, 20181).

Table 12 - Portugal's Government Deficit as a \% of GDP (2009-2015)

\begin{tabular}{lllllll}
\hline $\mathbf{2 0 0 9}$ & $\mathbf{2 0 1 0}$ & $\mathbf{2 0 1 1}$ & $\mathbf{2 0 1 2}$ & $\mathbf{2 0 1 3}$ & $\mathbf{2 0 1 4}$ & $\mathbf{2 0 1 5}$ \\
\hline-9.81 & -11.17 & -7.38 & -5.66 & -4.84 & -7.17 & -4.40 \\
\hline
\end{tabular}

Source: OECD, 2018, General government deficit (indicator). doi: 10.1787/77079edb-en (Accessed on March 27, 2018) 
Similarly, the effects of the crisis also rapidly influenced the rise of unemployment from $7.55 \%$ in 2008 (Table 5) to $9.43 \%$ in 2009 (Table 14) (OECD, 2018c, 2018m). As mentioned before, during 2009, Portugal set up an inversion in its budgetary consolidation process with a fiscal stimulus and investment (Illustration 1). However, the consequent rise of the public deficit and public debt in late 2009 and early 2010 (Tables 12 and 13) can be explained, in part, by the significant drop of tax revenues in 2009 (Table 15) (OECD, 2018n).

Table 13 - Portugal's General Government Debt as a \% of GDP (2009-2015)

\begin{tabular}{lcccccc}
\hline $\mathbf{2 0 0 9}$ & $\mathbf{2 0 1 0}$ & $\mathbf{2 0 1 1}$ & $\mathbf{2 0 1 2}$ & $\mathbf{2 0 1 3}$ & $\mathbf{2 0 1 4}$ & $\mathbf{2 0 1 5}$ \\
\hline 96.1 & 104.1 & 107.8 & 137.1 & 141.1 & 151.4 & 149.2 \\
\hline
\end{tabular}

Source: OECD, 2018, General government debt (indicator). https://data.oecd.org/chart/5ekX (Accessed on March 27, 2018)

In early 2010, the growing pressure from the EU towards Portugal was a consequence of the violation of the obligations to adopt and pursue sound fiscal policies and budgetary discipline under the Treaty of Maastricht and the SGP rules which define a maximum annual budget deficit of 3\% of GDP and a maximum of national debt of $60 \%$ of GDP (Eur-Lex, 1992a, 1992b, 1997c, 1997d, 2005a, 2005b, 2008c, 2008d).

Table 14 - Portugal's Unemployment Rate as \% of Labour force (2009-2015)

\begin{tabular}{lllllll}
\hline $\mathbf{2 0 0 9}$ & $\mathbf{2 0 1 0}$ & $\mathbf{2 0 1 1}$ & $\mathbf{2 0 1 2}$ & $\mathbf{2 0 1 3}$ & $\mathbf{2 0 1 4}$ & $\mathbf{2 0 1 5}$ \\
\hline 9.43 & 10.77 & 12.68 & 15.53 & 16.18 & 13.90 & 12.44 \\
\hline
\end{tabular}

Source: OECD, 2018, Unemployment rate (indicator). doi: 10.1787/997c8750-en (Accessed on March 27, 2018) 
As a result of such violations in the public debt and deficit (Table 12 and 13), the Stability Programme 2010-2013 adopted "a clear and serious budgetary consolidation strategy with the goal of reducing the General Government deficit to $2.8 \%$ of GDP by 2013 and controlling the growth of General Government debt, in order to reverse its current trend and reduce its ratio to GDP by 2013” (European Commission, 2010a, p. I).

Table 15 - Portugal's Tax Revenue as a \% of GDP (2007-2015)

\begin{tabular}{lllllllll}
\hline $\mathbf{2 0 0 7}$ & $\mathbf{2 0 0 8}$ & $\mathbf{2 0 0 9}$ & $\mathbf{2 0 1 0}$ & $\mathbf{2 0 1 1}$ & $\mathbf{2 0 1 2}$ & $\mathbf{2 0 1 3}$ & $\mathbf{2 0 1 4}$ & $\mathbf{2 0 1 5}$ \\
\hline 31.82 & 31.73 & 29.91 & 30.41 & 32.33 & 31.78 & 34.07 & 34.26 & 34.56 \\
\hline
\end{tabular}

Source: OECD, 2018, Tax revenue (indicator). doi: 10.1787/d98b8cf5-en (Accessed on June 5, 2018)

The Stability Programme (PEC I) 2010-2013 took into account the State Budget for 2010 (DRE, 2010; European Commission, 2010a). The reduction and control of expenditure adopted by the State Budget for 2010 was enormous in all areas. However, according to the State Budget (Law No. 3-B/2010 of April 28), the freezing of expenditure was not being applied to the expenditure on Higher Education and to the National Health Care System (SNS) (DRE, 2010). Despite that fact, the State Budget for 2010 introduced changes to the eligibility and conditionality of several social citizenship rights benefits - old-age pensions, disability etc. (DRE, 2010). Therefore, the Stability Programme 2010-2013 discussed and approved in March 2010 went even further than the cuts adopted by the State Budget for 2010. The austerity measures that were adopted on social citizenship rights were: a cap on expenditures with the GMI program (RSI); the speeding up of the convergence of the civil servants' pension scheme known as Caixa Geral de Aposentações (CGA) with the General Social Security scheme; changes to the unemployment insurance program in 
order to strengthen the incentives to work; and budgetary control of the National Healthcare Service (SNS) to ensure financial sustainability (European Commission, 2010, p. II). In addition, the use of means-testing (proof of means) criteria (Condição de Recursos) was also strengthened in order to determine the income and assets of all beneficiaries on social assistance and unemployment insurance (European Commission, 2010a). These austerity cuts were aimed at producing an impact on social expenditure of $-0.30 \%$ (GDP) in 2011, $-0.45 \%$ (GDP) in 2012 and $0.55 \%$ (GDP) in 2013 which represented an expenditure contraction of $€ 7100$ million in 2011, $€ 7000$ million in 2012 and $€ 6900$ million in 2013. It included a cap of $€ 400$ million in the GMI (RSI) in 2011 and $€ 370$ million in 2012 and in 2013. Expenditure on Health Care were also cut by $-0.20 \%$ (GDP) in $2011,-0.30 \%$ (GDP) in 2012 and $-0.39 \%$ (GDP) in 2013 while the measures for the speeding up of the convergence of the pension schemes represented a reduction of $-0.04 \%$ (GDP) in 2011, -0.05\% (GDP) in 2012 and $-0.07 \%$ in 2013 (European Commission, 2010a, p. VI).

Table 16 - Portugal's Public Social Spending as a \% of GDP (2009-2015)

\begin{tabular}{lllllll}
\hline 2009 & $\mathbf{2 0 1 0}$ & $\mathbf{2 0 1 1}$ & $\mathbf{2 0 1 2}$ & $\mathbf{2 0 1 3}$ & $\mathbf{2 0 1 4}$ & $\mathbf{2 0 1 5}$ \\
\hline 24.58 & 24.48 & 24.36 & 24.53 & 25.50 & 24.52 & 24.10 \\
\hline
\end{tabular}

Source: OECD, 2018, Portugal's social spending (indicator). doi: 10.1787/7497563b-en (Accessed on June 5, 2018)

As shown by the OECD public social spending indicator (2009-2015) for Portugal (Table 16), the official social expenditure in 2010 decreased from $24.58 \%$ (as a \% of GDP) in 2009 to $24.48 \%$ (as a \% of GDP) in 2010 (OECD, 2018o). This OECD indicator comprises cash benefits, direct in-kind provision of goods and services, and tax breaks with social purposes. 
Table 17 - Portugal's Public Pension Spending as a \% of GDP (2007-2013)

\begin{tabular}{lllllllll}
\hline $\mathbf{2 0 0 7}$ & $\mathbf{2 0 0 8}$ & $\mathbf{2 0 0 9}$ & $\mathbf{2 0 1 0}$ & $\mathbf{2 0 1 1}$ & $\mathbf{2 0 1 2}$ & $\mathbf{2 0 1 3}$ & $\mathbf{2 0 1 4}$ & $\mathbf{2 0 1 5}$ \\
\hline 10.35 & 10.87 & 11.83 & 11.99 & 12.67 & 13.00 & 13.95 & -- & -- \\
\hline
\end{tabular}

Source: OECD, 2018, Pension spending (indicator). doi: 10.1787/a041f4ef-en (Accessed on June 5, 2018)

Another measure proposed by PEC I was the speeding of the pension reforms initiated in 2007 to converge the civil servants' pension scheme (CGA) with the General Social Security scheme. The OECD indicator (Table 17) on public pension spending shows that, in 2009, the public pension spending (old-age and survivors) was $11.83 \%$, while in 2010 , it was $11.99 \%$ (OECD, 2018p).

Table 18 - Portugal's Public Unemployment Spending as a \% of GDP (2007-2013)

\begin{tabular}{lllllllll}
\hline $\mathbf{2 0 0 7}$ & $\mathbf{2 0 0 8}$ & $\mathbf{2 0 0 9}$ & $\mathbf{2 0 1 0}$ & $\mathbf{2 0 1 1}$ & $\mathbf{2 0 1 2}$ & $\mathbf{2 0 1 3}$ & $\mathbf{2 0 1 4}$ & $\mathbf{2 0 1 5}$ \\
\hline 1.139 & 0.876 & 1.166 & 1.235 & 1.194 & 1.540 & 1.608 & -- & - \\
\hline
\end{tabular}

Source: OECD, 2018, Public unemployment spending (indicator). doi: 10.1787/55557fd4-en (Accessed on June 5, 2018)

The OECD public unemployment spending indicator (Table 18) also shows that the expenditure from unemployment insurance in Portugal increased from 1.166\% (GDP) in 2009 to $1.235 \%$ (GDP) in 2010 (OECD, 2018q). As shown by the OECD family benefits public spending indicator (Table 19), Portugal's public expenditure on family and children allowances decreased in 2010 to $1.385 \%$ (GDP) when compared with the $1.446 \%$ (GDP) in 2009 (OECD, 2018r). 
Table 19 - Portugal's Family Benefits Public Spending as a \% of GDP (2007-2013)

\begin{tabular}{lllllllll}
\hline $\mathbf{2 0 0 7}$ & $\mathbf{2 0 0 8}$ & $\mathbf{2 0 0 9}$ & $\mathbf{2 0 1 0}$ & $\mathbf{2 0 1 1}$ & $\mathbf{2 0 1 2}$ & $\mathbf{2 0 1 3}$ & $\mathbf{2 0 1 4}$ & $\mathbf{2 0 1 5}$ \\
\hline 1.153 & 1.235 & 1.446 & 1.385 & 1.207 & 1.236 & 1.200 & -- & -- \\
\hline
\end{tabular}

Source: OECD, 2018, Family benefits public spending (indicator). doi: 10.1787/8e8b3273-en (Accessed on June 5, 2018)

Similarly, the OECD public spending indicator on incapacity (Table 20) shows that the public expenditure on incapacity benefits for people with disabilities or unable to work because of sickness and injury have decreased from $2.006 \%$ (GDP) in 2009 to $1.926 \%$ (GDP) in 2010 (OECD, 2018s).

Table 20 - Portugal's Public Spending on Incapacity as a \% of GDP (2007-2013)

\begin{tabular}{lllllllll}
\hline $\mathbf{2 0 0 7}$ & $\mathbf{2 0 0 8}$ & $\mathbf{2 0 0 9}$ & $\mathbf{2 0 1 0}$ & $\mathbf{2 0 1 1}$ & $\mathbf{2 0 1 2}$ & $\mathbf{2 0 1 3}$ & $\mathbf{2 0 1 4}$ & $\mathbf{2 0 1 5}$ \\
\hline 2.052 & 1.923 & 2.006 & 1.926 & 1.934 & 1.792 & 1.799 & -- & -- \\
\hline
\end{tabular}

Source: OECD, 2018, Public spending on incapacity (indicator). doi: 10.1787/f35b71ed-en (Accessed on June 5, 2018)

Finally, the OECD indicator on public spending on labour markets (Table 21), which includes the expenditure with all benefits offered by public employment services and related programs through field placements, job training and hiring incentives, shows that, the public spending on labour markets have decreased from 2.006\% (GDP) in 2009 to $1.926 \%$ (GDP) in 2010 (OECD, 2018t). 
Table 21 - Portugal's Public Spending on Labour Markets as a \% of GDP (2007-2015)

\begin{tabular}{lcccccccc}
\hline $\mathbf{2 0 0 7}$ & $\mathbf{2 0 0 8}$ & $\mathbf{2 0 0 9}$ & $\mathbf{2 0 1 0}$ & $\mathbf{2 0 1 1}$ & $\mathbf{2 0 1 2}$ & $\mathbf{2 0 1 3}$ & $\mathbf{2 0 1 4}$ & $\mathbf{2 0 1 5}$ \\
\hline 1.590 & 1.610 & 2.120 & 2.110 & 1.950 & 2.190 & 2.230 & 2.130 & 1.910 \\
\hline
\end{tabular}

Source: OECD, 2018, public spending on labour market (indicator). doi: 10.1787/911b8753-en (Accessed on June 5, 2018)

While the described OECD indicators offered clear evidence of the outcomes of public expenditure in Portugal, particularly in the year 2010 when the initial austerity measures were introduced by the Stability Programme 2010-2013, the detailed analysis of PEC I lends better support to analyze the developments of the Portuguese economy in 2009 and 2010 in order to extrapolate how the shrinking of the economy and the public indebtedness have influenced the retrenchment of the welfare state under austerity (European Commission, 2010a).

Thus, the economic outlook of PEC I provides details about the development of the Portuguese economy since the beginning of the 2008 financial crisis, particularly the contraction which occurred in 2009 and pushed Portugal's GDP down to a negative $-3.0 \%$ of GDP rate (Table 9). The stimulus measures undertaken in 2009 that were described above on the update to the Stability Programme 2008-2011 were not as significant as forecasted (European Commission, 2009a). In 2009, the unemployment rate rose from $7.55 \%$ in 2008 to $9.43 \%$ in 2009 (Tables 5 and 14) (OECD, 2018c, 2018m).

As a result, PEC I adopted a set of budgetary measures (known as austerity measures) in order to reduce the General Government deficit to 8.3\% of GDP in 2010 and achieve by 2013 a public deficit of $-2.8 \%$ of GDP (European Commission, 2010a, p. 13). Such measures were intended to reduce public expenditures to $49 \%$ of GDP (2010-2013). As Table 22 shows, the general government spending in 2009 was $50.223 \%$ of GDP (OECD, 2018u). 
Table 22 - Portugal's General Government Spending as a \% of GDP (2009-2015)

\begin{tabular}{ccccccc}
\hline $\mathbf{2 0 0 9}$ & $\mathbf{2 0 1 0}$ & $\mathbf{2 0 1 1}$ & $\mathbf{2 0 1 2}$ & $\mathbf{2 0 1 3}$ & $\mathbf{2 0 1 4}$ & $\mathbf{2 0 1 5}$ \\
\hline 50.223 & 51.819 & 50.016 & 48.527 & 49.940 & 51.767 & 48.201 \\
\hline
\end{tabular}

Source: OECD, 2018, General government spending (indicator). doi: 10.1787/a31cbf4d-en (Accessed on June 5, 2018)

Thus, the reduction of public expenditure proposed in PEC I considered several austerity measures to reduce social expenditure. The main measures are described in Table 23 (European Commission, 2010a, p. 15). The retrenchment measures detailed on Table 23 consist in a series of cuts, changes on eligibility and restrictions on the duration and generosity of the programs that were introduced to control public expenditure on several social citizenship programs and services, particularly cash benefits of all social assistance programs and on unemployment insurance. The reforms of the public health care system and public pension scheme that were initiated in 2007 have also been speeded up.

\section{Table 23 - Stability Programme 2010-2013 (PEC I): Main Retrenchment Measures on Social Expenditure}

1 Mandatory means-testing for all non-contributory social benefits

2 Nominal freezing of almost all non-contributory social benefits

3 Cuts in expenditures on non-contributory social benefits through a transfer cap

4 Restrictions and changes in the unemployment insurance program

5 Management and control of the expenditure on health services

6 Speeding up of the convergence of public pension systems

Source: European Commission (2010, p. 15), Portugal's stability and growth program (2010-2013). 
It is important to detail more those retrenchment measures. Firstly, the means-testing was proposed to become mandatory to all social assistance benefits in Portugal, in order to narrow the eligibility criteria to access such benefits. Income (reported in the income taxes) and assets were introduced as the two main criteria to determine the eligibility and accessibility to several social assistance benefits in order to support only those most in need. Secondly, almost all noncontributory social benefits were frozen in nominal terms and a cap was placed on transfers from the State Budget to all social assistance benefits - $€ 7100$ million in 2011, €7000 million in 2012 and $€ 6900$ million in 2013. For example, the cap for the GMI (RSI) was set to a maximum of $€ 400$ million in 2011 and $€ 370$ million in 2012 and in 2013 (European Commission, 2010a, p. 15). According to the program update (PEC I), those caps would allow for control of social expenditures by stabilizing and maintaining a sustainable share in GDP to stabilize public accounts (European Commission, 2010a, p. 18). The transfer caps (also known as ceilings) were supported by several additional control mechanisms to determine the eligibility and compliance to the rules of the program. Some of the mechanisms were: (1) increasing home monitoring of all GMI (RSI) beneficiaries; (2) income screening and mandatory validation of all benefits twice a year; (3) penalizations over fraud originated by the duty to disclose (income) and consequently overpayments made; (4) improvement of tax-surveillance databases to assess income and assets; and (5) work activation and employability measures through vocational training and employment support (job search and work enforcement) (European Commission, 2010a, p. 19). Thirdly, restrictions and changes to the unemployment insurance program were proposed through the revision of the rate for calculating the unemployment benefits based on the last insurable earnings; and reduction of the minimum wage threshold at which job acceptance is compulsory. Fourthly, the control of expenditure on the public health system over the period of 2010-2013 comprised 
several measures to reinforce the reforms and budgetary consolidation initiated in 2005 . From a service user perspective, one of the most punitive measures may have been the "[r]ationalisation of expenditure on medicines, medical material and supplementary diagnostic and therapeutic services" (European Commission, 2010a, p. 22). This measure included several "Medicines Policies" to curb the expenditure on outpatient medicines by $1 \%$ through the prescription of generic drugs. While in hospital care, the expenditure cuts were made on expensive drugs, i.e. HIV, Oncology and Rheumatology, and through the introduction of electronic prescriptions. Another important policy was the revision of state co-payments for seniors' medication. The expenditure for diagnostic and therapeutic services was also reduced by revising the billing rates of the diagnostic and therapeutic services provided (European Commission, 2010a, p. 24-25). Finally, the acceleration of the merging of the two public pension categories (one for civil servants (CGA) and a general one for all other workers) has been proposed through a new policy to penalize early retirements. The new policy also set a new legal retirement age to 65 through a new sustainability factor. Other measures proposed were the indexation of the public pensions to the consumer price index (inflation rate); and a faster transition to the new pension calculation formula which takes into account the entire career of premiums paid (European Commission, 2010a, p. 21).

Following the late submission and approval of PEC I (Stability Programme 2010-2013) on March 29, 2010, the European Commission issued a recommendation on April 14 to a Council's opinion on Portugal's budgetary strategy and policies defined by the Portuguese authorities in the update to the Stability Programme 2010-2013 (European Commission, 2010a, 2010b). Such recommendations were made under the preventive and corrective arms of the SGP (Eur-Lex, 1997c, 1997d, 2005a, 2005b). They took into account the "excessive deficit procedure" placed on 
Portugal by the ECOFIN Council on December 2, 2009. The "excessive deficit procedure" was initially defined by the corrective arms of the SGP (Council Regulations No. 1467/97 and No. 1056/2005) in accordance with Article 126 of the TFEU and by Protocol No. 12 of the Treaty which defines the reference values: a maximum annual budget deficit of $3 \%$ of GDP; and a maximum of national debt of $60 \%$ of GDP (Eur-Lex, 1997d, 2005b, 2008b, 2008c, 2008d). In 2009 Portugal's government deficit was $-9.81 \%$ (Table 12) and government public debt $96.1 \%$ (Table 13) (OECD, 2018j, 20181). Thus, the ECOFIN Council requested that Portugal's excessive deficit be corrected by 2013. According to the European Commission's recommendation for a Council's opinion, it was recommended that Portugal "bring the general government deficit below $-3 \%$ of GDP in a credible and sustainable manner by taking action in a medium-term framework" (European Commission, 2010b, p. 4). Several measures were proposed to achieve the correction of the fiscal deficit by 2013 (around 11/4\% of GDP over the 2010-2013 period). However, the ECOFIN Council established the deadline of June 2, 2010, for Portugal to adopt concrete actions to correct the excessive deficit (European Commission, 2010b, p. 4). The target defined of a $-8.3 \%$ GDP general government deficit in 2010 was in line with the consolidation measures defined by the 2010 State Budget (Law No. 3-B/2010 of April 28) (DRE, 2010). The budgetary consolidation on social transfers for 2010 should have represented a reduction in 1\% of GDP (European Commission, 2010a, 2010b).

On April 26, 2010, the ECOFIN Council issued its opinion and assessment on Portugal's budgetary consolidation measures outlined in the Stability Programme 2010-2013 (Eur-Lex, 2010b; European Commission, 2010a). The Council acknowledged that the budgetary consolidation being proposed in the Stability Programme 2010-2013 followed the recommendations made by the Council in December 2009 when the "excessive deficit procedure" 
was placed on Portugal. However, the Council stated that, in order to achieve the proposed budgetary strategy intended to achieve the reduction of the public deficit and debt, additional measures were required. The Council proposed a deficit target of $-8.3 \%$ of GDP for 2011 in order to achieve a deficit below $-3 \%$ of GDP by 2013.

The austerity measures announced in March 2010 through the approval of PEC I (Stability Programme 2010-2013) introduced harsh spending cuts to reduce the budget deficit to below $-3 \%$ GDP by 2013. Despite the budgetary discipline adopted with the measures announced in March 2010, the bonds of Portugal's public debt began to rise by April which led to uncertainty and even more financial instability as a result of the rise of the short-term interest rates, as shown in Illustration 2.

\section{Illustration 2 - The Rise of Portugal's Short-Term Interest Rates in 2010}

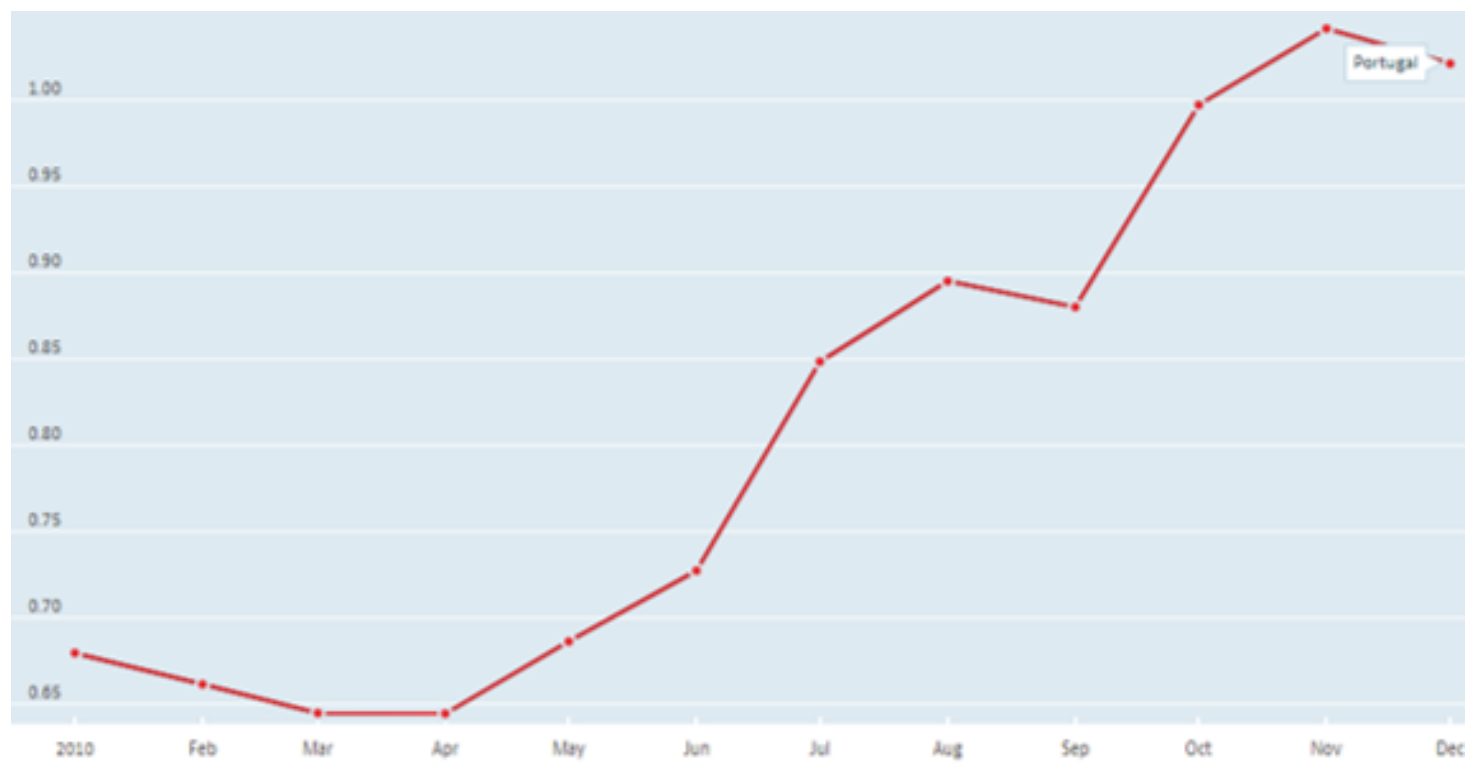

Source: OECD, 2018, Portugal's short-term interest rates, Jan-Dec 2010. 


\section{PEC II and III, and the 2011 state budget}

As a result of the sharp increase of interest rates paid by Portugal to borrow money on financial markets and of the concerns about the ongoing rise of public debt, the Portuguese government was forced to adopt further additional measures and more ambitious targets than the ones introduced by PEC I in March 2010 (European Commission, 2010a). Thus, on May 2010, the Portuguese Socialist government announced a new package of austerity measures known as PEC II (DRE, 2010b). The initial projected target for a public deficit of $-8.3 \%$ of GDP in 2010 became outdated. The new deficit targets defined by PEC II were $-7.3 \%$ of GDP in $2010,-4.6 \%$ of GDP for 2011, -3\% of GDP for 2012 and -2\% of GDP for 2013 (DRE, 2010b). The measures outlined in PEC II affected both the revenue and expenditure side and included: (1) the increase of all VAT (value-added tax rates) in $1 \%$ to $6 \%, 13 \%$ and $21 \%$; (2) an increase of $1 \%$ of the personal income taxes in the first three income brackets and $1.5 \%$ in the third and fourth income brackets; (3) an increase of corporate income taxes; (4) a reduction of transfers to all state-owned companies; (5) a 5\% cut in the salaries of all political jobs holders and government managers; and (6) restrictions on the hiring of civil servants (DRE, 2010b).

In September 2010, the Portuguese government announced an additional package of austerity measures, known as PEC III, ahead of the discussion and approval of the State Budget for 2011 (DRE, 2010c, 2010d). Such measures were aimed at meeting the deficit-reduction targets previously defined in March (PEC I) and May (PEC II) 2010 as well as to confirm that Portugal was not seeking an emergency bailout-loan from the EC and IMF. As shown in Illustration 2, in September 2010, the costs of borrowing rose to record levels which were severely undermining the consolidation of public finances and the reduction of the public deficit as initially planned. The main austerity measures introduced by PEC III in September 29, 2010 were: (1) cuts in all salaries 
of civil servants earning more than $€ 1,500$ a month (ranging from 3.5 to $10 \%$ ); (2) freezing of promotions and new admissions of civil servants; (3) reduction of allowances, overtime and accumulated wages, in particular the accumulation of public salaries with pensions; (4) freezing of all public pensions in 2011; (5) a 20\% cut of the expenditure with the GMI (RSI) program; (6) cancellation of the $25 \%$ top up in the first two brackets of child benefits and elimination of the child benefits for the fourth and fifth brackets; (7) reduction of the expenditure in the public health insurance system for civil servants; and (8) an increase of $2 \%$ to $23 \%$ on the VAT (DRE, 2010c).

Following the measures announced and introduced by PEC III in September 2010, the Portuguese government passed the harshest austerity cuts to be adopted by the 2011 State budget under the pressure of the Eurozone debt crisis (caused by the bailout of Greece and Ireland) in November 2010 (DRE, 2010d). The costs of borrowing rose sharply over the summer of 2010 and the interest paid to investors in order to borrow money, and in part to service existing debt, became unsustainable. Thus, the State Budget for 2011 included all the measures proposed on PEC III in September 2011 while it reinforced the budgetary cuts with further measures (DRE, 2010d).

Like the trend of the short-term interest rates paid by Portugal in the financial markets during 2010 which represents the government bonds usually maturing in three months (Illustration 2), Portugal's long-term interest rates for government bonds maturing in ten years also rose significantly as shown in Illustration 3, particularly between August and November. 


\section{Illustration 3 - The Rise of Portugal's Long-Term Interest Rates in 2010}

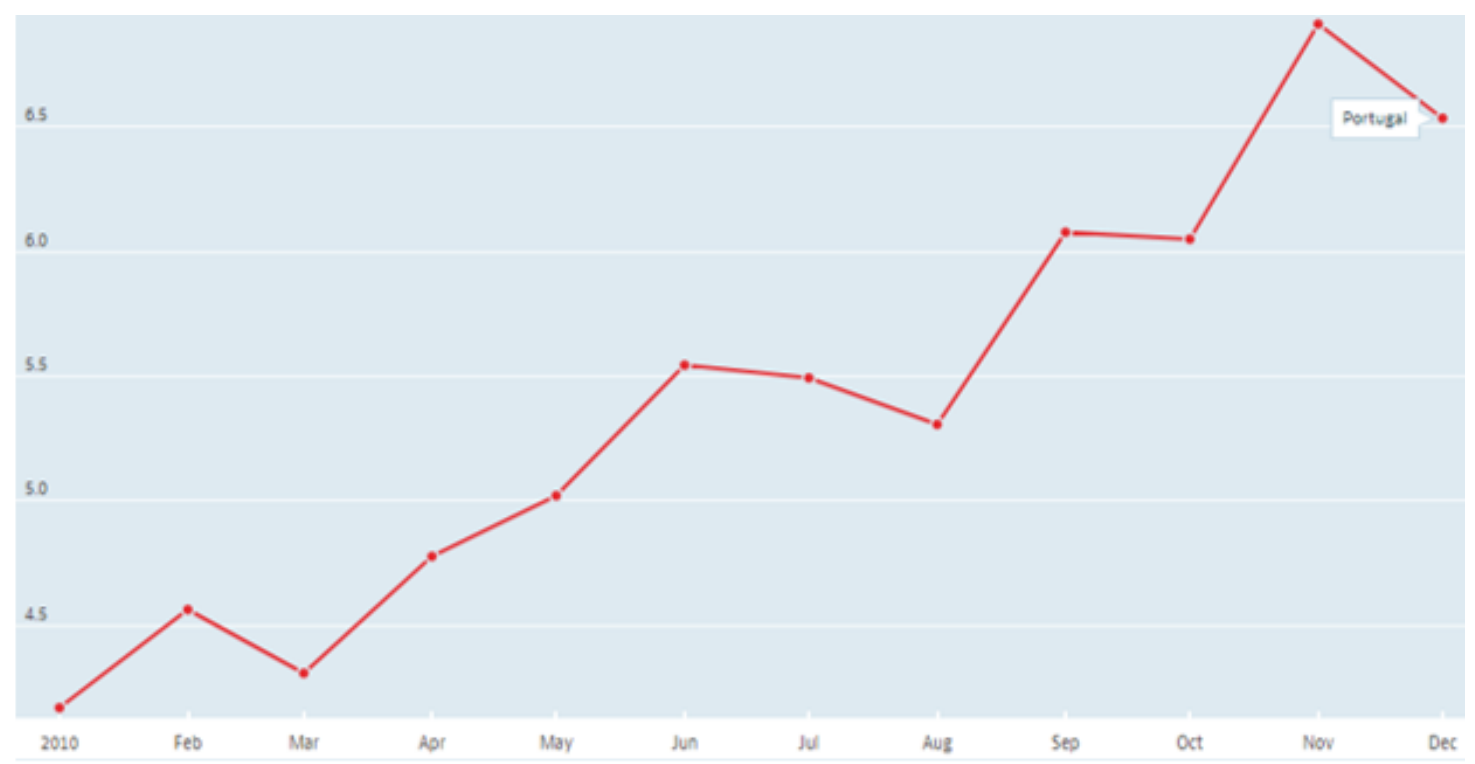

Source: OECD, 2018, Portugal's long-term interest rates (indicator), Jan-Dec 2010.

The macroeconomic and fiscal scenario described above may explain the harsh budgetary consolidation undertaken by Portugal during 2010. The European debt crisis and the financial instability caused by the bailouts to Greece (in May) and Ireland (in November) 2010 have directly influenced the pressure from the financial markets and from the EU on Portugal to seek financial assistance.

Therefore, the scale of budgetary consolidation undertaken in PEC I (March 2010), PEC II (May 2010) and PEC III (September 2010) as well as the measures proposed in the 2011 State budget were justified by the Portuguese government with the aim of curbing the public deficit and debt. In 2010, the official public deficit ended up in $-11.17 \%$ of GDP (Table 12) while the public debt was at $104.1 \%$ of GDP (Table 13). 
Table 24 - Portugal's Short-Term Interest Rates - \% per annum (2009-2015)

\begin{tabular}{lllllll}
\hline $\mathbf{2 0 0 9}$ & $\mathbf{2 0 1 0}$ & $\mathbf{2 0 1 1}$ & $\mathbf{2 0 1 2}$ & $\mathbf{2 0 1 3}$ & $\mathbf{2 0 1 4}$ & $\mathbf{2 0 1 5}$ \\
\hline 1.23 & 0.81 & 1.39 & 0.57 & 0.22 & 0.21 & -0.02 \\
\hline
\end{tabular}

Source: OECD, 2018, Portugal's short-term interest rates (indicator). doi: 10.1787/2cc37d77-en (Accessed on June 5, 2018)

Despite the higher public deficit and the rise of the public debt throughout 2010, the effects of the Eurozone crisis were felt directly in the rise of interest rates on Portuguese debt. Table 24 and 25 shows that, while the overall short-term interest rates did decrease when compared with 2009, the long-term interest rates increased when compared with 2009. Illustrations 2 and 3 clearly describe the scale and the evolution of the impact of the rise of interest rates in 2010.

\begin{tabular}{|c|c|c|c|c|c|c|}
\hline \multicolumn{7}{|c|}{ Table 25 - Portugal's Long-Term Interest Rates - \% per annum (2009-2015) } \\
\hline 2009 & 2010 & 2011 & 2012 & 2013 & 2014 & 2015 \\
\hline 4.2 & 5.4 & 10.2 & 10.5 & 6.3 & 3.8 & 2.4 \\
\hline
\end{tabular}

Source: OECD, 2018, Portugal's long-term interest rates (indicator). doi: 10.1787/662d712c-en (Accessed on June 5, 2018)

Turning to the "European Semester" in order to introduce and analyze Portugal's 2011 economic and fiscal coordination policies, the European Semester framework has been introduced in 2010 to coordinate the economic and fiscal policies of all EU member states throughout the year and in order to ensure compliance with sound public finances, prevent fiscal imbalances and plan and execute structural reforms in line with the European Commission policy orientations and the recommendations set by the ECOFIN Council (Eur-Lex, 2010c). The "European Semester" is a 
clear annual cycle of economic and fiscal policy coordination, starting in November of each year and finishing in the October of the following year when EU Member States submit their draft budgets which are in line with the recommendations made by the ECOFIN Council over the summer (Eur-Lex, 2010c). One of the main changes introduced by the European Semester coordination framework, which started its first cycle in 2011, was the need for all member state submit an annual National Reform Program, a document that outlines a structural reform plan that should be aligned with the "Europe 2020" strategy which contains targets in core policy areas. Eurozone member states continued to submit their annual Stability Programme (3-year budget plan). Basically, the rules of the Stability and Growth Pact strengthened by the "Six-Pack", "TwoPack", and by the Treaty on Stability, Coordination and Governance in the Economic and Monetary Union (TSCG), that were introduced earlier in this chapter, are being applied through the "European Semester" framework (Eur-Lex, 2010c).

\section{PEC IV (Stability Programme 2011-2014)}

In early 2011, borrowing costs became unsustainable. The alarms soared, with Portugal lurching towards a "debt explosion" with long-term interest rates on the rise $(7.1 \%$ in January 2011). Thus, the Stability Programme 2011-2014, also known in Portugal as PEC IV was discussed and voted in the Portuguese parliament (Assembleia da República) in late March. Due to the circumstances being described, the Portuguese Socialist government proposed another package of harsh austerity measures in PEC IV (Stability Programme 2011-2014) (GovPT, 2011a). In addition, the National Reform Program (NRP) "Portugal 2020” was also approved in March 2011 by the Portuguese government and submitted to the European Commission, as part of the 
requirements of the "European Semester" economic and fiscal coordination policies (Eur-Lex, 2010c; European Commission, 2011c).

In association with the Stability Programme 2011-2014 (PEC IV), the NRP "Portugal 2020 " proposed several structural reforms in line with the "Europe 2020" strategy, a reference framework that defines several EU targets (European Commission, 2018a). Portugal's NRP took into consideration the macro-economic scenario for the period 2011-2014 and has followed the ongoing budgetary consolidation being adopted by the Portuguese government since 2010 . The NRP “Portugal 2020' strategy defined a $-4.6 \%$ of GDP for 2011 , a $-3 \%$ of GDP in 2012 and a $-2 \%$ for 2013 as the targets for the reduction of public deficit. It also established a commitment to achieve a 75\% employment rate (aged 20-64 years old) by 2020 (European Commission, 2018a). Regarding the economic and financial situation, the view of the Portuguese government laid out in the NRP is that, "the [2008 financial] crisis and the actions taken to counter its effects led to a high level of public debt in 2009" (European Commission, 2018a, p. 12). Moreover, the NRP also affirms the "good situation in terms of the sustainability of public finances" is a result of the reforms adopted in the public social security system (European Commission 2018a, p. 12). Some of the so-called "structural reforms" being outlined in the program started being implemented between 2005-2007, such as the convergence of the social security systems; the employer's contribution to the general public pension system. The need to improve flexibility and adaptability in the labour market is also defined as a key priority, among several other reforms in the labour market (European Commission, 2018a, p. 15). In terms of promoting employability for what the NRP calls "disadvantage groups", the Portuguese government proposed the creation of what they call "Employment-Insertion Contracts" (Contratos Emprego-Inserção also known as CEI) for people on unemployment insurance and GMI program (RSI). This measure has been described to 
cover around 50,000 people on unemployment insurance and 12,000 on RSI (European Commission, 2018a, p. 60). Other measures are also announced for seniors and families, such as an increase in the amounts of the allowances for single-parents and for seniors (CSI) (European Commission, 2018a, p. 61).

The Stability Programme 2011-2014 (known as PEC IV) was only prepared, in March 2011, by the Portuguese government, in the context of severe constraints due to the rise of longterm interest rates in 2010 and in the beginning of 2011 (Table 25) (GovPT, 2011a). Portugal ended 2010 with a government public deficit of $-11.17 \%$ of GDP (Table 12) and a public debt of 104.1\% of GDP (Table 13). Thus, the Stability Programme 2011-2014 (PEC IV) proposed harsh and more restrictive austerity measures which included further tax hikes, cuts to social spending, further cuts in the salaries of public servants among several other measures (GovPT, 2011a). It is stated in PEC IV's executive summary that the target of the measures being proposed in the program aim to reduce the public deficit to $-4.6 \%$ of GDP in 2011, -3\% of GDP in 2012 and $-2 \%$ of GDP in 2013 (GovPT, 2011a, p. V). The government also reinforced its commitment with the fiscal consolidation measures proposed in May 2010 (PEC II) while deepening them through a severe budgetary consolidation intended to reduce the public deficit by 5.3\% of GDP in 2011 (GovPT, 2011a). In addition to the budgetary consolidation already defined in the State Budget for 2011, the Portuguese government decided to deepen the ongoing budgetary consolidation with additional measures worth in $0.8 \%$ of GDP with key areas like public health care and social protection (DRE, 2010d, 2011).

A wide range of measures were proposed in PEC IV. The government states that such measures represent "the biggest budgetary consolidation effort already adopted in Portugal" and also the biggest budgetary consolidation proposed in the EU in 2011 (GovPT, 2011a, p. 11). The 
additional measures proposed by PEC IV for 2011 represented an impact of $0.05 \%$ on health care and of $0.1 \%$ on social protection (GovPT, 2011a, p. 11). With regards to health care, the additional measures include, for example, an agreement with the pharmaceutical industry to establish a ceiling mechanism for drug expenditure to limit the cost of public expenditure with medication, aiming to reduce the expenditure by $21 \%$ in two years, which represented an additional cut in the total amount of $€ 80$ millions in addition to what had been considered in the State Budget for 2011 (DRE, 2010d, 2011a). The measures on social protection proposed in PEC IV also included "savings" (cuts) on expenditure through the improvement of fraud control and tight review of the eligibility criteria of the means-testing related information (Condição de Recursos) (GovPT, 2011a). The measures proposed for 2012 and 2013 were to pursue the same tight budgetary consolidation to meet the deficits of $-3 \%$ GDP in 2012 and -2\% GDP in 2013. They include cuts in pensions, public health care and the review of the eligibility criteria of all cash benefits of social protection (GovPT, 2011a).

Despite Portugal's macroeconomic scenario and fiscal problems, the fourth package of austerity measures in eleven months was rejected, on March 23, by the Portuguese Parliament (Assembleia da República), and this pushed the country to an emergency international bailout from the European Commission, the ECB and the IMF (Troika), following the bailouts to Greece and Ireland in 2010.

Following the rejection of the Stability Programme 2011-2014 on March 23, Moody's, one of three most important rating agencies, downgraded, in early April Portugal's sovereign bonds to junk status ("Ba1", one level below investment grade). Standard \& Poor's and Fitch did the same. Only the Canadian credit rating agency DBRS raised, in early April the status of Portugal's sovereign bonds from "BBB low", its lowest investment grade ranking, to "BBB", its second 
lowest, while maintaining a stable outlook. Consequently, Portugal formally requested international financial assistance to the European Financial Stability Facility (EFSF), the EU and IMF on April 7 (European Commission, 2011a, 2011d). The EFSF was one of the two mechanisms created in May 2010 by the EU as a temporary crisis mechanism to provide financial support to EU member states. The other mechanism was the European Financial Stabilisation Mechanism (EFSM) also established in May 2010 (Eur-Lex, 2010d, 2010e). The first member state to receive financial support from the EFSF was Ireland in February 2011 followed by Portugal in June 2011 and Greece in March 2012. The EFSF was replaced in 2012 by the European Stability Mechanism (ESM) in October 2012.

Following Portugal's formal request for an emergency loan, the Eurogroup and ECOFIN Council invited the European Commission, the ECB, the IMF and Portugal to set up a bailout program to be "financed on the European side within the framework provided by the European Financial Stabilisation Mechanism (EFSM) and the European Financial Stability Facility (EFSF)" (Eur-Lex, 2010e, p. 1). The statement released by the Eurogroup and ECOFIN Council also stated that, the bailout program will be based on "ambitious fiscal adjustment to restore fiscal sustainability" which would take in consideration the measures that had been proposed by the Stability Programme 2011-2014 (PEC IV) (Eur-Lex, 2010e, p. 1).

Similar to the previous submissions of the annual update to the Stability Programme, the EC offered a recommendation to an ECOFIN Council opinion on the 3-year budgetary plan proposed in the Stability Programme. As mentioned before, under the "European Semester" framework, since 2011 member states are also required to submit a National Reform Program. Thus, the European Commission and the ECOFIN Council recommended that Portugal should implement the measures laid down in the MoU with the Troika (Eur-Lex, 2011h, 2011i). 


\section{Portugal's bailout program (2011-2014)}

On May 13 and 17, 2011, following the preparatory negotiations with the three international bodies commonly designated as the Troika (European Commission, ECB and IMF), the Portuguese government, which had stepped down when PEC IV was rejected on March 23, formally agreed to a "far-reaching reform programme" by issuing letters of intent (acceptance) to the EU authorities (ECOFIN Council, European Commission and ECB) and to the IMF (GovPT, 2011a; IMF, 2011a). The letter of intent (acceptance) sent to both international bodies formally requested and agreed with an external bailout-program of around $€ 78$ billion euros over three years (€52 billion euros from the European Financial Stabilisation Mechanism (EFSM) and the European Financial Stability Facility (EFSF) and $€ 26$ billion euros from the IMF) (GovPT, 2011a; IMF, 2011a). In order to benefit from the bailout program, the Portuguese government agreed to implement several structural reforms and deep fiscal measures (commonly known as austerity measures) (GovPT, 2011b, 2011; IMF, 2011a). Consequently, the EU Council approved Portugal's bailout-program on May 17, 2011 and the IMF on May 20, 2011 (European Council, 2011; IMF, 2011b). According to IMF's (2011b) press release, the bailout-program's focus was on enhancing structural reforms, and on restoring confidence and fiscal sustainability through a bold and ambitious agenda of fiscal consolidation to ensure debt sustainability, economy's competition and growth, employment and productivity. In other words, the MoU set a fiscal consolidation strategy through a mix of revenue-raising and expenditure-reducing measures. It also aimed to stabilize the financial sector, mainly strengthen the banks' liquidity and solvency; and it also carried out a comprehensive structural reform agenda in different areas of government responsibility (European Commission, 2011e). 
The MoU is a formal agreement between Portugal and the Troika (European Commission, ECB and IMF). In addition to the Letter of Intent, the MoU package is composed of three main policy documents: a Memorandum of Economic and Financial Policies, a Memorandum of Understanding on Specific Economic Policy Conditionality and a Technical Memorandum of Understanding (European Commission, 2011e; IMF, 2011b).

The MoU is therefore the main object of this dissertation research (European Commission, 2011e; IMF, 2011c). The primary sources are the Memorandum of Economic and Financial Policies and the Memorandum of Understanding on Specific Economic Policy Conditionality (European Commission, 2011e, p. 41, 58). The eleven quarterly reviews (updates) of the $\mathrm{MoU}$ (September 2011-April 2014) and the program conclusion (May 2014) are also analyzed.

The Memorandum of Economic and Financial Policies (MEFP) introduces Portugal's macroeconomic outlook in order to characterize the Portuguese economy and justify the proposed fiscal targets to reduce public debt and deficit. According to the MEFP, Portugal's public deficit was around $-10 \%$ of GDP at the end of 2010 while the public debt was at around $90 \%$ of GDP in the same period. The budgetary targets proposed by the MoU for 2011-2012 are a deficit of $-5.9 \%$ of GDP in 2011, -4.5\% of GDP in 2012 and a -3\% of GDP in 2013 (European Commission, 2011e; IMF, 2011b). Such deficit consolidation represents a cumulative fiscal effort of $10 \%$ of GDP between 2011-2013, respectively 5.7\% of GDP in $2011,3.0 \%$ of GDP in 2012 and $1.9 \%$ of GDP in 2013 (European Commission, 2011e, p. 18).

The budgetary consolidation for 2011 strictly followed the measures already defined in the 2011 State Budget and also the additional measures included in the Stability Programme 20112014 (PEC IV) (DRE, 2010d, 2011; European Commission, 2011e). It included measures on the expenditure and revenue side. For 2012-2013, the measures were mostly concentrated on the 
expenditure side. Structural reforms were also proposed with regards to the public health care system and the labour market (European Commission, 2011e; IMF, 2011b).

Thus, Table 26 outlines the scale of austerity measures on public expenditure with social citizenship rights proposed by the MoU through the MEFP for 2011-2013 (European Commission, 2011e, p. 41).

Table 26 - Main Austerity Measures on Public Expenditure with Social Citizenship Rights (Memorandum of Understanding - May 2011)

1 Public pensions frozen to 2013 (except the lower old-age pensions)

2 Penalization for public pensions above $€ 1,500$ in 2012 (except the lower old-age pensions)

3 Cuts and changes to cash benefits - unemployment insurance and family allowances

4 Revamp the means-testing procedures to protect lower-income families

5 Curriculum redesign and rationalization of the public school system

Source: European Commission (2011e, p. 42), The economic adjustment programme for Portugal.

On the revenue side, the MEFP introduced a series of measures that can affect more deeply those who rely on the welfare state, although such measures cannot be defined as social citizenship rights. The main measures that were proposed are: (1) a rise of the VAT rate of 2\% (already introduced by the 2011 State Budget); (2) revision of a list of goods and services subjected to a reduced VAT rate; (3) taxation of the hydro bill in 2012; (4) the revision or elimination of tax rebates for expenses on health care and education through new legislation being introduced in 2011; and (5) the revision of the co-payments in the public health care system to reduce or eliminate fees for the most vulnerable and to some selected groups or professions (European Commission, 2011e, p. 43). 
The MEFP also contained policy orientations for structural reform of the labour market. Measures included changes in job protection laws, particularly on unemployment insurance to: (1) place a limit on the maximum duration of the benefit to no more of 18 months; (2) introduce a cap on the maximum insurable earnings at 2.5 times the "social support index"; (3) reduce the premium rate (around 10\%) after the first the sixth month of benefits; (4) reduce the required insurable months period (from 15 to 12 months) to quality; and (5) extend eligibility to self-employed workers (European Commission, 2011e, p. 52).

Therefore, the proposed fiscal consolidation aimed to mitigate the public deficit and stabilize the debt by adopting measures on both the expenditure and the revenue side. Illustration 4 offers an overview of the composition and distribution of the impact of such measures on Portugal's fiscal's consolidation strategy (IMF, 2011c).

Illustration 4 - MoU's Fiscal Adjustment Measures for 2011-2013 (\% of GDP)

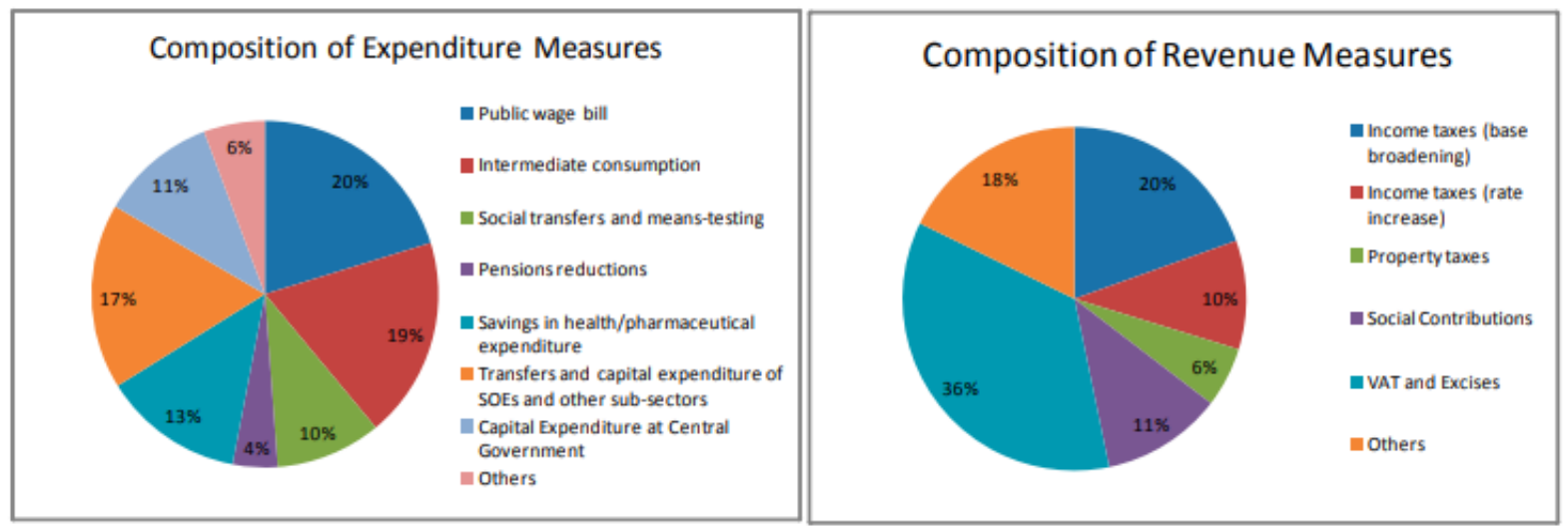

Source: IMF (2011c, p. 11), Portugal: request for a three-year arrangement under the extended fund facility (Country Report No. 11/127). 
Although the MoU details its consolidation program through the MEFP, the Memorandum on Specific Economic Policy Conditionality provided a more consistent and descriptive analysis of the measures being proposed by the MEFP. The scale of measures required by the MoU follows a detailed program and process, outlined under the terms of the agreement. Such measures and targets were to be strictly implemented, under the timeline and conditions outlined in order for Portugal to receive the financial assistance from the Troika.

The conditionality of the MoU was to be reviewed throughout the three-year duration of the program to assess the compliance with the measures and timeline defined by the Memorandum on Specific Economic Policy Conditionality in order to monitor the progress made between 2011 and 2014. The main targets of the Memorandum on Specific Economic Policy Conditionality are: fiscal policy; financial sector regulation and supervision; fiscal-structural measures; labour market and education; goods and service markets; housing market; and framework conditions (European Commission, 2011e, p. 59-93).

The bulk of the conditions to be met and assessed in the Memorandum on Specific Economic Policy Conditionality by this dissertation are the targets on fiscal policies, on fiscalstructural measures (particularly the "revenue administration" and health care system), and on labour market and education.

The dimension "fiscal policy" aimed to reduce Portugal's government deficit to "EUR 10,068 million (equivalent to $5.9 \%$ of GDP based on current projections) in 2011, EUR 7,645 million (4.5\% of GDP) in 2012 and EUR 5,224 million (3.0\% of GDP) in 2013" (European Commission, 2011e, p. 59). These targets have determined the measures being outlined in the MEFP (Table 26 and Illustration 4) and in the Memorandum on Specific Economic Policy Conditionality to be adopted during the three-year duration of the program. For 2011, as mentioned 
before, the fiscal policies followed the measures defined by the State Budget Law for 2011 and by PEC IV (Stability Programme for 2011-2014) with the aim to obtain a deficit of no more than "EUR 10,068 million by the end of the fourth quarter [Q4-2011] (December 2011). In terms of public expenditure, for 2012, the cuts to social citizenship rights included cost controls (expenditure reduction) of "EUR 550 million" on the public health care system; savings of "EUR 445 million" obtained with the penalization placed on public pensions above $€ 1,500$ and the freezing of all pensions (except the lowest ones); while on unemployment insurance the cuts were estimated in "EUR 150 million" and on public education "EUR 195 million" (European Commission, 2011e, p. 60). On the revenue side, the Memorandum on Specific Economic Policy Conditionality also provided a detailed balance sheet of its fiscal policy. For 2012, the "savings" being proposed, either through cuts and elimination of tax-deductions, or through the taxation of all cash benefits would represent at least "EUR 150 million" (European Commission, 2011e, p. 61-62). For 2013, the proposed measures will amount of "EUR 5,224 million" on both expenditure and revenue sides, in which "EUR 175 million" would represent cuts in expenditures in the public education system; "EUR 375 million" on the expenditure in the public health system; and around "EUR 350 million" in savings through the changes introduced with the means-testing on all social benefits (European Commission, 2011e, p. 62-63). On the revenue side, "EUR 150 million" would be obtained through the taxation of all cash benefits and the convergence of the taxation on pensions and labour income" (European Commission, 2011e, p. 63).

The "fiscal-structural measures" dimension, particularly the budgetary control of the public health system deserves closer attention. While the Portuguese government committed itself to adopting deep cuts in its public health care system (SNS), its financing would be obtained by increasing the SNS co-payment fees either through the revision of the category exemptions by 
applying strict means-testing rules or by increasing the fees to access certain services and medical sub specialties. The savings on public health care also included cuts (by two thirds) in tax allowances to access health care services, including access to private practice. Other measures related to drug expenditures were proposed, on both pricing and reimbursement, in order to finance generic drugs and bring down expenditures on brand medication (European Commission, 2011e, p. 74).

The "labour market" dimension, particularly the labour market policies related to unemployment protection, translated the structural reforms to be adopted on unemployment insurance through the revision of legislation to reduce or even "eliminate" the protection on longterm unemployment, promote flexibility and enhance competitiveness in the labour market (European Commission, 2011e, p. 78). Changes on unemployment insurance have already been explored above, during the analysis of the MEFP. Thus, the Memorandum on Specific Economic Policy Conditionality established at the end of 2011 to adopt these changes [Q4-2011].

This MoU set an initial but very consistent ground to understand the package of austerity measures (also known as budgetary consolidation) set and agreed between Portugal and the Troika. It laid down a comprehensive adjustment and reform program with policy objectives and steps necessary to obtain the issuance of the tranches from the EU mechanisms and from the IMF. The fact that the policy analysis is being done from the Troika's perspective, complemented by the policy responses set by the Portuguese authorities, is a testament to the nature and scope of the fiscal consolidation process put in place, and consequently, its impact on social citizenship rights. Following the analysis of key dimensions that are directly or indirectly related social citizenship rights, either through cuts on social spending, changes in the eligibility, withdrawal from public provision or by introducing restrictions in those programs and services, the analysis of the quarterly 
reviews (updates) made to the MoU provides a detailed scope of the austerity measures adopted in Portugal during the length of the bailout program (2011-2014).

The first quarterly review (update) of the MoU took place in August 2011 (European Commission, 2011f; IMF, 2011d). The review was made by a joint-mission of the European Commission, the ECB and the IMF between August 1 and 12, 2011, to assess compliance with the conditions set in the MoU. In a joint press release on August 12, the European Commission, the ECB and the IMF affirmed that the "program is on track" (European Commission, 2011g; IMF, 2011e). Thus, the European Commission and IMF's reports concerning the first MoU quarterly review were published in September 2011. They will be analyzed in order to obtain evidence of the findings of the Troika's first assessment while contributing also to determining if additional fiscal measures were proposed or adopted. The European Commission and the IMF's reports also included Portugal's comments on the MoU's first review while offering, eventually, commitments for additional measures (European Commission, 2011f; IMF, 2011d).

The Troika's first quarterly review took place following the election of the new Portuguese government on June 5, 2011, a coalition composed by two right-wing political parties - Socialdemocrats (PSD) and Christian-democrats (CDS). The MoU, the MEFP and the Memorandum on Specific Economic Policy Conditionality were updated to reflect new economic and policy developments as a result of new developments occurring at the political, fiscal and economic levels since the signature of the MoU in May 2011.

Although the Troika had recognized that the MoU's program implementation "were on track" at the time of its visit (August 1-12, 2011), it highlighted that, budgetary consolidation measures "have not delivered the full expected impact and there have been substantial unexpected one-offs operations. The budget deficit for the year as a whole risked exceeding the programme 
target on a national account basis but corrective actions are being taken" (European Commission, 2011f, p. 15).

In response, Portuguese authorities adopted new actions and proposed new measures. The reduction of public deficit and debt (as a percentage of GDP) remained as proposed: $-5.9 \%$ in $2011,-4.5 \%$ in 2012 , and $-3 \%$ in 2013 , while the government recognized that "pressures have emerged" (European Commission, 2011f, p. 46). New additional measures were proposed, either in the update to the MEFP or in the update to the Memorandum on Specific Economic Policy Conditionality. The first update to the MEFP outlined several additional measures, in particular, a special surcharge on personal income taxes (with an impact of $0.5 \%$ of GDP in 2011 and $0.1 \%$ of GDP in 2012). The reduced VAT rates on utilities like house gas and hydro were proposed to be increased to the standard rate (starting on October 1, 2011). While in the labour market, new legislation was introduced on severance pay for new employment contracts reducing the lumpsum payment benefits to 20 days per year of service while eliminating all benefits during the first three months of contracts. The new legislation was planned to enter into force by the end of September 2011 (European Commission, 2011f, p. 52). The Memorandum on Specific Economic Policy Conditionality was also updated. The new Portuguese government reinforced its budgetary consolidation towards social citizenship rights, on both expenditure and revenue sides (Table 27). In is also important to highlight that, the taxation of all cash benefits of social citizenship rights for 2012 was reinforced. 
Table 27 - Main Austerity Measures for 2012 on Public Expenditure with Social Citizenship Rights (First Update - September 2011)

1 Freeze salaries on public sector

2 Reduction of public pension expenditure in gross terms by at least $€ 445$ million

3 Cuts to unemployment insurance by at least $€ 150$ million

4 Savings in public health care system worth in $€ 550$ million

5 Cuts to public education worth in $€ 195$ million

Source: European Commission (2011f, p. 67-68), The economic adjustment programme for Portugal: first review.

Table 27 outlines the main key measures for 2012 that impact directly or indirectly social citizenship rights, which were proposed or updated by the Portuguese authorities in the first MoU's update, following the Troika's first assessment. Expenditures on pensions were reduced through limits on those above $€ 1500$, through the suspension of the annual indexation rules and the freezing of all pensions, except the lowest ones. The cuts proposed on unemployment insurance were part of a broader structural reform carried under the MoU signed in May 2011 aiming to revise the legislation of unemployment insurance protection. With regards to the public health care and education systems, the measures being proposed were intended to reinforce the ones initially included in the MoU (European Commission, 2011f, p. 67-68). On the revenue side, it is important to highlight the taxation of all types of cash benefits (European Commission, 2011f, p. 69).

The second quarterly review (update) of the MoU took place in November 2011 (European Commission, 2011h; IMF, 2011f). The Troika's (European Commission, ECB and IMF) mission visited Portugal between November 7-16, 2011 to assess Portugal's economic and financial policies in order to determine compliance with the objectives and targets set in the MoU signed in May 2011 between Portugal and the European Commission, the ECB and the IMF (European 
Commission, 2011e; IMF, 2011c). In a joint-statement released on November 16, 2011, the European Commission, the ECB and IMF stated that an agreement had been reached regarding the necessary economic and financial policies to achieve the objectives set out in the MoU (European Commission, 2011i; IMF, 2011g). The joint-statement also praised the "bold and welcome measures" proposed by the Portuguese government in the state budget 2012 (DRE, 2011a; European Commission, 2011i; IMF, 2011g). The fiscal target of 4.5\% of GDP for 2012 had been defined as very ambitious. However, the Troika recognized the quality and effectiveness of the additional measures being proposed such as nominal cuts to wages of public servants and on public pensions (European Commission, 2011i; IMF, 2011g).

The second quarterly review (update) of the MoU took into account the economic forecast for 2012. The predictions initially made in May 2011 were too optimistic and ambitious. In addition, the budgetary execution during 2011 did not met the targets proposed. The new risks and the predicted economic downturn for 2012 were used by the Portuguese government and the Troika to propose new additional measures (European Commission, 2011h; IMF, 2011f).

In its Letter of Intent sent to the EU authorities on December 9, 2011, the Portuguese government stated that "policy implementation is broadly on track" (European Commission, 2011 h, p. 60). However, the government pointed out to the "bold and comprehensive 2012 budget" that was approved to put "public finances on a sustainable path and bolster market confidence" with the progress of the bailout program (European Commission, 2011h, p. 60).

The MEFP update to the second MoU quarterly review outlined an updated macroeconomic outlook for 2012. It predicted that, "the economy is expected to contract by 1.6 percent for the year as a whole. In 2012, with more limited support from exports and a larger fiscal adjustment than at the time of the program, activity is projected to fall by 3 percent" (European 
Commission, 2011h, p. 62). Further, it was recognized that the 3.2\% of projected inflation for 2012 results from the fiscal consolidation effort (European Commission, 2011h). Thus, the MEFP argued that the lack of expenditure control and a shortfall on some projected additional revenues created a gap of $1.6 \%$ into GDP forcing $1.3 \%$ to be carried over to 2012 . Consequently, for 2012 , the proposed government deficit was $4.5 \%$ GDP with two thirds of the cuts being on the expenditure side. The key fiscal measures being proposed, which are in line with the state budget for 2012, were the following: (1) suspension of the thirteenth and fourteenth-month bonus salary and pensions; and (2) reduction of goods and services subjected to a reduced VAT rate (European Commission, 2011h, p. 62). In the public health care system, following the measures set initially in the MoU, cuts were being already adopted on pharma care and on hospital operating costs. The rise of co-payment fees (taxas moderadoras) and the reduction of exceptions is set to be in place by the end of January 2012 (European Commission, 2011h, p. 65). These measures were further explored in the second update to the Memorandum on Specific Economic Policy Conditionality (European Commission, 2011h, p. 86). They represented an impact of 5.3\% GDP and followed strictly the law of the State Budget for 2012 (DRE, 2011a). Such measures are two thirds on the expenditure side and one third on the revenue side. The expenditure cuts directly related with public wages and social citizenship rights are outlined on Table 28.

Such measures (Table 28) represent the strict commitment with budgetary consolidation that aims to fix the 2011 budgetary slipperiness while offering a strong budgetary target and structural reform program. With regards to the public health system, the proposed measures for 2012 aimed to obtain savings of $€ 1000$ million through savings on the expenditure of public pharmacare and on hospital operating costs. On the topic of public education, the rationalization of the public school system and reduction of the public financing to private schools would 
represent savings of $€ 380$ million. While on cash benefits of social protection, the cuts of at least $€ 180$ million were made by changing the eligibility criteria and conditionality of different cash benefits of social citizenship rights (European Commission, 2011h, p. 86-88).

\section{Table 28 - Main Austerity Measures for 2012 on Public Expenditure with Social Citizenship Rights (Second Update - December 2011)}

1 Reduction of salaries on public sector by at least $€ 3000$ million

2 Reduction of public pension expenditure in gross terms by at least $€ 1260$ million

3 Savings in public health care system worth in $€ 1000$ million

4 Cuts to the public education worth in $€ 380$ million

5 Reduce cash benefits (other than pensions) by at least $€ 180$ million

Source: European Commission (2011h, p. 86-88), The economic adjustment programme for Portugal: second review.

For 2013, the fiscal policies outlined in the Memorandum on Specific Economic Policy Conditionality aimed to achieve a general government deficit of $-3 \%$ of GDP by the end of the 2013. On the expenditure side, social citizenship areas like public health care (€375 million), public education ( $€ 175$ million) and cash benefits ( $€ 250$ million) faced severe cuts. Public salaries and pensions continued to be frozen as well (European Commission, 2011h, p. 90-91).

Illustration 5 provides an account of the budgetary consolidation distribution being proposed per areas (as a \% of GDP) for 2012 and 2013. These fiscal measures translate the targets of the harsh budgetary consolidation and structural reforms agreed between the Troika and the Portuguese authorities as part of a joint financing package from the EU mechanisms and from IMF, worth €78 billion (European Commission, 2011h; IMF, 2011f). 


\section{Illustration 5 - MoU's Fiscal Adjustment Measures per area for 2012 - 2013 (\% of GDP)}

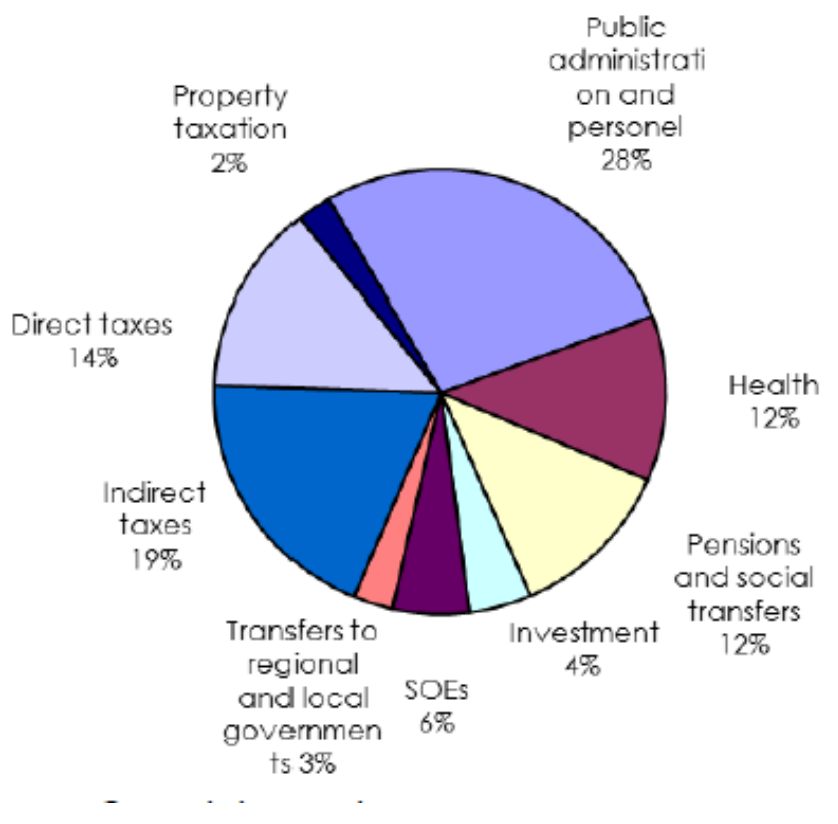

Source: European Commission (2011h, p. 22). The economic adjustment programme for Portugal: second review.

The third quarterly review (update) of the MoU took place in February 2012 (European Commission, 2012c; IMF, 2012a). A joint-mission composed by the European Commission, the ECB and IMF visited Portugal between February 15 and 27, 2012. In a joint press-release they affirmed that, "the programme is on track, but challenges remain" (European Commission, 2012d; IMF, 2012b). Moreover, the statement read: "the large fiscal correction in 2011 and the strong 2012 budget have bolstered the credibility of Portugal's front-loaded fiscal consolidation strategy" (European Commission, 2012d; IMF, 2012b). That said, from Troika's perspective, Portugal's fiscal and economic adjustment had produced effect on financial markets. Following this third- 
quarterly review, the initial deficit target of $4.5 \%$ for 2012 remained as initially planned (European Commission, 2012d; IMF, 2012b).

This third quarterly review took place in a context of a projected deep economic recession. The effort of the Portuguese government with the approval of further austerity measures in the State Budget for 2012 coupled with soaring unemployment rates (Table 14) and the depletion of public expenditure on social citizenship rights led to a snowball effect of economic and fiscal uncertainty for 2012. The unemployment rate in 2011 was $12.68 \%$ (Table 14) which consequently led to the rise of public spending on unemployment insurance (Table 18).

According to the EU's Third Review Report (European Commission, 2012c, p. 4), “[t]he Programme's 2011 target for the general government deficit of 5.9 per cent of GDP has been overachieved by resorting to a transfer of banks' pension funds to the state amounting to $3 \frac{1}{2}$ per cent of GDP." Despite the 4.5\% deficit target for 2012, which represented a deficit reduction of 4\% of GDP, the Portuguese government prepared, in March 2012 a supplementary additional budget for 2012. As mentioned before, the Troika's (European Commission, ECB and IMF) mission had assessed, between February 15 and 27, 2012, Portugal's compliance with the MoU's conditionality associated with the fourth loan disbursement and progress of the program (European Commission, 2012c; IMF, 2012a). Therefore, this third program review was a condition to release "EUR 15 billion, of which EUR 9.7 billion from the EU and SDR 4.4 billion (about EUR 5.2 billion) from the IMF" (European Commission, 2012c, p. 6). As a result, the Troika's assessment of program implementation had concluded that the program "is on track" and that, "the 2011 budget target has been achieved" (European Commission, 2012c, p. 15). The Troika's report also highlighted that, Portugal's supplementary budget was proposed to clarify and update some developments on the revenue and expenditure side, which are not directly related with social 
citizenship rights (European Commission, 2012c; IMF, 2012a). However, the structural reforms underway under the MoU, such as the ones related with the labour market, in particular the unemployment insurance went through new developments at the time of the third MoU program's review (European Commission, 2012c, p. 33).

That said, as a result of the third MoU's program review, the Troika concluded that the rise of unemployment constituted a higher risk for budgetary execution. The labour market reform, in particular the area related with unemployment benefits, raised further concerns to the Troika's mission which in turn suggested new changes in the duration of the unemployment insurance benefits (European Commission, 2012c, p. 42).

Following the Troika's third review, Portugal submitted its third update to the MoU on March 15, 2012. In the update to the MEFP, the Portuguese government stated that, in 2011, the public deficit "is estimated to have reached 4 per cent of GDP_against a 5.9 per cent of GDP target" (European Commission, 2012c, p. 64). For that reason, the Portuguese authorities reinforced their commitment with a deficit objective of $-4.5 \%$ of GDP which represented a $4 \%$ structural adjustment (European Commission, 2012c).

The Memorandum of Understanding on Specific Economic Policy Conditionality, updated following the Troika's third MoU's program revision defined, on the expenditure side, the following austerity policies for 2012 (Table 29). This third revision introduced deep cuts to the wages of public servants. While the overall budgetary consolidation maintained the limit of $€ 3000$ million, the suspension of the thirteenth and fourteenth-month bonus salary was applied for salaries over $€ 1100$. Salaries between $€ 600$ and $€ 1100$ were penalized (on average and in a progressive way) in one of the two bonuses (European Commission, 2012c, p. 84). The expenditure with regards to public pensions also suffered additional measures. The thirteenth and fourteenth public 
pension monthly bonus over $€ 1100$ were suspended, while pensions between $€ 600$ and $€ 1100$ were penalized (on average and in a progressive way) in one of those two monthly bonuses. Pensions below $€ 600$ were frozen while the lowest ones were marginally increased. The accumulation of pensions was also considered to calculate and determine those penalizations (European Commission, 2012c, p. 84). On the public revenue side, the co-payments (taxas moderadoras) to access the public health care system were also revised to generate estimated revenues of $€ 150$ million in 2012. The unemployment insurance was also revised with the approval of new legislation to change the eligibility and conditionality of the program (European Commission, 2012c, p. 101).

Table 29 - Main Austerity Measures for 2012 on Public Expenditure with Social Citizenship Rights (Third Update - March 2012)

1 Reduction of salaries on public sector by at least $€ 3000$ million

2 Reduction of public pension expenditure in gross terms by at least $€ 1140$ million

3 Savings in public health care system worth in $€ 1000$ million

4 Cuts to public education worth in $€ 380$ million

5 Reduce cash benefits (other than pensions) by at least $€ 180$ million

Source: European Commission (2012c, p. 84-85), The economic adjustment programme for Portugal: third review.

Despite these measures, budgetary consolidation was far from over. The waning of favourable economic conditions and the rise of the unemployment rate paved the way for further austerity measures. The fourth MoU's quarterly review took place between May 22 and June 4, 2012, when a joint-mission from the European Commission, the ECB and the IMF visited Portugal 
to assess the compliance and progress of MoU's program implementation (European Commission, 2012e, 2012f; IMF, 2012c, 2012d).

In a joint-statement released by the Troika's mission on June 4, 2012, it was affirmed that, "the programme remains on track amidst continued challenges." The Troika also stated that the Portuguese "authorities are implementing the reform policies broadly as planned and external adjustment is proceeding faster than expected" (European Commission, 2012f; IMF, 2012d). Although, the Troika assumed that the rise of unemployment and the weaker labour market were pressing concerns, they also affirmed that "temporarily higher unemployment is part of the transition to a more export-oriented economy, but its rise has been exacerbated by Portugal's longstanding labour market rigidities" (European Commission, 2012f; IMF, 2012d). Accordingly, the approval of this fourth review resulted in the disbursement of $€ 4.1$ billion ( $€ 2.7$ billion by the EU, and $€ 1.4$ billion by the IMF).

On June 27, 2012, the Portuguese authorities submitted its fourth update of the MoU (European Commission, 2012e, p. 64-65). In line with the Troika's assessment, the Portuguese authorities also reinforced that the "Economic Adjustment Programme is on track" (European Commission, 2012e, p. 64). The rise of unemployment was also highlighted as a major risk to the budgetary outlook. This fourth update kept the deficit targets already defined $-4.5 \%$ of GDP in 2012 and 3\% of GDP in 2013. However, the need to promote employment through active labour policies became a policy priority (European Commission, 2012e, p. 67).

In response to the need of budgetary consolidation, the Memorandum on Specific Economic Policy Conditionality outlines the main fiscal measures for 2012 and 2013. On the expenditure side with social citizenship rights, the fiscal measures being proposed follow the same ones outlined on Tables 28 and 29 (European Commission, 2012e, p. 82-83). 
In contrast, the Portuguese authorities prepared a stimulus package of active labour policies supported by EU funding. The package plan included programs like Estímulo 2012, Vida Ativa and Impulso Jovem along with the introduction of new rules on unemployment insurance to allow those enrolled in Employment Centers for more than six months, the partial accumulation of 50\% of unemployment benefits with income from any employment activity up to 12 months if the earnings of the job offers were lower than the payable unemployment insurance benefits. The program Vida Ativa was designed to offer training programs to help prepare for employment, selfemployment or career advancement. For example, the Portuguese authorities reported that 67,000 unemployed participants were referred to those training programs while 7000 had already participated in training sessions at the time of MoU's fourth update (European Commission, 2012e, p. 67). The program Estímulo 2012 offered grants to help employers train and hire unemployed workers already enrolled in Employment Centers for more than six months. The Portuguese authorities stated that this program allowed to fill 4,000 job positions and create another 2,000 field placements for vulnerable unemployed participants. Finally, the program Impulso Jovem was designed to support young unemployed with paid internship programs. It also offered tax credits and grants for employers to provide apprenticeship positions (European Commission, 2012e, p. $67)$.

The budgetary consolidation adopted under the $\mathrm{MoU}$ resulted in the sharp rise of unemployment in 2011 and 2012. Therefore, indebtedness in the wake of the 2008 financial crisis led to a long process of fiscal adjustment tied to debt sustainability. The IMF report 12/179 on the fourth review of the MoU classified Portugal's debt trajectory as fragile, which made public expenditure in the welfare state highly sensitive and exposed. The structural reforms in the labour market, conducted under the MoU, was also justified as a necessary condition to promote growth 
and employment in the medium-long term (IMF, 2012c). This package of so-called active labour policies was necessary to revamp public investment in the labour market.

The fifth quarterly review of Portugal's MoU economic program took place in AugustSeptember 2012 (European Commission, 2012g; IMF, 2012e). A joint-mission of the European Commission, the ECB and the IMF visited Portugal between August 28 and September 2012 to assess the fiscal deficit path and program implementation (European Commission, 2012h; IMF, 2012f). In a joint-statement following the visit, the Troika's mission affirmed that the program "remains broadly on track" (European Commission, 2012h; IMF, 2012f). They also stated that "real GDP growth remains in line with projections, exports are performing better than expected, and the fast reduction in the external deficit is contributing to alleviating the external financing constraint" (European Commission, 2012h; IMF, 2012f). The higher unemployment and lower disposable income were seen as the main concerns which directly affected the advance and effectiveness of budgetary consolidation. As a result, the Troika's mission affirmed in its jointstatement that, "growth will remain weak into 2013. In 2012, economic activity was projected to decline by 3 percent" (European Commission, 2012h; IMF, 2012f). It is important to highlight that, the projections of economy declined in 2012 and 2013 and forced the adjustment of the deficit targets for 2012, 2013 and 2014, which in turn brought further austerity measures. Therefore, following this fifth quarterly review, the revised deficit targets were $-5 \%$ of GDP for 2012 and $4.5 \%$ of GDP for 2013. In fact, these revised new deficit targets extended the period of fiscal adjustment for 2014. Nonetheless, the approval of the conclusion of this fifth quarterly review allowed the disbursement of $€ 4.3$ billion ( $€ 2.8$ billion by the EU, and $€ 1.5$ billion by the IMF) (European Commission, 2012h; IMF, 2012f). 
A combination of factors already described gave rise to the revision of fiscal targets. The 2012 budgetary execution initially planned in the State Budget for 2012 and in both third and fourth quarterly reviews went off the targets. The lack of performance of fiscal consolidation was not only explained by the shrinking of economic activity, but also by the rise of public expenditure on unemployment benefits. A decline on the revenue side could also account for the budgetary gap in the first semester of 2012. As unemployment and revenue shortfalls continued to rise, the budgetary execution slowed down. A TC ruling also decided that "the burden of adjustment needs to be more broadly shared" (IMF, 2012e, p. 17). Such ruling changed the government plans and measures to introduce additional tax revenues over income of public employees and pensioners creating as a result a fiscal gap on government budgetary plans.

In a Letter of Intent sent to the Troika on the update to the MoU, the Portuguese authorities described the development of budgetary consolidation undertaken in the first semester of 2012 while highlighting the necessary policy steps to be adopted on both expenditure and revenue sides for the last semester of 2012. The Portuguese authorities affirmed that, "the fiscal outlook has deteriorated considerably, reflecting mainly the impact of the economic rebalancing on tax bases and revenue performance and the more subdued growth projections. In spite of a rigorous budget implementation on the expenditure side, a large fiscal gap has now emerged and the initial programme targets are no longer achievable" (European Commission, 2012g, p. 51). Thus, additional fiscal measures were introduced and the deficit targets were revised.

The update to the MEFP described that GDP had shrunk $1.2 \%$ in the second quarter of 2012, when compared with the first quarter. During this fifth quarterly review, the prediction was that GDP would continue to shrink around 3\% by the end of 2012 (European Commission, 2012g, p. 81). Not to mention the fact that the fiscal consolidation achieved since 2011 resulted in a 
reduction of $5 \%$ on public deficit. However, Portugal's weak economic performance and the macroeconomic environment created the conditions for a fiscal deviation. Thus, the Portuguese authorities proposed additional measures to minimize fiscal deviation and recalibrate the initial fiscal targets in order to reach MoU's objectives. The measures to limit the deficit to -5\% of GDP in 2012 included on the expenditure side, cuts to cash benefits - social assistance, pensions and unemployment insurance. On the revenue side, a new revision of co-payment fees to access the public healthcare system (SNS) directly contributed to generate an additional $€ 150$ million in the last quarter of 2012 .

The update to the Memorandum on Specific Economic Policy Conditionality detailed the newly revised targets and fiscal policies (European Commission, 2012g, p. 53-80). For 2012, the deficit target was revised from $-4.5 \%$ of GDP to $-5 \%$ of GDP ( $€ 8.3$ billion) in order to accommodate the budgetary gap already described. On the expenditure side, the measures related with social citizenship rights resulted in the savings of $0.1 \%$ GDP through the frontloading of some of the measures initially planned for 2013 (European Commission, 2012g, p. 54). For 2013, the public deficit target was revised from 3\% to $4.5 \%$ of GDP (€7.5 billion). Despite the revision of the public deficit target, a TC ruling suspended the government decision to cut the thirteenth and fourteenth-month bonus salary and pensions. The TC ruling ordered the reinstatement of the thirteenth-month bonus salary and of the 1.1 monthly bonus pension (European Commission, 2012g, p. 54).

In order to compensate for this additional fiscal gap, the Portuguese government proposed new permanent austerity measures to be adopted in 2013 . These additional austerity measures were carried out with the State Budget for 2013. The overall account of the measures being introduced were aiming to reduce public expenditure in $1.6 \%$ of GDP. On the expenditure side, cuts to cash 
benefits and other allowances (both public and private) were worth in $€ 1770$ million and the public health care system savings for 2012 were worth $€ 485$ million (European Commission, 2012g, p. 55). On the revenue side, the taxation of all cash benefits was reinforced. On the public health care system, the revisions to co-payment fees introduced in the last quarter of 2012 also provided an additional revenue of $€ 50$ million Euros in 2013 when compared to the initial targets set in the MoU (European Commission, 2012g, p. 63).

In doing so, the Portuguese government began to pave the road to the 2013 State Budget. As stated by IMF, "the announcement of further austerity measures to underpin the 2013 Budget is testing the broad-based political and social consensus that has buttressed the program to date" (IMF, 2012e, p. 4).

The sixth quarterly review of Portugal's MoU took place in November 2012 (European Commission, 2012i; IMF, 2013a). A joint-mission from the European Commission, the ECB and the IMF visited Portugal between November 12 and 19, 2012 to assess the progress of Portugal's three-year financial and economic program. In a joint-statement, the Troika's mission affirmed that "the programme is broadly on track, despite stronger headwinds" (European Commission, 2012j; IMF, 2013b). The rise of unemployment and the lower incomes continued to be a major concern. As the down side risks continued to grow at the end of 2012, the State Budget for 2013 increased the fiscal consolidation even more in order to achieve a deficit target of $-4.5 \%$ of GDP in 2013. Troika's joint-statement also supported the intention of the Portuguese authorities to adopt further and permanent measures to reduce public expenditure. The approval of this sixth quarterly review resulted in an additional sum of $€ 2.5$ billion ( $€ 1.6$ billion by the $\mathrm{EU}$, and $€ 0.9$ billion by the IMF) (European Commission, 2012j; IMF, 2013b). 
The State Budget for 2013 approved new fiscal measures that amounted to more than 3\% of GDP (DRE, 2012a). Such measures were discussed with the Troika's mission during this sixth quarterly program review (European Commission, 2012i; IMF, 2013a). On December 20, 2012, in a Letter of Intent submitted to the European Commission, the ECB and the IMF, the Portuguese authorities introduced the main fiscal measures and policy steps to update the MoU and its fiscal and economic targets for 2013 (European Commission, 2012i, p. 50-51). Illustration 6 shows the distribution of such measures proposed in the 2013 State Budget.

\section{Illustration 6 - Austerity Measures per area in the 2013 State Budget (\% of GDP)}

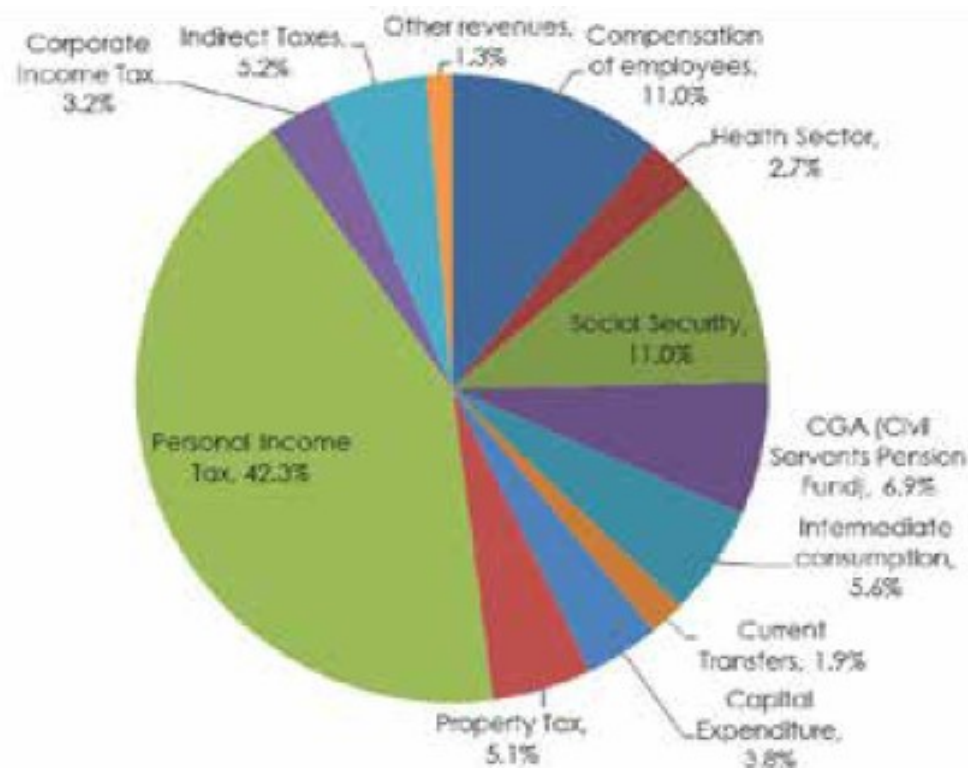

Source: European Commission (2011i, p. 19). The economic adjustment programme for Portugal: sixth review.

The update to the MEFP contextualized and defined the main fiscal policies for 2013, envisaged by the State Budget approved on November 28, 2012. The proposed fiscal consolidation 
was set to achieve a public deficit of $4.5 \%$ by the end of 2013 . The Portuguese authorities affirmed that their main aim was "to refocus the role of the State in Portugal in order to ensure the sustainability, the effectiveness, and the equity of its social functions" (European Commission, 2012i, p. 78).

Consequently, the Memorandum on Specific Economic Policy Conditionality outlined the fiscal policies of the last quarter of 2012 and, more consistently for 2013 and 2014. In order to achieve the public deficit of -5\% of GDP in 2012, the Portuguese authorities frontloaded to 2012 some measures initially planned for 2013. Additional cuts were made over refunds of funeral expenses, and on transfers of cash benefits from deceased and on disability supplements, representing a reduction of $0.1 \%$ GDP (European Commission, 2012i, p. 53).

For 2013, the budgetary consolidation proposed aimed to achieve a maximum public deficit of no more than $-4.5 \%$ of GDP. On the expenditure side, the main measures related directly or indirectly with social citizenship rights is being introduced on Table 30 .

Table 30 - Main Austerity Measures for 2013 on Public Expenditure with Social Citizenship Rights (Sixth Update - December 2012)

1 Reduction of public pension expenditure in gross terms by at least $€ 400$ million

2 Cuts to cash benefits (other than pensions) by at least $€ 450$ million

3 Savings in public health care system worth in $€ 180$ million

Source: European Commission (2012i, p. 53), The economic adjustment programme for Portugal: sixth review.

On the revenue side, social security contributions were extended to public pensions and unemployment benefits, representing an additional revenue of $€ 270$ million. Amendments to 
personal income taxes were also introduced where deductions of social benefits are delinked from the tax structure (European Commission, 2012i, p. 54). The revision of the co-payments fees to access the Public Health Care System (SNS) introduced in the last quarter of 2012 resulted in additional revenues of $€ 50$ million in 2013 (European Commission, 2012i, p. 63).

While important fiscal measures are being proposed for 2013, the budgetary consolidation and the policy effort on structural reforms created significant downside risks like unemployment and income inequality. As Table 14 shows, Portugal ended 2012 with an unemployment rate of 15.53\%. Its public deficit reached 5.56\% of GDP in 2012 (Table 12) and the public debt increased to $137.1 \%$ of GDP (Table 13). Consequently, the public social spending increased from $24.35 \%$ of GDP in 2011 to $24.53 \%$ of GDP in 2012 (Table 16). Public spending on unemployment benefits increased from 1.194\% of GDP in 2011 to $1.540 \%$ of GDP in 2012 (Table 18).

While recession was predicted for 2013, the budgetary consolidation under the MoU's fiscal and economic program continued as planned. In fact, as Table 9 shows that, in 2012, the Real GDP growth fell sharply to $-4.0 \%$. In 2011 the Real GDP growth was $-1.8 \%$ (Table 9). This represented an economic decline of 3.8\% (European Commission, 2013b; IMF, 2013c).

Between February 25 and March 15, a joint-mission from the European Commission, the ECB and the IMF visited Portugal for the seventh quarterly review of Portugal's MoU program. In a joint-press release, the Troika's mission affirmed that the MoU's "implementation remains broadly on track, against the background of difficult economic conditions." They further stated that, "[e]xternal adjustment continued to exceed expectations" (European Commission, 2013b; IMF, 2013c). Subsequently, the Troika's joint mission visited Portugal again between April 14 to 17 and May 8 to 11 for a further assessment of Portugal's compliance with the terms and conditions of the MoU (European Commission, 2013b, 2013c; IMF, 2013c, 2013d). 
During this seventh quarterly review, the Portuguese government requested the revision of the deficit targets from $-4.5 \%$ to $-5.5 \%$ of GDP in 2013 and from $-2.5 \%$ to $-4 \%$ of GDP in 2014 . At the time of this quarterly review, it was expected that by 2015 Portugal would achieve a pubic deficit of $-2.5 \%$ of GDP, in line with the SGP rules, which required a public deficit below $-3 \%$ of GDP (European Commission, 2013b; IMF, 2013c).

In a Letter of Intent sent to the European institutions on June 25, 2013, the Portuguese authorities introduced the developments occurring in the first quarter of 2013 while updating the MoU and defining the next policy steps to pursue the budgetary consolidation under the Troika's bailout program (European Commission, 2013c, p. 66-67). This seventh MoU's quarterly review also faced additional challenges as a result of the unfavourable TC rulings, which forced the Portuguese government to propose new austerity measures to replace the ones included in the 2013 State Budget.

In order to update the MEFP, the Portuguese authorities affirmed that, "economic conditions remain difficult, with unemployment higher and output lower than previously envisaged" (European Commission, 2013c, p. 97). Taking into account the effects of the recession projected for 2013 and the already described fiscal gap of 1\% (in 2013), the Portuguese authorities were predicting that additional and permanent measures worth $2.9 \%$ of GDP were necessary in 2013 (European Commission, 2013c, p. 98). This represented a further break in the initial MoU targets and from the last projections made in the sixth quarterly review (European Commission, 2012i, 2013c).

The update to the MEFP also contextualized the need for the approval of a Supplementary Budget for 2013 since, on April 5, the TC declared some measures of the 2013 State Budget unconstitutional, i.e. cuts in the fourteenth-month bonus salary and pensions, and the new 
contribution on illness and unemployment benefits. The unconstitutionality of these measures had an impact of $€ 1.3$ billion ( $0.8 \%$ of GDP) (European Commission, 2013c, p. 98). As a result, the update to the MEFP outlined new measures including "a minimum threshold for applying the contribution on illness and unemployment benefits" (European Commission, 2013c, p. 98). These measures were included in the 2013 Supplementary Budget (submitted to the Parliament at the time of this seventh review).

The update to the Memorandum on Specific Policy Conditionality unveiled the revised measures being proposed for 2013 and the structural reforms to be adopted (European Commission, 2013, p. 68). As discussed before, the updated and new fiscal policies and targets were aiming to reduce public deficit to $-5.5 \%$ of GDP in 2013 , to $-4 \%$ of GDP in 2014 and to $2.5 \%$ of GDP in 2015 .

This policy document classified the measures being proposed, as permanent expenditurereducing measures. How? The Memorandum on Specific Policy Conditionality unveiled measures that were worth in 3.5\% of GDP for 2013 (European Commission, 2013c, p. 69). On the expenditure side, measures related with social citizenship rights were mainly centered on public health care policies and services and on cash benefits. Table 31 details the impact of the cuts on those areas (European Commission, 2013c, p. 70).

On the revenue side, measures being proposed directly related to citizenship rights were: (1) the rise of premiums paid by public servants to their special health insurance scheme (worth $€ 80$ million); and (2) the introduction of a supplementary contribution to the social security system from the salaries of public servants and on the cash benefits of unemployment insurance and sickness (worth $€ 190$ million) (European Commission, 2013c, p. 71). Other savings were achieved by delinking social citizenship benefits from the tax-system, particularly cutting all tax deductions 
and through improvements in the in the billing of co-payment fees to access the public health care system (SNS).

\section{Table 31 - Main Austerity Measures for 2013 on Public Expenditure} with Social Citizenship Rights (Seventh Update - May 2013)

1 Changes in means-testing procedures of different social benefits (worth $€ 650$ million)

2 Savings in public health care system (worth in $€ 180$ million)

Source: European Commission (2013c, p. 69-70), The economic adjustment programme for Portugal: seventh review.

Thus, these updated fiscal measures on public expenditures with regards to social citizenship rights translated into a more permanent recalibration of social citizenship rights, not only for 2013 but for subsequent years. These measures resulted in direct cuts of social citizenship rights.

The Memorandum on Specific Policy Conditionality also updated the fiscal measures for 2014 since the public deficit target had been reviewed from $-2.5 \%$ to $-4 \%$ of GDP in 2014 . As a result, the new fiscal measures being proposed for 2014 were worth 2\% of the GDP (European Commission, 2013c, p. 72). A comprehensive pension reform was proposed to adjust and reduce the differences from the pension stream of public servants to the general one of the social security system. Changes being introduced have also included the revision of the sustainability factor (increasing the retirement age to 66 years of age) and the revision of the calculation rules to align the all different pension schemes. Changes in pension replacement rates were also introduced in order to raise the lower old-age pensions (European Commission, 2013c, p. 72). 
Following the need to update and propose new measures, structural reforms were continuing to be used to facilitate the fiscal adjustment and foster the reconfiguration of social citizenship rights, in particular public pensions and unemployment insurance (European Commission, 2013c; IMF, 2013d). According to the IMF Country Report No. 13/160, in their seventh quarterly review, Portugal's “unemployment benefit system was one of the most generous in Europe for those covered by the system — entailing significant disincentives, particularly for low-wage workers to seek re-employment for the duration of the benefit - an unemployment benefit reform delinked the benefit from the worker's age, shortened the duration of the benefit, and introduced a declining profile and a cap" (IMF, 2013d, p. 58). Such analysis reflected the Troika's vision about how the allocation of social citizenship rights impacted the "efficiency" of the state.

The eighth and ninth quarterly reviews were combined following the delay of the eighth quarterly review as a result of a political crisis. Other unfavourable TC rulings related with the public expenditure reform and some measures on unemployment insurance led to a momentary political and economic instability (European Commission, 2013e; IMF, 2013e).

Consequently, and despite the political turmoil, the Troika's mission visited Portugal between September 16 and October 3, 2013, to assess the combined eighth and ninth quarterly reviews of MoU's fiscal and economic program (European Commission, 2013d; IMF, 2013f). In a joint-statement, the Troika considered that the "2013 fiscal deficit target of 5.5 percent of GDP is within reach" and "supported by solid revenue performance and improved expenditure control" (European Commission, 2013d; IMF, 2012f). Despite the Court rulings and market concerns over the summer of 2013, the Troika stated that, "the programme's agenda of structural reforms is well advanced, and effective implementation will be key to sustaining competitiveness gains" 
(European Commission, 2012d; IMF, 2012f). In apparent support of the actions taken by the Portuguese authorities, the Troika's joint-statement further affirmed that, "the programme remains broadly on track, with the authorities determined to achieve its objectives" (European Commission, 2012d; IMF, 2012f). The successful approval of these combined eighth and ninth reviews was the condition to release "the disbursement of $€ 5.6$ billion ( $€ 3.7$ billion by the EU, and about $€ 1.9$ billion by the IMF)" (European Commission, 2012d; IMF, 2012f).

The Portuguese authorities undertook further measures in order to meet the targets required under the eighth and ninth combined review. In a Letter of Intent sent to the European authorities on November 21, 2013, the Portuguese authorities introduced the progress made and the steps to be adopted during the last quarter of 2013, in order to achieve a public deficit of $-5.5 \%$ of GDP by the end of the year, as well as for 2014 (European Commission, 2013e).

Portugal's macroeconomic outlook improved in the second and third quarter of 2013, for the first time since 2010. However, economic contraction was expected for the fourth quarter of the year. Although the unemployment rate had declined from $17.7 \%$ (second quarter) to $16.4 \%$ (third quarter), it has still affected the process of fiscal consolidation and economic recovery (European Commission, 2013e; IMF, 2013e).

The eighth and ninth update to the MEFP reported that the end of June targets were met. Some additional challenges like budgetary overruns and revenue shortfalls (of $0.8 \%$ GDP) were being described by the Portuguese authorities to justify a further adjustment for 2014 (European Commission, 2013e, p. 92). An updated review of public expenditure was included in the proposal of the State Budget for 2014 (Budget Law-Project No. 178/XII), later approved and published on December 31, 2013 (DRE, 2013a). 
The MEFP's update outlined the main targets of an updated public expenditure review. Particular attention had to be given to the pension reform being proposed, which was expected to “to generate 0.6 billion [Euros] of net savings" (European Commission, 2013e, p. 94). The pension reform prioritized three key dimensions: (1) increase the minimum mandatory retirement age to 66 years of age; (2) match the rules and benefits of the public servants' scheme with the social security general scheme (equalize a similar replacement rate of $80 \%$ to all beneficiaries); and (3) apply means-testing rules for survivors' pensions in case of accumulation with other pension benefits (European Commission, 2013e, p. 94).

With regards to the update to the Memorandum on Specific Policy Conditionality, the Portuguese government adopted measures under the 2013 Supplementary Budget in order to achieve a public deficit of $-5.5 \%$ by the end of 2013 . While the fiscal consolidation for 2014 , worth in $2.3 \%$ of GDP, aim to achieve a public deficit of $-4 \%$ of GDP by the end of the year (European Commission, 2013e, p. 67). The pension reform already described above represented an "additional savings of around EUR 700 million in gross terms (around EUR 600 million net savings)" (European Commission, 2013e, p. 68). The progressive penalization placed in 2013 on one of the two public pensions monthly bonus continued to be applied in 2014. Other cuts to public expenditure in 2014 included additional "savings" of around $€ 1850$ million (€1650 million in net terms) in the public health care system (European Commission, 2013e, p. 69). The measures and structural reforms introduced to unemployment insurance naturally continued to be applied in 2014. Illustration 7 shows the evolution and impact of the measures and structural reforms adopted on cash benefits of social citizenship rights between January and August 2013 when compared with the previous year of 2012 (European Commission, 2013e, p. 11). Meanwhile in the public health sector, the measures adopted under the umbrella of the so-called structural reforms had an 
impact of $-11 \%$ of GDP on public expenditure in the public health care system, which represented a drop from $€ 818$ million in 2010 to a forecast of $€ 65$ million in 2013 (European Commission, 2013e, p. 25).

\section{Illustration 7 - Budgetary Outturn on Cash Benefits of Social Security (January-August 2013)}

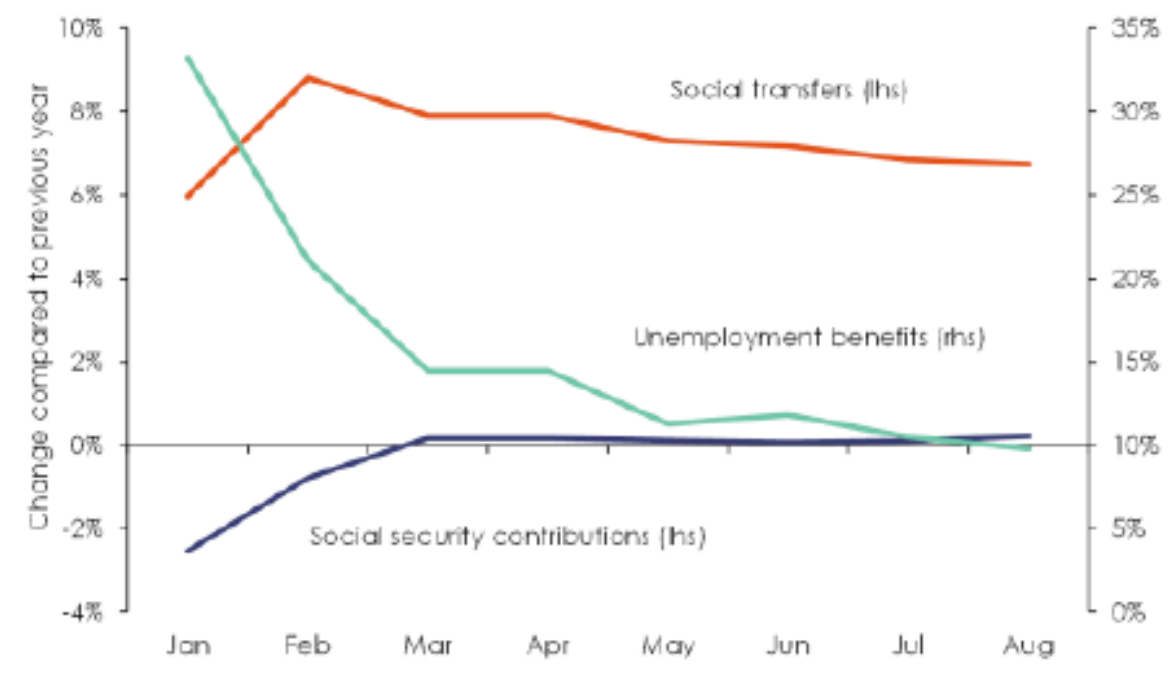

Source: European Commission (2013e, p. 11). The economic adjustment programme for Portugal: eighth and ninth review.

Contrary to what one may have expected, Portugal's public social spending has been increasing consistently since 2011. In fact, in 2013, the country registered social spending of $25.50 \%$ of GDP when compared with the $24.53 \%$ of GDP in 2012 and with the $24.36 \%$ of GDP in 2011 (Table 16). However, the unemployment rate hit a peak of $16.18 \%$ in 2013 when compared with the $15.53 \%$ registered in 2012 (Table 14). In fact, unemployment spending increased in 2013, registering $1.608 \%$ of GDP when compared with the $1.540 \%$ of GDP in 2012. In part, the goal of 
boosting the economy and promoting growth, while pursuing budgetary consolidation, was carried out. The Annual Growth Rate (GDP forecast) increased to 2.9\% in 2013 (-1.1\%), when compared with $2012(-4.0 \%)$ (Table 9).

The tenth quarterly review of MoU's program occurred between December 4 and 162013 , when a joint-mission from the European Commission, the ECB and the IMF visited Portugal (European Commission, 2013f; IMF, 2013g). In a joint-statement the Troika stated that, "signs of recovery have emerged since the last review. Growth is broadly in line with projections, while unemployment has fallen by more than expected" (European Commission, 2013f; IMF, 2013g). Despite the temporary political turmoil and the unfavorable TC rulings over the summer 2013, the economic and fiscal adjustment program remained within its objectives. While the public deficit targets were redefined, the Troika's mission was pleased by the efforts made by the Portuguese authorities, particularly with the approval of further austerity measures in the State Budget for 2014 aiming to achieve a public deficit of $-4 \%$ of GDP in 2014 (DRE, 2013a; European Commission, 2013f; IMF, 2013g). The successful approval of this tenth review by EU authorities and IMF resulted in the disbursement of $€ 2.7$ billion ( $€ 1.8$ billion by the $\mathrm{EU}$, and about $€ 0.9$ billion by the IMF) (IMF, 2013g).

The Portuguese authorities submitted their Letter of Intent after the tenth quarterly review on February 19, 2014. While updating the progress made by describing the targets achieved, they also outlined the steps of the ongoing structural reforms being conducted, particularly on public pensions and unemployment insurance (European Commission, 2014a, p. 73-74).

Thus, the tenth update to the MEFP outlined the key measures (worth in 2.3\% of GDP) approved by the State Budget for 2014 (DRE, 2013a; European Commission, 2014a). The ambitious public expenditure review, as the Portuguese authorities called it, faced other challenges 
as a result of another unfavourable TC decision on December 19, 2013, regarding some provisions of the pension reform (European Commission, 2014a, p. 103). The TC decision ruled unconstitutional the alignment of the public servants' pension scheme (CGA) with the Social Security general pension scheme, which was projected to generate revenues of $€ 321$ million $(0.2 \%$ of GDP) in net terms (European Commission, 2014a, p. 21). The outcome of these TC rulings produced other measures of equal value.

With regards to the fiscal measures for 2014, the update to the Memorandum on Specific Economic Policy Conditionality offered a detailed account of the measures to achieve a public debt ceiling of $-4 \%$ of GDP in 2014 . The measures proposed to be adopted throughout the year were $80 \%$ on the expenditure side (European Commission, 2014a, p. 77). This adjustment package of permanent austerity measures represented $1.8 \%$ of GDP on the expenditure side. One of the pillars of this package was to reduce public pension expenditure by tying sustainability to demographic development. Measures introduced included: (1) an increase by one year (to 66 years of age) to the minimum retirement age by applying what the government calls a "demographic sustainability factor"; (2) a continuation of a temporary penalization, called "extraordinary solidarity contribution" (CES), which was applied progressively (i.e., down from $€ 1350 /$ month to $€ 1000 /$ month); and (3) means-testing of survivors' pensions in order to avoid accumulation with other pensions. According to the Memorandum on Specific Economic Policy Conditionality, these measures represented cuts and revenues worth $€ 450$ million in gross terms in 2014 (around $€ 380$ million in net savings) (European Commission, 2014a, p. 78).

As detailed in the European Commission's report on the tenth review (Occasional Papers 171, February 2014), the continued budgetary consolidation and structural reforms carried were 
seen as "a credible strategy for sustainable growth in the medium term" (European Commission, 2014a, p. 4).

Between February 20 and 28, 2014, in a last effort to assess compliance with the conditions set out in the MoU, the eleventh and last MoU's quarterly review led by a joint-mission composed of representatives of the European Commission, the ECB and the IMF took place (European Commission, 2014b; IMF, 2014b). Following this last assessment of MoU's program before the adjustment program ended, the Troika's mission stated that Portugal's economic and fiscal adjustment program continued on track in the first quarter of 2014 and that economy was recovering well with direct results in the decline of the unemployment rate. Therefore, the public deficit target of $-4.0 \%$ of GDP remained stable as previously planned. The approval of this eleventh review represented the disbursement of $€ 2.5$ billion ( $€ 1.6$ billion by the $\mathrm{EU}$, and about $€ 0.9$ billion by the IMF) (European Commission, 2014b; IMF, 2014b).

Not pressured by the end of the fiscal and economic program, the Portuguese government submitted, on April 23, 2014, another Letter of Intent to the representatives of the European institutions on the eleventh review in order to update the progress made and the policy steps undertaken towards the consolidation targets set in the MoU and subsequently on several program updates (European Commission, 2014c, p. 77-79). The Portuguese authorities affirmed and reinforced the commitment to continue the budgetary consolidation and structural reforms being adopted to meet the public deficit target of $-4.0 \%$ of GDP.

The update to the MEFP explored the progress achieved and the recent steps of the ongoing pension reform which, according to the Portuguese authorities, aimed to achieve "the long-term sustainability of the pension system" (European Commission, 2014c, p. 107). Pensions entitlements were therefore being tied to demographic and economic criteria. 
The update to the Memorandum on Specific Economic Policy Conditionality also reinforced the package of the measures being proposed for 2014, particularly the permanently limiting of public pension expenditure representing expenditure cuts and increased revenues of $€ 450$ million in 2014 (in gross terms), which led to approximately $€ 380$ million in net savings (European Commission, 2014c, p. 82). As mentioned before, key measures of this pension reform included an increase by one year of the minimum legal retirement age to 66 years of age (by applying what the Portuguese government called the demographic sustainability factor) and by extending the temporary penalization, called "extraordinary solidarity contribution" (CES), which was applied progressively (i.e., down from $€ 1350 /$ month to $€ 1000 /$ month) (European Commission, 2014c, p. 82). These measures drew from a similar analysis like the one highlighted in IMF report on the eleventh review which claimed that public pension expenditure represented the larger share of public spending. The report stated that "in 2012, social benefit spending-of which pensions account for over 80 percent—-stood well above European and euro area averages” (IMF, 2014c. p. 26).

The twelfth and last quarterly review should have occurred in May 2014. A joint-mission from the European Commission, the ECB and the IMF visited Portugal, between April 22 and May 2, to assess the compliance and final policy steps before the end of MoU's adjustment program on May 18, 2014 (European Commission, 2014d; ESM, 2014; IMF, 2014d). The Troika's mission stated that "Portugal's access to sovereign debt markets has improved markedly amid robust investor demand and sharply declining yields" (European Commission, 2014d; IMF, 2014d). The Troika's further affirmed that "with the programme ending, it will be essential that Portugal commits to sound economic policies for the medium term" (European Commission, 2014d; IMF, 2014d). The conclusion and approval of this final twelfth review would have represented the 
disbursement of $€ 2.6$ billion ( $€ 1.7$ billion by the EU, and about $€ 0.9$ billion by the IMF). Nonetheless, the Portuguese authorities have not completed the conclusion of the twelfth and last review, and consequently have not received the final disbursement of $€ 2.6$ billion (IMF, 2014e). Portugal has successfully concluded its fiscal and economic adjustment program financed by the EFSF/EFSM and IMF on May 18, 2014 (ESM, 2014). As a result, and following some pending TC rulings in June 2014, the Portuguese authorities did not request an extension of the program to conclude the twelfth and final quarterly revision (IMF, 2014e).

\section{Changes on cash-benefits}

Last, the legislative policy outcomes adopted on cash benefits are outlined on Table 32. A wide range of measures and structural reforms were adopted between 2011-2014 under the MoU signed with the Troika. The Portuguese authorities introduced several changes in cash benefits of social citizenship rights - minimum income (social assistance), unemployment insurance and pensions. Measures focused on the eligibility criteria to either access those cash benefits, or on their degree of coverage, duration and generosity of the benefits being provided.

These policy measures (Table 32), enacted through legislation, translate and operationalize the cuts to public expenditure with cash benefits of social citizenship rights and the structural reforms, both adopted under the PEC IV (Stability Programme 2011-2014) and the MoU. They also represent compensatory actions and measures in response to the fiscal and economic impact of the MoU on Portuguese society. 
Table 32 - Legislative Measures on Cash Benefits of Social Citizenship Rights (April 2011 - May 2014)

\begin{tabular}{|c|c|c|c|c|c|}
\hline \multirow{2}{*}{ Measures } & \multirow{2}{*}{$\begin{array}{c}\text { Social } \\
\text { Citizenship } \\
\text { Program }\end{array}$} & \multirow{2}{*}{ Year } & \multicolumn{3}{|c|}{ Type } \\
\hline & & & Retrenchment & Compensation & Other \\
\hline $\begin{array}{c}\text { Ministerial Order } \\
\text { (Portaria) } \\
\text { No. 164/2011 } \\
\text { of April } 18\end{array}$ & $\begin{array}{l}\text { GMI }(R S I) \\
\text { Unemployment } \\
\text { Insurance }\end{array}$ & 2011 & -- & Yes & -- \\
\hline $\begin{array}{c}\text { Ministerial Order } \\
\text { (Portaria) } \\
\text { No. 249/2011 } \\
\text { of June } 22\end{array}$ & GMI $(R S I)$ & 2011 & -- & -- & Yes \\
\hline $\begin{array}{c}\text { Law }(\text { Lei }) \\
\text { No. 64-B/2011 } \\
\text { of December } 30\end{array}$ & Old-Age Pensions & 2011 & Yes & -- & -- \\
\hline $\begin{array}{c}\text { Ministerial Order } \\
\text { (Portaria) } \\
\text { No. 36/2012 } \\
\text { of February } 8\end{array}$ & GMI $(R S I)$ & 2012 & -- & Yes & -- \\
\hline $\begin{array}{c}\text { Decree-Law } \\
\text { (Decreto-Lei) } \\
\text { No. 64/2012 } \\
\text { of March } 15\end{array}$ & $\begin{array}{l}\text { Unemployment } \\
\text { Insurance }\end{array}$ & 2012 & Yes & Yes & -- \\
\hline $\begin{array}{c}\text { Decree-Law } \\
\text { (Decreto-Lei) } \\
\text { No. 85-A/2012 } \\
\text { of April } 5\end{array}$ & Old-Age Pensions & 2012 & Yes & -- & -- \\
\hline $\begin{array}{c}\text { Decree-Law } \\
\text { (Decreto-Lei) } \\
\text { No. 133/2012 } \\
\text { of June } 27\end{array}$ & GMI $(R S I)$ & 2012 & Yes & -- & -- \\
\hline $\begin{array}{c}\text { Ministerial Order } \\
\text { (Portaria) } \\
\text { No. 241/2012 } \\
\text { of August } 10\end{array}$ & Old-Age Pensions & 2012 & Yes & -- & -- \\
\hline $\begin{array}{c}\text { Ministerial Order } \\
\text { (Portaria) } \\
\text { No. 257/2012 } \\
\text { of August } 27\end{array}$ & GMI $(R S I)$ & 2012 & Yes & -- & -- \\
\hline
\end{tabular}




\begin{tabular}{|c|c|c|c|c|c|}
\hline $\begin{array}{c}\text { Law }(\text { Lei }) \\
\text { No. 66-B/2012 } \\
\text { of December } 31\end{array}$ & $\begin{array}{l}\text { Old-Age Pensions } \\
\text { Unemployment } \\
\text { Insurance }\end{array}$ & 2012 & Yes & -- & -- \\
\hline $\begin{array}{c}\text { Ministerial Order } \\
\text { (Portaria) } \\
\text { No. 432-A/2012 } \\
\text { of December } 31\end{array}$ & Old-Age Pensions & 2012 & -- & Yes & -- \\
\hline $\begin{array}{c}\text { Clarification } \\
\text { Statement } \\
\text { (Declaração de } \\
\text { Ratificação) } \\
\text { No. 2/2013 } \\
\end{array}$ & Old-Age Pensions & 2013 & Yes & -- & -- \\
\hline $\begin{array}{c}\text { Decree-Law } \\
\text { (Decreto-Lei) } \\
\text { n. } \mathbf{3} / \mathbf{2 0 1 3} \\
\text { of January } 10\end{array}$ & Old-Age Pensions & 2013 & Yes & -- & -- \\
\hline $\begin{array}{c}\text { Decree-Law } \\
\text { (Decreto-Lei) } \\
\text { No. 13/2013 } \\
\text { of January } 25\end{array}$ & $\begin{array}{c}\text { GMI }(R S I) \\
\text { Old-Age Pensions } \\
\text { Unemployment } \\
\text { Insurance }\end{array}$ & 2013 & Yes & -- & Yes \\
\hline $\begin{array}{c}\text { Law }(\text { Lei) } \\
\text { No. 39/2013 } \\
\text { of June } 21\end{array}$ & Old-Age Pensions & 2013 & & Yes & -- \\
\hline $\begin{array}{c}\text { Ministerial Order } \\
\text { (Despacho) } \\
\text { No. 13263/2013 } \\
\text { of October } 17\end{array}$ & $\begin{array}{l}\text { Unemployment } \\
\text { Insurance }\end{array}$ & 2013 & -- & -- & Yes \\
\hline $\begin{array}{c}\text { Law }(\text { Lei }) \\
\text { No. 83-C/2013 } \\
\text { of December } 31\end{array}$ & Old-Age Pensions & 2013 & Yes & -- & -- \\
\hline $\begin{array}{c}\text { Decree-Law } \\
\text { (Decreto-Lei) } \\
\text { No. 167-E/2013 } \\
\text { of December } 31\end{array}$ & Old-Age Pensions & 2013 & Yes & -- & -- \\
\hline $\begin{array}{c}\text { Ministerial Order } \\
\text { (Despacho) } \\
\text { No. 378-B/2013 } \\
\text { of December } 31\end{array}$ & Old-Age Pensions & 2013 & -- & Yes & -- \\
\hline $\begin{array}{c}\text { Ministerial Order } \\
\text { (Portaria) } \\
\text { No. 378-G/2013 } \\
\text { of December } 31\end{array}$ & Old-Age Pensions & 2013 & Yes & -- & -- \\
\hline
\end{tabular}




\begin{tabular}{c|c|c|c|c|c}
\hline $\begin{array}{c}\text { Ministerial Order } \\
\text { (Portaria) } \\
\text { No. 378-H/2013 } \\
\text { of December 31 }\end{array}$ & $\begin{array}{c}\text { GMI }(R S I) \\
\text { Unemployment } \\
\text { Insurance }\end{array}$ & 2013 & -- & Yes & -- \\
\hline $\begin{array}{c}\text { Ministerial Order } \\
\text { (Portaria) } \\
\text { No. 20-B/2014 } \\
\text { of January 30 }\end{array}$ & $\begin{array}{c}\text { GMI }(R S I) \\
\text { Unemployment } \\
\text { Insurance }\end{array}$ & 2014 & -- & Yes & - \\
\hline $\begin{array}{c}\text { Law (Lei) } \\
\text { No. 13/2014 } \\
\text { of March 14 }\end{array}$ & Old-Age Pensions & 2014 & Yes & -- & - \\
\hline
\end{tabular}

Source: Portugal's Social Security website: $\underline{w w w . s e g-s o c i a l . p t / l e g i s l a c a o ~}$

As growing fiscal consolidation led to the approval of cuts to social spending, changes were made in the eligibility to access different cash benefits of social citizenship rights and restrictions on the coverage and generosity of the of the programs (as outlined on Table 1), either through means-testing or by promoting work (known as workfarism) and vocational training (Ferguson et al., 2018; Gilbert, 2013; Pierson, 2001).

These policy outcomes have had a direct impact on the nature and role of the state in welfare provision and redistribution as part of citizenship rights (Briggs, 1961; Esping-Andersen, 1990; Marshall, 1950). Moreover, they translate the recommodification of needs which constitutes the effort to reverse the process of decommodification of public welfare provision (Ferguson et al., 2018; Gilbert, 2013; Pierson, 2001). Consequently, such policy changes affected directly the “degree of equalization" achieved through the rights of social citizenship (Marshall, 1950). In other words, these policy changes on cash benefits of social citizenship rights have certainly had a severe impact on economic equality, one of the most distinctive forms of equality, which relates to the access to and the distribution of material resources of income and wealth in various forms (Moscovitch, 1981). 
However, as discussed in Chapter II, the analysis of social stratification and income inequality can contribute to determine the nature of welfare provision and its forms of redistribution. For Marshall (1950) and Miller (1995), social equality (or equality of status) ensures that everyone meets their most basic needs through the rights of citizenship (White, 2007). Therefore, the degree and levels of social equality (equality of status) in society are determined or can be achieved by the elimination of social disadvantage (economic and social inequality) within society (Marshall. 1950). Thus, income inequality and poverty levels are two important dimensions needed to understand and assess the impact of the politics of austerity in the public welfare provision of cash benefits of social citizenship rights (Esping-Andersen, 1990; Marshall, 1950). The levels and degree of social and economic inequalities can be determined by the income inequality (Gini coefficient) (Table 33) and poverty rate (Table 34) indicators (OECD, 2018v, 2018x).

Table 33 - Portugal's Income Inequality - Gini coefficient (2007-2015)

\begin{tabular}{lcccccccc}
\multicolumn{8}{c}{$0=$ complete equality; $1=$ complete inequality } \\
\hline $\mathbf{2 0 0 7}$ & $\mathbf{2 0 0 8}$ & $\mathbf{2 0 0 9}$ & $\mathbf{2 0 1 0}$ & $\mathbf{2 0 1 1}$ & $\mathbf{2 0 1 2}$ & $\mathbf{2 0 1 3}$ & $\mathbf{2 0 1 4}$ & $\mathbf{2 0 1 5}$ \\
\hline 0.361 & 0.355 & 0.337 & 0.341 & 0.337 & 0.337 & 0.341 & 0.338 & 0.336 \\
\hline
\end{tabular}

Source: OECD, 2018, Income inequality (indicator). doi: 10.1787/459aa7f1-en (Accessed on June 5, 2018)

Table 33 shows that, Portugal's income inequality measured through the Gini coefficient dropped from 0.361 in 2007 to 0.341 in 2010 . In 2011 and 2012, income inequality dropped to 0.337, reaching levels of 2009 when Portugal adopted a budgetary stimulus. During Portugal's financial assistance program (2011-2014), income inequality only increased to 0.341 in 2013 , 
which was the same level registered in 2010, but still lower than the ones occurred in 2007 and 2008 (OECD, 2018v).

\begin{tabular}{llllllllll}
\hline \multicolumn{7}{c}{ Table } & 34 & - Portugal's Poverty Rate - Total, Ratio (2007-2015) \\
\hline $\mathbf{2 0 0 7}$ & $\mathbf{2 0 0 8}$ & $\mathbf{2 0 0 9}$ & $\mathbf{2 0 1 0}$ & $\mathbf{2 0 1 1}$ & $\mathbf{2 0 1 2}$ & $\mathbf{2 0 1 3}$ & $\mathbf{2 0 1 4}$ & $\mathbf{2 0 1 5}$ \\
\hline 0.128 & 0.112 & 0.116 & 0.110 & 0.114 & 0.129 & 0.135 & 0.135 & 0.126 \\
\hline
\end{tabular}

Source: OECD, 2018, Poverty rate (indicator). doi: 10.1787/0fe1315d-en (Accessed on June 5, 2018)

While Portugal's poverty rate $^{2}$ (Table 34 ) increased consistently and significantly between 2010, when it reached 0.110, and 2014, when it got to 0.135, the highest ratio since 2007 (OECD, 2018x). This indicator provides an effective account of the impact of the austerity cuts to the cash benefits of social citizenship rights in Portugal outlined on Table 32.

The analysis of the legislative policy outcomes adopted on cash benefits provided in Table 32 allows to establish a pattern in the process of welfare retrenchment under the paradigm of austerity, which may have considerably damaged the degree of decommodification of welfare provision and redistribution as part of citizenship rights (Briggs, 1961; Esping-Andersen, 1990; Ferguson et al., 2018; Gilbert, 2013; Marshall, 1950; Pierson, 2001). Below, some key changes introduced to each of the three cash benefits of social citizenship rights outlined above in Table 32 are being are described.

For example, in 2012, Decree-Law No. 64/2012 of March 15, 2012 amended for the fourth time the Unemployment Insurance Act (Decree-Law No. 220/2006, of November 3, later amended

\footnotetext{
${ }^{2}$ OECD definition of poverty rate (Table 34): "Ratio of the number of people (in a given age group) whose income falls below the poverty line; taken as half the median household income of the total population."
} 
by Decree-Law No. 68/2009, of March 20, by Law No. 5/2010, of May 5, and by Decree-Law No. 72/2010, of June 18) (DRE, 2012b). This fourth amendment adopted six key measures on unemployment insurance, four on retrenchment and three on compensation. The retrenchment measures were: (1) reduction of $10 \%$ after a six-month benefit period [Article 28, No. 2]; (2) reduction of the maximum rate of insurable earnings for 2.5 times the IAS (Social Support Index) rate [Article 29, No. 1]; (3) reduction of the payable benefits from 270 to 210 days for claimants under 30 years of age with 15-24 months of insurable earnings [Article 37, No. 1, a), ii)]; reduction of the payable benefits from 360 to 330 days for claimants under 30 years of age with more than 24 months of insurable earnings [Article 37, No. 1, a), iii)]; reduction of the payable benefits from 360 to 330 days for claimants between 30-39 years of age with 15-24 months of insurable earnings [Article 37, No. 1, b), ii)]; reduction of the payable benefits from 540 to 360 days for claimants between 40-49 years of age with 15-24 months of insurable earnings [Article 37, No. 1, c), ii)]; and (4) reduction of the length of the benefit period from 720 to 540 days for claimants between 40-49 years of age with more than 24 months of insurable earnings [Article 37, No. 1, c), iii)] (DRE, 2012b, p. 1239). The compensation measures were: (1) a reduction of the qualifying period for unemployment benefits from 450 (15 months) to 360 days (12 months) [Article 22, No. 1]; (2) a $10 \%$ rate increase over the total amount of payable benefits for claimants with children, either for single parents or when both adults in the household are unemployed [Article 2, No. 1, a) and b)]; and (3) partial payment of benefits for claimants who submit a project to become business owners [Article 34-A, No. 1 and 2] (DRE, 2012b).

Another finding on policy change was, for example, Decree-Law No. 85-A/2012 of April 5,2012 , that suspended the special regime for early retirement for old-age pensions (established 
by the Decree-Law No. 187/2007, of May 10, and by Law No. 64-A/2008, of December 31) at 55 years of age, for contributors with 30 years of relevant retirement benefits (DRE, 2012c).

Decree-Law No. 133/2012 of June 27, 2012 introduced changes on several cash benefits on the minimum income program and on the means-testing rules (Condição de Recursos) (within the Social Security Subsystem for solidarity); on unemployment insurance, specifically on maternity, paternity, and adoption leaves, and on survivor's pensions (all within the Providential System); and on family allowances (DRE, 2012d). Findings related to the minimum income program (RSI) show that such legislation amended the minimum income (RSI) program by establishing a new framework (previously defined by Law No. 13/2003, of May 21; Law No. 13/2003, of May 21, republished by the Clarification Statement No. 7/2003, of May 29; by Law No. 45/2005, of August 29; and by the Decree-Law No. 70/2010, of June 16) and changing several rules related to means-testing (income, assets and fraud), household definition, financial need, calculation of benefits and mandatory job search contract (known as Contrato de Inserção) (DRE, 2012d, p. 3273). Decree-Law No. 133/2012 of June 27, 2012 was later regulated by Ministerial Order (Portaria) No. 257/2012 of August 27, 2012 (DRE, 2012e).

In 2013, Decree-Law No. 167-E/2013 of December 31, 2013 introduced several changes on old-age pension (DRE, 2013b). A new formula tied to life expectancy was introduced to determine the sustainability factor that defines the eligibility of the standard minimum age for retirement - 65 years of age in addition to the number of months calculated through the sustainability factor formula (DRE, 2013b, p. 7050-366). 


\section{Conclusion}

This chapter sought to provide a detailed account of the austerity measures adopted in Portugal between 2010 and 2014 to the cash benefits of social citizenship rights - minimum income (social assistance), unemployment insurance and old-age pensions. First, the macroeconomic scenario of Portugal at the beginning of the 2008 financial crisis was introduced. Second, the four Stability Programmes (PEC I, II, III and IV) were analyzed. Third, a detailed account of austerity measures adopted under the Memorandum of Understanding (MoU) signed between Portugal and the Troika (composed of the European Commission, the ECB and the IMF) in May 2011, and then reviewed and updated by eleven quarterly reviews between September 2011 and May 2014 was provided.

The findings showed that the budgetary consolidation carried out in Portugal between 2011 and 2014 was supported by fiscal-structural measures to control public expenditure. Moreover, it was demonstrated that, while severe cuts were applied on public expenditure on social citizenship rights particularly on cash benefits, such as the minimum income program (RSI), unemployment insurance and old-age pensions, the main aim of such measures was to carry out structural reforms in the labour market policies, particularly on unemployment insurance, and on public pensions.

In sum, this chapter analyzed policy findings that summarize the austerity measures introduced between 2010 and 2014. It details the policy outcomes of a broad range of measures and structural reforms conducted under the MoU.

Finally, the next chapter interprets the findings by revisiting the research questions in reference to the literature, offers contributions to the knowledge and provides recommendations for policy directions and future research. 


\section{VI: Discussion chapter}

\section{Introduction}

The analysis of the retrenchment of the welfare state in modern capitalist economies under the paradigm of austerity is of significant importance. This dissertation in social work looked into the austerity measures adopted in Portugal between March 2010 and May 2014 as determined by the targets and commitments set out by the Portuguese authorities on four Stability Programmes (between 2010 and 2011) and on the Memorandum of Understanding signed between Portugal and the Troika (composed by the European Commission, the ECB and the IMF) in May 2011 which, under the terms of the bailout program, was reviewed and updated by eleven quarterly reviews (between September 2011 and May 2014).

The findings of Portugal's budgetary consolidation between 2010 and 2014 help to understand and determine the harsh impact of the politics of austerity carried out in Portugal. The reduction in public spending and the cumulative effect of multiple policy changes in exchange for a $€ 78$ billion financial bailout were very damaging to the entitlements of social protection.

I was primarily interested in analyzing the process of welfare retrenchment in Portugal under the paradigm of austerity which started after the 2008 financial crisis. The goal of this research was to understand how and to what extent did the 2008 financial crisis and the politics of austerity that followed (2010-2014) change the nature of the welfare state in Portugal? This was my primary research question. While some literature has already explored the process of retrenchment of the welfare state and highlighted its key retrenchment components, such as Ferguson et al. (2018), Pierson (2001) and Gilbert (2013), Portugal's financial and economic crisis 
represented an opportunity for a more detailed analysis of the process of welfare retrenchment under the paradigm of austerity.

The second research question that guided this investigation was this: since the 2008 financial crisis, what was the impact of austerity on social citizenship rights caused by the measures adopted under the Stability Programmes (between 2010 and 2011) and the Memorandum of Understanding (between May 2011 and May 2014)? Thus, I will begin this discussion by providing an overview of the findings. I will also discuss the impact and outcomes of those austerity measures by analyzing selected indicators of OECD secondary data.

\section{Interpretation of findings: revisiting research questions}

After doing this research, I can now claim that the 2008 financial crisis incorporated the neoliberal leitmotif of financial and economic sustainability for setting a new stage of welfare retrenchment in the EU. Southern European countries like Portugal were caught in the process by a "market justice" narrative sponsored by an EU policy agenda that constitutionalized balancedbudgets rules.

The primary research question of this study was to understand how and to what extent did the 2008 financial crisis and the politics of austerity that followed (2010-2014) change the nature of the welfare state in Portugal? While the findings of this research tell a complex story, they embody a set of evidence that show the strong impact of austerity in Portugal and particularly on the nature and degree of public welfare provision and redistribution. What were the primary causes for Portugal to have a public deficit of $-11.17 \%$ of GDP in 2010 (Table 12) and a public debt of 104.1\% of GDP (Table 13) (OECD, 2018j, 20181)? Was the welfare state spending responsible for 
such a deficit and debt? How did the public deficit increase from $-3.77 \%$ of GDP in 2008 (Table 3) to $-11.17 \%$ of GDP (Table 12) in 2010? Findings show that the explosion of the Portuguese debt between 2008 and 2010 was caused by a combination of factors, among which were: (1) the abrupt economic recession shown by the decline of the Real GDP forecast (which measures the $\%$ of annual growth rate) that dropped from $2.5 \%$ in 2007 to $0.2 \%$ in 2008 and to $-3.0 \%$ GDP in 2009 (OECD, 2018g, 2018n); (2) the fall of household disposable income (net, \% of annual growth rate) from $1.22 \%$ in 2007 to $1.09 \%$ in 2008 and $0.71 \%$ in 2010 (OECD, 2018f); (3) the rise of the unemployment rate from $7.55 \%$ in 2008 to $10.77 \%$ in 2010 (OECD, 2018c, 2018m); and (4) the rise of the long-term interest rates paid by Portugal on 10-year bonds, from $4.52 \%$ in 2008 to $5.4 \%$ in 2010 (Illustration 3) (OECD, 2018d, 2018i). While the combination of all these factors contributed decisively to the rise of public deficit and debt between 2008 and 2010, the nationalization (bailout) of the BPN national bank (Banco Português de Negócios) in November 11,2008 , and the recapitalization scheme created to support the banking system, initially with $€ 4$ billion Euros, permit us to establish a causal relation between the banking crisis and the sharp rise of public deficit between 2008 and 2010. Portugal's public debt also increased from 82.8\% of GDP in 2008 to $96.1 \%$ of GDP in 2009 and to $104.1 \%$ of GDP in 2010 (Tables 4 and 13) (OECD, 2018b, 20181). How did public social spending play a role, directly or indirectly, in the sharp rise of such public debt? The OECD indicator of Portugal's public social spending (Tables 6 and 16) shows the rise of social spending from $22.22 \%$ of GDP in 2008 to $24.48 \%$ of GDP in 2010 , however my research demonstrates that such evidence embodies different factors associated with class inequality - income inequality, poverty levels, aging and unemployment. Higher public spending does not necessarily lead to higher public deficits and debt, as demonstrated in Tables 12, 13 and 16. When in 2010 Portugal's public deficit increased to $-11.17 \%$ of GDP (Table 12) and the public 
deficit to $104.1 \%$ of GDP (Table 13), the overall public social spending in the same year dropped slightly from $24.58 \%$ of GDP in 2009 to $24.48 \%$ of GDP in 2010 (Table 16). Only the public debt continued to rise gradually (Table 13). Even taking in consideration Portugal's Real GDP ${ }^{3}$, Table 9 shows that in 2010 Portugal registered $1.9 \%$ of GDP annual growth rate when compared to the $-3.0 \%$ occurred in 2009 . Thus, public spending associated with social citizenship rights did not play a direct role in the rise of public deficits and debt since the beginning of the 2008 financial crisis to the year 2010, when the need to sustain the rise of interest rates and achieve fiscal sustainability justified cuts and policy changes (through structural reforms) on different social citizenship rights - minimum income, unemployment insurance, pensions, health care, and education, in order to attenuate the pressures of financial markets and meet the EU demands for fiscal consolidation under the SGP rules. It was the rise of interest rates in 2010 that led to the rise in the costs for borrowing money in the financial markets, which in turn caused a rise in public deficits and debt, as demonstrated in Tables 12, 13, 24 and 25. Illustrations 2 and 3 also confirm the causal relation between the rise of interest rates and the rise of public deficit and debt.

Some findings were very much in line with the expectations. For example, income inequality and the poverty rate ${ }^{4}$ decreased from 2007 (prior to the financial crisis) to 2010. In 2007, Portugal's income inequality (Gini coefficient) ${ }^{5}$ was 0.361 and in 2010, it was 0.341 (Table 33). Similarly, Portugal registered 0.122 of poverty rate in 2007 and 0.110 in 2010 (Table 34). Thus, the rise of public social spending between 2008 and 2010 contributed decisively to mitigate the early effects of the 2008 financial crisis. The weakness of the Portuguese economy and its fiscal constraints suggest a direct relation between the decline of tax revenues and the rise of the

\footnotetext{
${ }^{3}$ The "OECD Real GDP forecast indicator" measures the $\%$ of Annual growth rate compared to previous year.

${ }^{4}$ The "OECD Poverty rate indicator" measures the total ratio of the number of people whose income falls below the poverty line; taken as half the median household income of the total population.

${ }^{5}$ The "Gini coefficient" ranges between 0 in the case of perfect equality and 1 in the case of perfect inequality.
} 
unemployment rate. Portugal's tax revenue declined from $31.82 \%$ of GDP in 2007 to $31.73 \%$ of GDP in 2008 and to $29.91 \%$ of GDP in 2009 . Only in 2010 did tax revenue increase to $30.41 \%$ of GDP (Table 15). The OECD data also show that the unemployment rate increased from $7.55 \%$ in 2008 (Table 5) to $10.77 \%$ in 2010 (Table 14). Therefore, the economic recession had a direct effect on the rise of unemployment and, consequently, on the household disposable income ${ }^{6}$ of Portuguese citizens which dropped severely from $1.09 \%$ in 2008 to $0.71 \%$ in 2010 (Table 8). Clearly, cash benefits of social citizenship rights - minimum income programs (RSI and CSI), unemployment insurance and old-age pensions - played an important role by easing the early effects of the 2008 financial crisis.

This research was able to identify the key targets of the structural reforms of the welfare state, planned or initiated, even before the 2008 financial crisis started, namely the labour market, public pensions and the public health care system. Unemployment insurance and old-age pensions were already a key target of the Portuguese authorities and of the EU policy agenda on competitiveness and fiscal sustainability. Similarly, the use of means-testing on social assistance programs was already a policy priority.

The analysis of the fourth SP between March 2010 and March 2011 - PEC I, PEC II, PEC III and PEC IV - and the MoU signed with the Troika (European Commission, ECB and IMF) along with its eleven review/updates between May 2011 and May 2014, allowed an answer to the second research question of this study: since the 2008 financial crisis, what was the impact of austerity on social citizenship rights caused by the measures adopted under the Stability

\footnotetext{
${ }^{6}$ The "OECD Household disposable income indicator" measures Net disposable income in terms of the percentage of annual growth rate.
} 
Programmes (between 2010 and 2011) and the Memorandum of Understanding (between May 2011 and May 2014)?

This research has shown that the fiscal consolidation adopted by EU member states under the rules of the SGP and of supra-national bodies like the European Commission, the ECB and the IMF place a high value on the process of welfare retrenchment. The 2008 financial crisis, and the new paradigm of austerity that followed, initiated a new stage in the process of welfare retrenchment in the EU. Interestingly, the 2010 European sovereign crisis was the impetus for pursuing a broad and deep structural adjustment in Southern European countries like Portugal. This case study on the impact of austerity measures on the changing nature of social citizenship rights in Portugal, between 2010 and 2014, shows the characteristics and the process of a new phase in the retrenchment of welfare capitalism in modern market societies, as a result, a new paradigm of austerity that unfolded following the 2008 financial crisis.

The findings of this research show that the politics of austerity officially began in March 2010 with the approval of PEC I (Stability Programme for 2010-2013), in line with the measures included in the State Budget for 2010 (DRE, 2010a; European Commission, 2010a). The austerity measures introduced by the socialist-led minority government were of a strong degree. They included changes in all the cash benefits of social citizenship rights - the GMI program (RSI), oldage pensions and unemployment insurance. For example, it was in 2010 that a comprehensive set of means-testing rules was introduced by Decree-Law No. 70/2010 of June 16, 2010 (Condição de Recursos) (DRE, 2010e). These mandatory means-testing rules were applied to all cash benefits, not only to the ones mentioned above, but also to disability benefits and family allowances. Income (as reported in the income taxes) and assets were introduced as the two main criteria to determine the eligibility and accessibility to several social assistance benefits in order 
to support only those most in need (DRE, 2010e). Such findings demonstrate that, even before Portugal was under the Troika's fiscal "dictatorship" as a result of the bailout program signed in May 2011, the retrenchment policy introduced in April 2010 by the Portuguese authorities represented a government approach that provided means-testing social citizenship rights. By changing the eligibility to access these cash benefits, the rights to such cash benefits of social citizenship became neither residual, nor encompassing. This approach views the market as the central means of allocation which may lead to high levels of income inequality and poverty. While the OECD indicator on income inequality shows that income inequality in Portugal dropped from 0.341 in 2010 to 0.337 in 2011 (Table 33), the total ratio of poverty rate increased in the same period from 0.110 to 0.114 (Table 34). How did these new means-testing rules play a role in the abrupt fall of the household disposable income, from $0.71 \%$ in 2010 to $-5.57 \%$ in 2011 (Table 8)? Certainly, the process of tightening the access to cash benefits resulted in significant gaps in social protection, particularly for households with two or more adults with some source of income. In this case, since means-testing was extended to all cash benefits of social citizenship rights, such rules were not only targeting benefits for the poor, but also for children, people with disabilities, and for people of the working class, such as family allowances, disability benefits and unemployment insurance. Table 19 shows that public social spending on family allowances in 2010 was $1.385 \%$ of GDP, when in 2009 , it had been $1.446 \%$ of GDP. Similarly, public social spending on disability benefits, either temporary or permanent, fell in 2010 to $1.926 \%$ of GDP compared to $2.006 \%$ of GDP registered in 2009 (OECD, 2018s).

In March 2010 PEC 1 (SP 1) introduced a series of austerity measures including spending cuts, tax hikes, a cap on the expenditure on the GMI (RSI) program and cuts to other support programs not directly associated with cash benefits. The cumulative effect of these measures 
shows how the 2008 financial crisis, and by extension the 2010 European sovereign debt crisis became a threat to the entitlements of social protection in Portugal (Illustration 1). Table 16 shows that social spending decreased in 2010 to $24.48 \%$ of GDP, when compared with $24.58 \%$ of GDP in 2009 (OECD, 20180). However, while Portugal adopted severe austerity measures throughout 2010, public expenditure (Table 22) increased from 50.223\% of GDP in 2009 (a year marked by a fiscal and economic stimulus) and to $51.819 \%$ of GDP in 2010 (a year of harsh cuts in the welfare state) (OECD, 2018u). This finding shows that the Portuguese government increased its public spending - perhaps as a result of the rise of interest rates paid in the financial markets to the investors in Portuguese public debt (Illustration 3) - while reducing the allocation of funding towards the welfare state, and also/thus restricted the access to cash benefits of social citizenship rights.

In September 2010, PEC III (SP III) was introduced and proposed further and deeper cuts, for the third time since March of that same year. The freezing of all public pensions in 2011 and a $20 \%$ cut in the expenditure on the GMI (RSI) program were proposed (DRE, 2010c). These findings demonstrate that the impact of austerity measures in Portugal during 2010 were very damaging to the rights of citizenship, and by extension to the entitlements of social citizenship. The aim for financial and economic stability helped lessen the obligations of the Portuguese authorities to fulfill the redistribution of a set of rights and resources of social citizenship to all citizens, regardless of their economic and social class.

In March 2011, and in line with the State Budget for 2011, PEC 4 (Stability Programme for 2011-2014) went even further by proposing further austerity measures on cash benefits of social citizenship rights (DRE, 2010d, GovPT, 2011a). However, the rejection of PEC IV by Portuguese lawmakers forced the socialist-led minority government to resign. 
The evidence demonstrated that, despite the political rejection of PEC IV, an austerity package such as the one proposed by PEC IV was the basis of the MoU later signed in 2011 between Portugal and the Troika (European Commission, ECB and IMF) in exchange for a $€ 78$ billion three-year bailout-loan. Despite their political anger the signing of the MoU demonstrated how citizens were in the end powerless in the decision-making process. Portugal's financial stability and market justice were put first. The demands of the EU and IMF for deep, conservative fiscal measures and several structural reforms, including to the welfare state, in exchange for a bailout program of $€ 78$ billion euros were accepted (GovPT, 2011b; IMF, 2011a).

The findings of the MoU and its eleven quarterly reviews showed that the Troika proposed cuts to social expenditure in all cash benefits and services (public health care and education) of social citizenship and structural reforms in the labour market, public pension systems (CGA and Social Security), public health care system (SNS), and education. These findings were in line with expectations because the reforms of the labour market, public pensions and health care system, were included by the Portuguese authorities in the Stability Programme 2007-2011, which was approved by the Portuguese parliament in December 2007 (European Commission, 2007). Thus, clearly the structural reforms of cash benefits - unemployment insurance and public pensions, included in the MoU signed between Portugal and the Troika in May 2011 - were already being planned as part of the process of retrenchment of the welfare state in Portugal. The analysis of the policy document of 2007 (Stability Programme 2007-2011) revealed that the aims of the socialistled government in 2007 were the same as those contained in the MoU signed with the Troika four years later in May 2011. The welfare state reforms, that were agreed by the Troika, were identified and planned before the 2008 financial crisis as part of the budgetary consolidation initiated in 2005 under the rules of the Stability and Growth Pact to reduce public deficits and debt of EU member 
states within the Eurozone. Looking back into that policy document (Stability Programme 20072011), structural factors, like the aging of the population, were being described to justify those reforms in order to achieve the sustainability of the welfare state. It was in 2007 that a new social security framework (Law No. 4/2007 of January 16) came into force (DRE, 2007a). Several measures on public pensions were introduced, including the new pension calculation formula referred to as the sustainability factor.

These findings in this research confirm that the 2008 financial crisis and the MoU signed between Portugal and the Troika in exchange for the bailout program were the justification to meet the end goal of pursuing structural reforms to the welfare state and which were so unpopular among citizens in Southern European countries like Portugal.

The combination of the Troika and IMF directives reinforced the policy approach and orientation undertaken in 2011 and throughout the thee-year bailout program. In addition, a new right-wing coalition government came into power in Portugal on June 21, 2011. The bold and ambitious agenda of fiscal consolidation, as IMF defined it, became easier, both politically and economically. The austerity measures initially included in the May $2011 \mathrm{MoU}$ demonstrated that the cash benefits of social citizenship rights were, from the beginning, a target in the cuts of public expenditure. For example, the freezing of public pensions until 2013 and the reduction of public pensions above $€ 1,500$ in 2012 (Table 26), an insurance-based cash benefit of social citizenship rights, shows that, under exceptional circumstances of a financial crisis like the one Portugal faced, pension earnings can be cut to a certain amount, depending on the degree of financial instability and the dynamics of decision making by national-based or supra-national institutions like the EU and the IMF. Monthly pension benefits are calculated when applicants meet the eligibility criteria at the time of retirement, taking into consideration their age, contributions to the pool, and duration 
of their contributions. These pension cuts represented a new paradigm for countries under financial intervention. The decision to reduce immediately public expenditures through old-age pensions breached, under the Portuguese Constitution, the contract signed between the state and its aging citizens under the Article 63, No. 1, 2 and 3 (TC, 2005).

Other findings of the MoU also showed that the budgetary consolidation was also applied to minimum income and unemployment insurance social citizenship programs. Cuts were not initially made on monthly benefits, but the reduction of expenditure was defined by placing new restrictions on the coverage and duration of the benefits or by changing the means-testing rules in order to tighten the eligibility criteria. This represented a combined effect of reducing public expenditure on these cash benefits in 2012 and 2013 and of changing the degree of decommodification of such benefits - eligibility, coverage of the risks, duration and generosity. Two examples of these changes are: (1) the new means-testing rules (Condição de Recursos) introduced by Decree-Law No. 133/2012 of June 27, 2012, which applied to all cash benefits of social citizenship - minimum income (RSI) program, unemployment insurance (including maternity/paternity and adoption leaves), and survivors' pensions (DRE, 2012d, 2012e); (2) a new amendment to the Unemployment Insurance Act through Decree-Law No. 64/2012 of March 15, 2012 which introduced three key measures on the retrenchment side (DRE, 2012b).

Following the austerity measures introduced by PEC I (SP I) in March 2010, the changes proposed by the MoU, which entered into force in the first semester of 2012, were very damaging to the entitlements of social citizenship rights of the most vulnerable - the poor and the unemployed. The cumulative effect of these austerity measures, cuts and restrictions also affected directly three vulnerable groups - children, older adults and people with disabilities. While this study, supported by OECD data, cannot fully determine the degree of the impact of these austerity 
measures on such populations, Portugal's household disposable income indicator provides an account of such impact in 2011 and 2012. In those years, the household disposable income dropped sharply to $-5.57 \%$ in 2011 , while it slightly increased to $-4.80 \%$ in 2012 (Table 8 ). Considering that the unemployment rate rose sharply to $12.68 \%$ in 2011 and to $15.53 \%$ in 2012 (Table 14), these measures certainly produced a severe impact on poverty levels as shown on Table 34 . In 2011, the ratio of poverty rate increased to 0.114 and in 2012 to 0.129 (OECD, 2018x). An unexpected finding was that income inequality decreased from 0.341 in 2010 to 0.337 in 2011 and in 2012 (Table 33). A possible explanation for such results can be found in the boost made by the Portuguese authorities to labour market policies like job training for people exiting from unemployment benefits or on social assistance (RSI program). As I mentioned earlier, a stimulus package of active labour policies was launched supported by EU funding. Programs like Estimulo 2012, Vida Ativa and Impulso Jovem were created (European Commission, 2012e, p. 67). This explains the results of Table 21 that show that Portugal's public spending on labour markets increased to $2.190 \%$ of GDP in 2012 and to $2.230 \%$ of GDP in 2013 . The same expenditure in 2011 represented 1.950\% of GDP (OECD, 2018t). However, the growth of the actual unemployment resulting in a higher unemployment rate in 2011 and 2012 forced the Portuguese authorities to spend more on unemployment benefits, increasing from 1.194\% of GDP in 2011 to $1.540 \%$ of GDP in 2012 and $1.608 \%$ of GDP in 2013 (Table 18). Similarly, expenditure on family benefits increased from 1.207\% of GDP in 2011 to $1.236 \%$ of GDP in 2012 (Table 19). Other factors and policy measures including lower income family tax exemptions and changes to income tax regulations not explored by this research further reinforce the explanation for the reduction and stabilization of income inequality in 2012 and 2013. 
In terms of old-age pensions, some measures proposed and adopted by the Portuguese authorities throughout the duration of the three-year bailout program were ruled unconstitutional by the TC, i.e., suspension of the thirteenth and fourteenth monthly bonus over $€ 1100$, and penalization of monthly pensions between $€ 600$ and $€ 1100$ (on average and in a progressive way) in one of the two monthly bonuses (TC, 2012, 2013a, 2013b, 2014). However, the payment of the fourteenth monthly pension bonus was spread out over the twelve monthly payments. Despite the TC rulings against the cuts to public pensions proposed in the State Budgets of 2012, 2013 and 2014, permanent and more long-term measures related to public pensions were approved. Two findings demonstrate that, in 2012, Decree-Law No. 85-A/2012 of April 5, 2012 suspended the special regime on old-age pensions for early retirement (DRE, 2012c). Likewise, in 2013, DecreeLaw No. 167-E/2013 of December 31, 2013 introduced several changes to old-age pensions, such as a new calculation formula tied to the sustainability factor to determine the age of retirement 65 year of age plus the number of months determined by the sustainability factor (DRE, 2013b). These policy change to old-age pensions demonstrated the government's commitment to pursue structural reforms of Portugal's public pension system, planned since 2005-2007, and agreed with the Troika in the MoU. Despite the introduction of these measures, public pension spending increased consistently after the 2008 financial crisis. In 2011, it represented 12.67\% of GDP, in $201213.00 \%$ of GDP, and in $201313.95 \%$ of GDP (Table 17). This can be explained by the medium- to long-term effect of some measures. It also reflects the effect of the TC rulings during the three-year bailout program. The arguments offered by the right-wing coalition government in power since June 2011 were that public pensions had to be cut during the bailout program in order to meet the public deficit target of $-3 \%$ of GDP agreed with the Troika. Nevertheless, findings of this research demonstrated that, the entitlements of social citizenship rights to the cash payments 
of public pensions, protected under the Portuguese Constitution, were met or not fully violated (TC, 2005). On the contrary, the criteria eligibility to access retirement and the generosity of pensions was affected by freezing payments, by suspending supplements or by cancelling the accumulation of pensions through means-testing.

Analysis of the year 2014, while not very representative since the MoU ended on May 18 of that year, shows that Portugal's public deficit was -7.17\% of GDP, and even in 2012 and 2013, when the Portuguese authorities implemented severe cuts to public spending (welfare state programs included), the public deficit was $-5.66 \%$ of GDP in 2012 and $-4.84 \%$ of GDP in 2013 (Table 12). While taking into consideration the unfavourable rulings of the TC on measures over public pensions, unemployment insurance and illness benefits, Table 15 shows that tax revenues increased significantly from $31.78 \%$ of GDP in 2012 to $34.07 \%$ in 2013 and to $34.26 \%$ in 2013 . The fiscal-adjustment program between 2011 and 2014 included severe tax hikes on personal income, VAT, property, and capital gains; however, the public deficit did not reach the $-3 \%$ of GDP. Lastly, a surprising finding was that Portugal's public debt increased sharply during the three-year bailout program, from 104.1\% of GDP in 2010 (that is, before the signature of the MoU), to $107.8 \%$ of GDP in $2011,137.1 \%$ of GDP in 2012 and 141\% of GDP in 2013. In May 2014, when the MoU bailout program ended, the public deficit reached 151.4\% of GDP (Table 13). While the public debt increased between 2011 and 2014, the long-term interest rates decreased significantly in 2012 from $10.5 \%$ to $3.8 \%$ in 2014 (Table 25 ). This was one of the main arguments for justifying the adoption of austerity measures in March 2010 (PEC I), which culminated with the request by Portugal for an international bailout program to stabilize its banking system and the public finances. 
Overall, the findings of this research show that the MoU budgetary consolidation adopted between 2011 and 2014 was supported by fiscal-structural measures to control public expenditure. This research demonstrates that, while severe cuts were applied on public expenditure on social citizenship rights particularly on cash benefits - minimum income program (RSI), unemployment insurance and old-age pensions - the main focus of the actions proposed by the Troika and by the Portuguese authorities was to carry out structural reforms in the labour market policies, particularly on unemployment insurance, and on public pensions.

\section{Examining key findings with reference to the literature}

\section{The 2008 financial crisis in context}

A wide body of literature on political economy has focused on the characteristics and dynamics of capitalism that are associated with the politics of the neoliberal state since the 1980s in advanced capitalist societies. Understanding capitalism and how the State ensures an adequate standard of living for its citizens through the entitlements and redistribution of social citizenship rights is crucial, not only for social workers, but for a broad range of decision makers. The 2008 financial crisis set a new paradigm in the process of retrenchment of the welfare state since the early 1980s. The first step of this research was to see how the characteristics and dynamics of capitalism affected the nature of social citizenship rights translated through the public provision of programs and services of social citizenship, defined in Chapter II. For example, as discussed in the Introduction, the politics of monetary stabilization undertaken in the early 1980s by the Reagan administration in the US and by the Thatcher government in the UK represented the beginning of the era of austerity, during which it was believed that public debt had to be solved by deep spending 
cuts to the social safety net (Blyth, 2013; Harvey, 2010a; Streeck, 2013, 2014). But how do the politics of monetary stabilization initiated in the 1980s relate to the 2010-2011 European debt crisis, and consequently, with the spike of public deficit and debt which occurred in Portugal between 2008-2010? The monetary crisis like the one that began with the US "subprime mortgage crisis" generated a spiral effect on the credit and banking system. Harvey (2010a) has shown that one of the main principles that emerged in the 1980s was that "the state power should protect financial institutions at all costs" (Harvey, 2010a, p. 10). This key principle of neoliberal theory explains how the 2008 financial crisis led to the European sovereign debt crisis in 2010-2011. The protection of the irrationalities of capitalism was seen of primary importance by the EU and Portuguese authorities when the crisis erupted (Blyth, 2013). The OECD data on Portugal's public deficit and debt, highlighted in this chapter, showed a spike increase in public deficit from $-3.77 \%$ of GDP in 2008 to $-11.17 \%$ of GDP in 2010 , and on public debt from $82.8 \%$ of GDP in 2008 to $104.1 \%$ of GDP in 2010. The causes of the rise of Portugal's public deficit and debt in this short period of time were explained by Blyth (2013), Crouch (2011) and Streeck (2013, 2014). The rise of public deficit and debt in Europe occurred because European governments, including Portugal's, decided to bail out and recapitalize their banks, turning private debt into public debt (Blyth, 2013). This generated the 2010-2011 European debt crisis (Blyth, 2013). Findings also showed that the rise of public deficit and debt in Portugal, in 2010 for example, occurred because a growing share of the budget was to pay interest to the creditors in financial markets (Blyth, 2013; Streeck \& Mertens, 2013).

The findings of the evolution of public deficit and debt in Portugal, between 2007-2011, were congruent with Streeck's thesis of the politics of the "consolidation state" (Streeck, 2014). Governments turned to debt as a way to finance their public spending, or what Crouch (2011) 
defined as "Privatized Keynesianism". Streeck's (2014) thesis confirmed why Portugal can be classified as a debt state. One of the main characteristics of the debt state is fiscal consolidation as a result of covering public expenditure through borrowing from financial markets since tax revenues are not enough to cover public expenditure (Crouch, 2011; Streeck, 2014).

\section{The political economy of austerity in Portugal}

The recipe of austerity measures in Portugal started in 2007 with the submissions of the Stability Programme 2007-2011. Such a recipe was originally made by the Treaty of Maastricht in 1992 through several economic and monetary rules, known as the "Maastricht criteria" (or "convergence criteria"). The amendment to the Treaty of Maastricht by the Treaty of Amsterdam, signed on October 2, 1997, and in force after May 1, 1999, reinforced such a recipe by constitutionalizing sound fiscal policies and budgetary discipline through the SGP, formally adopted in July 7, 1997, following the approval of a resolution at the European Council meeting in Amsterdam in June 17, 1997 (Eur-Lex, 1997b, 1997c). The SGP was further strengthened by the "Six-Pack" (2011), the "European Stability Mechanism" (2012), the "Two-Pack" (2013), and the "Treaty on Stability, Coordination and Governance" (2013). The introduction of these regulations and instruments by aiming to consolidate the public finances of EU member states neutralized domestic politics in favour of international agreements and regulatory regimes (Streeck, 2014). Such rules became a path forward for the liberalization of European capitalism, which forced participating EU member states to adopt a variety of pro-market reforms (Streeck, 2014). 
Findings demonstrate that Portugal's policy agenda and budget expenditure have been hostages of such fiscal policies and budgetary discipline since 2005 as a result of the excessive deficit procedure enforced between 2005 and 2007. With the 2008 financial crisis, Portugal's fiscal and economic weaknesses were exposed by the imposition of severe budgetary constraints on Eurozone members states and never before experienced in the history of the EU (Blyth, 2013; Piketty, 2014).

This study investigated how the new policy paradigm of prioritizing financial markets over citizens changed the nature of social citizenship rights. The analysis of PEC I, II, III and IV (between 2010 and 2011) and of the MoU (2011-2014) showed that the annual submission of Stability Programmes by Portugal and the MoU were embedded in Friedman's politics of monetarism and in German ordoliberal austerity approaches (Blyth, 2013; Friedman, 1962; Piketty, 2014).

The signing of the MoU between Portugal and the Troika (composed of the European Commission, the ECB and the IMF) culminated a process of increased austerity measures beginning in 2010 and lasting until the end of the bailout program in May 2014. Findings showed that cutting public expenditure to promote growth was not successful (Blyth, 2013; Lapavitsas et al., 2012). OECD data demonstrated that Portugal's Real GDP forecast, household disposable income and unemployment rate started falling between 2010 and 2011, precisely when the austerity recipe began to be implemented.

The measures agreed upon and adopted by the Portuguese authorities in the MoU and throughout the three-year bailout program were consistent with those described in the literature cuts to wages in the public sector, reduction of public spending, and raising of taxes. Structural reforms adopted throughout the crisis included greater labour market flexibility, the introduction 
of pension limiting conditions, and the privatization of state-owned companies and services (Blyth, 2013; Lapavitsas et al., 2012; Schafer \& Streeck, 2013; Streeck \& Mertens, 2013). However, what was surprising in the findings was that despite the enormous fiscal and economic adjustment made by Portugal between 2010 and 2014, public debt increased consistently and the measures adopted did not reduce overall public social spending. The MoU exposed the dynamics and contradictions of capitalism: while the most vulnerable and the working class were asked to pay their share, creditors and private investors profited from the Portuguese debt (Ferguson et al., 2002; Gough, 1979; Streeck, 2014).

\section{The retrenchment of social citizenship rights under austerity}

The process of retrenchment of the welfare state embodies a complex set of historical, ideological, economic and fiscal factors. While such a process has been explored through a wide variety of literature, in this research I have proposed in Chapter II (Table 1) a set of selected variables that reflect the key retrenchment construct components explored by Esping-Andersen (1990), Ferguson et al. (2018), Gilbert (2013); Marshall (1950) and Pierson (2001). The findings of this research were then focused on cash benefits of social citizenship rights - minimum income (RSI), unemployment insurance and old-age pensions - by taking into consideration those variables and components related to social spending, eligibility criteria, withdraw (dismantling or privatization) and restrictions (Table 1) (Esping-Andersen, 1990; Ferguson et al., 2018; Gilbert, 2013; Marshall, 1950; Pierson, 2001).

The cuts to public social expenditure and the changes to the conditions of eligibility to access the minimum income (RSI) program, unemployment insurance and old-age pensions were 
used consistently since the approval of PEC I (SP I) in 2010 to the end of the MoU in May 2014. Findings revealed that the Portuguese authorities either proposed or adopted austerity measures for the purpose of reducing public deficit and addressing structural factors like the aging of the population and the sustainability of the social security system. The austerity measures included reducing expenditures on public pensions and introducing changes in the eligibility criteria for cash benefits (Gilbert, 2013). For example, the measures adopted to deal with unemployment insurance were justified as necessary to promote competitiveness in the labour market. However, these measures were introduced in the context of high unemployment and the reduction of household disposable income. The state used the 2008 financial crisis to pursue a recommodification of needs by deeply reversing the nature and the degree of commodification of those cash benefits (Esping-Andersen, 1990, 1999; Pierson, 2001). This represented a new stage for reversing the nature of social citizenship rights and the degree of decommodification of social program benefits in Portugal (Esping-Andersen, 1990, 1999). The retreat of the Portuguese welfare state under the politics of austerity represented a new paradigm shift for welfare capitalism and pushed the rights of social citizenship into a far-reaching and very deep retrenchment process (Ferguson et al., 2018; Gilbert, 2013; Pierson, 2001). Findings confirmed that Southern European countries like Portugal, despite being under a fiscal adjustment, were forced to adopt cuts to cash benefits, introduce tight means-testing rules on cash benefits, push for lower wages, adopt labour market flexibility, promote competitiveness and privatize certain areas of public social services (Esping-Andersen, 1990, 1999; Ferguson et al., 2002; Gilbert, 2013; Mishra, 1993, 1999).

The process of retrenchment under austerity also contributed to reinforcing the inequalities of class and income (Marshall, 1950; Moscovitch, 1981). The severity of the austerity measures redistribution on the different cash benefits of social citizenship undermined one of the most 
distinctive forms of equality, its economic dimension. Findings showed that austerity measures directly affected access to and the distribution of material resources of income through the different cash benefits of social citizenship rights, and therefore severely affected economic equality (Cohen, 1997, 2011; Marshall, 1950; Moscovitch, 1981). Although cuts and changes introduced by the Portuguese authorities aimed to reduce public social spending on those cash benefits, the effects of the crisis and impact of the measures adopted affected even more deeply the equality of status promoted by the rights of social citizenship through the agency of the state (Marshall, 1950 Miller, 1995; White, 2007).

\section{Study contribution}

Some key findings have emerged from this research. This study offers new contributions to social work, social policy and political economy. It establishes a comprehensive framework for defining the nature of the rights of social citizenship in $21^{\text {st }}$ century capitalist market economies. It details the degree and the impact of the politics of austerity adopted in Portugal between 2010 and 2014. It provides an account of the austerity measures adopted in Portugal and the effect of those measures on the cash benefits of social citizenship rights - minimum income (social assistance), unemployment insurance and old-age pensions. Finally, it offers new policy directions and reflections for future research.

This study suggests that EU policies of balanced budgets that entrenched lower public deficits into Portugal's policy making undermined the constitutional principles of social citizenship centred on the fulfilment of a set of state-guaranteed social and economic provisions. The austerity measures, either proposed or fully adopted by the Portuguese authorities between 
2010 and 2014, resonate under certain assumptions and economic beliefs that do not serve the interests of the most vulnerable.

This study demonstrates that austerity policies and the measures they imposed on the public provision of cash benefits of social citizenship rights lead to increased levels of conditionality. In times of financial and economic crisis, the nature of social citizenship rights, whatever it might be, should not be changed since it reduces the degree of decommodification and coverage of such benefits against the risks created by the market.

This study also shows that, in the context of a financial crisis, neoliberal policies consider or pursue structural reforms on social assistance and public insurance-based programs. In doing so, governments and international institutions like the European Commission and the IMF are keen to propose and adopt permanent changes, either in the eligibility to access those cash benefits, or with restrictions that change the coverage, the duration and generosity of such cash benefits. With regards to the cuts to the expenditure on cash benefits, the contractual principles of public insurance - unemployment and old-age pensions - can be violated. National governments and international institutions (European Commission and IMF) can also consider cuts to pension wages due or to unemployment insurance benefits in payment.

This study also calls into question the use of means-testing for cash benefits of social citizenship rights which then contributes further to class inequality. Means-testing targets specific groups of a population and diminishes the degree of decommodification of the benefit, leading to social and income inequality and consequently significant gaps in social protection. Findings of this dissertation also suggest that changing means-testing rules during a period of financial crisis marked by growing levels of unemployment, poverty and income inequality pushes out more people in need to charitable organizations and food banks. 
Finally, this study contributes to the literature by detailing the process and degree of welfare retrenchment under the paradigm of austerity following the 2008 financial crisis.

\section{Evaluation of the study}

This dissertation in social work uses a structural approach to social work. For this reason, the study was undertaken by using specific theoretical and methodological approaches. It was congruent with Marshall's citizenship framework and Esping-Andersen's approach on welfare provision and redistribution (explored in Chapter I).

A structural approach to social work was chosen because it provides a methodologicaltheoretical approach to understanding the dynamics of capitalism and to bring to light the contradictions that underpin the process of retrenchment of welfare capitalism in modern market societies, under the paradigm of austerity following the 2008 financial crisis (Duarte, 2017).

Deciding on the research design for this study was particularly challenging and took a considerable amount of time. During the early stages, I decided that conducting case study research would be congruent with the critical approach selected because it would offer an in-depth analysis of the problem. I also chose to delimit the study's scope by deciding to focus on the case study of Portugal since it represented one of the EU member states that was under the Troika's bailout program following the 2008 financial crisis. I thought that this case study met two important criteria for case study selection. First, it is a critical case study of the politics of austerity implemented through an international bailout program. This dissertation offered the opportunity to study what actually happened to one country over time, as a result of the politics of austerity and their implementation. Second, it is a representative case in the EU and the Eurozone, because 
it represented other similar cases within the EU where even more severe forms of retrenchment of social citizenship rights under the paradigm of austerity have occurred (Blaxter et al., 2010; Matthews \& Ross, 2010).

It became clear that the data collected on the impacts and outcomes of austerity measures in Portugal were pointing to the annual Stability Programmes (PEC I, II, II and IV) approved by the Portuguese authorities between 2010 and 2011 and to the Memorandum of Understanding $(\mathrm{MoU})$ signed between Portugal and the Troika (composed of the European Commission, the ECB and the IMF), and then reviewed and updated by eleven quarterly reviews between September 2011 and May 2014.

In order to flesh out the identification of austerity measures proposed and/or adopted on social citizenship rights, I used different methods for data collection and analysis of policy documents, i.e., four Stability Programmes (PEC I, II, III and IV), the MoU, and its eleven quarterly reviews. Portuguese legislation like the State Budgets (2011-2014), the Portuguese Constitution (seventh revision), and the policy amendments introduced to cash benefits were also analyzed. To my research questions on the impact of austerity measures, I decided to add selected indicators of OECD secondary data on Portugal.

Finally, the technique used for collecting data from the policy documents and legislation mentioned above was through "analytical memo writing", a technique to organize the researcher's ideas on a paper for later reflection and analytic insight (Maxwell, 2005; Neuman, 2011). The "analytical memos" were the primary technique to track and organize the data collection and analysis of the policy documents and reports. This technique helped me to interpret, evaluate and ask critical questions about the purpose and degree of the austerity measures on cash benefits of social citizenship rights proposed and/or adopted in Portugal between 2010-2014. 
It is also appreciated that other approaches, both qualitative and quantitative, could be used. Positivist approaches perhaps could have offered more rational and objective critiques of certain measures and welfare state dimensions. Another limitation of this study relates to the external validity of single-case studies. The process of data selection can also be identified as a validity threat, because such data can fit the researcher's thesis and framework. An analysis of government accounts could have identified more precisely the real impact of the cuts and changes adopted in each one of the three social policy areas. Finally, it would have been interesting to include a sample of policy makers, union representatives and lawmakers across the political spectrum. A citizens' perspective could also have been taken into account.

\section{Recommendations}

In twenty-first century capitalist societies, inequality and poverty levels can only be undone by strengthening the degree of decommodification of social citizenship rights., which means providing a continuum from pure-market logic to publicly funded welfare programs and services. Cash benefits derived from social citizenship provide the baseline for a minimum threshold to achieve and/or maintain a minimum standard of living.

The conceptual Marshallian framework on social citizenship rights developed in Chapters I and II is therefore the foundation for defining a vision of society built on mitigating the class conflict caused by capitalism (Briggs, 1961; Marshall, 1950, 1970). Marshall's concern with the inequalities of capitalism led him to propose a mechanism of welfare provision to balance and stabilize class struggle in democratic, capitalist societies (George \& Wilding, 1985). 
The EU has a long-standing commitment to the protection of social citizenship rights. Since the 1951 Treaty of Paris, social security law has been a fundamental pillar of the EU integration process. In 1958, references to social provisions were included in the founding regulations of the EEC. Presently, the European Social Charter, the European Code for Social Security, and its Protocol guarantee the rights to social protection and welfare in the EU, and European norms for social security coverage and minimum levels of social protection in the areas of unemployment benefits and old-age pensions. The revised European Code for Social Security signed in 1990 in Rome has not entered into force, because it needs the ratification of two EU member states. To date, the Netherlands remains as the only signatory member state (Council of Europe [CoE], 2018a). Thus, the original European Code for Social Security signed in Strasbourg in 1964 remains in force since its implementation in 1968 (CoE, 2018b). The revision of the European Social Charter in 1996 has added rights to the original charter of 1961, in particular the right to protection against poverty and social exclusion (CoE, 2018c, 2018d; Eur-Lex, 2011a).

While this study focuses on the impact of the politics of austerity on the cash benefits of social citizenship rights in Portugal between 2010 and 2014, it went beyond by theorizing about the nature of social citizenship rights and the importance of public welfare provision in twentyfirst century capitalist societies. The 2008 financial crisis and the politics of austerity that followed across the EU were very damaging to the entitlements and public provision of social citizenship rights. The findings of this case study on Portugal can contribute to ground the impact of austerity measures and the cumulative effect of policy changes on the selected cash benefits of social citizenship rights that have pushed the process of retrenchment of the welfare state to another stage of social and economic inequalities. Monitoring such impact and measuring change in government's role in the welfare state, regardless of whether or not those changes relate directly 
with fiscal constraints imposed by international institutions like the European Commission and the IMF, can have a significant impact on how decision makers and citizens, at both national and European levels, think about the nature and importance of public provision of social citizenship rights.

Undoubtedly, the 2008 financial crisis brought new challenges to welfare states in Europe and to those who sell their labour power - the working class. In addition, those most vulnerable children, people with disabilities and the elderly - were also severely affected.

So, what can be done about the redistribution of cash benefits - minimum income (GMI/RSI), unemployment insurance and old-age pensions? The findings showed that, for a more egalitarian redistribution of cash benefits in EU member states within the Eurozone (EMU) like Portugal and other Southern European Countries, new policy directions need to be taken on income redistribution and taxation since questions of public debt, sustainability of public expenditure, inflation, budgetary consolidation and unemployment, will continue to arise. Therefore, I will offer policy directions and reflections for future research that speak to the national context of Portugal, but also offer solutions oriented towards the needs of all European member states who share the Euro as a common currency.

\section{Directions for policy}

The debates about the future of the social dimension in Europe offer an opportunity to ground new policy directions and research. The European Pillar of Social Rights outlines, in its Chapter III, the principles of social protection and inclusion. Unemployment benefits, minimum income and old-age income and pensions are the three principles that speak to the findings and 
policy directions of this study (European Commission, 2017b, 2018b). Delivering these three pillars embodies the maximization of the principles of equality, fairness and social justice through higher levels of material allocation of income and resources.

Following the announcement in September 2017, the European Commission presented on March 13, 2018, a legislative proposal for the creation of the European Labour Authority (ELA) to strengthen the implementation of the European Pillar of Social Rights (European Commission, 2018c, 2018d). It represents a step forward in the applicability of the Turin process launched at the High-level Conference on the European Social Charter which occurred in Turin, Italy on October 17-18, 2014 (CoE, 2018e). On June 21, 2018, the EU Council agreed on a general approach to revise the regulations on coordination of social security systems (EU Council, 2018).

A European redistributive function of cash benefits for member states in the Eurozone must be considered. Findings in this study demonstrated that labour market policies (for example, unemployment insurance) and public pension systems are a major concern and priority for EU institutions. Sustainability factors, the higher expenditure on public pensions in Portugal and other Southern European countries and the growing number of precarious jobs, which in return bring more cycles of higher levels of unemployment, justify a new comprehensive system of redistribution. The recent steps undertaken by the European Commission and the EU Council offer grounds to support the creation of a unified European pension scheme. The creation of the new ELA and the implementation of the European Pillar of Social Rights represent the opportunity for such a move. A European insurance mechanism for insurance-based public cash benefits - oldage pensions and unemployment insurance - can contribute to addressing sustainability and expenditure factors justified by the Troika (European Commission, ECB and IMF) to conduct structural reforms on Portugal's public pension system and labour market policies. The transfer of 
insurance-based redistributive mechanisms like old-age pension and unemployment insurance to the EU level can also contribute to creating a common and more egalitarian policy framework not exposed to cyclical risks of fiscal consolidation, drop of tax revenues, higher unemployment, and the aging of the population. Additionally, consideration must be given to the taxation system (Beblavý, Marconi \& Maselli, 2017). Considering that EU member states may oppose to transferring their national taxation systems to the EU level for going against EU federalism and consequently concerns of losing sovereignty, income taxation, either proportional (flat-tax) or progressive can be used to finance such European insurance mechanism for unemployment benefits and old-age pensions. As an alternative, a proportional percentage of countries' GDP can be used to finance this European redistributive mechanism for cash benefits. For example, the former can follow Canada's policy approach on income taxation and contributions to unemployment insurance and old-age pensions, where contributions are paid to the federal government which them manages and redistributes the benefits to the eligible beneficiaries in all the provinces. The latter, would create a modern and progressive form of financing unemployment premiums and pension contributions based on GDP's economic growth of member states. EU member states with stronger economies will contribute a higher share to the proposed European insurance mechanism. In this way, member states in the EMU are freed from the pressure of public deficit and debt, but also address the scope of the problem, even before they consider policy solutions (cuts, changes and restrictions), to fix debt burdens.

In 2017, the European Commission proposed the regulation for the creation of a PanEuropean Personal Pension Product (PEPP). Although the initiative contributes to create a PanEuropean framework for pensions, such framework is not yet intended to replace or combine with the existing national personal pension schemes (European Commission, 2017c; Eur-Lex, 2017). 
In a commentary about the European Commission's proposal, the European Fund and Asset Management Association (EFAMA) highlights some of the benefits of that proposal (EFAMA, 2017). Whether or not these private financial pension products are "worthy" and complementary to the existing national public pension schemes is debatable (Piketty, 2014). EFAMA is a longtime advocate of creating a single EU-wide pension system (EFAMA, 2005). These proposals are capitalized pension plans.

Instead, I argue for a European pay-as-you-go (PAYGO) scheme similar to the existing national public pension schemes where contributions are deducted from workers' wages to pay public pensions based on a principle of integrational solidarity (Piketty, 2014). The PAYGO schemes are rooted in the conceptual framework of social citizenship rights which aim to stabilize or even modify the negative impact of market forces, such as income inequality and poverty upon retirement. Piketty (2014, p. 487) explains that, PAYGO's "rate of return is by definition equal to the growth rate of the economy: the contributions available to pay tomorrow's retirees will rise as average wages rise." Piketty (2014) observes that arguments in favour of capitalized schemes have major flaws. He further notes that "the return on capital is in practice extremely volatile" (Piketty, 2014, p. 488). Therefore, in a situation of a financial crisis like the one that started in 2008 and lasted for almost five years in Europe, the PAYGO pension scheme continues to be the one that offers the right of entitlement to a guaranteed income cash benefit (Briggs, 1961; EspingAndersen, 1990; Marshall, 1950, 1970).

Thus, the proposed European redistributive function for insurance-based cash benefits unemployment benefits and old-age pensions - can be integrated under the new ELA and is in line with the principles on social protection and inclusion of the European Pillar of Social Rights (European Commission, 2018c, 2018d). The ELA or other agencies should then have 
representative offices in each member state who join the European redistributive function and offer national and local support to the citizens of the member state.

\section{Future research}

As mentioned above, this study identified Marshall's conceptual framework of social citizenship rights as the best to conceptualize the nature, public provision and ideals of social citizenship rights. Findings about the process of retrenchment of the welfare state under the paradigm of austerity showed that minimum income (RSI) and unemployment insurance benefits suffered from multiple policy changes between 2010 and 2014. Poverty levels and income inequality increased while the degree of decommodification of such benefits went in the opposite direction. New means-testing rules (Condição de Recursos) and restrictions on the eligibility to access the GMI (RSI) program and unemployment benefits, on the coverage, duration and generosity were introduced. Despite the aim of budgetary consolidation, enforcing tight meanstesting rules should not have been considered. Rather the need was for more flexible means-testing rules or to suspend means-testing, even temporarily, to access the GMI (RSI) program. Thus, consideration must be given to the effectiveness of means-testing rules, either in Portugal during the crisis, or in a broader context, in the EU. Must means-testing be applied to all cash benefits like Portugal did between 2010 and 2014? Additionally, the taxation of cash benefits, particularly during the bailout program in Portugal, may have created a double burden in the impact of austerity measures on these benefits.

This study has provided an understanding of the nature of social citizenship rights as well as guidance about the different forms of public welfare provision and redistribution in order to 
unpack and explore the components and dimensions of process of retrenchment of the welfare state. It accomplished this by proposing a list of variables to identify the types welfare retrenchment as a result of the politics of austerity. It has also identified, in Chapter I, the three criteria to assess the "degree of equalization" achieved through the rights of social citizenship proposed by Marshall (1950) and the three dimensions to define the nature of welfare provision and its forms of redistribution established by Esping-Andersen (1990, 1999). But how do we conceptualize and define the measurement of social citizenship rights on cash benefits? As this type of measurement has not been established until now, such conceptualization for measuring social citizenship rights must be considered. These findings on the impact of austerity measures on social citizenship rights have many implications for scholarship and policy development.

The importance of understanding what in fact is the degree of decommodification of cash benefits of social citizenship rights and how are they tackling the different inequalities of class and income is embedded in the nature and definition of social citizenship rights that defines what constitutes the State's fundamental obligations in the maximization of social equality, fairness and social justice for all in modern capitalist market societies, in particular the access to and the distribution of material resources of income.

A measurement index can then be developed to assess the outcomes of government actions to fulfill the rights of social citizenship. For example, the index can be used to measure the decommodification of material resources of income as cash transfers through programs of minimum income, unemployment insurance and old-age pensions. 


\section{References}

Amini, B. (2015). A chronology of the European sovereign debt crisis. Socialism and Democracy, 29(3), 166-178. doi:10.1080/08854300.2015.1101950

Androff, D. K. (2016). Practicing rights: Human rights-based approaches to social work practice. New York, London: Routledge.

Arcanjo, M. (2011). Welfare state regimes and reforms: A classification of ten European countries between 1990 and 2006. Social Policy and Society, 10(2), 139-150. doi:10.1017/S1474746410000497

Arts, W. A., \& Gelissen, J. (2006). Three worlds of welfare capitalism or more? A state-of-the-art report. In C. Pierson \& F. G. Castles (Eds.), The welfare state reader, $2^{\text {nd }}$ ed. (pp. 175-197). Cambridge: Polity.

Arts, W. A., \& Gelissen, J. (2010). Models of the welfare state. In F. G. Castles, S. Leibfried, J. Lewis, H. Obinger \& C. Pierson (Eds.), The Oxford handbook of the welfare state (pp. 569583). Oxford: Oxford University Press.

Association Européenne pour la défense des Droits de l'Homme (2009). The community charter of fundamental social rights of workers - December, 9th 1989. Brussels: Belgium. Retrieved from $\quad$ http://www.aedh.eu/en/the-community-charter-of-fundamental-social-rights-ofworkers-december-9th-1989/

Association Européenne pour la défense des Droits de l'Homme (2017). Social rights: Is a social Europe really in the way? Brussels: Belgium. Retrieved from http://www.aedh.eu/en/socialrights-is-a-social-europe-really-in-the-way/\# ftnref3 
Baer, W., \& Leite, A. N. (2003). The economy of Portugal within the European Union: 19902002. Quarterly Review of Economics and Finance, 43(5), 738-754. doi:10.1016/S10629769(03)00047-4

Baerg, N. R., \& Hallerberg, M. (2016). Explaining instability in the stability and growth pact: The contribution of member state power and Euroscepticism to the euro crisis. Comparative Political Studies, 49(7), 968-1009. doi:10.1177/0010414016633230

Baggott, R. (2016). Health care. In P. Alcock, T. Haux, M. May \& S. Wright (Eds.), The student's companion to social policy (5 ${ }^{\text {th }}$ ed.) (pp. 351-357). Hoboken, NJ; Chichester, UK: John Wiley \& Sons.

Barreto. A. (1995). Portugal na periferia do centro: mudança social, 1960 a 1996. Análise Social, $134(4), 841-855$.

Bastien, C. (1993). Marxism, labour movement and culture in Portugal. Estudos de Economia, XIII (2), 145-179.

Batista, I., \& Cabrita, J. (2009). Minimum income schemes in Europe. A study of national policies. Retrieved from http://www.ec.europa.eu/social/BlobServlet?docId=9039\&langId=en

Beblavý, M., Marconi, G., \& Maselli, I. (2017). A European unemployment benefit scheme: the rationale and the challenges ahead. European Commission, Directorate-General for Employment, Social Affairs and Inclusion - Directorate Employment \& Social Governance. Retrieved from https://publications.europa.eu/s/jKwY

Beveridge, W. (1942). Social insurance and allied services. London, Great Britain: Parliament House of Commons.

Bieling, H. (2006). EMU, financial integration and global economic governance. Review of International Political Economy, 13(3), 420-448. doi:10.1080/09692290600769286 
Birmingham, D. (2003). A concise history of Portugal ( $2^{\text {nd }}$ ed.). Cambridge, UK: Cambridge University Press.

Blaxter, L., Hughes, C., \& Tight, M. (2010). How to research (4th ed.). Maidenhead: Open University Press.

Blyth, M. (2013). Austerity: The history of a dangerous idea. Oxford; New York: Oxford University Press.

Braga de Macedo, J. (2003). Portugal's European integration: The limits of external pressure. In F. Monteiro, J. Tavares, M. Galtzer and A. Cardoso (Eds.), Portugal: Strategic options in a European context (pp. 61-97). Lanham, Boulder, New York, Oxford: Lexington Books.

Branco, F. (2001). O Rendimento mínimo garantido como direito de cidadania em Portugal. Intervenção Social, 23/24, 303-337.

Branco, F. (2003). A Pensão Social como primeiro pilar de uma rede universal de assistência social em Portugal. Intervenção Social, 28, 157-175.

Branco, R. (2017). Entre Bismarck e Beveridge: sociedade civil e estado providência em Portugal (1960-2011). Análise Social, vol. LII (3. ), 224, 534-558.

Briggs, A. (1961). The welfare state in historical perspective. Archives Europeennes De Sociologie, 2(2), 221-258. doi:10.1017/S0003975600000412

Brodie, J. (2008). The social in social citizenship. In E. Isin (Eds.), Recasting the Social in Citizenship, (pp. 20-43). Toronto: University Toronto Press.

Bruneau, T. C., Jalali, C. \& Colino, C. (Eds.) (2015). Sustainable governance indicators: 2015 Portugal Report. Gütersloh, Germany: Bertelsmann Stiftung. Retrieved from http://www.sgi-network.org/docs/2015/country/SGI2015 Portugal.pdf 
Burkitt, B., \& Baimbridge, M. (1994). The Maastricht treaty's impact on the welfare state. Critical Social Policy, 14(42), 100-111. doi:10.1177/026101839401404208

Cabral, R., \& Soromenho-Marques, V. (2014). Portugal: 40 years of democracy and integration in the European Union. Brussels: The Heinrich-Böll-Stiftung European Union. Retrieved from https://eu.boell.org/en/2014/03/25/portugal-40-years-democracy-and-integrationeuropean-union

Cardoso, S., Santos, M. H., Baptista, M. I., \& Clemente, S. (2012). Estado e políticas sociais sobre a velhice em Portugal (1990-2008). Análise Social, 204, XLVII (3), 606-630.

Castles, F. G. (2010). The English-speaking countries. In F. G. Castles, S. Leibfried, J. Lewis, H. Obinger \& C. Pierson (Eds.), The Oxford handbook of the welfare state (pp. 630-642). Oxford: Oxford University Press.

Clarke, J., \& Newman, J. (2012). The alchemy of austerity. Critical Social Policy, 32(3), 299-319. doi: $10.1177 / 0261018312444405$

Cohen, G. A. (1997). Back to socialist basics. In J. Frank (Ed.), Equality (pp. 29-47). London: Institute for Public Policy Research.

Cohen, G. A. (2011). On the currency of egalitarian justice, and other essays in political philosophy. Princeton, N.J: Princeton University Press.

Council of Europe (2018a). Details of treaty No.139: European code of social security (Revised). Retrieved from https://www.coe.int/en/web/conventions/full-list/-/conventions/treaty/139

Council of Europe (2018b). Details of treaty No.48: European code of social security. Retrieved from https://www.coe.int/en/web/conventions/full-list/-/conventions/treaty/048

Council of Europe (2018c). Details of treaty No.163: European social charter (revised). Retrieved from https://www.coe.int/en/web/conventions/full-list/-/conventions/treaty/163 
Council of Europe (2018d). Details of treaty No.035: European social charter. Retrieved from https://www.coe.int/en/web/conventions/full-list/-/conventions/treaty/035

Council of Europe (2018e). The Turin process for the European social charter. Retrieved from https://www.coe.int/en/web/turin-european-social-charter/turin-process

Crosland, A. (1961). The future of socialism. London: Jonathan Cape.

Crouch, C. (2011). The strange non-death of neoliberalism. Malden, MA; Cambridge, UK: Polity Press.

Diário da República Eletrónico (1984). Law n. 148/1984 of June 26. Retrieved from https://dre.pt/web/guest/pesquisa//search/382393/details/normal?q=Lei + n. $\%$ C2\%BA $\% 2028 \% 2 F 84$

Diário da República Eletrónico (1996). Law n. 149/1996 of June 29. Retrieved from http://data.dre.pt/eli/lei/19-a/1996/06/29/p/dre/pt/html

Diário da República Eletrónico (1997). Law n. 196/1997 of July 31. Retrieved from http://data.dre.pt/eli/dec-lei/196/1997/07/31/p/dre/pt/html

Diário da República Eletrónico (2007a). Law n. 4/2007 of January 16. Retrieved from http://data.dre.pt/eli/lei/4/2007/01/16/p/dre/pt/html

Diário da República Eletrónico (2007b). Law n. 53/2007 of August 31. Retrieved from http://data.dre.pt/eli/lei/52/2007/08/31/p/dre/pt/html

Diário da República Eletrónico (2010a). Law n. 3-B/2010 of April 28. Retrieved from http://data.dre.pt/eli/lei/3-b/2010/04/28/p/dre/pt/html

Diário da República Eletrónico (2010b). Law n. 12-A/2010 of June 30. Retrieved from http://data.dre.pt/eli/lei/12-a/2010/06/30/p/dre/pt/html 
Diário da República Eletrónico (2010c). Decree-Law n. 137/2010 of December 28. Retrieved from http://data.dre.pt/eli/dec-lei/137/2010/12/28/p/dre/pt/html

Diário da República Eletrónico (2010d). Law n. 55-A/2010 of December 31. Retrieved from https://dre.pt/web/guest/pesquisa/-/search/344942/details/maximized

Diário da República Eletrónico (2010e). Decree-Law n. 70/2010 of June 16. Retrieved from http://data.dre.pt/eli/dec-lei/70/2010/06/16/p/dre/pt/html

Diário da República Eletrónico (2011). Law n. 64-B/2011 of December 30. Retrieved from https://dre.pt/pesquisa/-/search/243769/details/maximized

Diário da República Eletrónico (2012a). Law n. 66-B/2012 of December 31. Retrieved from http://data.dre.pt/eli/lei/66-b/2012/12/31/p/dre/pt/html

Diário da República Eletrónico (2012b). Decree-Law n. 64/2012 of March 15. Retrieved from http://data.dre.pt/eli/dec-lei/64/2012/03/15/p/dre/pt/html

Diário da República Eletrónico (2012c). Decree-Law n. 85-A/2012 of April 5. Retrieved from http://data.dre.pt/eli/dec-lei/85-a/2012/04/05/p/dre/pt/html

Diário da República Eletrónico (2012d). Decree-Law n. 133/2012 of June 27. Retrieved from http://data.dre.pt/eli/dec-lei/133/2012/06/27/p/dre/pt/html

Diário da República Eletrónico (2012e). Ministerial Order n. 257/2012 of August 27. Retrieved from http://data.dre.pt/eli/port/257/2012/08/27/p/dre/pt/html

Diário da República Eletrónico (2013a). Law n. 83-C/2013 of December 31. Retrieved from http://data.dre.pt/eli/lei/83-c/2013/12/31/p/dre/pt/html

Diário da República Eletrónico (2013b). Decree-Law n. 167-E/2013 of December 31. Retrieved from http://data.dre.pt/eli/dec-lei/167-e/2013/12/31/p/dre/pt/html

Dean, H. (2012). Social policy (2nd ed.). Cambridge: Polity. 
Dean, H. (2013). The translation of needs into rights: Reconceptualising social citizenship as a global phenomenon. International Journal of Social Welfare, 22 (1), n/a. doi:10.1111/ijsw.12032

De La Porte, C., \& Heins, E. (2015). A new era of European integration governance of labour market and social policy since the sovereign debt crisis. Comparative European Politics, 13(1), 8-28. doi:10.1057/cep.2014.39

Diamond, P., \& Giddens, A. (2005). The new egalitarianism. In A. Giddens \& P. Diamond (Eds.), The new egalitarianism (pp. 101-119). Malden, MA; Cambridge, UK: Polity.

Drover, G., \& Moscovitch, A. (1981). Inequality and social welfare. In A. Moscovitch \& G. Drover (Eds.), Inequality: Essays on the political economy of social welfare (pp. 3-23). Toronto: University of Toronto Press.

Duarte, F. (2017). Reshaping political ideology in social work: A critical perspective. Aotearoa New Zealand Social Work, 29(2), 34-44. doi:10.11157/anzswj-vol29iss2id282

Duca, V. J. (2013). Subprime mortgage crisis 2007-2010. Federal Reserve History. Retrieved from https://www.federalreservehistory.org/essays/subprime_mortgage_crisis

EFAMA (2005). The European personal pension system account. Retrieved from https://www.efama.org/Publications/Public/Long-

\section{$\underline{\text { Term_Savings_and_Pension_Steering_Committee/eppareport.pdf }}$}

EFAMA (2017, September 27). EFAMA's comments on the European Commission's proposal for a regulation on a pan-European personal pension product (PEPP). Retrieved from https://www.efama.org/Publications/Public/Long-

Term_Savings and Pension_Steering_Committee/EFAMA_Position_Paper_PEPP_Propos al.pdf 
Esping-Andersen, G. (1990). The three worlds of welfare capitalism. Cambridge: Polity Press.

Esping-Andersen, G. (1999). Social foundations of postindustrial economies. New York: Oxford University Press.

Eur-Lex (1978). Draft statement by the Community delegation at the first meeting of the Conference at deputy level (Brussels, 1 December 1978) on the procedure for and organisation of the accession negotiations with Portugal (submitted by the Commission to the Council). European Community COM/1978/0489 final, 1-11. Retrieved from https://eurlex.europa.eu/legalcontent/EN/TXT/PDF/?uri=CELEX:51978PC0489\&qid=1542428153448\&from=EN

Eur-Lex (1979). Commission communication to the Council on the negotiations between the Community and Portugal for the conclusion of a supplementary protocol between the European Economic Community and Portugal. European Community COM (79) 556 final. 1-50. $\quad$ Retrieved from https://eur-lex.europa.eu/legalcontent/EN/TXT/PDF/?uri=CELEX:51979DC0556\&qid=1542566996617\&from=EN

Eur-Lex (1992a). Treaty of Maastricht on European union. Retrieved from http://eurlex.europa.eu/legal-content/EN/TXT/?uri=LEGISSUM:xy0026

Eur-Lex (1992b). Treaty on European union. Official Journal of the European Communities, 191 (1), 1-112

Retrieved from http://eur-lex.europa.eu/legalcontent/EN/TXT/PDF/?uri=CELEX:11992M/TXT\&from=EN

Eur-Lex (1997a). Treaty of Amsterdam amending the treaty on European union, the treaties establishing the European communities and certain related acts - Final Act. Official Journal of the European Communities, C 340 (40), 1-144. Retrieved from http://www.europarl.europa.eu/topics/treaty/pdf/amst-en.pdf 
Eur-Lex (1997b). Resolution of the European council on the stability and growth pact. Official Journal of the European Communities, C 236 (1), 1-2. Retrieved form http://eurlex.europa.eu/legal-content/EN/TXT/PDF/?uri=CELEX:31997Y0802(01)\&from=EN

Eur-Lex (1997c). Council regulation (EC) No 1466/97 of 7 July 1997 on the strengthening of the surveillance of budgetary positions and the surveillance and coordination of economic policies. Official Journal of the European Communities L 209 (1), 1-5. Retrieved from http://data.europa.eu/eli/reg/1997/1466/2011-12-13

Eur-Lex (1997d). Council regulation (EC) $1467 / 97$ on speeding up and clarifying the implementation of the excessive deficit procedure (the corrective arm of the stability and growth pact). Official Journal of the European Communities L 209 (1), 1-16. Retrieved from http://eur-lex.europa.eu/legal-content/EN/TXT/PDF/?uri=CELEX:01997R1467-

\section{$\underline{20111213 \& \text { from }=\mathrm{EN}}$}

Eur-Lex (2005a). Council regulation (EC) No 1055/2005 of 27 June 2005 amending regulation (EC) No $1466 / 97$ on the strengthening of the surveillance of budgetary positions and the surveillance and coordination of economic policies. Official Journal of the European Communities L 174 (1), 1-4. Retrieved from http://data.europa.eu/eli/reg/2005/1055/oj

Eur-Lex (2005b). Council regulation (EC) No 1056/2005 of 27 June 2005 amending regulation (EC) No 1467/97 on speeding up and clarifying the implementation of the excessive deficit procedure. Official Journal of the European Communities L 174 (5), 1-5. Retrieved from http://data.europa.eu/eli/reg/2005/1056/oj 
Eur-Lex (2008a). Consolidated versions of the Treaty on European union and the treaty on the functioning of the European union. Official Journal of the European Communities C 115, 1-338. Retrieved from https://eur-lex.europa.eu/legalcontent/EN/TXT/?uri=uriserv:OJ.C .2008.115.01.0001.01.ENG\&toc=OJ:C:2008:115:TO $\underline{\mathrm{C}}$

Eur-Lex (2008b). Consolidated version of the treaty on the functioning of the European union part three: Union policies and internal actions - title viii: economic and monetary policy chapter 1: Economic policy - article 121 (ex article 99 TEC). Official Journal of the European Communities C 115, 97-98. Retrieved from https://eur-lex.europa.eu/legalcontent/EN/ALL/?uri=CELEX:12008E121

Eur-Lex (2008c). Consolidated version of the treaty on the functioning of the European union part three: Union policies and internal actions - title viii: economic and monetary policy chapter 1: Economic policy - article 126 (ex article 104 TEC). Official Journal of the European Communities C 115, 99-102. Retrieved from https://eur-lex.europa.eu/legalcontent/EN/ALL/?uri=CELEX:12008E121

Eur-Lex (2008d). Protocol (No 12) on the excessive deficit procedure. Official Journal of the European Communities C 115, 279-280. Retrieved from https://eur-lex.europa.eu/legalcontent/EN/ALL/?uri=CELEX:12008M/PRO/12

Eur-Lex (2008e). Council opinion of 4 March 2008 on the updated stability programme of Portugal, 2007-2011. Official Journal of the European Communities C 73, 6-9. Retrieved from https://eur-lex.europa.eu/legalcontent/EN/TXT/PDF/?uri=CELEX:32008A0319(02)\&from=EN 
Eur-Lex (2008f). Communication from the commission to the European council - A European economic recovery plan. EC Communication COM/2008/0800 final, 1-19. Retrieved from https://eur-lex.europa.eu/legalcontent/EN/TXT/PDF/?uri=CELEX:52008DC0800\&from=EN

Eur-Lex (2009). Council opinion of 10 March 2009 on the updated stability programme of Portugal, 2008-2011. Official Journal of the European Communities C 71, 8-12. Retrieved from https://eur-lex.europa.eu/legalcontent/EN/TXT/PDF/?uri=CELEX:32009A0325(01)\&from=EN

Eur-Lex (2010a). The single European act. Retrieved from http://eur-lex.europa.eu/legalcontent/EN/TXT/?uri=LEGISSUM:xy0027

Eur-Lex (2010b). Council Opinion on the updated stability programme of Portugal, 2009-2013. Official Journal of the European Communities C 144, 6-11. Retrieved from https://eurlex.europa.eu/legal-content/EN/TXT/PDF/?uri=CELEX:32010A0603(02)\&from=EN

Eur-Lex (2010c). Communication from the commission to the European parliament, the council, the European central bank, the European economic and social committee and the committee of the regions enhancing economic policy coordination for stability, growth and jobs - Tools for stronger EU economic governance. EC Communication COM/2010/0367 final, 1-22. $\begin{array}{lll}\text { Retrieved } & \text { from } & \text { https://eur-lex.europa.eu/legal- }\end{array}$ content/EN/TXT/PDF/?uri=CELEX:52010DC0367\&qid=1534042974285\&from=EN

Eur-Lex (2010d). Council regulation (EU) No 407/2010 of 11 May 2010 establishing a European financial stabilisation mechanism. Official Journal of the European Communities L 118, 195-198. Retrieved from https://eur-lex.europa.eu/legalcontent/EN/TXT/PDF/?uri=CELEX:32010R0407\&from=EN 
Eur-Lex (2010e). Communication from the commission to the council and the economic and financial committee on the European financial stabilisation mechanism. EC Communication COM/2010/0713 final, 1-10. Retrieved from https://eur-lex.europa.eu/legalcontent/EN/TXT/PDF/?uri=CELEX:52010DC0713\&qid=1534454763237\&from=EN

Eur-Lex (2011a). Community charter of fundamental social rights of workers. Retrieved from http://eur-lex.europa.eu/legal-content/EN/ALL/?uri=URISERV:c10107

Eur-Lex (2011b). Regulation (EU) No 1173/2011 of the European parliament and of the council of 16 November 2011 on the effective enforcement of budgetary surveillance in the euro area. Official Journal of the European Communities L 306, 1-7 Retrieved from http://data.europa.eu/eli/reg/2011/1173/oj

Eur-Lex (2011c). Regulation (EU) No 1174/2011 of the European parliament and of the council of 16 November 2011 on enforcement measures to correct excessive macroeconomic imbalances in the euro area. Official Journal of the European Communities L 306, 8-11. Retrieved from http://data.europa.eu/eli/reg/2011/1174/oj

Eur-Lex (2011d). Regulation (EU) No 1175/2011 of the European parliament and of the council of 16 November 2011 amending council regulation (EC) No 1466/97 on the strengthening of the surveillance of budgetary positions and the surveillance and coordination of economic policies. Official Journal of the European Communities L 306, 12-24. Retrieved from http://data.europa.eu/eli/reg/2011/1175/oj

Eur-Lex (2011e). Regulation (EU) No 1176/2011 of the European parliament and of the council of 16 November 2011 on the prevention and correction of macroeconomic imbalances. Official Journal of the European Communities L 306, 25-32. Retrieved from http://data.europa.eu/eli/reg/2011/1176/oj 
Eur-Lex (2011f). Council regulation (EU) No 1177/2011 of 8 November 2011 amending regulation (EC) No 1467/97 on speeding up and clarifying the implementation of the excessive deficit procedure. Official Journal of the European Communities L 306, 33-40. Retrieved from http://data.europa.eu/eli/reg/2011/1177/oj

Eur-Lex (2011g). Council directive 2011/85/EU of 8 November 2011 on requirements for budgetary frameworks of the member states. Official Journal of the European Communities L 306 (5), 41-47. Retrieved from http://data.europa.eu/eli/dir/2011/85/oj

Eur-Lex (2011h). Recommendation for a council recommendation on the national reform programme 2011 of Portugal [and delivering a council opinion on the updated stability programme of Portugal, 2011-2014]. EC Communication SEC/2011/0814 final, 1-4.

Retrieved from https://eur-lex.europa.eu/legalcontent/EN/TXT/PDF/?uri=CELEX:52011SC0814\&from=EN

Eur-Lex (2011i). Council recommendation of 12 July 2011 on the national reform programme 2011 of Portugal. Official Journal of the European Communities C 216 (1), 1-2. Retrieved from https://eur-lex.europa.eu/legalcontent/EN/TXT/PDF/?uri=CELEX:32011H0722(01)\&from=EN

Eur-Lex (2012a). Charter of fundamental rights of the European union. Official Journal of the European Communities C 326, 391-407. Retrieved from https://eur-lex.europa.eu/legalcontent/EN/TXT/PDF/?uri=CELEX:12012P/TXT\&from=EN 
Eur-Lex (2013a). Regulation (EU) No 472/2013 of the European parliament and of the council of 21 May 2013 on the strengthening of economic and budgetary surveillance of member states in the euro area experiencing or threatened with serious difficulties with respect to their financial stability. Official Journal of the European Communities L 140, 1-10. Retrieved from http://data.europa.eu/eli/reg/2013/472/oj

Eur-Lex (2013b). Regulation (EU) No 473/2013 of the European parliament and of the council of 21 May 2013 on common provisions for monitoring and assessing draft budgetary plans and ensuring the correction of excessive deficit of the Member States in the euro area. Official Journal of the European Communities $L$ 140, 11-23. Retrieved from http://data.europa.eu/eli/reg/2013/473/oj

Eur-Lex (2014). Communication from the commission to the European parliament, the council, the European central bank, the European economic and social committee and the committee of the regions economic governance review report on the application of regulations $(E U) n^{\circ}$ 1173/2011, 1174/2011, 1175/2011, 1176/2011, 1177/2011, 472/2013 and 473/2013. EC Communication COM/2014/0905 final, 1-22. Retrieved from https://eur-lex.europa.eu/legalcontent/EN/TXT/PDF/?uri=CELEX:52014DC0905\&from=EN

Eur-Lex (2015). Communication from the commission to the European parliament, the council, the European central bank, the economic and social committee, the committee of the regions and the European investment bank making the best use of the flexibility within the existing rules of the stability and growth pact. EC Communication COM/2015/012 final, 1-21. Retrieved from https://eur-lex.europa.eu/legalcontent/EN/TXT/PDF/?uri=CELEX:52015DC0012\&from=EN 
Eur-Lex (2017). Proposal for a regulation of the European parliament and of the council on a panEuropean personal pension product (PEPP). EC Communication COM/2017/0343 final 2017/0143 (COD), 1-79. Retrieved from https://eur-lex.europa.eu/legalcontent/EN/TXT/?uri=CELEX:52017PC0343

Eurofound (2011). Community charter of the fundamental social rights of workers. Retrieved from www.eurofound.europa.eu/observatories/eurwork/industrial-relationsdictionary/community-charter-of-the-fundamental-social-rights-of-workers

European Commission (2007). Portugal's stability and growth programme (2007-2011).

Retrieved

from

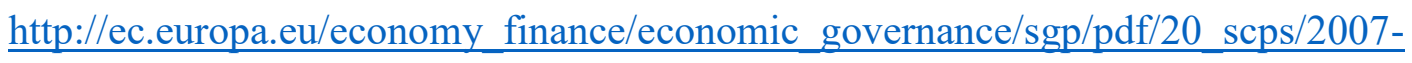

08/01_programme/2007-12-14_pt_sp_en.pdf

European Commission (2008a). Recommendation for a council opinion on the updated stability programme of Portugal, 2007-2011. $\quad$ Retrieved from http://ec.europa.eu/economy finance/economic_governance/sgp/pdf/20 scps/2007-

08/03_commission/2008-02-13_pt_recommendation_for_co_en.pdf

European Commission (2008b). Portugal macro-fiscal assessment: An analysis of the December 2007 update of the stability and growth programme. Retrieved from http://ec.europa.eu/economy_finance/economic_governance/sgp/pdf/20_scps/2007$\underline{08 / 02 \text { technical assessment/2008-02-27 pt ta en.pdf }}$

European Commission (2009a). Portugal's stability and growth programme (2008-2011).

Retrieved from http://ec.europa.eu/economy finance/economic_governance/sgp/pdf/20 scps/200809/01_programme/pt_2009-01-30_sp_en.pdf 
European Commission (2009b). Recommendation for a council opinion on the updated stability programme of Portugal, 2008-2011. Retrieved from http://ec.europa.eu/economy_finance/economic_governance/sgp/pdf/20_scps/200809/03_commission/pt_2009-02-25_recommendation_en.pdf

European Commission (2009c). Portugal macro-fiscal assessment: An analysis of the January 2009 update of the stability and growth programme. Retrieved from http://ec.europa.eu/economy_finance/economic_governance/sgp/pdf/20_scps/200809/02_technical_assessment/pt_2009-03-11_ta_en.pdf

European Commission (2010a). Portugal's stability and growth programme (2010-2013). Retrieved from http://ec.europa.eu/economy_finance/economic_governance/sgp/pdf/20_scps/200910/01_programme/pt_2010-03-29_sp_en.pdf

European Commission (2010b). Recommendation for a council opinion on the updated stability programme of Portugal, 2009-2013. Retrieved from http://ec.europa.eu/economy_finance/economic_governance/sgp/pdf/20_scps/200910/03_commission/2010-04-14_pt_recommendation_for_co_en.pdf

European Commission (2011a, April 6). Portugal requests activation of the financial support $\begin{array}{lllll}\text { mechanisms. } & E C & \text { Press } & \text { Release. } & \text { Retrieved }\end{array}$ http://ec.europa.eu/economy finance/articles/financial operations/2011-04-06portugal en.htm

European Commission (2011b, December 12). EU economic governance "six-pack" enters into force. EC Press Release MEMO/11/898. Retrieved from http://europa.eu/rapid/pressrelease MEMO-11-898_en.htm 
European Commission (2011c). Portugal 2020 - national reform programme. Retrieved from https://ec.europa.eu/info/sites/info/files/file_import/nrp_portugal_en_0.pdf

European Commission (2011d, April 8). Statement by the eurogroup and ECOFIN minister. EC Press Release MEMO/11/227. Retrieved from http://europa.eu/rapid/press-release_MEMO11-227 en.htm

European Commission (2011e). The economic adjustment programme for Portugal (European Economy, Occasional Papers 79). Brussels: European Commission. Retrieved from http://ec.europa.eu/economy_finance/publications/occasional_paper/2011/pdf/ocp79_en.pd $\underline{\mathrm{f}}$

European Commission (2011f). The economic adjustment programme for Portugal: first review summer 2011 (European Economy, Occasional Papers 83). Brussels: European Commission. Retrieved from http://ec.europa.eu/economy finance/publications/occasional paper/2011/pdf/ocp83 en.pd $\underline{\mathrm{f}}$

European Commission (2011g, August 12). Statement by the EC, ECB, and IMF on the first review mission to Portugal. EC Press Release MEMO/11/555. Retrieved from http://europa.eu/rapid/press-release_MEMO-11-555 en.htm

European Commission (2011h). The economic adjustment programme for Portugal: second review - autumn 2011 (European Economy, Occasional Papers 89). Brussels: European Commission. $\quad$ Retrieved from http://ec.europa.eu/economy_finance/publications/occasional paper/2011/pdf/ocp89 en.pd $\underline{\mathrm{f}}$ 
European Commission (2011i, November 16). Statement by the EC, ECB, and IMF on the second review mission to Portugal. EC Press Release MEMO/11/793. Retrieved from http://europa.eu/rapid/press-release_MEMO-11-793_en.htm

European Commission (2012a, February 1). Treaty on stability, coordination and governance in the economic and monetary union. EC Communication D/12/2. Retrieved from http://europa.eu/rapid/press-release DOC-12-2 en.htm

European Commission (2012b, June 20). Communication from the commission: Common principles on national fiscal correction mechanisms. EC Communication COM/2012/0342 final. $\quad$ Retrieved from https://eur-lex.europa.eu/legalcontent/EN/TXT/PDF/?uri=CELEX:52012DC0342\&from=EN

European Commission (2012c). The economic adjustment programme for Portugal: third review - winter 2011/2012. Brussels: European Commission. Retrieved from http://ec.europa.eu/economy finance/publications/occasional paper/2012/pdf/ocp95 en.pd $\underline{\mathrm{f}}$

European Commission (2012d, February 28). Statement by the EC, ECB, and IMF on the third review mission to Portugal. EC Press Release MEMO/12/142. Retrieved from http://europa.eu/rapid/press-release_MEMO-12-142_en.htm

European Commission (2012e). The economic adjustment programme for Portugal: fourth review - spring 2012 (European Economy, Occasional Papers 111). Brussels: European Commission. Retrieved from http://ec.europa.eu/economy_finance/publications/occasional_paper/2012/pdf/ocp111_en.p $\underline{\text { df }}$ 
European Commission (2012f, June 4). Statement by the EC, ECB, and IMF on the fourth review mission to Portugal. EC Press Release. Retrieved from http://ec.europa.eu/economy_finance/articles/financial_operations/2012-06-04portugal_en.htm

European Commission (2012g). The economic adjustment programme for Portugal: fifth review - summer 2012 (European Economy, Occasional Papers 117). Brussels: European Commission. Retrieved from http://ec.europa.eu/economy_finance/publications/occasional_paper/2012/pdf/ocp117_en.p $\underline{\mathrm{df}}$

European Commission (2012h, September 11). Statement by the EC, ECB, and IMF on the fifth review mission to Portugal. EC Press Release. Retrieved from http://europa.eu/rapid/pressrelease MEMO-12-663 en.htm

European Commission (2012i). The economic adjustment programme for Portugal: sixth review - autumn 2012 (European Economy, Occasional Papers 124). Brussels: European Commission. $\quad$ Retrieved from http://ec.europa.eu/economy finance/publications/occasional paper/2012/pdf/ocp124 en.p df

European Commission (2012j, November 12). Statement by the EC, ECB, and IMF on the sixth review mission to Portugal. EC Press Release. Retrieved from http://europa.eu/rapid/press$\underline{\text { release MEMO-12-879 en.htm }}$ 
European Commission (2013a, May 27). 'Two-Pack' enters into force, completing budgetary surveillance cycle and further improving economic governance for the euro area. EC press release MEMO/13/457. Retrieved from http://europa.eu/rapid/press-release_MEMO-13457 en.htm

European Commission (2013b, March 15). Statement by the EC, ECB, and IMF on the seventh review mission to Portugal. EC Press Release. Retrieved from http://europa.eu/rapid/pressrelease MEMO-13-226 en.htm

European Commission (2013c). The economic adjustment programme for Portugal: seventh review - winter 2012/2013 (European Economy, Occasional Papers 153). Brussels: $\begin{array}{lll}\text { European } & \text { Commission. } & \text { Retrieved }\end{array}$ http://ec.europa.eu/economy_finance/publications/occasional_paper/2013/pdf/ocp153_en.p df

European Commission (2013d, October 3). Statement by the EC, ECB, and IMF on the eight and ninth review mission to Portugal. EC Press Release. Retrieved from http://europa.eu/rapid/press-release_MEMO-13-850 en.htm

European Commission (2013e). The economic adjustment programme for Portugal: eighth and ninth review (European Economy, Occasional Papers 164). Brussels: European Commission.

Retrieved

from http://ec.europa.eu/economy finance/publications/occasional paper/2013/pdf/ocp164 en.p $\underline{\mathrm{df}}$

European Commission (2013f, December 16). Statement by the EC, ECB, and IMF on the tenth review mission to Portugal. EC Press Release. Retrieved from http://europa.eu/rapid/pressrelease_MEMO-13-1158_en.htm 
European Commission (2014a). The economic adjustment programme for Portugal: tenth review (European Economy, Occasional Papers 171). Brussels: European Commission. Retrieved from

http://ec.europa.eu/economy_finance/publications/occasional_paper/2014/pdf/ocp171_en.p $\underline{\mathrm{df}}$

European Commission (2014b, February 28). Statement by the EC, ECB, and IMF on the eleventh review mission to Portugal. EC Press Release. Retrieved from http://europa.eu/rapid/pressrelease STATEMENT-14-39 en.htm

European Commission (2014c). The economic adjustment programme for Portugal: eleventh review (European Economy, Occasional Papers 191). Brussels: European Commission. Retrieved from http://ec.europa.eu/economy_finance/publications/occasional_paper/2014/pdf/ocp191_en.p df

European Commission (2014d, May 2). Statement by the EC, ECB, and IMF on the twelfth review mission to Portugal. EC Press Release. Retrieved from http://europa.eu/rapid/pressrelease MEMO-14-329 en.htm

European Commission (2014e). The economic adjustment programme for Portugal. 2011-2014 (European Economy, Occasional Papers 202). Brussels: European Commission. Retrieved from

http://ec.europa.eu/economy finance/publications/occasional paper/2014/pdf/ocp202 en.p $\underline{\mathrm{df}}$

European Commission (2017a). Legal basis of the stability and growth pact. Retrieved from https://ec.europa.eu/info/node/4318 
European Commission (2017b). European pillar of social rights. Retrieved from https://ec.europa.eu/commission/sites/beta-political/files/social-summit-european-pillarsocial-rights-booklet en.pdf

European Commission $(2017 \mathrm{c})$. Commission proposal for a regulation on a pan-European $\begin{array}{llll}\text { personal pension } \quad \text { product } & \text { (PEPP). } & \text { Retrieved }\end{array}$ https://ec.europa.eu/info/publications/170629-personal-pension-products en

European Commission (2018a, August 10). Europe 2020 strategy. Retrieved from https://ec.europa.eu/info/business-economy-euro/economic-and-fiscal-policycoordination/eu-economic-governance-monitoring-prevention-correction/european$\underline{\text { semester/framework/europe-2020-strategy en }}$

European Commission (2018b). The European pillar of social rights in 20 principles. Retrieved from https://ec.europa.eu/commission/priorities/deeper-and-fairer-economic-and-monetary$\underline{\text { union/european-pillar-social-rights/european-pillar-social-rights-20-principles en }}$

European Commission (2018c, March 13). Commission adopts proposals for a European Labour Authority and for access to social protection. EC Press Release. Retrieved from http://europa.eu/rapid/press-release_IP-18-1624_en.htm

European Commission (2018d). European labour authority. Retrieved from http://ec.europa.eu/social/main.jsp?catId=1414\&langId=en

European Communities Commission (1978a). The Commission's opinion on Portugal's application for membership. Information Memo, P-56, 1-3. Retrieved from http://aei.pitt.edu/30675/1/P_56 78.pdf 
European Communities Commission (1978b). Opinion on Portuguese application for membership. transmitted to the Council by the Commission on 19 May 1978. COM (78) 220 final,1-50. Retrieved from http://aei.pitt.edu/966/1/enlargement_portugal_opinion.pdf

European Communities Commission (1979). Commission communication and recommendation to the Council on the negotiation of an agreement amending certain provisions of the agreement between the Community and Portugal. COM (79) 209 final, 1-21. Retrieved from http://aei.pitt.edu/32874/1/COM_(79)_209_final.pdf

European Council (2005, March 21). Improving the implementation of the stability and growth Pact - council report to the European council (ECOFIN Working Document). Brussels: ECOFIN. Retrieved from http://www.eu2005.lu/en/actualites/documents_travail/2005/03/21stab/stab.pdf

European Council (2011, May 17). Council approves aid to Portugal, sets out conditions. European $\begin{array}{lllll}\text { Council Press } & \text { Release } & \text { 10231/11. } & \text { Retrieved }\end{array}$ https://www.consilium.europa.eu/uedocs/cms_data/docs/pressdata/en/ecofin/122047.pdf

European Council (2018, March 21). Coordination of social security systems: Council agrees general approach. EU Council Press Release 371/18. Retrieved from https://www.consilium.europa.eu/en/press/press-releases/2018/06/21/coordination-ofsocial-security-systems-council-agrees-general-approach/

European Economic and Social Committee (2015). Towards a European minimum income. Retrieved from https://www.eesc.europa.eu/resources/docs/qe-02-13-510-en-c.pdf European Parliament (2018a). Developments up to the single European act. Retrieved from http://www.europarl.europa.eu/factsheets/en/sheet/2/developments-up-to-the-singleeuropean-act 
European Parliament (2018b). The Maastricht and Amsterdam treaties. Retrieved from http://www.europarl.europa.eu/factsheets/en/sheet/3/the-maastricht-and-amsterdam-treaties European Social Policy Network (2016). Minimum income schemes in Europe. Retrieved from http://www.ec.europa.eu/social/BlobServlet?docId=15304\&langId=en

European Stability Mechanism (2014, May 18). Portugal successfully exits EFSF programme. ESM Press Release. Retrieved from https://www.esm.europa.eu/press-releases/portugal$\underline{\text { successfully-exits-efsf-programme }}$

Evans, B. (2014). Social democracy in the new age of austerity. In D. Baines \& McBride (Eds.), Orchestrating austerity: impacts and resistance (pp. 79-90). Halifax \& Winnipeg: Fernwood Publishing.

Evers, A., \& Guillemard, A. M. (2013). Introduction: Marshall's concept of citizenship and the contemporary welfare reconfiguration. In A. Evers \& A. M. Guillemard (Eds.), Social policy and citizenship: The changing landscape (pp. 3-34). Oxford: Oxford University Press.

Ferguson, I. (2009). Where's the beef? A response to Gray and Webb's "The return of the political in social work." International Journal of Social Welfare, 18(2), 213-217. doi:10.1111/j.1468-2397.2009.00648.x

Ferguson, I., Ioakimidis, V., \& Lavalette, M. (2018). Global social work in a political context. Bristol: Policy Press.

Ferguson, I., Lavalette, M., \& Mooney, G. (2002). Rethinking welfare: A critical perspective. London: SAGE.

Ferreira, A. R., Carolo, D., Pereira, M. T., \& Silva, P. A. (2016). Fundamentos constitucionais da proteção social: Continuidades e ruturas. Sociologia, Problemas e Práticas, special number, pp. 71-97. doi:10.7458/SPP2016NE10351 
Ferreira, S. (2005). The past in the present: Portuguese social security reform. Social Policy and Society, 4(3), 331-338. doi:10.1017/S1474746405002484

Ferrera, M. (1996). The "southern model" of welfare in social Europe. Journal of European Social Policy, 6(1), 17-37. doi:10.1177/095892879600600102

Ferrera, M. (2010). The south European countries. In F. G. Castles, S. Leibfried, J. Lewis, H. Obinger \& C. Pierson (Eds.), The Oxford handbook of the welfare state (pp. 616-629). Oxford: Oxford University Press.

Ferrera, M. (2013). Liberal neo-welfarism: new perspectives for the European social model (OSE Paper Series, Opinion Paper No.14). Retrieved from http://www.ose.be/files/publication/OSEPaperSeries/Ferrera_2013_OpinionPaper14_Liber al_neowelferism.pdf

Frank, J. (1997). Introduction. In J. Frank (Ed.), Equality (pp. 1-10). London: Institute for Public Policy Research.

Fraser, N. (1989). Unruly practices: Power, discourse, and gender in contemporary social theory. Minneapolis: University of Minnesota Press.

Friedman, M. (1962). Capitalism and freedom. Chicago: University of Chicago Press.

G20 (2010). The G20 Toronto summit declaration. Retrieved from http://www.g20.utoronto.ca/2010/to-communique.html

George, V., \& Wilding, P. (1985). Ideology and social welfare. Boston, MA; London, UK: Routledge \& Kegan Paul.

Giddens, A. (1996). T.H. Marshall, the state and democracy. In Martin Bulmer \& Anthony M. Rees (Eds.), Citizenship today: The contemporary relevance of T.H. Marshall (pp. 65-80). London: UCL Press. 
Gilbert, N. (2013). Citizenship in the enabling state: the changing balance of rights and obligations. In A. Evers \& A. M. Guillemard (Eds.), Social policy and citizenship: The changing landscape (pp. 80-96). Oxford: Oxford University Press.

Gough, I. (1979). The political economy of the welfare state. London: Macmillan.

Govan, F. (2010, November 26). Portugal approves austerity measures. The Telegraph. Retrieved from https://www.telegraph.co.uk/finance/financialcrisis/8163146/Portugal-approvesausterity-measures.html

Government of Portugal (2011a). Stability and growth programme 2011-2014. Retrieved from https://www.parlamento.pt/OrcamentoEstado/Documents/pec/21032011PEC2011_2014.pdf

Government of Portugal (2011b). Letter of intent. Retrieved from https://www.portugal.gov.pt/media/371366/letter_of_intent_eu_20110313.pdf

Gray, M., \& Webb, S. A. (2013). Towards a 'new politics' of social work. In M. Gray \& S. A. Webb (Eds.), The new politics of social work. (pp. 3-20). New York, N.Y: Palgrave Macmillan.

Guillén, A., Álvarez, S., \& Adão e Silva, P. (2003). Redesigning the Spanish and Portuguese welfare states: The impact of accession into the European union. South European Society and Politics, 8(1-2), 231-268. doi:10.1080/13608740808539650

Harris, J. (2014). (Against) neoliberal social work. Critical and Radical Social Work, 2(1), 7-22. doi: https://doi.org/10.1332/204986014X13912564145528

Harvey, D. (2005). A brief history of neoliberalism. Oxford; New York: Oxford University Press. Harvey, D. (2010a) The enigma of capital: and the crises of capitalism. Oxford: Oxford University Press. 
Harvey, D. (2010b). A commentary on Marx's method. [Audio podcast]. Retrieved from http://havenscenter.wisc.edu/audio/david-harvey-commentary-marxs-method

Harvey, D. (2014). Seventeen contradictions and the end of capitalism. New York: Oxford University Press.

Hay, C., \& Wincott, D. (2012). The political economy of European welfare capitalism. Houndmills, Basingstoke, Hampshire: Palgrave Macmillan.

Hemerijck, A. (2002). The self-transformation of the European social model(s). In G. EspingAndersen, D. Gallie, A. Hemerijck \& J. Myles (Eds.), Why we need a new welfare state (pp. 173-214). Oxford: Oxford University Press.

Hemerijck, A. (2011). 21st Century welfare provision is more than the "social insurance state": A reply to Paul Pierson (ZeS-Arbeitspapier, No. 03/2011). Retrieved from https://www.econstor.eu/dspace/bitstream/10419/52138/1/67165358X.pdf

Ife, J. (2012). Human rights and social work: Towards rights-based practice ( $\left.3^{\text {rd }} \mathrm{ed}\right)$. Cambridge, New York: Cambridge University Press.

International Federation of Social Workers (2016). The role of social work in social protection systems: the universal right to social protection. Retrieved from http://ifsw.org/policies/the$\underline{\text { role-of-social-work-in-social-protection-systems-the-universal-right-to-social-protection }}$

International Labour Organization (2014). World social protection report 2014-15: Building economic recovery, inclusive development and social justice. Retrieved from https://www.ilo.org/wcmsp5/groups/public/---dgreports/--dcomm/documents/publication/wems_245201.pdf 
International Monetary Fund (2011a). Portugal: Letter of intent, memorandum of economic and financial policies, and technical memorandum of understanding. Retrieved from https://www.imf.org/external/np/loi/2011/prt/051711.pdf

International Monetary Fund (2011b, May 20). Press release: IMF executive board approves an $€ 26$ billion extended arrangement for Portugal. IMF Press Release No. 11/190. Retrieved from http://www.imf.org/en/News/Articles/2015/09/14/01/49/pr11190

International Monetary Fund (2011c). Portugal: request for a three-year arrangement under the extended fund facility (Country Report No. 11/127). Washington, D.C: International Monetary Fund. Retrieved from http:/www.imf.org/external/pubs/ft/scr/2011/cr11127.pdf

International Monetary Fund (2011d). Portugal: first review under the extended arrangement (Country Report No. 11/279). Washington, D.C: International Monetary Fund. Retrieved from http://www.imf.org/ /media/Websites/IMF/imported-full-textpdf/external/pubs/ft/scr/2011/ cr11279.ashx

International Monetary Fund (2011e, August 12). Press release: Statement by the EC, ECB, and IMF on the first review mission to Portugal. IMF Press Release N. 11/307. Retrieved from http://www.imf.org/en/News/Articles/2015/09/14/01/49/pr11307

International Monetary Fund (2011f). Portugal: second review under the extended arrangement (Country Report No. 11/363). Washington, D.C: International Monetary Fund. Retrieved from $\quad$ http://www.imf.org/ /media/Websites/IMF/imported-full-textpdf/external/pubs/ft/scr/2011/ cr11363.ashx

International Monetary Fund (2011g, November 16). Press release: Statement by the EC, ECB, and IMF on the second review mission to Portugal. IMF Press Release N. 11/416. Retrieved from http://www.imf.org/en/News/Articles/2015/09/14/01/49/pr11416 
International Monetary Fund (2012a). Portugal: third review under the extended arrangement and request for waiver of applicability of end-march performance criteria - staff report; staff statement; press release on the executive board discussion; and statement by the executive director for Portugal (Country Report No. 12/77). Washington, D.C: International Monetary Fund. Retrieved from http://www.imf.org/ /media/Websites/IMF/imported-full-textpdf/external/pubs/ft/scr/2012/_cr1277.ashx

International Monetary Fund (2012b, February 28). Press release: Statement by the EC, ECB, and IMF on the third review mission to Portugal. IMF Press Release N. 12/59. Retrieved from https://www.imf.org/en/News/Articles/2015/09/14/01/49/pr1259

International Monetary Fund (2012c). Portugal: fourth review under the extended arrangement and request for a waiver of applicability of end-June performance criteria - staff report; press release on the executive board discussion; and statement by the executive director for Portugal (Country Report No. 12/179). Washington, D.C: International Monetary Fund. Retrieved from http:/www.imf.org/ /media/Websites/IMF/imported-full-textpdf/external/pubs/ft/scr/2012/ cr12179.ashx

International Monetary Fund (2012d, June 4). Press release: Statement by the EC, ECB, and IMF on the fourth review mission to Portugal. IMF Press Release N. 12/203. Retrieved from http://www.imf.org/en/News/Articles/2015/09/14/01/49/pr12203

International Monetary Fund (2012e). Portugal: fifth review under the extended arrangement and request for waivers of applicability and non observance of end-September performance criteria: staff report; press release on the executive board discussion; and statement by the executive director for Portugal (Country Report No. 12/292). Washington, D.C: 
$\begin{array}{llll}\text { International } & \text { Monetary } & \text { Fund. } & \text { Retrieved }\end{array}$ http://www.imf.org/ /media/Websites/IMF/imported-full-textpdf/external/pubs/ft/scr/2012/_cr12292.ashx

International Monetary Fund (2012f, September 11). Press release: Statement by the EC, ECB, and IMF on the fifth review mission to Portugal. IMF Press Release N. 12/310. Retrieved from http://www.imf.org/en/News/Articles/2015/09/14/01/49/pr12310

International Monetary Fund (2013a). Portugal: 2012 article IV consultation and sixth review under the extended arrangement and request for waivers of applicability of end-December performance criteria - staff reports; (Country Report No. 13/18). Washington, D.C: $\begin{array}{llll}\text { International } & \text { Monetary } & \text { Fund. } & \text { Retrieved }\end{array}$ http://www.imf.org/ /media/Websites/IMF/imported-full-textpdf/external/pubs/ft/scr/2013/_cr1318.ashx

International Monetary Fund (2013b, January 16). Press release: Statement by the EC, ECB, and IMF on the sixth review mission to Portugal. IMF Press Release N. 13/14. Retrieved from http://www.imf.org/en/News/Articles/2015/09/14/01/49/pr1314

International Monetary Fund (2013c, March 15). Press release: Statement by the EC, ECB, and IMF on the seventh review mission to Portugal. IMF Press Release N. 13/78. Retrieved from https://www.imf.org/en/News/Articles/2015/09/14/01/49/pr1378

International Monetary Fund (2013d). Portugal: seventh review under the extended arrangement and request for modification of end-June performance criteria - staff report; press release on the executive board discussion; and statement by the executive director for Portugal (Country Report No. 13/160). Washington, D.C: International Monetary Fund. Retrieved 
from

http://www.imf.org/ /media/Websites/IMF/imported-full-text-

$\mathrm{pdf} / \mathrm{external} / \mathrm{pubs} / \mathrm{ft} / \mathrm{scr} / 2013 / \operatorname{cr} 13160$.ashx

International Monetary Fund (2013e). Portugal: eighth and ninth reviews under the extended arrangement and request for waivers of applicability of end-September performance criteria (Country Report No. 13/324). Washington, D.C: International Monetary Fund. Retrieved from http://www.imf.org/ /media/Websites/IMF/imported-full-textpdf/external/pubs/ft/scr/2013/_cr13324.ashx

International Monetary Fund (2013f, October 3). Press release: Statement by the EC, ECB, and IMF on the eight and ninth review mission to Portugal. IMF Press Release N. PR13/384. Retrieved from http://www.imf.org/en/News/Articles/2015/09/14/01/49/pr13384

International Monetary Fund (IMF) (2013g, December 16). Press release: Statement by the EC, ECB, and IMF on the tenth review mission to Portugal. IMF Press Release N. 13/512. Retrieved from http://www.imf.org/en/News/Articles/2015/09/14/01/49/pr13512

International Monetary Fund (2014a). Portugal: tenth review under the extended arrangement and request for waivers of applicability of end-December performance criteria (Country Report No. 14/56). Washington, D.C: International Monetary Fund. Retrieved from http://www.imf.org/ /media/Websites/IMF/imported-full-textpdf/external/pubs/ft/scr/2014/ cr1456.ashx

International Monetary Fund (2014b, February 28). Press release: Statement by the EC, ECB, and IMF on the eleventh review mission to Portugal. IMF Press Release N. 14/80. Retrieved from https://www.imf.org/en/News/Articles/2015/09/14/01/49/pr1480

International Monetary Fund (2014c). Portugal: eleventh review under the extended arrangement, and request for extension of the arrangement and waivers of applicability of end-march 
performance criteria (Country Report No. 14/102). Washington, D.C: International Monetary Fund. Retrieved from http://www.imf.org/ /media/Websites/IMF/imported-fulltext-pdf/external/pubs/ft/scr/2014/_cr14102.ashx

International Monetary Fund (2014d, May 2). Press release: Statement by the EC, ECB, and IMF on the twelfth review mission to Portugal. IMF Press Release N. 14/193. Retrieved from https://www.imf.org/en/News/Articles/2015/09/14/01/49/pr14193

International Monetary Fund (2014e, June 12). Press release: Statement by the EC, ECB, and IMF on Portugal. IMF Press Release N. 14/277. Retrieved from https://www.imf.org/en/News/Articles/2015/09/14/01/49/pr14277

International Monetary Fund (2017). Portugal fast facts. Retrieved from https://www.imf.org/external/np/exr/countryfacts/prt/

Instituto de Segurança Social (2015). Evolução do sistema de segurança social. Retrieved from http://www.seg-social.pt/evolucao-do-sistema-de-seguranca-social

Iverson, T. (2010). Democracy and capitalism. In F. G. Castles, S. Leibfried, J. Lewis, H. Obinger \& C. Pierson (Eds.), The Oxford handbook of the welfare state (pp. 183-195). Oxford: Oxford University Press.

Katrougalos, G., \& Lazaridis, G. (2003). Southern European welfare states: problems, challenges and prospects. Houndmills, Basingstoke, Hampshire: Palgrave Macmillan.

Keynes, J. M. (1936). The general theory of employment, interest and money. London: Macmillan. Kivisto, P., \& Faist, T. (2007). Citizenship: discourse, theory and transnational prospects. Oxford: Blackwell Publishing. 
Jepsen, M., \& Serrano Pascual, A. (2005). The European social model: An exercise in deconstruction. Journal of European Social Policy, 15(3), 231-245. $10.1177 / 0958928705054087$

Lane, P. R. (2012). The European sovereign debt crisis. The Journal of Economic Perspectives, 26(3), 49-67. doi:10.1257/jep.26.3.49

Lapavitsas, C., Kaltenbrunner, A., Lindo, D., Michell, J., Painceira, J. P., Pires, E., ... \& Teles, N. (2012). Begar thyself and thy neighbour. In C. Lapavitsas (Eds.), Crisis in the eurozone (pp. 1-74). London: Verso Books.

Laursen, F. (2012). The treaty of Maastricht. In E. Jones, A. Menon \& S. Weatherill (Eds.), The Oxford handbook of the European Union (pp. 121-134). Oxford: Oxford University Press.

Leonard, P. (1997). Post-modern welfare state. London: Sage.

Lister, R. (2003). Citizenship: Feminist perspectives. Washington Square, N.Y: New York University Press.

Lister, R. (2010). Understanding theories and concepts in social policy. Portland, OR; Briston: Policy Press.

Macintyre, C. (1999). The stakeholder society and the welfare state: Forward to the past. Contemporary Politics, 5(2), 121-135. doi:10.1080/13569779908449997

Magone, J. M. (2004). The developing place of Portugal in the European Union. New Brunswick, N.J: Transaction Publishers.

Mann, M. (1987). Ruling class strategies and citizenship. Sociology, 21(3), 339-354. doi:10.1177/0038038587021003003

Marshall, T. H. (1950). Citizenship and social class and other essays. London: Cambridge University Press. 
Marshall, T. H. (1970). Social policy in the twentieth century. London: Hutchinson University Library.

Matthews, B., \& Ross, L. (2010). Research methods: A practical guide for the social sciences (1st ed.). New York, NY: Pearson Longman.

Maxwell, J. A. (2005). Qualitative research design: An interactive approach (2nd ed.). Thousand Oaks, California: Sage Publications.

McBride, S. (2014). "In austerity we trust". In D. Baines \& McBride (Eds.), Orchestrating austerity: impacts and resistance (pp. 10-20). Halifax \& Winnipeg: Fernwood Publishing.

McBride, S. (2016). Constitutionalizing austerity: Taking the public out of public policy. Global Policy, 7(1), 5-14. doi:10.1111/1758-5899.12271

Merkel, W. (2014). Is capitalism compatible with democracy? Zeitschrift Für Vergleichende Politikwissenschaft, 8(2), 109-128. doi:10.1007/s12286-014-0199-4

Miller, D. (1995). Introduction. In D. Miller \& M. Walzer (Eds.), Pluralism, Justice, and Equality (pp.1-16). Oxford: Oxford University Press

Minas, C., Jacobson, D., Antoniou, E., \& McMullan, C. (2014). Welfare regime, welfare pillar and southern Europe. Journal of European Social Policy, 24(2), 135-149. doi: $10.1177 / 0958928713517917$

Mishra, R. (1993). Social policy in a post-modern world. In C. Jones (Ed.), New perspectives on the welfare state in Europe (pp. 16-35). London; New York: Routledge.

Mishra, R. (1999). Globalization and the welfare state. Cheltenham: Routledge.

Monteiro, A. (1998). Reforma da «segurança social»: um percurso de continuidades e descontinuidades. Intervenção Social, 17/18, 263-286. 
Monteiro, F., Tavares, J., Galtzer, M., \& Cardoso, A. (2003). Introduction. In F. Monteiro, J. Tavares, M. Galtzer and A. Cardoso (Eds.), Portugal: Strategic options in a European context (pp. 1-8). Lanham, Boulder, New York, Oxford: Lexington Books.

Moscovitch, A. (1981). The Canadian economy and inequality. In A. Moscovitch \& G. Drover (Eds.), Inequality: Essays on the political economy of social welfare (pp. 58-98). Toronto: University of Toronto Press.

Mozzicafreddo, J. (1991). O estado providência em Portugal: estratégias contraditórias. Sociologia, Problemas e Práticas, 12, 57-89.

Navarro, V. (1982). The crisis of the international capitalist order and its implications for the welfare state. Critical Social Policy, 2(1), 43-62.

Navarro, V., Schmitt, J., \& Astudillo, J. (2004). Is globalisation undermining the welfare state? Cambridge Journal of Economics, 28(1), 133-152. doi:10.1093/cje/28.1.133

Neuman, W. L. (2011). Social research methods: Qualitative and quantitative approaches (7th ed.). Boston: Allyn \& Bacon.

O’Brien, R., \& Zhang, F. (2014). Structural adjustment for the north. In D. Baines \& McBride (Eds.), Orchestrating austerity: impacts and resistance (pp. 21-33). Halifax \& Winnipeg: Fernwood Publishing.

O'Hara, M. (2013, Feb 26). Madgadela Sepúlveda: Austerity is devastating for the world's poorest. $\begin{array}{lll}\text { The Guardian. } & \text { Retrieved }\end{array}$ https://www.theguardian.com/society/2013/feb/26/magdalena-sepulveda-austerity$\underline{\text { devastating-worlds-poorest }}$

Organisation for Economic Co-operation and Development (2018a). Portugal general government deficit 1997-2008 (indicator). Retrieved from https://data.oecd.org/chart/5dlf 
Organisation for Economic Co-operation and Development (2018b). Portugal general government debt 1997-2008 (indicator). Retrieved from https://data.oecd.org/chart/5dlj

Organisation for Economic Co-operation and Development (2018c), Portugal unemployment rate 1997-2008 (indicator). Retrieved from https://data.oecd.org/chart/57VE

Organisation for Economic Co-operation and Development (2018d), Portugal public social spending 1997-2008 (indicator). Retrieved from https://data.oecd.org/chart/5e2S

Organisation for Economic Co-operation and Development (2018e), Portugal's general government spending 1997-2008 (indicator). $\quad$ Retrieved from https://data.oecd.org/chart/5e2N

Organisation for Economic Co-operation and Development (2018f), Portugal's household disposable income - net, annual growth rate (\%) (indicator). Retrieved from https://data.oecd.org/chart/5e5x

Organisation for Economic Co-operation and Development (2018g), Portugal's real GDPforecast - total, annual growth rate (\%) (indicator). Retrieved from https://data.oecd.org/chart/5e5B

Organisation for Economic Co-operation and Development (2018h), Portugal's short-term interest rates (indicator). Retrieved from https://data.oecd.org/chart/5e $8 \mathrm{j}$

Organisation for Economic Co-operation and Development (2018i), Portugal's long-term interest rates (indicator). Retrieved from https://data.oecd.org/chart/5e80

Organisation for Economic Co-operation and Development (2018j). Portugal general government deficit 2009-2015 (indicator). Retrieved from https://data.oecd.org/chart/5el2

Organisation for Economic Co-operation and Development (20181). Portugal general government debt 2009-2015 (indicator). Retrieved from https://data.oecd.org/chart/5ekX 
Organisation for Economic Co-operation and Development (2018m). Portugal unemployment rate 2009-2015 (indicator). Retrieved from https://data.oecd.org/chart/5eqd

Organisation for Economic Co-operation and Development (2018n). Portugal's tax revenue 20072015 (indicator). Retrieved from https://data.oecd.org/chart/5eqi

Organisation for Economic Co-operation and Development (20180), Portugal public social spending 2009-2015 (indicator). Retrieved from https://data.oecd.org/chart/5eCr

Organisation for Economic Co-operation and Development (2018p), Portugal public pension spending 2007-2013 (indicator). Retrieved from https://data.oecd.org/chart/5eCs

Organisation for Economic Co-operation and Development (2018q), Portugal public unemployment spending 2007-2013 (indicator). Retrieved from https://data.oecd.org/chart/5ew2

Organisation for Economic Co-operation and Development (2018r), Portugal family benefits public spending 2007-2013 (indicator). Retrieved from https://data.oecd.org/chart/5ewi

Organisation for Economic Co-operation and Development (2018s), Portugal public spending on incapacity 2007-2013 (indicator). Retrieved from https://data.oecd.org/chart/5exE

Organisation for Economic Co-operation and Development (2018t), Portugal public spending on labour markets 2007-2015 (indicator). Retrieved from https://data.oecd.org/chart/5exH

Organisation for Economic Co-operation and Development (2018u), Portugal general government spending 2009-2015 (indicator). Retrieved from https://data.oecd.org/chart/5eCL

Organisation for Economic Co-operation and Development (2018v), Portugal income inequality - Gini coefficient 2007-2015 (indicator). Retrieved from https://data.oecd.org/chart/5iWU

Organisation for Economic Co-operation and Development (2018x), Portugal poverty rate - total ratio 2007-2015 (indicator). Retrieved from $\underline{\text { https://data.oecd.org/chart/5iWV }}$ 
Palier, B. (2006). Beyond retrenchment: four problems in current welfare state research and one suggestion on how to overcome them. In C. Pierson \& F. G. Castles (Eds.), The welfare state reader, $2^{\text {nd }}$ ed. (pp. 358-374). Cambridge: Polity.

Palier, B. (2010a). Long goodbye to Bismarck?: The politics of welfare reform in continental Europe. Amsterdam: Amsterdam University Press.

Palier, B. (2010b). Continental western Europe. In F. G. Castles, S. Leibfried, J. Lewis, H. Obinger \& C. Pierson (Eds.), The Oxford handbook of the welfare state (pp. 601-615). Oxford: Oxford University Press.

Palier, B. (2013). Social policy paradigms, welfare state reforms and the crisis. Stato e Mercato, (97), 37-66.

Peters, J. (2011). The rise of finance and the decline of organised labour in the advanced capitalist countries. New Political Economy, 16(1), 73-99. doi:10.1080/13563461003789746

Pierson, C. (2007). Beyond the welfare state? The new political economy of welfare. University Park, PA: Pennsylvania State University Press.

Pierson, P. (2001). Coping with permanent austerity: welfare state restructuring in affluent democracies. In P. Pierson (Eds.), The new politics of the welfare state (pp. 410-456). Oxford: Oxford University Press.

Piketty, T. (2014). Capital in the twenty-first century. Cambridge Massachusetts: The Belknap Press of Harvard University Press.

Rawls, J. (2005). A theory of justice (Original ed.). Cambridge, Mass: Belknap Press.

Revi, B. (2014). T.H. Marshall and his critics: reappraising 'social citizenship' in the twenty-first century, Citizenship Studies, 18 (3-4), 452-464. doi: 10.1080/13621025.2014.905285 
Rhodes, M. (1996) Southern European welfare states: identity, problems and prospects for reform, South European Society and Politics, 1:3, 1-22, doi:10.1080/13608749608539480

Rodrigues, M. D. L., \& Silva, P. A. (2016). A constituição e as políticas públicas em Portugal. Sociologia, Problemas e Práticas, special issue, pp. 13-22. doi:10.7458/SPP2016NE10347 Royo, S. (2004). From authoritarianism to the European union: The europeanization of Portugal. Mediterranean Quarterly, 15(3), 95-129. 10.1215/10474552-15-3-95

Royo, S., \& Manuel, P. C. (2003). Some lessons from the fifteen anniversary of the accession of Portugal and Spain to the European Union. In P. C. Manuel \& S. Royo (2003), Spain and Portugal in the European Union: The first fifteen years (pp. 1-24). Portland;

London: Frank Cass \& Co. Ltd. doi :10.4324/9780203496619

Sandbeck, S., \& Schneider, E. (2014). From the sovereign debt crisis to authoritarian statism: Contradictions of the European state project. New Political Economy, 19(6), 847-871. doi:10.1080/13563467.2013.861411

Santos, B. S. (1984). A crise e a reconstituição do estado em Portugal (1974-1984). Revista Crítica de Ciências Sociais, 14, 7-29.

Sapir, A. (2006). Globalization and the reform of European social models. JCMS: Journal of Common Market Studies, 44(2), doi:369-390. 10.1111/j.1468-5965.2006.00627.x

Schafer, A. (2013). Liberalization, inequality and democracy's discontent. In W. Streeck \& A. Schafer (Eds.), Politics in the age of austerity (pp. 169-195). Cambridge, UK: Polity Press.

Schafer, A., \& Streeck, W. (2013). Introduction: politics in the age of austerity. In W. Streeck \& A. Schafer (Eds.), Politics in the age of austerity (pp. 1-25). Cambridge, UK: Polity Press.

Schroder, M. (2013). Integrating varieties of capitalism and welfare state research: A unified typology of capitalisms. Hampshire: Palgrave Macmillan. 
Scharpf, F. W. (2013). Monetary union, fiscal crisis and the disabling of democratic accountability. In W. Streeck \& A. Schafer (Eds.), Politics in the age of austerity (pp. 108-142). Cambridge, UK: Polity Press.

Soper, K. (1993). A theory of human needs. New Left Review, 197, 113-113.

Spicker, P. (1993). Needs as claims. Social Policy \& Administration, 27(1), 7-17. doi:10.1111/j.1467-9515.1993.tb00386.x

Spicker, P. (2006). Liberty, equality, fraternity. Bristol, UK: Policy Press.

Spicker, P. (2007). The idea of poverty. Bristol, UK: Policy.

Stephens, J. D. (2010). The social rights of citizenship. In F. G. Castles, S. Leibfried, J. Lewis, H. Obinger \& C. Pierson (Eds.), The Oxford handbook of the welfare state (pp. 511-525). Oxford: Oxford University Press.

Stiglitz, J. E. (2010). Freefall: America, free markets, and the sinking of the world economy. London: Allen Lane.

Streeck, W. (2013). The crisis in context: democratic capitalism and its contradictions. In W. Streeck \& A. Schafer (Eds.), Politics in the age of austerity (pp. 262-286). Cambridge, UK: Polity Press.

Streeck, W. (2014). Buying time: The delayed crisis of democratic capitalism. London, UK; Brooklyn, NY: Verso Books.

Streeck, W., \& Mertens, D. (2013). Public finance and the decline of state capacity in democratic capitalism. In W. Streeck \& A. Schafer (Eds.), Politics in the age of austerity (pp. 26-58). Cambridge, UK: Polity Press. 
Taylor-Gooby, P. (2004). New risks and social change. In P. Taylor-Gooby (Eds.), New risks, new welfare: The transformation of the European welfare state (pp. 1-28). Oxford: Oxford University Press.

Threlfall, M. (2007). The social dimension of the European union. Global Social Policy, 7(3), 271293. doi: $10.1177 / 1468018107082235$

Tribunal Constitucional (1976). Constitution of the Portuguese republic of 1976. Retrieved from http://www.tribunalconstitucional.pt/tc/content/files/crp/crp1976.pdf

Tribunal Constitucional (1982). Constitution of the Portuguese republic - first revision. Retrieved from http://www.tribunalconstitucional.pt/tc/content/files/crp/01revisao1982.pdf

Tribunal Constitucional (2005). Constitution of the Portuguese republic - seventh revision. Retrieved from http://www.tribunalconstitucional.pt/tc/conteudo/files/constituicaoingles.pdf

Tribunal Constitucional (2012). Ruling n. 353/2012. Retrieved from http://www.tribunalconstitucional.pt/tc/en/acordaos/20120353s.html

Tribunal Constitucional (2013a). Ruling n. 187/2013. Retrieved from http://www.tribunalconstitucional.pt/tc/en/acordaos/20130187s.html

Tribunal Constitucional (2013b). Ruling n. 862/2013. Retrieved from http://www.tribunalconstitucional.pt/tc/en/acordaos/20130862s.html

Tribunal Constitucional (2014). Ruling n. 413/2014. Retrieved from http://www.tribunalconstitucional.pt/tc/en/acordaos/20140413s.html

Turner, B. S. (1990). Outline of a theory of citizenship. Sociology, 24(2), 189-217. doi:10.1177/0038038590024002002 
Turner, B. S. (2001). The erosion of citizenship. The British Journal of Sociology, 52(2), 189-209. doi:10.1080/00071310120044944

United Nations (1948). Universal declaration of human rights. Retrieved from http://www.un.org/en/universal-declaration-human-rights/index.html

United Nations (2009). Report to the general assembly on the question of human rights and extreme poverty submitted by Magdalena Sepúlveda Carmona (A/64/279). Retrieved from https://documents-dds-ny.un.org/doc/UNDOC/GEN/N09/452/76/PDF/N0945276.pdf

United Nations Office of the High Commissioner for Human Rights (1966). International covenant on economic, social and cultural rights (ICESCR). Retrieved from https://www.ohchr.org/EN/ProfessionalInterest/Pages/CESCR.aspx

Vanhoonacker, S. (2012). The treaty of Amsterdam. In E. Jones, A. Menon \& S. Weatherill (Eds.), The Oxford handbook of the European Union (pp. 135-148). Oxford: Oxford University Press.

Varela, R. (2011). A persistência do conflito industrial organizado: greves em Portugal entre 1960 e 2008. Revista Mundos do Trabalho, 3(6) 151-175.

Varela, R. (2015). From anti-colonial revolutions to revolution in the metropolis. Critique, 43(2), 145-171. doi:10.1080/03017605.2015.1051791

Varela, R. (2016). State policies towards precarious work: Employment and unemployment in contemporary Portugal. International Review of Social History, 61, 263. doi:10.1017/S0020859016000444

Varela, R., \& Guedes, R. (2011). Sindicatos, neoliberalismo e estado social em Portugal (19742012). Praia Vermelha, 21(1) 71-88. 
Varela, R., \& Pereira, L. (2015). Segurança social, trabalho e estado em Portugal. Temporalis. 15(30), 21-52. doi: 10.22422/2238-1856.2015v15n30p21-52

Walzer, M. (1983). Spheres of justice: A defense of pluralism and equality. New York: Basic Books.

West, A. (2016). Education in schools. In P. Alcock, T. Haux, M. May \& S. Wright (Eds.), The student's companion to social policy (5 ${ }^{\text {th }}$ ed.) (pp. 365-371). Hoboken, NJ; Chichester, UK: John Wiley \& Sons.

Whyman, P., Mullen, A., \& Baimbridge, M. (2012a). The European social model. In P. Whyman, A. Mullen \& M. Baimbridge (2012), The political economy of the European social model (pp. 1-23). New York; Milton Park, Abingdon, Oxon: Routledge.

Whyman, P., Mullen, A., \& Baimbridge, M. (2012b). Neo-liberal Europe in the new world order (1985-2007) from the single market to the European constitution. In P. Whyman, A. Mullen \& M. Baimbridge (2012), The political economy of the European social model (pp. 62-83). New York; Milton Park, Abingdon, Oxon: Routledge.

White, S. (1997). What do egalitarians want?. In J. Frank (Ed.), Equality (pp. 59-82). London: Institute for Public Policy Research.

White, S. (2007). Equality. Malden, MA; Cambridge, UK: Polity Press.

Williams, F. (1989). Social policy - a critical introduction. Cambridge: Polity Press.

Williams, F. (2016). Critical thinking in social policy: The challenges of past, present and future. Social Policy \& Administration, 50(6), 628-647. doi:10.1111/spol.12253 
Williamson, J. (2004, January 13). The Washington consensus as policy prescription for development (A lecture in the series "Practitioners of Development" delivered at the World Bank). Washington, DC: The Peterson Institute for International Economics. Retrieved from https://piie.com/publications/papers/williamson0204.pdf

Williamson, J. (2008). A short history of the Washington consensus 1. In N. Serra \& J. E. Stiglitz (2008), The Washington consensus reconsidered: Towards a new global governance (pp. 12-30). Oxford, UK: Oxford University Press. doi: 10.1093/acprof:oso/9780199534081.003.0002

Wolff, R. D., \& Resnick, S. A. (2012). Contending economic theories: Neoclassical, Keynesian, and Marxian (Rev. ed.). Cambridge, Mass: MIT Press.

Wood, S. (2001). Labour market regimes under threat? Sources of continuity in Germany, Britain, and Sweden. In P. Pierson (Eds.), The new politics of the welfare state (pp. 368-409). Oxford: Oxford University Press.

World Health Organization (2013). Research for universal health coverage: World health report 2013. Retrieved from http://www.who.int/whr/2013/report/en/ 